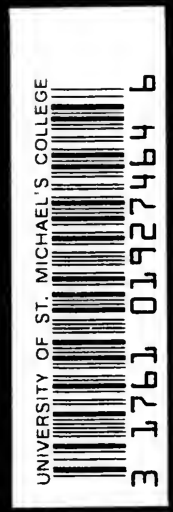


Digitized by the Internet Archive in 2008 with funding from

Microsoft Corporation

http://www.archive.org/details/fnelonarchbish00learuoft 
CHRISTIAN BIOGRAPHIES

BY

H. L. SIDNEY LEAR

FENELON

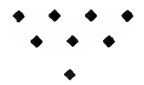




\title{
CHRISTIAN BIOGRAPHIES
}

BY

\author{
H. L. SIDNEY LEAR
}

New and uniform Editions. Crowun Svo. 3s. 6d. each.

Madame Louise de France, Daughter of Louis XV., known also as the Mother TÉRÈse DE S. AUgustin.

A Dominican Artist; a Sketch of the Life of the Rev. Père Besson, of the Order of St. Dominic.

Henri Perreyve. By A. Gratry, Prêtre de l'Oratoire, Professeur de Morale Evangélique à la Sorbonne, et Membre de l'Académie Française. Translated, by special permission. With Portrait.

S. Francis de Sales, Bishop and Prince of Geneva.

The Revival of Priestly Life in the Seventeenth Century in France. Charles de Condren-S. Philip Neri and Cardinal de Berulle-S. Vincent de Paul-Saint Sulpice and Jean Jacques Olier.

A Christian Painter of the Nineteenth Century; being the Life of Hippolyte Flandrin.

Bossuet and his Contemporaries.

Fénelon, Archbishop of Cambrai.

\section{Ríníngtang}

- LONDON, OXFORD, AND CAMBRIDGE 


\section{F É N E L O N}

\section{Grchbisbop of đambraí}

A BIOGRAPHICAL SKETCH

By the Author of

"Life of Bossuet," "Life of S. Francis de Sales" E'TC. ETC.

H.L. Sidney Lear

RIVINGTONS

WATERLOO PLACE, LONDON

Drford, and Tambridge

MDCCCLXXVII

$18 \% ?$

[New Edition] 
[B-13I] 


\section{周eface}

T $T$ has not been possible, in writing this Life of 1 Fénelon, to steer clear of the repetition of certain matters dwelt on in the Life of Bossuet; while, on the other hand, some subjects have been rather glanced at than dwelt upon, because they have been already handled in connection with the Bishop of Meaux. The immense amount of correspondence and of Mémoires, or contemporary records, is a veritable $\mathrm{em}$ barras des richesses in writing on this period of Church History, and I feel that this sketch, written amid much interruption and hindrance, is most imperfect and unworthy of its great subject. It may, however, prove suggestive, and lead English people to draw for themselves from that deep well of interesting matter whence my small buckets have come up. The Père Querbœuf's Life of Fénelon, De Ramsai's quaint 
little old book; Cardinal de Bausset's Histoire, Saint Simon's and de la Baumelle's voluminous Mémoires, D'Agtıesseau's works, together with Fénelon's own enormous correspondence and Bossuet's, are the chief authorities I have consulted. Fénelon's letters are of various kinds,-political, social, controversial, spiritual. Of these latter a volume is in the press, containing such as were addressed to men only, to be followed by another written to the women under his direction, chiefly to ladies living at Court or in high worldly position. His letters are the fullest, almost necessary supplement to his Life, being, as they are, so full of the inmost character of the writer.

October, 1876. 


\section{CONTENTS.}

\section{CHAPTER I.}

Birth-Antoine de Fénelon-Saint Sulpice-Tronson-

Parochial Work-Proposed Mission to Greece-Bishop of Sarlat's Opposition-Nouvelles Catholiques-De Harlay's Spite-Priory of Carenac-Letters to Mme. de Laval-Death of the Marquis de Fénelon-De Beauvilliers' Family-Traité de l'Éducation des FillesOther Works-Missions of Poitou and SaintongeLetters to the Marquis de Seignelai-To BossuetProposed Preferment-De Harlay frustrates it . . I

\section{CHAPTER II.}

The Duc de Bourgogne-Duc de Beauvilliers GovernorFénelon appointed Preceptor-Letters from Bossuet and Tronson-Colleagues-Saint Simon's Description of Fénelon, and D'Aguesseau's-Character of the Duc de Bourgogne-Fénelon's Treatment of him-Le Fantasque-A Medal-Literary Education-The Abbé Fleury-The Duke's Fiery Temper-Religious Im- 
pressions-Dialogues des Morts-Fénelon's Restricted

Means-Mme. de Maintenon-Correspondence with her .

\section{CHAPTER III.}

Molinos and Quietism-Mme. Guyon-Père la CombeMoyen Court-Fénelon's Introduction to Mme. GuyonAbbé Godet-des-Marais-Mme. de Maisonfort-Letter from Bourdaloue-Increasing Perplexities about Mme. Guyon-Bossuet consulted-Conference of Issy-Fénelon appointed Archbishop of Cambrai-Resigns the Abbey of St. Valery-His Consecration-Death of de Harlay-De Noailles Archbishop of Paris-Arrest of Mme. Guyon-Letter from Fénelon to Tronson-From de Beauvilliers to Tronson-Fénelon to Mme. de Maintenon-Mme. Guyon signs an Act of SubmissionIs sent to the Bastille--Release and Death at Blois .

\section{CHAPTER IV.}

Bossuet's Attacks on Mysticism-Maximes des SaintsLetter from Fénelon to the Archbishop of Paris-The Maximes submitted to Dr. Pirot and others-Correspondence-The King's Prejudice-Fire at CambraiLetter from de Brisacier-From de Chanterac-De Rancé-Letter from de Noailles to Mme. de Maintenon -Perplexities-Cabals at Court-Saint Cyr-Appeal to 
the Pope-Fénelon's Letter to Innocent XII.-Disturbance at Home - Bossuet's Antagonism - Fénelon's Letter to de Noailles-Proposed Conference-Fénelon's Conditions-Asks Leave to go to Rome himself - The King refuses-Banished to Cambrai-Letter to Mme. deMaintenon-Farewell to Tronson-Letter to de Brisacier-Party against Fénelon-Duc de Bourgogne's Affection-Attack upon de Beauvilliers-Letters to him from Fénelon-To Mme. de Gamaches-Work at Cambrai-D'Aguesseau's Account of the Contest-The Pope's Comments - De Chanterac appointed as Fénelon's Representative at Rome-Cardinal de Bouillon-The Abbé Bossuet-Correspondence from Rome-De Chanterac to de Langeron-Declaration of the Opposing Prelates-Various Opinions concerning Fénelon's Book-Duc de Bourgogne's Marriage-De Noailles' Pastoral Instruction-Louis XIV. dismisses all Fénelon's Friends-Letters to de Chanterac-Examination of the Maximes-Rélation sur le QuiétismeIntrigues at Rome-Fénelon's Answer-Excitement in Rome-Sympathy of the Pope-De Chanterac's Letters - Counter Efforts in Paris-The Abbé Bossuet-Reference to the Sacred College-Letter from Fénelon to Mme. de Maintenon-Doctors of Sorbonne-Fénelon's Name erased from the Royal Household-Pressure put upon the Pope-The Cardinals in Conclave-Extraordinary Congregation-Cardinal Casanata-Efforts of the Pope on behalf of Fénelon-Final Decree-De Chante. rac's announcement of it to Fénelon-The Tidings reach Cambrai-Fénelon's Reception thereof-His LettersFénelon's Mandement-The King's Conduct-D'Aguesseau's Criticisms-Feeling at Rome-Papal Brief- 
Metropolitan Assemblies in France-Assembly of Paris-Bishop of Saint Omer's Offensive ConductD'Aguesseau's Discours-Private Letters from Fénelon -Question of Reconciliation with Bossuet . . . I33

\section{CHAPTER V.}

Court of France-Fénelon's Enemies and Friends-Mme. de Maintenon - Cardinal Archbishop - Bishop of Chartres-Télémaque-MS. stolen and publishedThe King's Displeasure-Correspondence with the Duc de Bourgogne-Spiritual Counsel to him-The Example of Saint Louis-Respect shown to Fénelon by the Allies, Prince Eugene, etc. - Strangers attracted to Cambrai -Fénelon in the Hospitals, etc. - Manner of Daily Life -Abbé Le-Dieu's Visit to Cambrai, and Details of the Archbishop's Life there-The Palace - SeminaryFénelon's Personal Intercourse with his ClergyReligious Houses-Unremitting Labour-PreachingDialogues sur L'Eloquence-Correspondence-Letters to de Beauvilliers and de Chevreuse-Visit of the Duc de Bourgogne to Cambrai-Campaign in Flanders-A Second Meeting-Fénelon's Anxiety about the Duc de Bourgogne-Advice to him-Letters from and to himDuc de Vendôme-Battle of Oudenarde-Cabal against de Bourgogne-The Duke and the Army-LettersTrue Popularity-Difficulties at Court-Discretion in Strictness-Theatres-The Duke' of Marlborough's Generosity-Fénelon's Letters to his Nephew the Marquis de Fénelon-To the Abbé de Beaumont-To the Abbé de 
Salignac-Visit to the Camp-Mme. de Chevreuse-The Elector of Cologne-Lobos and Alexis-Accusations of Quietism-Correspondence

\section{CHAPTER VI.}

Death of the Emperor Joseph-And of the Dauphin-Succession of the Duc de Bourgogne-Counsel to himChange of Court Feeling-Letters to de BeauvilliersProspects for the Future-Projet pour le Présent-IIlness and Death of the Dauphine-Death of the Dauphin -Of the Duc de Brétagne-Fénelon's Letters-His Intense Grief-The Dauphin's Papers-Directions pour la Conscience d'un Roi-Letter to the Père MartineauThe Duc d'Orléans-De Ramsai-CorrespondenceBull Vineam Domini-Death of de Langeron-Of de Chevreuse-Letters to the Duc de Chaulnes-Characters of his Children-Death of de Beauvilliers-Letters to the Duchesse-Fénelon's Failing Health-Letter to the Secretary of State-Question of a Coadjutor-Assembly of Clergy-A Carriage Accident-Last LettersFénelon taken Ill-Dying Hours-Last SacramentsLetter to the King's Confessor-The Last NightDeath-Fénelon's Will-Regrets at Rome-The King

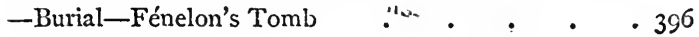




$$
-
$$




\section{CHAPTER I.}

RANÇOIS DE SALIGNAC DE LAMOTHE
FÉNELON,-perhaps the most attractive and loveable (and if not the most saintly, he was certainly inferior to none in the beauty of holiness) among the many stars which shone in the Church's sky during the seventeenth century,-is one of those rare persons of whom it is difficult to speak withcut falling into what seems unworthy of him-mere panegyric. His great gifts and exceeding graciousness and charm meet one at every turn, and in very truth his faults are not easy to discover, even to the eye of criticism. But nothing in the way of biography is so offensive to the reader and so degrading to his subject as flattery and laudation; let us therefore look in simple truth at the facts of the great Archbishop's life, to be followed in contemporaneous history, and in his own writings, and leave the lights and shadows alike to come forth in all truthfulness and simplicity.

The man whose name was to become so lovingly 
familiar to the whole Church henceforward sprang from a noble family in France. Salignac (or Salagnac) was one of the first châtellenies of Périgord, and created a Barony in 1460 , before which date the name was already distinguished. A de Salagnac was Bishop of Comminges in 1300 , and two Archbishops of Bordeaux sprang from the same family in 1296 and 1361 . Later on, six Bishops of Sarlat were de Salignacs; while in the world the name was no less well known. Raymond de Salagnac, Seigneur de Lamothe Fénelon, the Seneschal of Quercy and Périgord, and Lieutenant-Governor of Guyenne, fought for the Dauphin, afterwards Charles VII. : his son was Governor of Périgord and Limousin under Jean d'Albret, King of Navarre ; and a certain Géraud de Salignac was one of Henri IV.'s governors. Bertrand de Salignac, great-great-uncle to the Archbishop of Cambrai, was among the defenders of Metz when it was besieged by the Emperor Charles V., and many other of his warrior ancestors might be enumerated. The pedigree of Lamothe Fénelon contains many of the best names in France:-TalleyrandChalais, de la Tremouille, de Gontaut-Biron, de Durfort, de Buffière, de Caumont, de la Roche-Aymon, de Cardrillac, de Montausier, de Coussal, D'Aubusson, de Monthéron, de Montmorenci-Laval, etc. etc.

Pons de Salignac, father of the future Archbishop of Cambrai, was first married to Isabelle d'Esparbès 
de Lussan, a daughter of the Maréchal d'Aubeterre, and his sons by this marriage had already joined the army when he married a second wife-Louise de la Cropte de Saint-Abre, who gave birth to François, August 6, I65I, at the Château de Fénelon, about three miles from Sarlat in Périgord. $\mathrm{He}$ was a delicate child, of a fragile and sensitive temperament, and the idol of his old father, who kept him at home till he was twelve years old, giving him "a simple Christian education, devoid of anything remarkable, and probably all the better for that," as one of his biographers $^{x}$ remarks. However, the foundation of Fénelon's future exquisite style and finished classical acquirements seems to have been laid in the course of this simple home education; for, after being a short time at the College of Cahors, his uncle, the Marquis Antoine de Fénelon, found him so advanced in his education as to make a removal to Paris desirable. Apparently the old Count Pons de Salignac must have died about this time, as henceforth we hear nothing of him, but find the Marquis Antoine taking the part of father towards his nephew, whom he removed to the Collége du Plessis, then under the rule of M. Gobinet, a first-rate Principal. There François speedily distinguished himself as a scholar, and also as possessing the gift of eloquence for which

` Père Querbeuf. 
he became so conspicuous later. Like Bossuet, he was put forward at fifteen to preach to an admiring audience; and very soon his personal attractions, captivating manner, and advanced scholarship, made the Marquis de Fénelon anxious lest his young nephew should be spoiled by the flattery and adoration of a world with which he was well acquainted, and knew how to gauge.

This uncle was a sufficiently remarkable person to require some few words of description. The Grand Condé described him once as being "equally at home in society, war, and the council chamber;"-and he had distinguished himself in the service so conspicuously, that he dared to take a step which would have sunk many men irreparably in the world's esteem at that period. It came about thus. The Marquis, becoming deeply impressed with the truths and realities of Christianity, put himself under the spiritual guidance of M. Olier, the celebrated founder of Saint Sulpice. M. Olier was at that time earnestly trying to check the practice of duelling, which had been repressed for a while by the strong hand of Cardinal Richelieu, but which had broken out anew with a sort of extravagant frenzy since the death of that minister. M. Olier wanted to form an association of gentlemen whose courage was past impeachment, and who should bind themselves by oath neither to accept any 
challenge nor to act the part of second in any duel; and he could think of no one whose reputation was more firmly established both in court and camp than the Marquis de Fénelon, who accordingly undertook the post of President of the association. No one was to be admitted into it at first whose military repute did not stand high; for they well knew how strong the force of prejudice was : in proof of which-soon after a company of brave soldiers had solemnly signed their agreement in the chapel of the Seminary of Saint Sulpice, before a large assembly of noble witnesses (Whit Suntide, r65 I) - the Grand Condé himself could not help saying to the Marquis, that but for his personal knowledge of that officer's valour, he should have been frightened to see him "break such a glass."

I The declaration signed by these officers was worded as follows :- "Les soussignés font par le présent écrit déclaration publique et protestation solennelle de refuser toutes sortes d'appel, et de ne se battre jamais en duel pour quelque cause que ce puisse être, et de rendre toute sorte de témoignages de la détestation qu'ils font du duel, comme d'une chose tout-à-fait contraire à la raison, au bien, et aux lois de l'état, et incompatible avec le salut et la réligion chrétienne; sans pourtant renoncer au droit de repousser par toutes les voies légitimes les injures qui leur seront faites, autant que leur profession et leur naissance les y obligent : étant aussi toujours prêts de leur part d'éclairer de bonne foi ceux qui croiroient avoir lieu de ressentiment contre eux, et de n'en donner sujet à personne." This act, when signed, was authorised and registered by the Tribunal des Maréchaux des France. 
The Marquis de Fénelon was certainly no flatterer, if we may judge by a saying of his to M. de Harlay, the fashionable and profligate Archbishop of Paris, on his appointment:- "It is well, Monseigneur," the soldier remarked by way of congratulation, "to remember the difference between the day when all France is complimenting you on your nomination and the day of your death, when you will have to give account to God for the way in which you have used it!" He always held the like straightforward language to all connected with him; and was wont to tell his only son-like himself a soldierthat life and death did not depend upon the enemy, but upon Him Who rules both; adding, that there was no better manner of death than to die for his King. ${ }^{x}$

The Marquis lost this only son, who was killed at the siege of Candia in 1669 ; and from that time he was devoted to his only daughter (who married the Marquis de Montmorenci-Laval) and to his nephew François. The latter he moved, seemingly about this time, to the Seminary of Saint Sulpice, then governed by the saintly Tronson, who thenceforward was always Fénelon's dearest friend and counsellor. Part of a manuscript letter from the student to his uncle shows

s Voltaire, quoting these words, remarks, that it must be confessed an army of likeminded men would be invincible. 
what was the character of that friendship from the beginning :-

"I very earnestly wish," he says, "that I could give you a detailed account of what passes between M. Tronson and me, but, indeed, I hardly know what to tell ; for, great as is my freedom and open-heartedness with you, I must confess, without any fear of making you jealous, that I am still more unreserved with M. Tronson, and that I could not easily describe the close way in which I feel bound to him. Assuredly, if you could hear our conversations, and the ease with which I lay bare my heart to him, and with which he teaches me to know God, you would not know your pupil, and you would see that God has very marvellously helped on the work which you began. My health does not improve, which would be a great trial to me if I were not learning how to comfort myself." $x$

The Congregation of Saint Sulpice had at this time a large missionary establishment in Canada, to which sundry students from the Seminary had gone; and it seems that François desired to follow in their steps, and become a missionary. Another of his uncles, the Bishop of Sarlat, was very much opposed to this step, as we may gather from the following letters addressed to him by the venerable Director of the Seminary:-

${ }^{I}$ Fénelon, Correspondence, edit. Le Clerc, vol. ii. p. 4. 
To the Bishop of Sarlat.

"February 1667.

"Monseigneur,-I have no doubt but that your nephew's intentions were a great surprise to you. Your claims of all kinds upon him, and the very reasonable and pious wishes you feel on behalf of your diocese, most naturally excite your regrets concerning him. I can assure you, Monseigneur, that I could most heartily have wished that he should conform to your intentions, and that I should gladly have seen him devote himself to prepare to serve under a prelate to whose service I should rejoice to give myself, were it possible. But his resolution is of that kind, that I do not know what more I can do, after what I said to him before he left me. I believe that your brother the Marquis knows how little share we have had in his plans. I have always endeavoured to dissuade him from them, and have urged him repeatedly to do nothing in a hurry: I have told him plainly that, if he can calm his longings and be quiet, he might, by going on with his studies and spiritual training, become more fit to work usefully hereafter for the Church. In short, Monseigneur, I have tested his resolutions by putting everything before him which I thought most likely to move him; but finding, after all. that his mind was equally set, and 
his intentions equally unselfish, I could do no more; both because persuasion seemed useless, and because I did not feel justified in doing violence to his strong feelings. This, Monseigneur, is what I feel bound to tell you concerning a matter in which you can speak with authority, but in which I perceive too confirmed a resolution to have much hope of change. I only say this in order to explain his conduct and mine, to comply with the wishes expressed in your letter, and to assure you that I am now and ever, Monseigneur, your humble and obedient servant,

"Louis Tronson."

"P.S.-One word more as to our silence concerning this matter, which I have learnt, since writing the above, has appeared wrong to you.

"First, I must observe that we are not in the habit of speaking about those whom we direct or confess;we simply give advice on the subjects they lay before us, and it is through no want of respect to those under whose authority they are if we are silent about matters which we have no right to publish. We take it for granted that they will not fail in their duty to such persons.

"Secondly, Monseigneur, I must say that I did not feel bound to write to you on this subject, having entered into a full explanation of my mind concern-

'Correspondence, vol. ii. p. 287. 
ing it with your nephew in the presence of your brother the Marquis. As he knew my whole opinion, I could not doubt but that he would give you full information, and I believed that there was no surer or safer way of putting you in possession of everything.

"Such, Monseigneur, were the chief reasons for my silence concerning your nephew's proposed journey. Now that he has spoken for himself, you will judge for yourself of his vocation. His strong persisting inclination, the firmness of his resolution, and the purity of his intentions, have made me feel that they deserved attention, and lead me to give you as exact a report as may be of our action in the matter."

Fénelon went, as Tronson's letter states, to see his uncle and plead his own cause; but in vain. The Bishop looked upon his nephew's delicacy as an insuperable difficulty, and was glad, evidently, to have so good a reason to give for retaining him in France. The gentle spirit of obedience, which was to be so remarkably displayed later on by the Archbishop of Cambrai, was shown on this occasion; and, though disappointed, François returned to Saint Sulpice, and devoted himself perseveringly to study, until he was ordained. After receiving Holy Orders, he continued to work in the parish of Saint Sulpice, attached to the Congregation founded by M. Olier,-a good 
school for parochial work and for apostolic selfdenial. The miserable, depraved state of that part of Paris has been already described, ${ }^{x}$ and the admirable system introduced by M. Olier for at once relieving that and training his associates in the exercise of their ministerial functions. M. Languet was the Curé at the time of Fénelon's ordination,- -he was said to distribute more than a million in alms yearly, while his own room was furnished with nothing more than a coarse bed and two straw chairs, - and under his guidance Fénelon became acquainted with the needs and sufferings of the poor, the sick and the sinful,-a knowledge of infinite value to him throughout his future life, although it left, not unnaturally, a somewhat mournful impression upon a mind so sensitive as his was. $\mathrm{He}$ was also trained at Saint Sulpice as a preacher, and his simple, earnest manner was very attractive among his poor listeners.

In 1674 , the Bishop of Sarlat summoned his nephew to 'that diocese, and probably intended to keep him there, but the missionary spirit was by no means quenched in Fénelon, and he soon turned his thoughts again to mission work, though no longer to America. This time it was

"Immortal Greece, dear land of glorious lays,"

I "Saint Sulpice and Jean Jacques Olier," Priestly Life in France, p. 288. 
which attracted him; and a manuscript letter, dated Sarlat, Oct. 9, 1675, and apparently addressed to the Duc de Beauvilliers, tells the history of the period :-

"Various trifling occurrences have hitherto delayed my return to Paris, but at last, Monseigneur, I am about to start, and I shall make good speed! But I am meditating a more distant journey. The whole of Greece lies open before me; - the Sultan is drawing back, Peloponnesus already breathes freely, and the Church of Corinth will revive and once more hear the Apostle's voice. I fancy myself transported to those glorious scenes, amid those precious ruins, gathering up the very spirit of antiquity from their venerable remains. I long to seek out that Areopagus whence S. Paul proclaimed the Unknown God to heathen sages. Then, after what is sacred, come profaner memories, and I do not disdain to descend to the Piræus, and Socrates planning his Republic. I ascend the twin summits of Parnassus, I gather the Delphic laurels, and revel in the charms of Tempé. When will Turkish and Persian blood mingle on the plains of Marathon, and leave Greece to religion, philosophy, and art, whose true home she is?

$$
\text { ... 'Arva beata }
$$

Petamus arva, divites et insulas.' ${ }^{\text {I }}$

Neither will I forget thee, $O$ island consecrated by s Hor. Epod. xvi. 41, 42. 
the heavenly visions of the Beloved Disciple! O blessed Patmos, I will hasten to kiss the footprints left on thee by the Apostle, and to imagine Heaven opened to my gaze! to burn with indignation at the false prophet who presumed to interpret the oracles of the true; and to bless the Almighty, Who, instead of casting down the Church, like Babylon, has chained the dragon, and caused her to be victorious. Already I see schism healed, East and West reunited, Asia waking to the light after her long sleep; the Holy Land, once trodden by our Saviour's Feet and watered with His Blood, delivered from profaners and filled with new glory; the children of Abraham, more numerous than the stars, now scattered over the face of the earth, gathered from all her quarters to confess the Christ they crucified, and to rise again with Him. But enough of all this, Monseigneur. You will be glad to know that this is my last letter, and the end of my enthusiasm, which may perhaps be troublesome. Forgive me on the plea of my need to pour it out to you from afar, until I can do so by word of mouth." I

Probably the Bishop of Sarlat acted with some diplomacy in this case, not refusing his consent to his nephew's departure, but rather working on his affectionate and grateful nature, which shrank from

- Correspondence, vol. ii. p. 29 I. 
giving pain to any, especially to an aged and respected uncle. So, in spite of his enthusiasm, Fénelon gave up his expedition to the Levant; and the next thing we hear of him is his appointment by the Archbishop of Paris as Superior of the Community called the Nouvelles Catholiques. This Community had been founded in 1634 by Archbishop Gondi, as a protection for women converted from Protestantism, and as a means of propagating Church teaching among those yet unconverted. Marshal Turenne had taken a great interest in this Community, and Louis XIV. himself looked favourably upon it ; so that, in appointing so young a man as the Abbé Fénelon as its Superior, Monseigneur de Harlay must have felt that he was bringing him to the front in a very marked way. But it was a marked characteristic of Fénelon's never to show any elation or self-satisfaction in success, or depression under the heavy reverses which were heaped upon him later; and now he assumed his new position quietly enough, leaving Saint Sulpice, and taking up his abode with his uncle the Marquis de Fénelon in the Abbey of Saint Germain des Prés, and giving hims lf up as entirely to his work as if he had not been brought into so much closer proximity to the Court and the world of Paris. $\mathrm{He}$ avoided general society, only living intimately with some few chosen triends,--his beloved director Tronson, the 
Duc de Beauvilliers, Langéron, Fleury, and Bossuet, with whom he now became acquainted, and with whom he shared the celebrated gatherings in the Allée des Philosophes at Versailles. ${ }^{x}$ At this time Fénelon was a special favourite with de Harlay, who liked rank, good looks, and brilliant powers, all of which the young Abbé possessed; and he seems to have intended to use him as a kind of counter attraction to Bossuet, whose influence both in the Church and the world was becoming sufficiently pronounced to excite considerable jealousy in the ambitious, secular-minded Archbishop. But Fénelon was not a man to be won by flattery, neither had he the slightest inclination to set himself up as a leader in opposition to his elder friend, whose solidity and deep learning had made a great impression on him : he frequented Bossuet's society more and more, and the Archbishop's less, until de Harlay's favour was turned into a jealous spite, which he did not restrain, -on one occasion publicly making the severe speech, "It seems, M. l'Abbé, that you wish to be forgotten, and you shall be!"

It was all very well for Monseigneur de Harlay to vent his wrath thus, but Fénelon was a far greater man than himself, and it did not rest with him to create or set aside his reputation. Meanwhile the Arch-

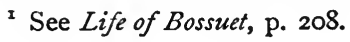


bishop carefully refrained from giving him any appointment which would supply him with funds; and until r68 I Fénelon continued entirely dependent on his uncle the Marquis for everything. In this year the Bishop of Sarlat resigned the Priory of Carenac, at Quercy on the Dordogne, in favour of his nephew; and this small benefice, producing between three and four thousand livres yearly, was the only revenue Fénelon possessed for many years. A playful letter written to his cousin, the Marquise de Laval, gives an account of his entry at Carenac:-

“May 22, 168I.

"Verily, Madame, doubt it not, I am a man who is destined to pomp and magnificence! You remember what a reception your people gave me at Bellac, and now I will tell you how I have been honoured here. The noblesse, represented by $M$. de Rouffillac, the clergy by M. Bosé the Curé, the monastic body by M. Rigaudie the Prior, and the tiers-état by all the farmers round about, came out to Sarlat to pay their respects. Then I marched majestically, accompanied by all these deputies, until I arrived at the port of Carenac, where I found the quay lined with crowds of people. Two boats filled with the élite of the townspeople approached, and at the same moment I perceived that, by a gallant manœuvre, the stalwart 
troops of the district, who had lain in wait in a corner of the island, came forth in battle array to salute me with repeated discharges of musketry. The air was thick with smoke, and one was deafened with reports of gunpowder. My fiery steed, filled with ardour, tried to plunge into the water, but I being less ardent, preferred dismounting. Then the drums added to the clatter. I crossed the Dordogne, which was covered with boats, and on the shore the whole body of venerable monks were solemnly waiting for me. Their harangue was full of sublime laudation; my reply was at once imposing and tender! The vast crowd opened to let me pass, all eyes eager to read in mine what would happen. So I progressed with slow and measured steps, to indulge the public curiosity, up to the castle, while a confused din of joy burst from a thousand throats, every one crying out, 'He will be the delight of the people!' When I reached the gate, the consul's harangue was spoken by the royal orator. The very name will convey to you the vision of all that is most pompous and eloquent; who can describe the grace of his speech! He compared me to the sun, then soon after I was the moon, and in course of time all the brightest planets had the honour of being likened to me; thence we got on to the elements and meteors, and made a happy ending somewhere in the beginning of the world! By 
that time the sun had set, and in order to preserve the parallel between it and myself, I went to my room, and to bed likewise!"

A few days later we find another cheerful letter written to Mme. de Laval (who was as his sister-the only one he ever knew) from Issigeac, his uncle's country house:-

"It is not every day that one has time and topics for the sublime! So do not be surprised if you do not get a fresh series of my adventures every week; days of pomp and triumph are not always occurring! My reception at Carenac was not followed by any memorable event, and my reign has been so peaceful as to afford no materials for history. I left that place to join my uncle here, and passed through Sarlat on the way, stopping a day to hear a famous cause which was being argued by the Ciceros of the town. The pleaders began with the creation of the world, and went straight on through the deluge to the matter in question. That question was how to feed some children who had nothing to eat. The orator who had undertaken to press the calls of their appetite upon the judges very judiciously mixed these up with the most stringent laws of the Code, and Ovid's Metamorphoses with solemn passages of Holy Scripture; and this most artistic medley was greatly applauded by ${ }^{2}$ Corrcspondence, vol. ii. p. 9. 
people of good taste. Everybody supposed that the children would get well fed, and that such eloquence would insure their dinner for ever. But so capricious is fortune, that though the lawyer got plenty of praise, the poor children got no food. The cause was postponed,-in other words, the unlucky brats were left fasting, while the judges gravely suspended proceedings in order that they might dine; so I too took my departure, and came here to Monseigneur with your letters. I arrived almost incognito, to avoid the cost of a reception, and took the place by surprise about seven in the morning,-so I have no ceremonial or harangue wherewith to edify you." ${ }_{1}$....

These were playtimes. Fénelon was not long absent from Paris, where for ten years he devoted himself to his work in connection with the Community of which he was Superior, to study, and to the society of the few learned and pious friends with whom he chiefly lived. Foremost among these was his uncle, who however died, October 8,1683 , and it was as the loss of a father to Fénelon. The Duc de Beauvilliers was another intimate friend, and it was at the request of the Duchess, who had no less than eight daughters, that the Abbé Fénelon (who had by this time become a spiritual guide as well as a dear friend in the family) wrote his first book, which has 
been so celebrated ever since-the Traité de l'Education des Filles. This work on education has held its high position among all on the same subject unvaryingly; it has been praised and recommended by all religionists, and quoted incessantly by writers of the most different type, and unquestionably it must have had great weight in bringing about the appointment of the writer as Preceptor to the little Duc de Bourgogne. No one could read these thoughtful, carefully worked out pages without feeling that education was a work for which he was eminently fitted; and those who knew Fénelon best would be most certain that with him to know a thing was to do it;-he was no mere inventor of theories.

The Education des Filles purports, as it title implies, specially to treat of girls, but the main substance of the treatise applies as much to boys; for, after all, the training, religious and intellectual, of little children must be the same for both, and it is to this foundation that the Abbé Fénelon devotes most of his pages. At the same time he does not fail to anticipate the question which occupies so much attention in our day, of what we call the "rights of women." Fénelon would give them their truest, best rights. "The world," he says, "is no mere phantasmagoria, but an assemblage of families, and what police can rule these with such precision as women, who, in addition to 
their natural authority and position in their households, have the further advantage of being born with a disposition to carefulness and detail, who are industrious, winning, and persuasive. . . . These, then, are the rightful occupations of women, which are no less important to the public than those of men,- - a household to rule, a husband to bless, children to bring up well. Add to this, that virtue is set before women as before men: and, not to speak of the good or evil they may work for the public, they form one half of the human race, bought with the Blood of Jesus Christ, and destined to eternal life." x

Fénelon would give the young girl useful, solid tastes, which should fill her mind with real interests and prevent idle curiosity; and also avert the danger of romance-reading, which "fosters unreality, for the grandiose language of such heroes spoils women for their everyday life. All those pompous sentiments, and exaggerated passions, and fanciful adventures, have little or nothing to do with the real actions and motives which govern the world and rule its affairs; and the poor child, breathing the atmosphere of tenderness and marvel with which her books are filled, is amazed not to find the counterparts of her heroes in real life, . . and she is dis-

${ }^{x}$ Euvres, edit. Dufour, vol. xi. p. II4. 
gusted at the descent from such heights to the necessary details of her home."

One evil against which Fénelon would guard his pupils is superstition. "Certainly it is to be feared among women," he says, "but nothing so tends to avert or cure it as a solid teaching. And this teaching, though it should be within due limits, and include no mere learned study, should be more extended than people ordinarily think. Many a person thinks himself well informed who is far otherwise, whose ignorance indeed is so great that he is not able to perceive how much he has to learn in order to understand the principles of Christianity. It should be a first rule never to admit anything either as a matter of belief or as a religious exercise which is not drawn from the Gospel or authorised by the permanent sanction of the Church.... Accustom your daughters, who are naturally credulous, not to accept certain unauthorised narratives, or to adopt certain devotions which indiscreet zeal has introduced, unsanctioned by the Church. The best teaching in such matters is less by means of criticism concerning things which are often well and piously intended, than by showing, without passing any condemnation, that they have no solid basis." 2

It is wonderful how much knowledge of detail

$$
\text { ' Euvres, vol. xi. p. 120. } \quad \text { Ibid. p. I8 } 3 \text {. }
$$


Fénelon shows in this book both of the needs and characteristics of little children, and of the special wants and infirmities of women; and one is tempted to marvel where, at this period of his life, he could have gained so much insight into both. His remarks upon the training which will make a woman a good economist, yet thoroughly liberal, "not priding herself on saving a candle, while letting herself be grossly cheated on a large scale;" and upon the charm of order, and of knowing where everything is and how to lay the hand upon it when wanted, might be written in capitals and hung up in every household among us !

Education was not the only subject on which Fénelon wrote at this time. An elaborate criticism on Malebranche's Treatise of Nature and Grace, with marginal notes by Bossuet, which was not published, and the Traite du Ministere des Pasteurs, were both produced during these comparatively quiet years. The latter work treats, as its name implies, of the authority of the Priesthood and its derivation. Its purport may be gathered from the opening sentence :

"If, as we affirm, and as experience must ever prove to all humble minds, ordinary men cannot decide for themselves as to the detail of dogmas, could the Divine Wisdom have taken any surer means of keeping them from error than by giving 
them an external authority, which, deriving its origin from Jesus Christ Himself and His Apostles, should set forth an uninterrupted succession of pastors ?"1

But Fénelon's literary labours were about to be laid aside for a different kind of work, for which, however, they had doubtless greatly tended to fit him. In Oct. 1685 , Louis XIV. revoked the Edict of Nantes, and the religious troubles which disturbed France in consequence are a matter of history. Bossuet, whose counsels at this period always leant to the side of gentleness, suggested the Abbé de Fénelon as a suitable missioner for the districts of Poitou and Saintonge, where great confusion and irritation prevailed, and where a tender, judicious hand only could hope to guide the reins. In consequence of this suggestion the King sent for Fénelon, and after a conference of some length, appointed him to the work, not without a stipulation on the part of the latter that the troops, together with all that savoured of military terrorism, should be dismissed before he entered upon what should be solely a work of peace and mercy. One other stipulation Fénelon made,-that he should be allowed to choose his fellow-workers. Both of these points were granted, and Fénelon at once selected the Abbé de Langeron, his lifelong friend; the Abbé

'Euvres, vol. iii. pp. 35, 235. 
Fleury (the well-known historian), the Abbé Bertier, and the Abbé Milon, who later on became respectively Bishops of Blois and of Condom. Thus accompanied, Fénelon set out for his new sphere of work, going first to the Bishop of Rochelle (Henri de Montmorenci de Laval) to seek his blessing.

The people of those provinces, which had so long been the scene of religious strife and war, were at first amazed to see men of high birth and position leave the Court and capital to come among them. They supposed that, at all events, such men would be luxurious and haughty, according to the descriptions they were wont to hear from their ministers of the Great Babylon and its denizens; and when, on the contrary, they saw in the missioners nothing but lowly, self-denying, simple-mannered priests, whose real aim seemed the welfare, temporal as well as spiritual, of those they lived among, prejudices began to melt away, and the Huguenots saw that all they had been told was not truth. The line of action adopted by Fénelon is best set forth in his own letters. He writes to the Marquis de Seignelai : ${ }^{\mathrm{x}}$ -

$$
\text { “A la Tremblane, Feb. 7, } 1686 .
$$

“. . . . If these good beginnings are kept up by kindly preachers, who know how to join the power of

I Secretary of State, and brother of the Duchesses de Beauvilliers, Chevreuse, and Mortemart. 
winning the people's confidence to that of teaching them, they will be made true Catholics. . . . (Feb. 26.) -In the present condition of men's minds, we could easily bring them all to confession and Communion if we chose to use a little pressure, and so glorify our mission. But what is the good of bringing men to confession who do not yet recognise the Church, nor her power of remitting sins? and how can we give Jesus Christ to those who do not believe that they are receiving Him? Yet I know that in places where the missionaries and the troops work side by side, new converts crowd to receive Communion. A very little pressing causes them to make any number of sacrileges,-the work is looked upon as done when they communicate; but in truth such men are only goaded to despair by remorse, or plunged into an indifferentism and coldness, which is the height of impiety, thereby propagating a race of scoundrels who will spread over the country. We should expect to bring a terrible curse upon our work if we were satisfied with a hasty, superficial work, all meant for show. We can but multiply our instructions, invite the people to come heartily to the Sacraments, and give them to those who come of their own accord to seek them in unreserved submission. . . I I must not forget to add that we want a great quantity of books, especially New Testaments, and translations of the Mass, with explanations." 
"March 8, 1686.

". . . The corn you have sent so cheaply proves to the people that our charity is practical; it is the most persuasive kind of controversy. Ours amazes them, for they see the exact reverse of all that their ministers had taught them as incontestable truth. . . . I do not doubt but that there will be a great number of communions at Easter; too many perhaps. . . . We need preachers to explain the Gospel every Sunday with a loving, winning authority;-people brought up in dissent are only to be won by the Word spoken to them. . . We must give New Testaments profusely everywhere, but they must be in large type; the people cannot read small print. We cannot expect them to buy Catholic books; it is a great thing if they will read what costs them nothing: indeed, the greater proportion cannot afford to buy. If we take away their books and give them nothing else, it would seem to confirm the ministers' favourite fiction, that we will not let them read the Bible, for fear they should discover the condemnation of our superstitions and idolatries!"s

At the same date Fénelon wrote to Bossuet: "Our converts get on but very slowly;-it is no trifling matter to change the opinions of a whole pecple. . .

${ }^{1}$ Correspondence, vol. i. pp. 5-14. 
The Huguenots, when only nominally converted, are most obstinately attached to their religion, but the moment that any suffering is in prospect their courage fails. Whereas the martyrs were humble, docile, intrepid, and incapable of falsity, these men are cowardly, and ready to commit any hypocrisy. The remnant will fall into an indifference to all religious externals which makes one tremble. If one wanted to make them abjure Christianity and accept the Koran one would only have to show them a troop of dragoons. So long as they meet together by night, and refuse to listen to instruction, they are satisfied. It is a dangerous leaven in a nation. They have violated holy things so constantly by perjury, that there is great difficulty in distinguishing the really sincere converts. We can but pray to God for them, and persevere, without being disheartened, in teaching them." ${ }_{x}$

In this same letter to Bossuet, Fénelon playfully threatens to be guilty of "some grievous heresy, in order to incur a lucky disgrace which should recall me to Germigny." Shortly after he was permitted to return to Paris, where, after certain personal interviews sought by the King, who desired to hear what had been going on for himself, Fénelon withdrew altogether from Court for more than two years, occupying himself

$\therefore$ Correspondence, vol. ii. p. 297. 
entirely with his quiet and unconspicuous duties among the Nouvelles Catholiques.

So little did he trouble hinself about the affairs of the outer world, that it was merely by accident that he heard of his own appointment to the See of Poitiers, and of its immediate revocation. This was a piece of spite on the part of de Harlay, who was increasingly jealous of the Abbé de Fénelon, and who, finding that he could not succeed in making him be forgotten, as he had promised, was at least determined to keep him out of the higher dignities of the Church, if possible. The next year the Archibishop was again successful in his unworthy manœuvres. The Bishop of Rochelle had been greatly impressed by the zeal and gentle wisdom of the young missioner, and he now came to Paris, without giving Fénelon any hint of his intention, to ask the King to appoint him as Coadjutor-Bishop of Rochelle. De Harlay did not hesitate to insinuate to the King that the attraction between the two men was a mutual leaning to Jansenism, and as this was always a bête noire to Louis XIV., he at once refused to make the appointment. Fénelon might easily have refuted these assertions, which his close friendship with Bossuet, Tronson, etc., pretty well answered; but he did not take the trouble to do so. He was not ambitious of dignities, and he was occupied at this moment in publishing his two 
books-on Education and on the Ministry. These works were eagerly read and appreciated, and de Harlay's opposition fell unnoticed by its subject. $\mathrm{He}$ was content to look forward to a life spent in teaching God's Truth in a humble sphere, by writing, preaching, and ministering. But God in His own time called His servant forth to a more extensive scene of labour, although probably he never again knew so peaceful and unanxious a season as that which closed with his appointment as Preceptor to the Duc de Bourgogne in August 1689. 


\section{CHAPTER II.}

7 HE time had come when the little grandson of 1 Louis XIV., the hope of France (for his father the Dauphin was an uninteresting, heavy person, unlikely ever to be a fitting successor to the Grand Monarque, and wont to say himself that he was content to be the son and father of kings, without becoming one himself), required to pass from the hands of nurses under a masculine rule. The King seems to have taken all arrangements into his own hands, almost without consulting the Dauphin, who, if asked, would probably have said, "Give my son just the contrary of all that was given to me." Poor man, he had had a brilliant and intellectual household enough, but he was too dull and unimpressionable to care for or benefit much by that; and the tenderness and elasticity which might possibly have developed something more in him were wanting. The Duc de Montausier and Bossuet had been selected to bring up the Dauphin, as 
the greatest and most celebrated men of their day, but the Duke was a dry, stiff man, whose Cato-like virtues and ducal robes enfolded a dry, pedantic nature, as Sainte-Beuve says; ${ }^{x}$ and Bossuet, though he tried to be kind and patient with the stupid little boy, had not Fénelon's intimate acquaintance with child-nature, and endeavoured to make him good and intellectual by writing profound treatises and magnificent discourses, which failed in their effect upon their original object, however much they may have benefited the world at large. Probably the King himself had somewhat altered his views about education, and Madame de Maintenon, whose influence was by this time telling materially upon him, threw its weight into an altogether different channel. It was most likely that influence which led to the appointment of the Duc de Beauvilliers as Governor to the royal grandson.

Paul Duc de Beauvilliers had been at Court nearly all his life, having early succeeded Marshal Villeroy as head of the Conseil des Finances, and being also First Gentleman of the Chamber.2 He had been Governor of Havre, and, in I688, Louis XIV. sent him with the Dauphin to the siege of Philisburg, practically in charge of that not very able prince. He was acknowledged on all sides as a man of remarkable piety and

"Nouveaux Lundis, "Louis XIV. et le Duc de Bourgogne."

" Mémoires de Saint Simon, vol. i. p. I68. 
purity of life, and as a courtier sans reproche ${ }^{\mathrm{x}}$-no common thing in those days. Saint Simon enlarges upon his personal attractions and courtesy, as well as his goodness, and Madame de Sevigné remarks that Saint Louis himself could not have made a wiser choice. ${ }^{2}$ The Duke had married Colbert's second daughter, her two sisters marrying the Ducs de Chevreuse and Mortemart, men of his own stamp, and the three families lived in a close union of principle and action, which gave them great strength amid a profligate, time-serving Court. Madame de Maintenon had always been closely allied with them; they had steadily refused to bow before Madame de Montespan in her day of ascendancy, although M. de Mortemart was her nephew; but they acknowledged and respected the difference of Madame de Maintenon's position, and rejoiced in being able to resume their proper place at Court and about the Monarch when a more decent state of things was initiated. 3 Twice a week regularly Madame de Maintenon used to dine at the Hôtel de Beauvilliers, where the society was at once select, intellectual, and devout, and she can hardly be accused of consulting mere personal friend-

× Correspondence, vol. xi. p. 200, "Discours sur l'Éducation du Duc," etc.

${ }^{2}$ Lettres, vol. ix. p. 426.

3 Mémoires de Baumelle, vol. ii. p. 248. 
ship in urging such an appointment upon the King. It was most unreservedly made; for Louis XIV. left the selection of all who were to be about the important child to the absolute discretion of the Duke, with the one exception of an old servant named Moreau, who had been his attendant from the time of his birth.

The Duke had no hesitation as to the best Preceptor France could produce for the little Prince, and immediately named Fénelon. Madame de Maintenon took upon herself some of the credit of this appoirtment, ${ }^{x}$ for Fénelon's goodness and talent, as well as the charm of his manners, had impressed her so favourably during her frequent meetings with him at the Hôtel de Beauvilliers, that she thought of seeking him as her permanent director. The Duke, to his credit be it spoken, never wavered in his friendship for Fénelon through evil report and good report, and to his dying day the latter, whose mind and intellect, D'Aguesseau says, were infinitely superior to the Duke's, ${ }^{2}$ maintained an unbroken influence over him and his. Fénelon was leading his ordinary retired life, neither seeking nor expecting Court favour, and he received the tidings both of his friend's and

1 Memoires, vol. vi. p. 196.

- Euvres du Chanceler D'Agruesseau, edit. Pardessus, vol. xv. p. 348 . 
his own appointment by the same letter, to his great surprise.

Bossuet learnt the news at Germigny as soon as Fénelon himself, and-priding himself on having had some share in bringing so admirable a person to light -he hastened to write his congratulations to Madame de Montmorenci-Laval :-

$$
\text { "Aug. 19, 1689. }
$$

"Yesterday, Madame, I was absorbed in the good fortune which has befallen us in Church and State, to-day I have had leisure to dwell more immediately upon your joy, which gives me the liveliest satisfaction. It brings my admirable and beloved friend, your late father, very forcibly before me, and I have been picturing to myself how he would feel on this occasion, seeing the shining forth of merit which has concealed itself so long. Enfin, Madame, we shall not lose the Abbé Fénelon; you will be able to enjoy him, and, provincial as I am, I shall escape from time to time to go and embrace him. Accept, I intreat you, the expression of my joy, and the assurance of the respect with which I remain, etc.,

$$
\text { J. BÉNIGNe, }
$$

Évêque de Meaux."

Although it has been already partly quoted in the Life I Correspondence, vol. ii. p. 307 . 
of Bossuet, ${ }^{\mathrm{x}}$ it is impossible to write that of Fénelcn without giving the letter written to him on this occasion by his beloved friend and director Tronson, a letter so unlike the ordinary congratulations and lavish admiration which poured in upon the new appointments :-

" August 1689.

"You will perhaps be surprised that I have not already been found amid the crowd of those who are congratulating you on the honour conferred on you by his Majesty; but I very humbly beg you not to judge hardly of my brief delay. I felt that on an occasion which interests me so deeply, I could not do better than begin by thanking God for His dealings with you, and asking Him to continue to bless and guide you. I have tried to do both to the best of my ability; and having said this, I may assure you that I was really delighted to hear that you were appointed.

"The King has given an evidence of his piety, and a satisfactory proof of his discernment, by this appointment, which in itself is very comforting. The education now committed to you by his Majesty so closely concerns the welfare of the State and the good of the Church, that every good Frenchman must rejoice to

I Bossuet and his Contemporaries, p. 357. 
see it in such hands. But I must tell you honestiy that my joy is mixed with fear when I consider the perils to which you are exposed; inasmuch as it cannot be denied that, in the ordinary course of things, all promotion makes a man's salvation more or less a work of increased difficulty. It opens the door to earthly greatness, but you must fear lest it should close that of the real greatness of Heaven. It is quite true that you may do very great good in the position you fill, but you may also be guilty of grievous faults ; for there is nothing indifferent in such an office;your actions, good or bad, must almost inevitably have infinite results. You are thrown into a region where the Gospel of Jesus Christ is little known, and where even those who know it use their knowledge chiefly as a means to win human respect. You are about to live among people whose language is altogether heathenish, and whose example almost universally tends in a perilous direction. You will find yourself surrounded by a multitude of objects which flatter the senses, and are specially calculated to rouse your most dormant passions; and you will need a great grace and a prodigious stedfastness to withstand impressions at once so vivid and forcible. The horrid mists which prevail at Court are enough to obscure the clearest and plainest truths. It does not require a long familiarity with its tone to make a man look 
upon precepts which he once appreciated and believed, while meditating at the foot of the Cross to be unquestionable, as exaggerated and extravagant. Duties which once seemed imperative insensibly begin to appear doubtful or impracticable, and a thousand occasions arise when you will fancy that prudence and charity itself constrains you to deal gently with the world. Yet surely it is a strange position for a Christian, still more for a Priest, to find himself forced to compound with the enemy of his salvation! In truth, dear friend, your post is a dangerous one;-confess honestly that it is very difficult not to lose ground in it, and that you need a very confirmed grace to stand therein. If ever the study and meditation of Holy Scripture were necessary to you, now indeed they have become overwhelmingly indispensable. Hitherto, perhaps, you have needed them chiefly to fill your mind with good thoughts, and nourish it with truth; but henceforth you will need them as a shield from evil and falsehood. Now is the time for you to remember S. Augustine's words, 'Continuis vigiliis excubare, ne opinio verisimilis fallat; ne decipiat sermo versutus; ne se tenebræ alicujus vis erroris offundant; ne quod bonum est, malum; aut quod malum est, bonum esse credatur; ne ab iis quæ agenda sunt metus revocet, aut ne in ea quæ agenda non sunt cupido præcipitet.' Above all, it is of the most infinite 
importance that you never lose sight of the eventful hour of death, when all this world's glory will fade away like a dream, and every earthly stay on which you may have leant must fail.

"Probably your friends will comfort you by reminding you that you did not seek the post, and certainly that is a real satisfaction, and a great mercy of God; but you must not rest overmuch upon it. One often has more to do with one's own promotion than we imagine; it is very rare that any man foresees and yet sincerely avoids it,-one does not come across many who have attained such a height of self-abnegation. A man may not eagerly seek commonplace means of advancing himself, but nevertheless he does not fail to put aside obstacles cleverly: he may not court those who can advance him, but he is not sorry to let them casually see his best side; and it is just to these little bits of human display that the first steps of his promotion are to be attributed, so that no one can say quite confidently that he has had no part in his own elevation. The display of one's own talents, which one often makes almost without thinking about it, is really a very great peril, and it is well always to strive to neutralize it by the aspirations of a humble and contrite heart.

"I am afraid you will think this letter too long and too unreserved, in fact more like an ill-timed sermon 
than an acceptable congratulation. I should assuredly have been briefer and less free-spoken if I cared less for your soul ; and if there is any lack of respect in my letter you must attribute it to my heart's love, which cannot be other than warmly alive to your true interests. Moreover, all the polished congratulations you will have received will make up abundantly for my rough speech. Believe, I intreat you, that I shall never cease to pray that God would fill you with the unchanging spirit of His Love, so that no temptation may alter or weaken the strength with which it will inspire you. It is the Church's prayer for her children.-I am," etc. ${ }^{\text {. }}$

As the Duc de Beauvilliers received the King's absolute confidence, so he gave his own to Fénelon, who in his turn was left to select those who were to work under him-a selection carried out in the persons of three admirable men, the Abbé de Langeron and the Abbé Fleury, who had already been his fellowlabourers in Poitou, and whose intellectual qualifications, no less than their moral and religious character, fitted them thoroughly for their work; and, lastly, the Abbé de Beaumont, a nephew of Fénelon's, who shared not only his uncle's labours through ten long years without ever asking or receiving the smallest

${ }^{I}$ Correspondence, vol. ii. p. 307 . 
Court favour, but who also shared his disgrace. It was not until another reign, when his large-hearted uncle was in his grave, and the voice of envy and slander silenced, that, in 1716 , De Beaumont was appointed Bishop of Saintes. He was second Sousprécepteur, the Abbé Fleury being first, as was natural, seeing that he had already conducted the education of the Prince de Conti and the Comte de Vermandois. Langeron filled the post of reader to the little Duke.

Fénelon was at this time thirty-eight, and the unanimous testimony of all who have mentioned him in contemporaneous writings sets him before us as a singularly gifted and attractive man. The Duc de Saint Simon, himself too entirely a man of the world really to understand any one who was not actuated by a worldly spirit, and whose satirical, misanthropical character colours all his impressions, gives a most fascinating description of Fénelon, although he so far misinterprets the great Archbishop's life as to say, that "no man ever possessed so inveterate a desire to please every one, from the prince to the peasant; and no man ever pursued that desire with a more steady, continuous, universal persistence; neither did any one ever succeed more entirely." ${ }$ To the last sentence we may cordially assent, but those who will patiently follow the course of Fénelon's life will be ready to

'Mémoires, vol. xxii. p. 137. 
say that, if he possessed so strong a desire to please, it was certainly held in very wondrous control by a stronger conscience, which led him to say and do things most unacceptable to the highest quarters when duty interfered.

Saint Simon gives a graphic description of Fénelon's appearance:- " This prelate was a tall, thin man, well made, pale, with a large nose, eyes whence fire and talent streamed as from a torrent, and a physiognomy the like of which I have never seen in any other man, and which, once seen, one could never forget. It combined everything, and the greatest contradictions produced no want of harmony. It united seriousness and gaiety, gravity and courtesy, the man of learning, the Bishop and the grand seigneur; the prevailing characteristics, as in everything about him, being refinement, intellect, gracefulness, modesty, and, above all, noblesse. It was difficult to take one's eyes off him. All his portraits are speaking, and yet none of them have caught the exquisite harmony which struck one in the original, or the exceeding delicacy of every feature. His manners altogether corresponded to his appearance, his perfect ease was infectious to others, and his conversation was stamped with the grace and good taste which are only acquired by habitual intercourse with the best society and the great world. $\mathrm{He}$ possessed a 
natural eloquence, graceful and finished, and a most insinuating yet noble and appropriate courtesy; an easy, clear, agreeable utterance; a wonderful power of explaining the hardest matters in a lucid, distinct manner. Add to all this, that he was a man who never sought to seem cleverer than those with whom he conversed, who brought himself insensibly to their level, putting them at their ease, and enthralling them so, that one could neither leave him, nor mistrust him, nor help seeking him again. It was this rare gift which he possessed to the utmost degree which bound all his friends so closely to him all his life, in spite of his disgrace at Court, and which led them, when scattered, to gather together to talk of him, regret him, long after him, cling more and more to him, like the Jews to Jerusalem, and sigh and hope for his return, even as that unhappy race waits and sighs after their Messiah." I

A not less attractive portrait is given us by a very different stamp of man, the Chancellor D'Aguesseau, who, in his Mémoires sur les Affaires de l'Église de France, says: "The Abbé de Fénelon was one of those rare men who are destined to create an epoch in their times, and to do honour as much to humanity by their virtues as to letters by their exceeding talent; easy, brilliant, characterised by a fertile, graceful,

x Mémoires, vol. xxii. p. 135 . 
dominant imagination, which yet never made its domination felt. His eloquence was rather winning than vehement, and he reigned as much through the charm he had in society as by the superiority of his talents; always bringing himself to the level of others, and never arguing, seeming on the contrary to yield to others at the very time he was convincing them. ${ }^{x}$ His lips poured forth graciousness, and he seemed to handle the weightiest matters with perfect ease, while the veriest trifles assumed dignity beneath his hand, and he could have brought forth flowers from amid thorns. His whole bearing was marked with a noble singularity, and a je ne sais quoi of sublime simplicity gave a sort of prophet-like stamp to his character : the fresh though unaffected way in which he expressed

${ }^{x}$ One of the men who was continually with him, and therefore saw Fénelon in all circumstances,'the Abbé Galet, says, "I never knew him speak brusquely to any one, nor to the best of my knowledge did a harsh or contemptuous word ever escape him."-Recueil, etc. See Corres. vol. xi. p. 149.

And de Ramsai writes: "He had the faculty of putting himself on a level with all minds, never seeming to feel cleverer than those with whom he was talking, but rather bringing out their powers by an unconscious graceful setting aside his own. I have seen him adapt himself within a short space of time to all classes-associating with the great, and using their style without any loss of episcopal dignity, and then turning to the lowly and young, like a kind father teaching his children. There was no effort or affectation in his readiness to turn from one to the other, it seemed as though his mind naturally embraced all varieties." Hist. de la Vie, etc., p. 168. 
himself made many people fancy that he knew everything by inspiration. It seemed almost as if he had invented rather than acquired the sciences. He was always original, always creative, imitating no one, and himself wholly inimitable. His talents, which had been long hidden in collegiate obscurity, and were little known at Court even when he went on the Poitou mission, were at last brought fully forth on the King's appointing him to educate his grandson."

Certainly it was a marvellous staff of educators which was brought to bear upon the prospective King of France; and the material to be worked on was of no ordinary kind. Anything more unlike his heavy, unintellectual father than this little Duc de Bourgogne could hardly be imagined. He was indeed an enfant terrible, and that of the most perilous kind.

"Monseigneur was born with a naturel which made one tremble," Saint Simon wrote, while the Duke was still living." "He was so passionate that he would break the clocks when they struck the hour which summoned him to some unwelcome duty, and fly into the wildest rage with the rain which hindered some pleasure. Resistance made him perfectly furious. I have often been a witness to this in his early childhood. Moreover, a strong inclination attracted him to whatever was forbidden to body or mind. His satirical power was all I Euvres, vol. viii. p. 195. $\quad{ }^{2}$ Mémoires, vol. xv. p. 79. 
the more biting that it was clever and pungent, and he seized promptly on the ridiculous side of things. All this was sharpened by an elasticity, mental and bodily, which became impetuosity, and which made it impossible for him in early days to learn anything without doing two things at once. He gave himself up to all that pleased him with violent passion, and with an amount of pride and hauteur past description; he was dangerously quick in penetrating both things and people; in seeing the weak side, and in reasoning more powerfully and deeply than his masters. But, on the other hand, as soon as the storm of passion was over, reason would return and get the upper hand; he would see his faults and acknowledge them, sometimes so regretfully as almost to renew the storm. His mind was lively, quick, penetrating, resolute to meet difficulties; literally speaking, transcendent in every way. The marvel is that in so short a time devotion and grace should have made an altogether new being of him, and changed so many redoubtable faults into the entirely opposite virtues."

We must not anticipate now what the little Duke became as a man $;^{\mathrm{x}}$ at seven he certainly promised

"Sainte-Beuve says: "Ce qui est certain, c'est que lorsque Fénelon reçut entre les mains, pour l'élever, ce jeune prince agé de sept ans, il en fut effrayé à première vue. Il reconnut aussitôt à quel point la matière sur laquelle il allait avoir à travailler était 
badly. Besides the above description of Saint Simon's, he tells us in various places that the Duc de Bourgogne was intensely obstinate, desperately fond of good eating, of hunting, of music and of games, at which it was dangerous to play with him, as he could not endure to be beaten; that he was disposed to be cruel, and that he looked upon the rest of mankind as an inferior race with which he had nothing in common. Even his brothers, who were supposed to be brought up on precisely the same footing as himself, he considered as merely a sort of link between him and the ordinary human race! Now, indeed, Fénelon's studies on Education would be tested, and the theories he had written must be put into practice. Yet, perhaps, the wisest point in the whole business was that, as Cardinal de Bausset says, "he pursued only one system, which was, to have none !" in other words, he devoted his elastic, fertile mind to meeting the necessities of the hour as they arose in his volatile, chameleon-like pupil, instead of subjecting him to a bouillante et rebelle, d'autant plus dangereuse qu'elle était pleine d'esprit et comme pétrie de salpêtre et de feu. Un Néron, un Domitien pouvait en sortir aussi bien qu'un Titus, si l'on manquait l'œurre et si l'on se trompait de moule. Par les férocités, le manque d'équilibre et le déchaînement des passions brutales jointes aux vivacités et aux caprices de l'imagination, il y avait l'étoffe d'un monstre. C'était une rude affaire que de tirer de là un roi et un homme."-Nouveaux Lundis, vol. ii. p. Ii6.

${ }^{x}$ Histoire de Fénelon, vol. i. p. 105. 
Procrustean system, which would probably have made him finally wicked or idiotic! How generally wise and tender his notions of the fitting treatment of a child were may be gathered from his treatise. "Let the child play," he says, "and mingle instruction with play; let wisdom only show itself to him occasionally, and then with a cheerful face; beware of wearying him with an indiscreet precision. If he gets a gloomy, disagreeable impression of goodness, while freedom and disorder are associated in his mind with what is pleasant, all is lost. . . . What matters most is for you to see your own faults as plainly as your pupil will see them. Very often people excuse nothing in a child, while they excuse themselves in everything. . . . Try to make the duties you require him to fulfil acceptable to him. If you are obliged to put an irksome duty before him, give him to understand that it will be followed by some pleasure; show him the use of what you teach him.... Otherwise study will seem an abstract, barren, painful toil to him. Children ask within themselves what is the good of learning things which are not mentioned in conversation, and which have nothing to do with their ordinary life? Explain to them that all these bear upon the duties to which they will hereafter be called, form their judgment, and train them to enter upon the business of life. . . . Never, without the most urgent necessity, be stern and 
dictatorial .... or you will close the children's hearts against you, and destroy conscience, without which there is no hope of educating them rightly. Make them love you, accustom them to be open with you, and not to be afraid of letting you see their faults; and to this end be indulgent to such as they do not try to conceal. Never seem surprised or vexed at their naughty ways, but, on the contrary, be pitiful to their weakness. . . . You must often bear with things which need correction, waiting till the time when the child is able to benefit by it. Never reprove while either you or he are excited. If you do so on the spur of the moment, he will see that you are acting from temper or haste, not from affection and justly; and you will lose your authority irrecoverably. And if you reprove him in his own first excitement, he is not able to acknowledge his fault, to conquer his passion, or even to feel the importance of what you say; and he runs the risk of losing his respect for you.' Show him that you always know how to control yourself; nothing will teach him that so much as your patience. Watch, if need be even for several days, for the best moment at which to correct a fault; and never tell a child of a fault without suggesting some encouraging way of conquering it; and always avoid the vexation and fret caused by a hard manner of correction. . . . People who never praise children must 
dishearten them. While praise is to be feared because of vanity, you should try to use it as a means of encouragement without hurting them. S. Paul often used it to encourage the weak, and make his rebukes easier to bear. Of course, to be useful, praise must be free from all exaggeration or flattery, and all good must be referred to God as its Source."

The enfant terrible did not become a lamb at once! We have a picture of him drawn from the life by his Preceptor, and given to him as a wholesome lesson in his happier moments, which bears out Saint Simon's description. Fénelon writes the following paper as a sort of jeu-d'esprit, half to amuse his pupil, half to rebuke him. It is called "Le Fantasque."

"What can have happened to Melanthe? Nothing from without; everything within. $\mathrm{He}$ has all to his mind, everybody seeks to please him. What then is the matter? He is bilious. When he went to bed last night he was the joy of the whole earth; this morning one is ashamed of him, - he must be hidden. When he got up some shoe-string offended him; so the whole day will be stormy, and everybody will suffer! He frightens one,-it is deplorable; he cries like a child, he roars like a lion. An evil sullen cloud blackens his mind, as the ink out of his desk blackens × Euvres, vol. xi. pp. 135-157. 
his fingers. Don't talk to him about the things he liked best a minute ago,- - just because he liked them then, he cannot abide them now. The amusements he longed for bore him, and must be given up. He contradicts, pities himself, annoys others; he is angry if they will not be put out. Sometimes he fights with empty space, like a mad bull tearing at the winds with its horns. And if he can find no excuse for attacking others, he turns against himself, blames himself, thinks himself good for nothing, loses heart, and is indignant if anybody tries to comfort him. He wants to be alone, and cannot bear solitude; he returns to society, and is cross with it. People do not talk, and such an affectation of silence irritates him: they speak low, and he fancies they are talking of him : they speak loud, and he thinks them noisy and unfeeling because he is sad. They are grave, and he thinks they are reproaching him; they smile, and he thinks they are laughing at him. What can be done? Nothing but to be as firm and patient as he is unbearable, and wait quietly in hopes that to-morrow he will be as good as he was yesterday. These strange tempers go as they come; when they seize him, it is like a machine with a broken spring; he is like one's idea of a person possessed, his reason seems upsidedown, he is the embodiment of unreason. If you urge him on, he will maintain at mid-day that it is 
night,- - there is neither day nor night for one so upset with caprice. Sometimes he cannot help being amused at the vehemence of his own absurdity, and in spite of his vexation he smiles at the extravagant things he has uttered! But how is one to foresee these storms and avert the tempest? There is no way; no almanac foretells this bad weather. Beware of saying, "To-morrow we will go and amuse ourselves in such a garden.' Your man of to-day will be quite another to-morrow; he who promises so much now will soon disappear: you will not know how to call his words to his mind: you will find nothing but a shapeless, nameless something, which you could not define two minutes running in the same terms. Study him as much as you please, and then say what you will of him; it will not be true the next moment. This je ne sais quoi wills and will not; he threatens and trembles; he mixes up the most ridiculous pride with the most unworthy meanness. $\mathrm{He}$ cries and laughs, he jokes and is furious. In his most comical and senseless fury he can be witty, eloquent, crafty, full of ingenious devices, although he has not a grain of sense left in him! Take good care to say nothing fair, exact, and reasonable to him; he will know how to take advantage of it and turn upon you; he would forget his mistake for yours, and become reasonable solely for the pleasure of proving that you are un- 
reasonable. A nothing has sent him up into the skies; but what has become of that nothing? It has been lost in the fray, it is forgotten: he does not know what put him out, he only knows that he is angry, and is determined to be angry, or indeed sometimes he does not even know that! Sometimes he imagines that every one who speaks to him is in a rage, and that he only is temperate; like a man with the jaundice, who fancies everybody is yellow, though the colour is only in his own eyes. At any rate, perhaps, he will spare certain people to whom he owes more than the rest, or whom he seems to love better? Not at all; his whims spare no one; they seize on whatever comes across them, and expend themselves on the first comer; if once he is put out, he will abuse everybody. He does not care for anybody, nobody cares for him, he is persecuted, betrayed, he owes nothing to anybody whatsoever! But wait a moment, and the whole scene is changed! He wants every one, he loves and is loved, he flatters, win', enchants the very people who could not endure him; he confesses how much he was to blame, laughs at his absurdities, caricatures himself, and that so well that you would almost think one of his attacks of rage had returned. After such a comedy, played at his own cost, you would imagine that at any rate he would not become a demoniac again. But, alas! you are mistaken, he will do it again to- 
night, and ridicule himself to-morrow, without amending!"x

A tolerably strong lesson this, one would think, for the proud little Prince, who hardly thought himself made of the same pâte as his fellow mortals! Another of the same kind is also preserved to us. Fénelon wrote a supposed letter from Bayle to himself, purporting to describe a recently discovered medal,- - a thing certain to excite the curiosity and interest of the Duc de Bourgogne, whose literary tastes were precocious. The description of the medal is read aloud :-

"One side represents a child of noble and beautiful mien; Pallas holds her shield over him, and the Graces strew his path with flowers; Apollo, followed by the Muses, offers him his lyre; Venus hovers above in her chariot, and lets her girdle drop upon him; Victory points with one hand to a triumphal car, and with the other offers him a crown. The legend is taken from Horace, 'Non sine Dis animosus infans." "

So far all is very delightful, and probably the little Duke began to consider the medal very happily suited to himself! But then there comes a reverse side :-

"The reverse is altogether different. Evidently it represents the same child-there is the same figure, × Euvres, vol. xi. p. 295. 
but he is surrounded now with hideous and grotesque masks, venomous reptiles, snakes, vipers, insects, owls, filthy harpies, clawing with their hooked nails. There is a troop of impudent mocking satyrs, assuming the most absurd postures, laughing and pointing to the monstrous fish's tail with which the beautiful boy's body is completed. And around the legend, again from Horace, says, 'Turpitur atrum desinit in piscem.' Our savants are greatly perplexed to discover on what occasion this ancient medal can have been struck. Some maintain that it represents Caligula, who, as the son of Germanicus, kindled so many hopes in childhood, but developed into a monster. Others again think that it is intended for Nero, whose beginning was so bright and his end so horrible. All agree that it represents a brilliant young prince, whose promise was fair, and yet deceitful." x . . . .

The hidden meaning was assuredly not lost upon the royal pupil!

A number of fables, some in French, some in Latin, and (as we should call them) fairytales, written in like manner, to convey some special lesson to the little Duke, remain among Fénelon's works,- some poetical and graceful, though the taste for that style of mythological composition

$$
{ }^{2} \text { Euvres, vol. xi. p. } 299 .
$$


has passed away from among us, and their usefulness would probably be very much less now than at the time they were written. Thus one day we find the little Duke's carelessness in his lessons delicately shown up to himself beneath the fable of young Bacchus being taught by Silenus beneath a sacred oak, while a saucy little Faun, listening to the royal reader, grins and jeers at his false quantities and mistakes. At last Bacchus, irritated at the criticism, exclaims angrily, "How dare you ridicule the son of Jupiter!" and the dauntless Faun replies, "How dare the son of Jupiter make a slip!" But these fables were not always armed with a sting; sometimes they carried a pleasant and complimentary meaning when the child for whom they were written deserved a reward; e.g. in Le Rossignol et la Fauvette, which is considered by French critics as "the most exquisite " 2 of Fénelon's writings. Fables seem to have been very much to the taste of the young Duke, who had a special predilection for La Fontaine and his writings. The old poet condescended to write fables in competition with the Prince, and (here we fear he must stand convicted of flattery!) to declare himself conquered! His reward-for to a courtier it probably would have been one-was a graceful lament over La

CEuvres, vol. xi. p. 394.

2 Sainte-Beuve, N. Lundis, vol. ii. p. 126. 
Fontaine's death, written by Fénelon and translated by the little Duke.

The child's literary education was not the burdensome side of Fénelon's preceptorship, though he spared no pains in that, as the remains of his own papers, gathered together by his nephew de Beaumont, Bishop of Saintes, prove, besides his published works. At that time, with the exception of a few elementary works put forth by the Port Royalists, there were scarcely any educational books, grammars, or handbooks; and the teacher who wished really to do his part thoroughly found himself obliged to prepare written lessons which should supply what now every schoolboy finds ready printed in his hand. Thus Fénelon drew out rules, and wrote outlines of themes and passages for translation; even putting together a sort of Latin dictionary, which set forth the precise weight of words and their parallels in French. But all this trouble was rewarded by the pupil's interest in his studies, and his classical taste, which was unnaturally early in its development. The Abbé Fleury says that his was a first class mind-his perceptions quick, his memory clear, his judgment correct, his reasoning powers accurate, and his imagination lively. He was not content with superficial knowledge, but liked to get to the bottom of things, and he was possessed by a boundless spirit of curiosity! At ten years old he 
was able to write elegant Latin, and to translate with a nicety of expression unusual in older people. $\mathrm{He}$ could enter into the beauties of Horace, Virgil, Ovid and Cicero (so we are told); and a year later he had translated Cæsar's Commentaries and begun to translate Tacitus. He drew freely and with genius; he was passionately fond of music and studied it scientifically, and was wont to go into extasies over all that pleased him in art or poetry. The Abbé Fleury says that the little Duke was difficult to teach at first in spite of all these capacities, because his exceeding liveliness and impetuosity made it hard for him to take in rules and details-he liked to carry everything before him by his quickness of perception, rather than to plod. Yet he had an innate taste for detail, against which Fénelon in after years struggled with the keen sense of a large-minded man, that it would be harmful to him as a ruler. Thus we find Fénelon writing to the Abbé Fleury, that the Duke's natural inclination led him to a childish love of detail in the fine arts and in agriculture; and but a short time before the cherished pupil's death, Fénelon writes to the Duc de Chevreuse (as devoted as himself), that in religious matters the Dauphin still needed to acquire a habit of steady, consecutive application, in order to take in all the various sides of a subject, to give due balance to what was really important, and to 
shake off difficulties, "otherwise," he says, "he will be but as an inquisitive butterfly, hovering over all the weightiest subjects, without ever becoming a good man of business. He .wants nervous force, and firmness, without which evanuerunt in cogitationibus suis." I

But to return to the Duke's childhood. The real struggle was with his fiery temperament, already described, which in its actual outbreaks was not to be dealt with by fables or allegories. Patience and gentleness, together with firmness, were the only means of meeting these attacks of fury, which had probably been altogether mismanaged hitherto in nursery government. When one of the evil moods seized him, it was an understood thing in the household that every one relapsed into an unwonted silence-nobody spoke to him if they could help it; his attendants waited upon him with averted eyes, as though reluctant to witness his degradation through passion. $\mathrm{He}$ was treated with the sort of humiliating compassion which might be shown to a madman;-his books and appliances for study were put aside as useless to one in such a state, and he was left to his own reflections. Gradually these would bring the passionate but generous child to a better mind, and then, full of remorse and penitence, he would come and throw × Correspondence, vol. i. p. 542. 
himself, in the fullest affection and trust, mixed with childish remorse, upon the never-failing patience and goodness of the Preceptor, whom he almost worshipped to his dying day;-suffering more real pain from that which he was conscious of having caused to one whom he loved far better than he could possibly have loved his father, than from the severest punishment that could have been inflicted. Gradually he learnt to assist those who strove to conquer his faults by his own efforts. A slip of paper is still existing, brought by the little Duke to Fénelon when he was eight years old, written in his own hand :-

"I promise, foi de prince, to M. l'Abbé de Fénelon, that I will do at once whatever he bids me, and will obey him instantly in what he forbids; and if I break my word, I will submit to every possible punishment and dishonour. Given at Versailles, Nov. 29, I689.

And again :-

(Signed) Louis."

"Louis, who promises anew to keep my promise better. Sept. 2oth. - I beg M. de Fénelon to let me try again."

It was seldom that the impetuous but affectionate child did not yield speedily to Fénelon's wise and loving discipline. Once, however, there was a serious scene between them, which appenss to have had a lasting 
influence upon the Prince. It is his biographer, M. Proyart, who tells it. Fénelon had been obliged to reprove the Duke with more than usual severity, and the boy, in his angry pride, had resisted, exclaiming, "Non, non, Monsieur, je sais qui je suis et qui vous êtes!" Such insubordination was fatal to his authority, of course, if tolerated : but, acting upon his own maxim, never to administer reproof while either actor concerned is excited, Fénelon made no reply, and for the remainder of the day preserved a total silence towards his pupil, who could not fail to perceive by his manner that the usually indulgent master was both hurt and displeased. Night came, without any explanation; but the next morning, as soon as the Prince was awake, the Abbé came to his room, and addressing him in a grave, ceremonious manner, very unlike the usual easy tone of their intercourse, said, "I do not know, Monsieur, whether you remember what you said to me yesterday, that you 'knew what you are and what I am,' but it is my duty to teach you your ignorance alike of both. You fancy yourself a greater personage than I,-some of your servants may have told you so; but, since you oblige me to do it, I must tell you, without hesitation, that I am greater than you. You must see at once that there can be no question of birth in the matter. You would consider him a madman who should take to himself any 
credit because the rains of heaven had watered his crops, while those of his neighbour withered; and it would be no wiser to be vain of your birth, which adds not one tittle to your personal merit. You can have no doubt but that I am your superior in understanding and knowledge-you know nothing but what I have taught you, and that is a mere shadow compared with what you yet have to learn. As to authority, you have none over me, whereas I, on the contrary, have a full and entire authority over you, as the King and Monseigneur have often told you. Perhaps you imagine that I think myself fortunate in holding the office I fill about yourself; but there again you are mistaken. I undertook it only to obey the King and please Monseigneur, and in no way for the irksome privilege of being your Preceptor; and to convince you of this truth, I am now going to take you to his Majesty, and beg him to appoint some one else, whose care of you will, I hope, be more successful than mine."

Nuit porte conseil, even to passionate children, and the little Duke had wakened to a very different estimate of himself, his Preceptor, and life in general, from that which attended his coucher the evening before. He really loved Fénelon, and, small as he was, he was sensitive to the last degree as to public opinion and the faintest shadow of disgrace. What 
would the world think of the Prince who was so hopelessly naughty that a man so universally admired and respected was forced to give him up? and what would become of the poor little boy to whom his nearest relations were after all only "His Majesty" and "Monseigneur," if the dear, kind Preceptor who loved him, and devoted himself to him, were to go away and leave him?

Poor little Louis! the storm broke out anew, but this time it was all penitence and shame and regret; while, with passionate sobs and tears, he cried out, " Oh, Monsieur, I am so sorry for what I said yesterday!... If ycu tell the King, he will not care for me any more, ... and what will people think if you leave me! I promise, oh, I promise ever so much, that you shall not have to complain of me, if only you will promise not to go !"

But Fénelon would promise nothing-the lesson would be lost if it were not sharp, and for a whole day he allowed the little Duke to undergo the pangs of anxiety and uncertainty. At last, when Louis' repentance seemed unlikely to be soon forgotten, Madame de Maintenon's intercession was admitted, and the Preceptor consented to remain. The separation, when it did come, between the attached master and pupil, was voluntary on neither side, and nothing ever succeeded in separating their affections. 
Bossuet had endeavoured to educate this boy's father with the very highest pressure, and had not succeeded in bringing forth much either of intellect or feeling. Fénelon made a friend and companion of the son, and while developing his heart, his intellect (which undoubtedly was greatly superior to that of the then Dauphin) developed rapidly likewise. The following letter, written by Fénelon to the Père Martineau, gives an attractive picture of the way in which master and pupil lived together, and the groundwork of their attachment :-

"In his childhood," the Archbishop writes, Nov. 14, 1712, "he was sincere and ingenuous, to the degree that one only needed to question him in order to know whatever he had done wrong. One day, when he was very much out of temper, he tried to conceal some act of disobedience, and I urged him to tell the truth, remembering that we were in God's Sight. Then he threw himself into a great passion, and said, 'Why do you put it in that way? Well, then, since you ask me so, I cannot deny that I did,'--whatever it was. He was beside himself with anger, but still his sense of religious duty was so strong that it drew forth the most humiliating acknowledgments. I never corrected him save where it was really necessary, and then with great caution. The moment his passion was over, he would come back to me and confess himself to blame 
so that we had to console him, and he was really grateful to those who corrected him. He used sometimes to say to me, 'Now I shall leave the Duc de Bourgogne behind the door, and be only little Louis with you!' This was when he was nine years old.

"I used to leave off lessons whenever he wanted to begin a conversation from which he might derive useful information; and this happened rather often : we got back to our study all in good time, for he had a liking for it, and I wanted to give him the taste for sensible conversation, both to make him sociable and to accustom him to make acquaintance with those whom he would meet in society. In such talks as these his mind made rapid strides in literary, political, and even metaphysical knowledge, and he went through all the evidences of religion. His temper was improved by this sort of intercourse; he used to become quiet, pleasant, and lively, so as to be quite delightful. All his pride melted away, and he enjoyed such times much more than childish games, which often put him out of temper. I never knew him care for flattery : if he was praised he would take no notice at first; and then, if any further remark was made, he would say that he knew his own faults too well to like praise. He has often told me that he should never forget the pleasure it was to learn as he did, without any constraint. I have known him ask to be read to during 
his meals and while dressing, so eager was he to learn; and I never saw any child who so early and so keenly entered into the refinements of poetry and eloquence, or who could so soon understand abstract principles. Directly that he saw me doing any work for him, he wanted to do the same, and would set to on his own account. Except in his moments of passion, I never knew him influenced save by the most straightforward principles, and most strictly in accordance with the teaching of the Gospel. He was kind and courteous to all who had a claim upon him, but he reserved his confidence wholly for such as he believed to be religious people, and they could tell him nothing about his faults which he did not acknowledge with gratitude. I never saw any one whom I should less have feared to displease, by telling him the harshest truths concerning himself. I have proved that by some wonderful experiences." $x$. . .

The little Duke's education was carefully planned by Fénelon, even when unable himself to carry out the details. The following is a specimen of instructions written by him, and found among the Abbé Fleury's papers :-

"For the rest of this year I would let the Duke go on as at present, with his themes and translations,the first from Ovid's Metamorphoses. The subjects are ${ }^{x}$ Correspondence, vol. iv. p. 169 . 
very varied; he learns a great many Latin words and idioms; they amuse him, and as themes are the hardest part of his work, it is well to make them as amusing as possible. His translations are alternately from one of Terence's Comedies and the Odes of Horace, which he likes very much; nothing can be better either as a matter of Latin or taste."

Fénelon goes on to suggest various ecclesiastical and general history, classical authors, and other reading, remarking that the instructor should watch his pupil's progress, and vary the study if his interest flags; petty detail he would have avoided, and matters of argument should be postponed until with a riper judgment he can derive more pleasure and profit from them than were now possible.

He next refers to an abstract of Cordemai's History, on which the little Duke had been engaged, suggesting that it should be varied by one from Roman history, made with careful chronological notes and tables; as also by Duchesne and English history.

A year later another similar scheme includes Holy Scripture, select portions of the Fathers, especially S. Augustine, Bossuet's Histoire des Variations, various histories, grammar, rhetoric, etc.; but these latter studies are to be carefully employed, and not made burdensome.

It seems needless to say that, while all points of 
secular education were so carefully attended to, the little Duke's religious instruction was not neglected. In his treatise on Education, Fénelon explains his ideas as to this, the most important point of all, i.e. the need of laying a thorough and painstaking foundation of sacred history, linking it on to the Christian dispensation- "Jesus Christ awaited in the Old, reigning in the New Testament." This mode of teaching, he says, requires more time and pains than many are willing to give; but then, on the other hand, those who have thus laid a solid foundation have a firm grasp of their religion, whereas, very often, people who have not been well taught have only confused ideas about our Lord, the Gospel, the Church, her authority, and the real nature of their obligations as Christians. Fénelon would follow the teaching of Holy Scripture, and bring vivid pictures of God's dealings with men, His Power, Judgment, etc., to bear upon the childish imagination; and, while avoiding mere philosophic subtleties, he would lead it to think upon mysteries and wonders which, though past human comprehension, raise the tone and kindle aspirations. Above all, he dwells upon the importance of the example set before a child by his instructors, which will teach far more than any precepts; and here, at least, the Duc de Bourgogne was fortunate, for no higher or purer example of the beauty of a personally devout life 
could be given him than that of his beloved Preceptor.

The early religious impressions which Fénelon gave him were so firm and deeply rooted that they influenced his whole life; and though, as might be expected, there were then, and have been since, men who considered a devout prince as a kind of monster, there is every reason to believe that the Duc de Bourgogne's life was more useful to his country, and his death happier for himself, than that of most princes of his family. Later on we shall find Fénelon anxiously guarding his pupil against falling into any narrow grooves, or allowing his religious practices to interfere with his duties, either public or with respect to his grandfather the King or the Dauphin his father. And the broad, large-hearted wisdom of his counsels in later life are sufficient testimony to what his teaching of the child was,- - probably, indeed, nothing but a deeply religious training could have overpowered the strong tendencies to evil which struggled in the Duke against so much that was noble and good. In his book on Education, Fénelon says, that the period of First Communion must be long looked for, and the child taught to feel that he should be really trying to be good before he is admitted to what he has learnt to look to as the greatest blessing of this life; while, at the same time, he would have the First Communion 
given as early as may be, to strengthen and shield the child before he meets with real danger and temptation. In this spirit his pupil was prepared, and the result was all he could have desired. The Duc de Bourgogne made his First Communion earnestly and devoutly, and during the rest of his life he was a regular and faithful communicant. Saint Simon himself, who wrote at some length to prove that he was "too religious," mentions that the Duke never communicated less frequently than once a fortnight, and that with a recollection and humility of bearing which struck all beholders. $\mathrm{He}$ always on these occasions wore his order and collar of the Saint Esprit as a token of respect. But we shall have hereafter to return to this subject.

It was during these years of preceptorship that Fénelon wrote his Dialogues des Morts, for the Prince's instruction, and with a view to teaching him how to weigh character and form historical judgment. The Dialogues are short, and for the most part lively, sometimes indeed abounding in humour and playfulness, and often giving more true than flattering characters of well-known personages. The dialogues between Louis XI. and Cardinals Balue and Bessarion, and Philippe de Comines, are specially graphic. In the latter the King reproaches the great 
historian for having told many things which he would fain have had concealed, for, as he says, "Tout cela est fort ridicule." "Mais," de Comines replies, "tout cela n'est-il pas vrai? Pouvois-je le taire?" "Vous pouviez n'en rien dire," says the aggrieved monarch. "Vous pouviez n'en rien faire!" is the answer. And in spite of Louis XI.'s rejoinder, "Mais cela étoit fait, et il ne falloit pas le dire!" the historian has the last word, bidding the King remember that he might have told much worse things and have been believed; and that kings who wish to be well spoken of have only one resource,-to act well! Charles V. and a young monk of Saint Just, whose slumbers the restless ex-Emperor persists in disturbing ; Cardinals Ximenes, Mazarin, and Richelieu, are all spirited and interesting sketches; and another topic, quite free from politics, is touched upon in the dialogues between Parrhasius and Poussin and Leonardo da Vinci.

'Fénelon wrote a History of Charlemagne, which was never published; of his Télémaque we shall have to speak later on.

Although the Duke de Bourgogne was the prominent pupil, and the one whose memory is most closely connected with that of Fénelon, he had charge also of the Duc d'Anjou (afterwards Philip V. of Spain), and, for a very short time only, of the Duc 
de Berri; and the former at least always retained a warm affection for his Preceptor.

Those were days in which disinterestedness was rare, and men were not the less esteemed because they strove to profit themselves and their families to the utmost in whatever position they filled. Consequently, it is the more remarkable that not only did Fénelon make to himself a rule, which he steadilykept, never to ask anything on his own behalf or that of his family or friends; but that he actually continued in a state of extremely straitened means for more than five years after entering upon his honourable position about the royal children. Letters to Mme. de Laval, who was his guide and counsellor in money and domestic matters, show this. He writes (October 1689), telling her that he has been obliged to spend 500 francs in stores, which only leaves him twenty pistoles for current expenses; and he does not know whether he will receive any money when the Court returns from Fontainebleau. In an account of his moneys given in the same letter, we find "the sale of my carriage and ponies;" and he adds, "As to the maitre d'hôtel's accounts, I follow your advice precisely, and hope to learn to be economical." " In March $169 \mathrm{I}$ he again mentions having repaid rooo out of a debt of 1200 francs to Mme. de Laval, - Correspondence, vol. ii. p. 15 . 
and other sums to other people, "all without having received one sou except my actual salary, and nothing at all from Carenac, which is hopelessly ruined. Consequently, I have made retrenchments, which are very unusual in my position; but justice comes before all other considerations. I still owe a considerable sum to my bookseller, and I must buy some plate, and repay you for the things you have lent me, which are worn out." ${ }^{x}$ And in July $169 \mathrm{I}$ he writes, "I return the plate, my dear cousin, which you have so long and so kindly lent me. I cannot restore other things which I have been using these three years, but as you have a list of them, I beg you will put a price upon them, and add it to what I already owe you. Do not suppose I ask it from any lack of confidence in you; - there is no one to whom I would so soon be indebted as you. I owe you too much to have any false delicacy in the matter, but it is necessary to go into the accounts in order that I may see my way in my small economies, and calculate how to go on." 2 Again, January 1694, he writes concerning a needy person whom he commends to Mme. de Laval: "Although my necessities have never been so pressing as at present, I beg you to take what is wanted. .. . I am tolerably well, though very busy; but my purse is at the lowest ebb, through the delays in pay-

- Correspondence, vol. ii. p. 24.

2 Ibid. p. 27. 
ment of my salary, and the exceeding dearness of everything this year. If $I$ do not receive something shortly, I must dismiss nearly all my servants. But I will not have you try to help me; I should return anything you sent me! I would rather bear on. All the same, see that any money that can be sent [from Carenac] reaches me, after the more urgent alms have been dispensed, for indeed I would rather live on dry bread than let any of the poor of my benefice want. In God's Name, my dearest sister, I beseech you to enter into my mind about this, and to help me as I wish to be helped."

This cousin became Fénelon's sister actually, as well as in name, by her second marriage with his eldest brother the Comte de Fénelon, and probably it never cost him more to refuse anything than when he refused her request, that he would obtain a valuable military post for her son, a child of four years old. But, while ready to do anything he thought right to please Mme. de Laval, he steadily refused to make the application she desired. "I cannot relax the strict rule to which I feel it right in my position to adhere," he writes. "I would do anything on earth for you or your son that I can, but not to save my life would I ask for anything from the King."

It was not till I694 that the King seems to have - Correspondence, vol. ii. p. 53 .

2 Ibid. p. 26. 
remembered or discovered how badly his grandson's Preceptor was provided for. In that year, at last, he gave Fénelon the Abbey of Saint Valéry. Meanwhile the world's honours and admiration fell thick upon the Abbé, who was a universal favourite among all who knew him. He was chosen as a Member of the Académie Française in 1693 , and, made his reception speech March 3 Ist in that year; and while avoiding the general society of Paris and the Court, he lived in close association with what was certainly then the crême de la crême thereof, among the de Beauvilliers, de Chevreuse, etc. Mme. de Maintenon grew more and more attached to him: there are frequent allusions to him in her letters, - his esprit, and his yet greater saintliness, "which is just what suits me." And she had very nearly placed herself under his permanent spiritual direction. "I have often wondered since how it came to pass that, when hesitating, I did not choose the Abbé Fénelon, whose every manner pleased me, and whose goodness and talent had so won me."

Mme. de Maintenon did consult him frequently about her institution at Saint Cyr, which occupied so large a share of her thoughts, and he was associated with Bourdaloue, the Abbé Godet des Marais, subsequently Bishop of Chartres, and other eminent

I Lettres de Mme. de Maintenon, vol. ii. No. $3^{6 .}$

- Mémoires de Mme. de Maintenon, vol. vi. p. 198. 
ecclesiastics, in its government. Moreover, the great lady, struck probably by the remarkable simplicity and truthfulness of the Abbé, asked him to tell her what he believed to be her chief faults, - $a$ demand which led her friend the Maréchal de Villeroi to say, after reading the reply, years later, "One must confess that there is just a touch of vanity in such a discussion of a person's own faults!"

The answer is very long, but there is so much in it valuable in itself, as well as characteristic both of Mme. de Maintenon and Fénelon, that some extracts must be given :-

"I can but speak hesitatingly, almost at haphazard, to you of your faults, Madame. You have never been thrown into any continuous action with me, and I think little of what others may have told me of you. Never mind, I will tell you what I think, and God will enable you to use it according as $\mathrm{He}$ sees fit.

"You are natural and ingenuous, and hence, without any effort, you act admirably towards those whom you like and esteem; but you are too cold directly that your taste is not gratified; and when you are dry and hard, you are very hard. I should say that your natural disposition is at once very keen and very slow;-what touches you does so to the quick.

"You have a great deal of inborn pride-I mean that which is called proper, rightful pride, but which 
is really all the more wrong because men are not ashamed to call it right; it would be easier to cure one's self of mere foolish vanity. You have still unconsciously a great deal of this pride; your sensitiveness as to things which touch it closely shows how far it is from being conquered. You cling to the esteem of worthy men, to their approbation, to the pleasant consciousness of accepting your prosperity with moderation; in short, of showing that your heart is superior to your position.

"That ' $I$ ' of which we have so often talked is still an unshattered idol. You wish to give yourself heartily to God, but not through the sacrifice of self; on the contrary, you seek self in God. A sensible pleasure in prayer and in the Presence of God sustains you; but if that pleasure were to fail, the attachment which binds you to self, and the outward tokens of your own virtues, would prove a perilous trial. I trust that God will feed you with the sweetest milk, till 'such time as He sees fit to wean you and give you true bread. But be sure that the smallest attachment even to good things out of self-love will hinder you more than all the failings you dread. God's Light will explain this to you better than I can.

"You are naturally kind and trustful, perhaps rather too much so, towards people you like, without having tested them enough to satisfy prudence. But, on the 
other hand, when you begin to mistrust any one, I fancy your heart shuts up too entirely; it is often thus with frank, trustful people when forced into mistrust. But there is a medium between an excessive, headlong confidence and mistrust which knows no bounds when that on which one rested fails. Your good sense will teach you that, while worthy people often have failings to which one must not blindly give way, they are also to be distinguished by simplicity and straightforwardness, which show pretty well what they really are. There is nothing doubtful or equivocal about the character of a good man to any one who can follow him under all circumstances. The most consummate hypocrisy never attains any likeness to this simple goodness; but one must remember that the most ingenuous goodness is liable to little selfseekings and self-interest, of which it is almost unconscious; so that what we need is neither to be suspicious of people whom we know only to a certain point, nor to give ourselves up unreservedly to them. I say all this to you, Madame, because, in your position, you discover so much that is unworthy, and hear of so much more through the voice of slander, that it is hard to know what to believe. The more one is disposed to like and trust goodness the more perplexed one is under such circumstances; and nothing but a real love for truth, and a certain power 
of discerning what is true, can prevent one from falling into the evil of universal mistrust, which would be a serious evil. ....

"It is generaily believed that you are a sincere lover of goodness: many people have long thought that this arose from a sort of pride, but I fancy the public knows better now, and does justice to the purity of your motives. Nevertheless, it is said, and I should say apparently with truth, that you are hard and severe; that you cannot tolerate any failings in others; and that being hard with yourself, you are the same to others; and that when you begin to perceive any weakness in people whom you have represented to yourself as perfect, you are at once disgusted, and carry your displeasure too far. If what is said concerning you in this respect is true, you will only be able to conquer the fault by long and careful selfdiscipline. But the more you put away self by an absolute yielding to the Holy Spirit of God, the more your heart will expand in compassion to others, and in toleration of their defects. You will see infirmity everywhere, your perceptions will become keener, and will discover more than you see now; but nothing will surprise you, or scandalise you, or shut you up. You will see evil abounding among men as water in the ocean. The world is very indulgent to sin, and yet pitilessly severe upon sinners. Do not you be like 
the world: be faithful and true, but compassionate and tender to sinners, as Jesus Christ Himself was while confounding the Pharisees and their fair outward show. . . . .

"Your zeal for the King's salvation should not make you overstep the limits which Providence seems to assign you. There are many things one must regret, but one must await the opportunities which God only knows, and which are wholly in His Hand. You need not fear being false, so long as you are conscious of such a fear. False people are not afraid of being false; it is only true people who fear lest they should fail in truthfulness. Your piety is honest, you have never fallen into the world's vices, and have long since renounced its errors.

"The true way to win grace for King and country is not to make a great stir or to weary the King with importunity; but to edify him by continual self-renunciation; to win his heart gradually by simple, hearty, patient conduct, by being as honest and simple as a child. But to speak with warmth or bitterness, to be continually attacking him openly or underhand, to scheme and reform with worldly wisdom, is doing evil that good may come. Your own sense will reject such means, and you must listen to it.

"As to business, I really think that you are more capable of it than you imagine; perhaps you mistrust 
yourself a trifle overmuch, or you are unwilling to enter into discussions so opposed to the quiet, recollected life which suits you best. Moreover, I apprehend that you shrink from the kind of people you must encounter in business matters. I persist in thinking that you should never intrude yourself on State affairs, but you should inform yourself concerning them according to your natural capacity; and when God's Providence gives you an opening for doing any good, without putting any undue pressure on the King, you should never draw back.

"So much for what the world says. For myself, Madame, I would add that I think you have still too much natural inclination for friendship, kindness, and whatever links you to the best society. All this is doubtless excellent from the earthly side, but it is all the more needful to know how to abstain. Cold and hard hearts are very faulty; this is a great deficiency in goodness, and if their piety were more advanced, it would supply the want. But all real goodness of heart consists in faithfulness and pure love of God, without which all natural kindness and generosity is but a more refined form of selfishness, all the more seductive, and consequently more dangerous. . . . If you can renounce self, you will no more be keen to see your friends devoted to you than to the Emperor of China! You will love them with the pure love of 
God-a perfect, infinite, generous, active, compassionate, equal, tender love, like that of God Himself. His Heart will overflow in yours; you will seek nothing in others but that which God Himself seeks, and that only for His Sake. You will be jealous for His Sake against yourself, and you will only require affection from others as it promotes their own perfection and God's designs for them. What hurts you in hearts which seem closed to you does so only because your own heart is too much shut up within itself. Nothing so wounds self-love as self-love. The Love of God bears with the infirmity of self-love, and waits patiently till such time as God shall uproot it. . . . You must so entirely sacrifice to God that ' $I$ ' of which we have said so much, as to seek it no more either as regards reputation or the comfort of an internal testimony to your own good intentions and qualities. . . . You should be prepared to find yourself despised, disliked, run down by others, and self-condemned, it may be, in order to give yourself up wholly to God's Will and pleasure. This is a hard thing to say to those who live to themselves, and seek to enjoy a conscious self-righteousness; but it is not so hard to one who loves God as heartily as he renounces selflove. ...

"As to your duties, I have not a moment's hesitation in saying that you should restrict them within a 
much narrower sphere than many over-zealous people would have you accept. Every one, full of his own plans, tries to lead you on, and counts you as indifferent to God's Glory if you are less eager than himself; every one wants you to think as he thinks, and to see things as he sees them. Hereafter, if God opens the way, you may be able to do more extensive good; but at present you have the Community of Saint Cyr, which requires a great deal of attention, and you yourself need seasons of rest and recollection for body as well as mind. Then you ought to follow the course of general affairs, with a view to moderate what may be excessive, and help where you can. You should never tire of making use of whatever God puts into your heart, or of any openings $\mathrm{He}$ gives you in the King's heart to open his eyes and enlighten him, but without any over-eagerness, as I have often said."

Here follows much advice as to the influence Mme. de Maintenon should use in order to keep good advisers about the King; how she should avoid listening to gossip, and try herself to ascertain the real character of those around her; how she should do what lay in her power to discourage mere empty pomp and vain extravagance, seek to draw the Dauphin as near to his father as possible; with sundry other points, such as her dealings with her 
own family, and those who sought her from interested motives. Fénelon concludes by saying, "Finally, be assured that the chief thing to do for the correction of your faults and the better fulfilment of your duties is to work from within, not from without. . . . All our faults spring from our being too much bent on, and bound to, self. Renounce that wretched ' $m o i$ ' in the veriest trifles in which the Spirit of Grace tells you that you are still holding to it." ...

These were scarcely the counsels of a courtier, or of one seeking to ingratiate himself with the powers that be. That there was an inducement to do so Fénelon must have fully realised at this time, for in spite of the honourable appointment conferred upon him, Louis XIV. had never entirely forgotten the prejudice raised in his mind against the Abbé by de Harlay; and indeed there were not wanting detractors to keep up such prejudice. Whether through de Harlay or others, it was suggested to the King that the little Duke's education was imperfectly carried out, that his secular acquirements were sacrificed to a mystic and exaggerated devotion, and that he required a larger and more liberal treatment. The first point was answered by Bossuet, who, having educated the father, was a fit and suitable man to examine the son; and after a long interview with the Prince, the Bishop of Meaux expressed himself as amazed at the extent 
and soundness of his acquirements. The Duc de Beauvilliers came to the front on the other head. "Sire," he said, "I know of but one Gospel, and I hold that I owe it to my God and my King to do the utmost possible to train up a virtuous monarch for France. You can examine the Duc de Bourgogne himself as to his religious practices, and I am willing to make any rightful alterations; but I defy any one to bring forward an instance of any prince whatever who at his age is as forward in all secular education."

It might have seemed to a bystander that Fénelon's worldly prosperity was assured now, and that, humanly speaking, he had nothing left to wish for. But the clouds were gathering round which were soon to break in a storm over his head, never to clear away as far as Court favour and this world's good things were concerned. The cry of Quietism was about to arise and estrange some of Fénelon's closest friends from him. 


\section{CHAPTER III.}

$A \begin{aligned} & \text { SPANISH priest, Michael Molinos, was the chief } \\ & \text { promoter of this system of mysticism which }\end{aligned}$ was destined to create so wild a storm in France. He taught-

I. That "perfect contemplation" is a condition in which the soul neither reasons nor reflects, whether upon God or itself, but passively receives the Divine Light, without making any effort of love, adoration, or other wonted acts of devotion. This condition of passivity Molinos calls Quietude.

II. In this state of perfect contemplation the soul desires absolutely nothing, not even its own salvation; it fears nothing, not even hell; the one only feeling of which it is conscious is utter abandonment to God's Good Will and pleasure.

III. The soul which has attained this state of "perfect contemplation" is dispensed from any need of Sacraments or good works, all which become indifferent to it. The darkest, most criminal imagina- 
tions may touch the sensitive part of the soul without polluting it, because they do not reach its superior side, wherein the will and intelligence abide.

The writings and teaching of Molinos were formally condemned by Innocent XI. in 1687. The system called Quietism was already creeping into France, although in a less marked and offensive form than that in which it was taught by its Spanish promulgators. The history of its progress, and of the chief actors therein, has been already entered upon in the "Life of Bossuet:" nevertheless, at the risk of repetition, some of the threads must be taken up anew in writing that of Fénelon, whose future career was so largely influenced by it. The first appearance of this disturbing element was in the person of a woman, who, though doubtless fanatical, and carried away at times by the love of influence and applause, was certainly sincere in her religious purposes, and undeserving of all the calumny and injustice heaped upon her. Mme. Guyon must have been a very gifted and fascinating person; and had she lived in somewhat later times, she would probably have been worshipped in her own circle in Paris so long as she was the fashion, and then quietly forgotten, instead of being persecuted and imprisoned, and thereby made an historical personage.

Jeanne Marie Bouvières de la Mothe was born at x p. 372. 
Montargis, April 13, 1648. She married at sixteen, and at twenty-eight was left a widow with three children. Her inclinations had always led her to a somewhat demonstrative devotion, and she had while very young fallen under the influence of a certain Barnabite Monk, Père la Combe, of whom (although cruelly calumniated, and worried from prison to a madhouse, where he died) the most carefully-weighed evidence seems to prove that he was only excitable and indiscreet, neither heretical nor immoral, as those who wished to damage Mme. Guyon (chiefly aiming at Fénelon through her) would have had it believed. In $168 \mathrm{I}$ the Bishop of Geneva invited Mme. Guyon to join a Community he was establishing at Gex, and of which this monk, whom she had not seen for ten years, was the Superior. It was an unfortunate reunion, and the Bishop soon began to be uneasy at the excited and illusory tone which crept into the Community. The two who caused this left Gex, and Mme. Guyon followed Père la Combe, whom she is said rather to have directed than obeyed, to Thonon and Vercelli. Wherever this lady went there was a certain excitement raised, and Cardinal le Camus, Bishop of Grénoble, having courteously, but decidedly, dismissed her from that city, she returned to Paris in I687, where, on the strength of her general reputation as a Quietist, and the contents of two little books 
she had published, one entitled Moyen Court et très facile pour l'Oraison, the other L'Explication Mystique du Cantique des Cantiques, Archbishop de Harlay assumed a position of vehement antagonism towards her, and obtained a royal mandate for arresting both her and Père la Combe. This poor man was accordingly seized in October 1687 , and spent the rest of his weary life in the Bastille and the Castle of Lourdes, dying at last, as has been said, in a madhouse, completely worn out. Three months later Mme. Guyon was sent to a convent, and subjected to severe cross-examinations and investigations. Undoubtedly such a measure was not looked upon in those days in the same light in which it would be, were it possible, in our own. We find Mme. Guyon herself advising that a woman whom she believed to be an impostor "should be shut up;" nevertheless, there can be no doubt that she was harshly and cruelly treated, while the notoriously profligate, ungodly life of her persecutor Mgr. de Harlay gives a deeper sense of the injustice exercised towards one whose faults were at all events only the result of mistaken and enthusiastic religious feeling. How much de Harlay's judgment upon this, however mistaken, was worth, it may be questioned. An Archbishop whose

- Correspondence, vol. vii. p. 20 : "Je lui conseillai de la faire enfermer." 
biographer can say without fear of contradiction, " De religion, de croyance proprement dite, il n'en avait pas," I was scarcely the right man to visit severely certain shades of excess in devotion; or one of whom the same biographer writes, "Plus on regarde la vie de cet Archevêque, et plus on y découvre de mấtresses" 2 - an assertion history bears out only too plainly - the right man to insinuate (for the accusations were never clearly set forth) that Mme. Guyon's intimacy with $\mathrm{La}$ Combe had misled her.

The nuns of the Visitation (Rue Saint Antoine), where Mme. Guyon was sent, were almost immediately won by her simplicity and goodness, her patience and resignation, and she seems to have held a little court during her captivity among them. Mme. de Miramion, then at the height of her celebrity for good works, made the prisoner's acquaintance, and was fascinated; Mme. de la Maisonfort, a cousin of Mme. Guyon's, and one of Mme. de Maintenon's chief pets at Saint Cyr, took up her cause warmly; the Duchesse de Béthune, ${ }^{3}$ who had known her from childhood-all became vehement partisans of the oppressed lady; and as all three had constant access to Mme. de Maintenon, and considerable influence with her, they pleaded Mme. Guyon's cause so well, seconded by her own assurances that

' Sainte-Beuve, N. Lundis, vol. v. p. I87.
2 Ibia. p. 183 .
3 A daughter of Fouquet. 
she was ready to renounce any error of which she was convinced, and to burn all her books, that at the end of eight months she was set free, ${ }^{x}$ and immediately became a sort of heroine and centre of a group of admiring friends at the Hôtel de Beauvilliers. Up to this time Fénelon had never seen Mme. Guyon, and he was prejudiced against her, as a woman who had neglected her home duties to thrust herself into the unseemly position of a religious teacher. Accidentally passing through her old home at Montargis, however, he heard a good deal about the lady in question, her piety and charity, which led him to suspend his judgment ; and when he met her, as he did frequently,

I Mme. Guyon wrote to Mme. de Maintenon, Oct. Io, I688 : "Madame,-After thanking God for delivering me from the prison where my enemies detained $m e$, it is but due that I thank you, whom God has used to deliver me, as by a miracle, out of the hands of the great ones of the earth. I have obeyed your advice as I would have obeyed God's own orders, and I hope you will not impute this obedience to weakness, but will look upon it as the best way in which I can show my gratitude. At first it went against me; but so soon as the thing was done, I felt joy and peace fill my soul. Père la Combe, my father in Christ, is no more guilty than I am. I am the cause of his trouble. You need but say one word, Madame, and his chains will fall off, and you will have restored to the faithful an innocent and oppressed man, who can teach and edify them. My God, Thy Will, and not mine, be done! I had set out to throw myself at your feet, but an inward voice constrained me to give it up and return here. I await your commands. May the Lord guide and inspire you. I shall never cease to ask this of Him, or to be," etc. etc.-Lettres de Mme. de Maintenon, vol. ii. p. 193. 
at the Hôtel de Beauvilliers, after he became Preceptor, he too was completely won, and allowed himself to become one of her intimate friends. Saint Simon describes the select little coterie-the de Beauvilliers, de Chevreuse, de Mortemart, Mme. de Béthune, Mme. de Morstein, Mme. de Guiche, and a few moreamong which Mme. de Maintenon became intimate with the prophetesse, as he calls her ${ }^{\mathrm{I}}$ and before long the latter was as engoué as any of them, and took her share in the religious conferences and expositions given by Mme. Guyon with enthusiastic delight. Very shortly, seconded by Mme. de Brinon, then Superior of Saint Cyr, and Mme. de Maisonfort, the foundress of that institution brought her new friend thither; and not unnaturally, bringing as she did the prestige of a persecuted saint who had charmed the pick of the Court, and acquired so much celebrity and admiration, the ladies of the Community went nearly wild about her, and she was almost worshipped at Saint Cyr, where her books, manuscripts, and instructions became the rage. ${ }^{2}$

I Mémoires, vol. ii. p. 109. Saint Simon writes as though Fénelon had introduced Mme. Guyon into this circle, but this is an obvious error.

2 " Toutes les fois que Mme. Guyon alloit à St. Cyr, elle etoit écoutée comme un oracle, reconduite comme une sainte. Les dames qui n'avoient pas de devotion, en acquirent: celles qui en avoient, en eurent davantage."-La Baumelle, Mémoires, vol. iv. p. 23 . 
The immense mass of correspondence connected with this subject is almost unmanageable in its bulk. Scarcely an eminent person of the day but was mixed up with it, and we have volumes upon volumes of letters from them, many most interesting in the abstract, but impossible to quote without extending these pages to as unmerciful a measure as their own. Mme. de Maintenon writes to her numerous correspondents perpetually on the subject. Perhaps some of the most interesting letters are those which passed between her and M. Godet des Marais, Bishop of Chartres, and one of the most worthy of French Churchmen. A greater opposite to de Harlay could scarce be found. It is to Mme. de Maintenon's credit that beneath his "long, dirty, emaciated face, and almost silly appearance," on which Saint Simon dwells, ${ }^{\mathrm{x}}$ she should have been able to perceive and appreciate his profound learning and deep piety. Through the intervention of Gobelin and Tronson he had been brought to Saint Cyr as Confessor extraordinary, and it was there, and before becoming Bishop of Chartres, that his intimacy with Mme. de Maintenon, whose director he became, began. When first Mme. Guyon began to assert her influence in Saint Cyr, the Abbé Godet was surprised, and not altogether pleased, to see a woman going out of her place, as he considered it, to teach; but he was

× Mémoires, vol. ii. p. 135 . 
not hasty to condemn her, especially as a friend of Fénelon's, for whom he had a high regard and hearty reverence. However, he expressed certain doubts, which led to a decided lessening of favour on Mme. de Maintenon's part, and at his suggestion she endeavoured to check Mme. Guyon's intimacy in the institution. Fénelon himself did the like, and even remonstrated against some of his own papers, written for individuals, being generally circulated. In a letter to Mme. de Maisonfort, he says :- "I told her [Mme. de Maintenon] from the first, that my little papers were only suitable to a few; but she could not believe it, and, judging by her own taste, would give them to all whom she wished to attract. Later on, experience taught her that I was right, and she told me so honestly, perceiving that these papers contained truths which were very useful to a few, and very dangerous to others."

Mme. de Maintenon confirms this statement in several letters; e.g. she writes to the same lady: "You know that we showed the papers against his will, in your and my imprudence. He both said and wrote several times that they were not fit for everybody, and might even do harm; they were written for individuals, without any precaution. You have often admitted that they had done harm, because they

I Correspondence, vol. vii. p. Io. 
were misunderstood, or taken partially, or misapplied. I am sure he heartily wishes we had not got them." $x$

In another letter to Mme. de Maisonfort (I69r), she says: "Give yourself up entirely to God, and yield heartily to the Abbé de Fénelon and M. de Chartres. I myself shall ever submit to the opinion of these two saints. Accustom yourself to live by them, but do not pour out the Abbé's maxims before people who cannot enter into them. You are constantly talking about the more perfect state, while you are still brimful of imperfections. As to Mme. Guyon, you have prônćed her too much :-we must be content to keep her to ourselves. It is not fitting on her account, any more than on mine, that she should direct our ladies. She has been under suspicion, and that is quite enough for her never to be left in peace. She seemed to me most admirably discreet; all that $I$ have seen of her is edifying, and I shall always met her with pleasure, but our house must be conducted by the

× Lettres, Mme. de Maintenon, vol. ii. p. 202. And again : “Mon peu d'expérience me révoltoit contre M. l'Abbé de Fénelon quand il ne vouloit pas que ses écrits fussent montrés. Cependant il avoit raison. Tout le monde n'a pas l'esprit solide et droit. On prêche la liberté des enfans de Dieu à des personnes qui ne sont pas encore ses enfans, et qui se servent de cette liberté pour ne s'assujetir à rien. Il faut donc commencer par s'assujetir. Embrassés donc avec soumission Dieu qui vous apelle."-Ibid. p. 199. 
ordinary rules. Your perfection lies in not aspiring to be perfect." ${ }^{\prime}$

Mme. de Maintenon was really attached to Fénelon; and now, when the Bishop of Chartres warned her that he was introducing mischief into Saint $\mathrm{Cyr}$, she was slow to believe it. However, she consulted Bossuet and the Bishop of Châlons (de Noailles), who both expressed their suspicion that he was tampering with Quietism, and was dangerous. She then consulted Bourdaloue, Joly, Tiberge, Brisacier, and Tronson, whose letters in reply remain. They all express a more or less modified disapprobation of Mme. Guyon's writings, as containing a spurious devotion, likely to breed illusions and foster Quietism. ${ }^{2}$ Some parts of Bourdaloue's letter may be read with interest.

"I have read and re-read, with all possible attention, the little book which you, Madame, have done me the honour to send me; and as you desire me to give my opinion concerning it, I do so briefly. I am ready to

I Correspondence, vol. vii. p. 196.

2 Joly, Supérieur-Général de Saint Lazare, says: "C'est une chose étrange, que l'esprit de l'homme: nous avons une très grande quantité de fort bons livres, dans lequel il y a beaucoup à apprendre, et à s'édifier : on les laisse, et l'on a la démangeaison de lire des livres suspects, et de la lecture desquels on ne peut recevoir que du préjudice: ce que j'ai lu dans ceux-ci a beaucoup augmenté mon aversion pour le quiétisme, qui est la porte ouverte à l'oisiveté, à l'illusion, et à l'erreur."-Lettres de Messire Paul Godet des MTarais, etc., Abbé Berithicr, 1755, p. 247. 
believe that the person who composed it was well intentioned; but, as far as I am able to judge, I should say that her zeal was not according to wisdom, as is desirable in so important a matter. It seems to me that there is no solid stuff, no foundation upon the true principles of religion in the book; on the contrary, I find various false and dangerous propositions, liable to great abuse, and which are calculated to divert souls from the kind of prayer which Jesus Christ has taught us, and which is expressly commended to us in Holy Scripture; to divert them even to the point of inducing contempt for it. The form of prayer which our Lord prescribed is, that we make individual petitions to God, to obtain, whether as sinners or saints, the special graces which we need for our salvation. That prayer which is commended to us throughout Holy Scripture is meditation on God's Law, kindling our fervour in His Divine Service, impressing our hearts with a reverent fear of His judgments, remembering His mercies, adoring, invoking, blessing Him; calling to mind our past lives as in His Sight, in the bitterness of our soul, examining our duties and obligations in His Presence, and the like. It was thus that David, the man after God's own Heart, prayed, and the Saints of all ages have done the same. But the system of prayer put forth in the book in question is to give up all that, not merely as useless, 
but as imperfect, as opposed to the unity and simplicity of God, and as in some way hurtful to the soul, with respect to the condition in which it is supposed to place itself, when pleased to reduce all things to a simple act of faith, by which it beholds God in itself, beneath the most abstract of ideas, and, without any further effort, waits for God to do all the rest. This method, I repeat, is full of illusion, and is founded upon the misunderstanding of a principle which Quietists abuse-namely, that the soul's perfection in prayer is to renounce all its own supernatural operations, however holy, meritorious, and inspired by the Holy Spirit of God. What perfection can be found in renouncing the most excellent acts of Christian virtue, in which, according to our Lord and His Holy Word, the whole merit and grace of prayer consists?

"But the doctrine of the Moyen Court all turns upon this pretended renunciation, and what I must call this chimerical perfection. I know very well that, during actual contemplation, God can communicate Himself so powerfully to a soul as to arrest all individual action, however good and holy, in it; because the faculties of that soul become, so to say, bound and fixed, and it rather receives God's impress than acts itself; I know, I repeat, that this does happen, - God forbid that I should deny grace, and the gift of infused contemplation. But that the soul should of 
its own accord forestall such a condition, and affect itself to suspend the most sacred acts of prayer, to abide solely by an act of faith, and that it should deliberately choose to forsake the sure path which our Lord has pointed out to follow a new one-which for its very novelty should be looked upon suspiciously, - this I can never accept as the way to perfection. They argue that the soul only does thus in order to give itself up more entirely to God, and leave Him to act within it; but I maintain that the soul cannot prepare itself for Him to work within it better than by doing faithfully that which our Lord Jesus Christ taught us to do in the Lord's Prayer, and which David did in his intercourse with God. And, moreover, I say, that if ever the soul has a right to hope that God would lift it up in contemplation, it would be at the time when, in all humility and faithfulness, it is earnestly occupied in the holy practice of meditation." 1

Bourdaloue concludes with a strong expression of his opinion that it would be much better for many people, in an age of religious discussion and controversy, if they would talk less and do more-a lesson which we of the nineteenth century might not unprofitably heed.

Some of Mme. Guyon's own letters written during ' Lettres, edit. Berthier, p. 252. 
this period confirm one very much in the impression that her zeal lacked discretion, as Bourdaloue says, rather than that her intentions were wrong. Writing to the Duc de Chevreuse, Jan. 20, I693, she says:- "We are what God sees us to be, and that only. If I am criminal, man's approbation will not make me innocent; and if innocent, man's condemnation will not make me criminal." $>$ But it was a great mistake to make her a heroine and a martyr. If Tronson's advice had been followed, and she had been permitted to retire quietly, and be heard of no more, much evil would have been averted. Yet even he says several times that her conversation had worked most extraordinary results among important members of the Court, and that it was difficult not to believe that God's Holy Spirit was with her. ${ }^{2}$ Mme. de Maintenon read some passages of the Moyen Court to the King, but he pronounced them "reveries." " $\mathrm{He}$ is not sufficiently advanced in piety to enter into such perfection," she writes to Mme. de Saint Geran. Nevertheless, she goes on to say that she has desired that these books may not be read any more at Saint Cyr. "It is too strong meat for our ladies; they want milk suitable to their age. All the same, Mme. Guyon edifies them. I have begged her to discontinue her

I Correspondence, vol. vii. p. 14.

2 Tronson to La Pérouse, ibid. vii. 48. 
visits, but I could not refuse them leave to read the letters of a pious, well-conducted person. M. de Paris seems very bitter against her, but even he acknowledges that her errors are chiefly dangerous because of what they may lead to, and that there is more to fear than blame."

It was about this time-the end of 1693 -that Fénelon suggested to Mme. Guyon that she should apply to Bossuet, putting her writings and whole case into his hands, and abide by his decision. This was done, and she seems to have reposed unlimited confidence in the Bishop of Meaux, giving all her papers, even a manuscript autobiography which she had never shown to Fénelon, into his hands. While he examined these papers carefully, the lady retired to a convent in the Rue Cassette, where, in Jan. 1694, Bossuet had a long interview with her, pointing out what he considered her errors kindly and charitably; and, at the same time, he entered upon them with Fénelon, instancing what could only be looked upon as extravagances and absurdities. Mme. de Maintenon writes about the same time:- "Another letter from Mme. Guyon! She is a very troublesome person, but it is true, too, that she is very unfortunate! She wants now to have the Bishop of Meaux, the Bishop of Châlons, and the Superior of Saint Sulpice united to give a ${ }^{2}$ Leitres de Mme. de Maintenon, vol. ii. p. 142. 
definitive judgment on the matters of faith concerning which she is accused, and she promises me blind obedience. I do not know if the King will inflict this mortification on M. de Paris; for, after all, the heresy has arisen in his diocese, and it is his place chiefly to decide. You may be sure he will give up nothing of his rights! The Abbé de Fénelon is too pious not to believe that one can love God solely for Himself, and too clever to believe that one could love Him amid the grossest vice. He has assured me that he only takes part in this business to guard against any accidental condemnation of really devout minds. $\mathrm{He}$ is not Mme. Guyon's advocate, although he is her friend : he is the defender of piety and of Christian perfection. I trust in his word, because I have seldom known any one so honest as he is, and you may say so."

Fénelon's letters to Tronson fully bear out this assertion $;^{2}$ and to Mme. de Maisonfort he writes:"Do not think about your cousin [Mme. Guyon] except to pray for her, and to sacrifice to God all that nature prompts in such a matter to a kind heart like

'Lettres de Mme. de Maintenon, vol. ii. p. I43.

2 "En tout cela, il ne s'agit point de Mme. Guyon, que je compte pour morte, ou comme si elle n'avoit jamais été. Il n'est question que de moi, et du fond de la doctrine sur la vie intérieure. Souvenez-vous que vous m'avez tenu lieu de père dès ma première jeunesse. Je ne veux être ni accusé ni flatté."-Correspondence, vol. vii. p. 97 . 
yours. God will take care of everything, and your business is only to seek His Will, holding fast to Him, and in so doing you will find whatever is agreeable to His True Spirit. Remember that the path of faith and general detachment which you have so desired to follow is only true and trustworthy in so far as we are detached from persons, books, help, in a word, from all that is not God and His Will. . . Be obedient, then, as a little child; I only ask you to do what I am doing myself. I should count myself a monster rather than a priest if I were not actuated by the desire to be as simple, docile, and lowly as I intreat you to be. Once more, then, be obedient, and show that, as Holy Scripture says, ${ }^{x}$ "the righteous are a loving and obedient people.'" 2

Many of the details of this period have been already given in Bossuet's Life, including what are called the Conferences of Issy-the Commission Mme. Guyon had asked for (though not, as she wished, including lay judges) meeting at that place, where the Saint Sulpiciens had a country house, partly as a matter of convenience to their Superior Tronson, now an old man, whose health was failing, and quite as much to

× This reference to Ecclus. iii. I, "Filii sapientiæ, ecclesia justorum, et natio illorum, obedientia et dilectio," is lost in the English version.

2 Correspondence, vol. vii. p. 132 . 
keep the Archbishop of Paris, who was respected by none of them, and whose prejudices they were alive to, in the dark. Up to this time no personal feeling or irritation on the part of either Bossuet or Fénelon appears. The former assented to Mme. Guyon's wish to retire to the Visitation Convent at Meaux, ${ }^{x}$ and live there as a sort of prisoner on parole, pending the sittings of the Commission, and there seemed a reasonable hope that the storm disturbing the religious world would die away.

The Conferences were held at irregular periods, and constantly interrupted by the necessity both Bossuet and de Noailles were under, of frequently returning to their respective dioceses, Meaux and Châlons.

Fénelon was not at first on the Commission, but he was intimate with the three theologians who formed it, and greatly interested in the matter; consequently, he

I Among the masses of correspondence of this period, we find a letter to Mme. Guyon from the nuns after she had left them, which it seems fair to that lady to quote :-

“ De notre Monastère a Meaux, ce 9 Juillet 1695.

"Vous avez si puissamment gagné les cœurs de cette communauté par vos bontés et les exemples de votre vertu, qu'il nous est impossible de laisser partir Mlle. Mare, sans la charger de ces foibles témoignages, qui ne vous prouveront jamais assez la juste estime dont nous sommes prévenues en votre faveur. La connoissance que nous avons de la générosité et de la tendresse de votre cœur, nous fait espérer que vous nous ferez l'honneur de nous aimer un peu," etc. etc. 
was in frequent communication with them, and was often consulted, especially by Bossuet, while the (socalled) Articles of Issy were being framed. Bossuet had owned himself ignorant of most of the mystic writers, and said he had never read S. Francis de Sales, or the Blessed John of the Cross; and, at his request, Fénelon sent him extracts from many of the Fathers-S. Clement of Alexandria, S. Gregory Nazianzen, and others-to show that the earlier writers used what may be called exaggerated language as much as more modern authors, and that neither ought to be taken in their most literal sense. There are numerous letters of this period on the subject, most interesting in themselves, but too lengthy to quote, showing how gradually the divergence of opinion was raising a barrier between the two men which was unhappily to become at length impassable. Fénelon expressed himself with the greatest openness and straightforwardness as to all he believed and taught, and it is hardly possible to believe that Bossuet really thought him a wild heretic (as he afterwards professed), or, considering how great his influence with the King and with Mme. de Maintenon was, Fénelon's appointment would scarcely have been made at this moment, as it was, to the See of Cambrai.

It was on February 4, I695, that the King announced to the Abbé de Fénelon that he had 
nominated him Archbishop of Cambrai. Saint Simon is obliged to admit that Fénelon had in no way sought or even wished for this promotion; but, like the mere man of the world he was, he decides that this could only have been because he wished for something better still, and aimed at being Archbishop of Paris! Worldly men will aliways attribute the motives by which they themselves are ruled to others, and certainly there is no other foundation for Saint Simon's supposition. When the King informed Fénelon of his intentions, he was taken by surprise, but at once replied that he could scarcely rejoice in an appointment which would remove him from his preceptorship to the Princes; whereupon Louis XIV. graciously answered that the Abbé was much too useful to be spared, and that his intention, on the contrary, was that he should retain that office, and not reside in his diocese. Fénelon represented that the laws of the Church and his own conscience made this impossible, as both required residence in the diocese; but the King bore witness to his value for Fénelon's services by overruling this difficulty, and replying, "No, no, the Canons only require nine months' residence; you will spend three months only with my grandsons, and during the rest of the year you must superintend their education from Cambrai, just as if you were at Versailles." 
This point settled, Fénelon went on to say that, if he was indeed to accept the Archbishopric, he must resign the Abbey of Saint Valéry, an act of disinterestedness which Louis XIV. altogether refused to allow. But Fénelon quietly persisted, pointing out to the King that the revenues of Cambrai were such as to make it an infringement of canonical law to hold any other preferment with it. Such conscientious indifference to his own interest seems to have excited a great deal of astonishment and gossip at Court, and Mme. de Coulanges, relating the story to Mme. de Sevigné, goes on to say that M. de Rheims (Le Tellier) remarked, it was all very well for $M$. de Fénelon, thinking as he did, to act thus ; but that, thinking as he did, it was better for him to keep his revenues. ${ }^{x}$

x “M. l'Abbé de Fénelon a paru surpris du présent que le roi lui a fait. . . M. de Rheims a dit que M. de Fénelon pensant comme il faisoit, prenoit le bon parti; et que lui, pensant comme il fait, il fait bien aussi de garder les siennes."-Lettres de Sevigné, vol. xi. p. 143 .

Whereupon Mme. de Sevigné's often bitterly sarcastic editor, Gault de Saint Germain, remarks:- "Ce qui signifioit que le vertueux et illustre Fénelon étoit le prélat des autels de Dieu, et que l'orgueilleux Charles Maurice le Tellier étoit le prélat du trésor de l'ambition. Les prélats de l'éspèce de Fénelon prient pour ceux qui ne les respectent pas; les prélats de l'éspèce de Le Tellier, et il y en a beaucoup trop, lancent l'anathème contre ceux qui les critiquent."

De Baumelle says :- "L'Archevêque de Rheims qui craignoit les suites d'un exemple si dangereux dit brusquement à Fénelon: 'Le bruit court que vous quittez votre bénéfice, quelle folie!' 'Si c'en est une,' répondit Fénelon, 'elle est 
Immediately upon this nomination Mme. de Maintenon and the Bishop of Chartres determined that Fénelon should be put on the Commission sitting at Issy. There is no doubt that Mme. de Maintenon was really attached to him, and also was afraid of his being set down as a Quietist, and that she hoped by this means to avert the danger. He took his place at the Conferences, and the Thirty Articles of Issy, which were already drawn up, were offered to his acceptance. But on certain points he still stood aloof, and hesitated about signing them, saying that if he did so as they stood at present, it would only be out of deference to his colleagues; but that if they would make certain modifications, which he pointed out, he was ready to sign them with his blood. Later on Fénelon's enemies endeavoured to make an accusation against him out of his having said that he would sign the Articles out of deference, as though he had acted a hypocritical part. But he replied that, had he believed the Articles untrue, he would have died rather than sign them; déjà faite.' 'Vous nous perdez tous,' répliqua l'Archevêque! 'Que voulez-vous que le roi pense de M. de Meaux qui a plusieurs abbayes, de M. de Rheims qui en demande encore, de tant de prélats qui croyent qu'être évêques est un titre pour êire abbés, de tant qui en sollicitent, et de tant d'autres qu'on ne rassasiera jamais?' 'Je ne condamne personne,' répondit Fénelon. ' 'C'est à dire,' repartit M.de Rheims, 'que chacun doit suivre sa conscience : eh bien! ma conscience à moi m'ordonne de garder mes abbayes!'"-Mémoires, vol. iv. p. 53 . 
whereas, on the contrary, he believed them to be perfectly true, but insufficient to remove certain difficulties, and set the whole matter at rest. ${ }^{x}$ What he asked was that " disinterested love " should be more clearly explained, and that "passive prayer" should not be authorised without being strictly defined. His brother Commissioners, after two days' consideration, proposed an addition of four Articles, which satisfied Fénelon, and he then signed them willingly. ${ }^{2}$

Fénelon's communications with Bossuet continued extremely friendly up to this point, although the former was not pleased with an Ordonnance published by the Bishop of Meaux in his diocese, condemning all Mme. Guyon's writings. As the time for his consecration approached, the wish seemed strong on both sides that Bossuet should be one of the consecrators; and some of Mme. de Maintenon's letters to de Noailles, Bishop of Châlons, ${ }^{3}$ let us into a whole series of petty

I Réponse à.la Relation sur le Quiétisme.

2 See Articles d'Issy.

3 "Je suis bien aise de vous rendre compte de ce qui s'est passé sur le sacre de M. l'Archevêque de Cambrai. . . . Jusques là je n'avois rien dit au roi, mais voïant tout le monde d'accord, je lui dîs, que j’avois prié $M$. de C. de se faire sacrer à Saint Cyr, et que nous avions choisi M. de Meaux, M. de Châlons, et $M$. de Chartres. Le roi répondit que ce seroit donc $M$. de Chartres qui présiderait à la cérémonie. Je dîs que non : que vous aviez dit d'abord que c'étoit à l'évêque diocesain à présider : mais qu'on avoit consulté, et trouvé que M. de Chartres pouvait céder sans violer les règles ... Je vis bien que le roi 
jealousies and disputes about precedence, arising out of the question of this consecration. Mme. de Maintenon wanted it to take place at Saint Cyr, and the Bishop of Chartres, into whose diocese that would bring it, objected to yielding the chief place in the consecration to another Bishop. The discussion was ardent, and Louis XIV. took a lively part in it; nor was it easy to satisfy the claims and wishes of the differing prelates. However, the difficulty was at last got over by the Bishop of Chartres retiring altogether, the Bishop of Amiens taking his place as second assisting Bishop, Châlons being first assistant, and Bossuet chief consecrator. ${ }^{x}$ Later on, when the breach between the two friends had become painfully wide, Bossuet denied having had any wish to assist on this occasion; but by that time he had written many bitter things against the man he once loved, and had even called him "the Montanus of this new

n'étoit pas persuadé. . . . J'arrivai ici, je vis M. de Cambrai qui scavoit déjà je crois, par M. de Beauvilliers ce qui s'étoit passé, et qui étoit embarrassé par égard pour M. de Meaux. . . . Je proposai, pour avoir les trois évêques choisis, de faire le sacre à Versailles."-Lettres de Maintenon, vol. iv. p. 13.

× De Baumelle says :- " M. de Meaux et M. de Chartres se disputerent l'honneur de consacrer Fénelon : celui-ci fesoit valoir les droits d'évêque diocesain: celui-là représentoit ceux de l'amitié. Des Marais, à la prière de Fénelon, abandonna cette cérémonie à Bossuet, résolu de n'en être pas le témoin puisqu'il n'en étoit pas le ministre."-Mémoires, vol. iv. p. 54. 
Priscilla," I and the inconsistency of such words and such deeds was too glaring to be satisfactory to the Bishop of Meaux' own mind. ${ }^{2}$

Meanwhile the ceremony took place, as proposed, in the Chapel of Saint Cyr, June 10, 1695, in the presence of Mme. de Maintenon and the Archbishop's royal pupils. The new Archbishop immediately went to his diocese. Writing to a friend (a Religious), he says:- "The honour which the King has conferred upon me is one of the greatest one can receive from men; but all that man can give is but 'vanity and vexation of spirit,' as we read in Ecclesiastes. One can only regard this as a heavy burden, and try to bear it faithfully. I am now in S. Peter's position. 'When thou wert young,' our Lord said to him, 'thou wentest whither thou wouldest; but when thou shalt be old, another shall gird thee, and carry thee whither thou

- De la Réponse à la Relation, etc. See Bossuet, Euvres, vol. xx. p. 205.

${ }^{2}$ Fénelon says in a letter to de Chanterac of January I4, I698, replying to Bossuet's assertions, that Bossuet offered to consecrate him, and that it was Mme. de Maintenon who pressed the point. He goes on to say that Cardinal de Bouillon had already proposed to be his consecrator, and that he had all but arranged for it so to be, but "on m'empêcha de raccepter." "M. de Bouillon will remember all this," he says. He narrates the discussions that took place between the different prelates, Père de la Chaise, and the King, saying that he "yielded to what the King wished, as intinated to me by M. de Beauvilliers." -Correspondence, vol. viii. p. 334. 
wouldest not.' I have had a happy, free youth, filled with acceptable study, and intercourse with delightful friends. Now I am entering upon a condition of perpetual servitude in a strange land. Sometimes I do rather feel the change; but I should be very sorry to cling to health, or freedom, or friends, or any other comfort." $x$

Very shortly after Fénelon's consecration (Aug. 6, 1695) de Harlay died, a melancholy, unrespected end, 2 and, as usual, the world became excited as to who was to be his successor. Saint Simon says that the Beauvilliers' party was greatly disappointed not to see the diocese of Paris occupied by Fénelon. De Baumelle says that "the public voice nominated the

× Correspondence, vol. v. p. 407.

2 "Harlai finit une vie impure par une mort honteuse . . . sans donner signe de repentir, il meurt dans les bras de sa maîtresse [la Duchesse de Lesdiguières]. Le roi aprit cette nouvelle à Marli. . . . L'Archevêque de Rheims outragea hautement la mémoire d'un homme sur lequel il auroit dû se taire; car il étoit son ennemi: le roi l'entendit avec indignation: le Comte de Grammont lui dît, 'Monsieur de Rheims, il est bon de vivre!' Nul orateur sacré ne se chargea de l'oraison funèbre de Harlai. Reste de l'ancienne probité. Le P. Gaillard fit un sermon sur l'incertitude de la vie, et ne dît rien du mort."-DE Baumelle, Mémoires, vol. iv. p. 62.

Saint Simon gives an account of his last days, and adds:"Le Père Gaillard fit son oraison funèbre à Notre Dame; la matière était plus que délicate, et la fin terrible. Le célèbre jesuite prit son parti; il loua tout ce qui devait l'être, puis tourna court sur la morale. Il fit un chef-d'œuvre d'éloqu ence et de piété."-Mémoires, vol. ii. p. II4. 
Archbishop of Cambrai to the See of Paris. Mme. de Maintenon asked Hébert, the Curé of Versailles, what the world said about it. $\mathrm{He}$ answered, "Many think that if $M$. de Fénelon had not been so recently appointed, the choice would have fallen on him; and it is so greatly desired, that people hope the King's first favour may prove only an avant-gout of a greater one." ${ }^{\prime}$ Others, again, thought Bossuet the likeliest man. Mme. de Maintenon had fixed her mind on de Noailles, Bishop of Châlons. He was a man of singularly simple, pure life, and the fifteen years during which he had administered the See of Châlons had been marked by disinterestedness and piety. His mother had been a lady-in-waiting to the Queen (Anne of Austria), and lived a life of devotion in his house. Within a few days of de Harlay's death, Mme. de Maintenon wrote to the Bishop of Châlons, inquiring whether he would not consult competent advisers before refusing the Archbishopric, in the event of its being offered to him; and asking whether the welfare of the Church and King were not sufficient motives to make him resolve not to prefer quiet to toil, or refuse a place to which God's Providence should call him, without any seeking on his own part. ${ }^{2}$

I Mémoires, vol. iv. p. 62.

2 Lettres, vol. iv. p. 19. The letter concludes with the words, "Gardez-moi le secret de ce billet, Monsieur, et sans aucune exception que pour Madame votre mère." 
A week later (Aug. I8, I695), Mme. de Maintenon wrote again:- "I can partly enter into the importance and weight of the yoke it is proposed to lay upon you. But, Monsieur, we must all work; you have the advantages of youth and health, and it does not need me to exhort you to sacrifice them to God's Glory, the Church's good, and the King's soul." The next day de Noailles' appointment was made public.

It is evident that Fénelon had been greatly in Mme. de Maintenon's mind on this occasion, and that it was more because she knew the King would not listen to the suggestion, than any reluctance on her own part, which made her reject his name when pressed upon her by Hébert, the Curé of Versailles. ${ }^{x}$ They continued to correspond ${ }^{2}$ and on his return to Versailles, after a brief sojourn at Cambrai, Fénelon's intercourse with her continued on the old footing. Meanwhile a fresh act in this most disagreeable drama had begun, which once more brought Mme. Guyon into uncalled-for prominence. After leaving Meaux, in

Life of Bossuct, p. 397.

2 Sending on a letter of Fénelon's (Sept. 1695) to the ladies at Saint Cyr, Mme. de Maintenon wrote with it, "It is not enough to preach to our daughters, we must set examples of perfection before them: and here is one from an author who is neither suspicious nor unacceptable to them."-Correspondence, vol. vii. p. 201 . 
July 1695 (which she did with a mystery and haste displeasing to Bossuet, who had really been acting kindly by her), she broke her promise not to remain in Paris, or to mix with those members of the Court with whom her influence was considered harmful. Mme. Guyon wrote civilly to Bossuet, and sent him a religious picture; but she concealed her whereabouts, implying that she was on the point of going to the Eaux de Bourbon, and in other ways made it questionable whether she was prepared to act honestly and openly. Bossuet was very much displeased at this, and from henceforward the matter became something very much of a personal quarrel. We have a note from Mme. de Maintenon to de Noailles, dated "Versailles, Mardi, à 7 h ${ }^{\text {res. }}$ du soir, Dec. 1695 . The King orders me, Monseigneur, to inform you that Mme. G. has been arrested. What do you wish done with this woman, her friends, and her papers? The King will be here all the morning: write to him himself." I A few days later, she tells the Archbishop that, having communicated Mme. Guyon's arrest to Bossuet, he answered that he was "delighted at it,"

I A note to this letter in de la Baumelle's edition of Mme. de Maintenon's Letters says: “M. de Meaux had obtained this lettre de cachet. The exempt Desgrés, after a long search for his prey, heard of a little house in the Faubourg Saint Antoine; . . . he obtained a key, and found Mme. Guyon, with two maids, une espece a' Abbé," etc.-Vol. iv. p. 42. 
and that he thought M. de Cambrai and his friends were beginning to feel how they were entangling themselves. In fact, the thing was now becoming a political struggle, and many of those taking part in it probably cared less for the religious side of the subject than for the prospect of overthrowing the de Beauvilliers party at Court. It is evident that Mme. de Maintenon was disgusted at the vehemence with which Bossuet pushed the affair. She writes to de Noailles:-

$$
\text { " Fan. } 5,1696 .
$$

"M. de Pontchastrain has just read a long, tiresome examination of Mme. Guyon-nothing worth repeating to you. The casket has been opened, and M. de la Reynie says it contains nothing but doctrinal papers, which Mme. Guyon says are the copies of those which she placed in M. Bossuet's hands before going to Meaux. . . . It seems to me that this matter will drag on tediously, and take a very disagreeable turn. ... I wish you would write me a letter which I can show, and which might induce them to refer it to you."

\section{And,-}

$$
\text { "Gan. } 9 .
$$

"The King told me what had passed between you, and what he means to say to-morrow to M. de Meaux. I am delighted that you edified him by the gentle way 
in which you dealt with this business: he was quite scandalised at M. de Meaux' proceedings. ... In truth, you have lost nothing in the comparison."

If Mme. de Maintenon's counsels had been followed, the lady would simply have been sent to some country convent, and very little more would have been heard of her. As it was, she was made a martyr at Vincennes; and, irritated at the treatment she received, her examinations and declarations there bore a much more perverse and defiant tone, and Cardinal de Noailles thought it his duty to obtain a more definite retractation from her than that which had satisfied the Commissioners of Issy, while they all sought to make Fénelon express himself strongly on the subject; some, perhaps, "hoping to add affliction to his bonds," others really wishing him to clear himself from imputations of a partisanship which was not likely to do him any credit.

Fénelon was at Cambrai when he heard of Mme. Guyon's arrest, and he remained consistently quiet. Personally he was not mixed up with her; and if his friends or foes had not tried to press him into what he believed to be an unfair, uncharitable condemnation of her individually, and apart from doctrine, he would probably have remained silent. Among the heap of ${ }^{x}$ Lettres, vol. iv. pp. 54-57. 
letters referring to this period, we will only quote a few. Fénelon wrote to Tronson, sending him his papers upon the Articles of Issy:-

" $F e b .26,1696$.

"I beseech you with all my heart, and by the friendship you have shown me for so many years, to examine the papers I send you, carefully, and as soon as possible. The matter is urgent, for I see how Mme. de Maintenon has been worked up into opposition. . . . If anything seems doubtful to you, I will put it into the strongest and most precise terms. If you think me substantially in error, you have but to correct me, and prove my docility. I shall come in a few days to see you, and it is of great importance that you should have seen all the papers, in order to set me right, if need be. So much for doctrine. As to the individual, I am asked to condemn her as well as her works. If the Church gives a formal utterance on the subject, I shall be the first to sign it with my blood; but short of that, I cannot and ought not to do so. I saw things for myself which edified me greatly; why should I be called on to condemn her on account of things which I have not seen, which are no ways conclusive in themselves, and without hearing what she has to say in self-defence? Am I wrong in wishing not to believe what is evil sooner 
than can be helped, and in refusing to curry favour by acting against my conscience? As to the writings, I affirm plainly that I have abstained from examining them, in order to be unable to say anything one way or the other to those who try out of malice to make me speak. If they are even worse than is affirmed, have they not been sufficiently condemned by so many Ordonnances, which no one has disputed, and which have been meekly accepted by the person herself and her friends? What more is wanted? I am not obliged to censure all bad books, especially such as are wholly unknown in my diocese. Such a censure could only be required of me in order to remove suspicion of my own opinions; but there are more natural ways of dispelling such suspicion than by attacking a poor woman who is trodden down by so many, and whose friend I have been. It is not even seemly that I should go out of my way to denounce her writings; the public would not fail to look upon my doing so as a kind of extorted abjuration. Is it not more natural that every one should know that I was one of the four who drew up and signed the Thirty-four Propositions at Issy? Is it not even more to the point that I should write a work in which I should plainly and vigorously condemn all the evil maxims imputed to this person? So doing, the public will see my real opinions. There is no 
need to fear that I shall make a stir by contradicting the books which M. de. Meaux is writing: on the contrary, I purpose entire conformity to his Thirty-four Propositions, and shall only speak of him as my master. My work will be very shortly ready. The Archbishop of Paris and you shall be its judges, and I will gladly submit it also to the Bishop of Chartres, whom I love and respect heartily. As to M. de Meaux, I should be delighted to approve his book, as he desires; but I cannot do so honestly and with a good conscience if he attacks a person whom I believe innocent, or writings which I ought to leave to the condemnation of others, without uselessly adding my censure.-To return to the Bishop of Chartres. He is a holy prelate, and a kind, substantial friend; but through an excessive zeal for the Church and friendship for me, he wants to carry me beyond due limits. I see Mme. de Maintenon is disposed to do the same; he only can quiet her, and you only can convince $M$. de Chartres of the truth of my reasoning, if you are convinced yourself. It is an attempt to lead me on, step by step, by a sort of secret plot, of which M. de Meaux is the mainspring. M. de Chartres acts out of zeal and genuine friendship. Mme. de Maintenon is distressed, and becomes more irritated with each fresh impression given her. A thousand people about the Court bring all sort of 
envenomed gossip to her ears by roundabout ways, because they think that she is disposed to hear it. She and the Bishop of Chartres are convinced that everything is useless if I do not condemn the woman and her writings, a thing which the Inquisition itself would not ask of me, and which I will never do, save in obedience to the Church, were it to see fit to promulgate a formulary, as against the Jansenists. What does it signify if I do not believe Mme. Guyon to be either bad or mad, if I leave her to herself in total silence, and let her die in prison without interfering directly or indirectly in anything which concerns her? The only reason for trying to urge me further must be a belief that there is some mysterious danger in my repugnance to condemn her. But the whole mystery is, that I do not choose to speak against my conscience, or recklessly to insult a person whom I have respected as a saint, so far as anything $I$ have myself seen of her. After all, can my good faith be questioned? Have I acted with dissimulation and policy? Should I be embarrassed as I am if I had yielded to human respect? Why, then, should that be required of me which would scarcely be asked of a man supposed to be an impostor? I beg you to read this attentively, and read it to M. de Chartres if you think good. ... My book will be ready at Easter, and it will agree in doctrine with the papers I now send you. 
After that I have nothing to do but to leave the issue to Providence."

To this Tronson replied (March I, I696) that he and the Bishop of Chartres both thought Fénelon was not called upon to condemn Mme. Guyon or her books, or to approve of Bossuet's, but merely in conversation to grant that they had been rightly censured.

Meanwhile another important letter, written to Tronson by the Duc de Beauvilliers, lets in a good deal of light on the subject :-

“ $F e b .29,1696$.

"I wish to tell you, sir, with the sincerity you know to be my nature, that it is perfectly clear to me that there is a very strong and a very active cabal at work against the Archbishop of Cambrai. M. de Chartres is too good to belong to it, but he is prejudiced, and is also worked upon underhand. As to Mme. de Maintenon, she follows blindly wherever she is led, and imagines herself to be promoting God's Glory when she is ready to proceed to any extremity against $M$. de Cambrai. In short, I see that he is on the eve of being removed from the Princes, as likely to damage them by false doctrine. If they attempt this, and succeed, my turn will probably come; but save for the scandal, I must honestly tell you that I should be ${ }^{2}$ Correspondence, vol. vii. p. 220. 
easily consoled. Indeed, if after such proceedings as these concerning $M$. de Cambrai, you were to think it God's Will that I should not wait to be dismissed, but resign voluntarily, I should feel no reluctance to do so. This you will readily believe, remembering what has already passed between us. To return to M. de Cambrai: I should not advise him, even were he so disposed, to pronounce a formal condemnation of Mme. Guyon's writings. At this moment, when M. de la Reynie [Lieutenant de Police of Paris] has been examining her about us all for the last six weekswhen she is still a prisoner, and her answers carefully kept secret,-were M. de Cambrai to come forward, a year after MM. de Paris and de Meaux, and censure books unknown in his diocese, surely he would give ground for the insputation of being an accomplice of all that is attributed to this poor woman, and of abjuring out of policy and the fear of dismissal. You know, sir, all that I have told you of my own conduct with respect to Mme. Guyon. I have borne with everything, and to this day I keep total silence, and mean to do so, because I am convinced that such is God's Will. But with respect to M. de Cambrai, I feel bound to say openly what may justify him; and if he were to leave the Princes, I should speak all the louder, because I should have a still better hope of convincing. . . A As to the Princes, as I told M. de 
Chartres, there need be no anxiety on their behalf; not one of them knows that such a woman as Mme. Guyon exists, or such a book as the Moyen Court. If we thought it well to practise such reserve with the Duc de Bourgogne, who is very open to religious impressions and very forward in mind, at a time when there was nothing to fear, is it likely that we should now seek to influence him, seeing that we ourselves are far from holding any questionable opinions, and that, moreover, his confessor, the Père de Valois, is perfectly safe as to Quietism ?"x

Fénelon himself wrote a week later to Mme. de Maintenon :-

$$
\text { "March 7, } 1696 .
$$

"Your last letter, Madame, which seemed likely to grieve me much, comforted me exceedingly, for it showed me your thorough kindness, which was the only thing I was anxious about. If I were capable of sanctioning a person who taught a new gospel, I should have a horror of myself as devilish; I should deserve to be deposed and burnt, instead of borne with, as you kindly do! But I may very innocently be mistaken as to a person whom I believe to be holy, because I believe that she has never intended to write or teach anything contrary to the doctrine of the Church × Correspondence, vol. vii. p. 224 . 
Catholic. If I am mistaken as to this, my error is innocent; and as I never shall either speak or write with a view to authorise or excuse this person, any error would be as entirely a matter of indifference to the Church as it is of innocence to myself. I ought to know Mme. Guyon's real opinions better than all those who have examined and condemned her, for she spoke with more confidence to me than to them. I examined her most severely, and perhaps went too far in refuting her. I never had any predisposition in favour either of her or of her writings, and never saw anything extraordinary in her to prejudice me in her behalf. She explained all her sentiments and experiences with perfect freedom and openness to me. It is not a question of technical terms, which I do not undertake to defend, and which matter little in a woman, provided her meaning be catholic; at least that is what I have always thought. She is naturally given to exaggeration, and is careless in her expressions ; and moreover, she is trusting to excess with those who question her. This is clearly proved, since M. de Meaux has repeated things to you as impious which she had confided humbly to him under the seal of confession. I think nothing of her pretended prophecies or revelations, and I should think little of her if she esteemed them highly. A person who is really given to God may say offhand things which arise in her heart, without build- 
ing or meaning others to build upon them. Such things may be of God (for His Gifts fail not), but they may be mere empty imaginations. The way by which we love God solely for Himself, entirely renouncing our own selves, is a way of pure faith, which has nothing to do with miracles and visions. Nobody is more cautious or sober in this matter than I am."

The Archbishop then goes through some of the extravagances of which Mme. Guyon was accused, many of which he had never heard of before, and which he believed were not meant to be understood literally. If she said such things advisedly, he should call her a most absurd person, and find no words strong enough to express his disapprobation. ${ }^{\text {I }}$ As to teaching with presumption, he remarks that there are ways in which a woman is permitted to teach, i.e. by giving counsel on matters within her own experience, and with all due submission to authority. All superiors of religious communities are bound to teach in this way. If Mme. Guyon had outstepped this limit, she ought to be charitably checked, without being necessarily condemned. Women

2 Bossuet made great capital of some of these extravagant ex. pressions (see Life, p. 389), and was eager to have it believed that Fénelon endorsed them. He, however, repudiated all such, not only in private letters, such as the above, but in his published Answers to Bossuet's writings on Quietism, in which he says that Mme. Guyon was mad if she spoke thus seriously, but he believed her to be only ignorant, indiscreet, and given to exaggeration; he believed she meant well. 
cannot teach or decide with authority, but they may edify, counsel, and instruct on matters already authorised.

Fénelon goes on :- "Permit me to say, Madame, that, after appearing to accept our view of this woman's innocence, you went over to the opposite opinion suddenly. From that moment you mistrusted me as obstinate, and you closed your heart against me. People who wanted to make way with you, and become necessary to you, implied in an underhand fashion that I was deluded, and might prove a heresiarch. Various methods of unsettling you were brought to bear; you were struck, and you passed from excessive confidence and trust to excessive alarm and displeasure. All our troubles spring from this, that you have not ventured to follow your own light and your own heart. . . . If you had spoken openly and trustfully to me, in three days I would have quieted all the excitement in Saint Cyr, and brought all into perfect submission to their pious Bishop. I would have caused Mme. Guyon to write precise explanations of whatever seemed questionable or exaggerated in her books; and these explanations or retractations (call them which you please), made voluntarily and in freedom, would have had much more effect in convincing people than papers signed in prison, or rigorous condemnations made by people who certainly did not understand the subject 
when they promised you to censure her. This done, I would have seen that Mme. Guyon retired afar, wherever you wished, pledging herself to discontinue all intercourse on spiritual subjects. It has not pleased God that so natural a course should be taken. Nothing has been proved against her conduct save calumny; she can only be accused of an indiscreet zeal, and a foolish way of speaking about herself. As to her doctrines, even were she honestly mistaken, is that a crime? But is it not natural to suppose that a woman, writing unguardedly before the outbreak concerning Molinos, might exaggerate her experiences, and not appreciate the due weight of words? I am so convinced that she meant no harm, that I would undertake now to make her give a perfectly clear and precise explanation of all her belief, as within rightful limits, and as detecting what outsteps them. Such an explanation would tend to undeceive those whom she is supposed to have infected with her errors, and to discredit her in their eyes if she appears to condemn what she had before taught. Perhaps, Madame, you will imagine that I make this proposal with a view to her release. Not so. I would engage to obtain such a precise explanation and refutation of all her condemned errors without taking her out of prison. I would not see her; I would only write to her,-letters which you should see, and which should be examined 
by the Bishops, - - her answers passing through the same channel, and then let what use you please be made of these explanations. Let her remain in prison. I am content if she stays there till her death, if we never see or hear of her again. I do not think that you consider me a coward, a liar, traitor, hypocrite, or a rebel against the Church. I swear before God, my Judge, that these are the deliberate convictions of my heart. If I am under a delusion, at least it is one free from malice, a pardonable delusion, which can hurt no one, and give no scandal, neither can it give any sanction either to Mme. Guyon's errors or to herself. Why then, Madame, should you close your heart to me, as if I were of a different religion to yourself? Why fear to talk of God with me, as though you were conscientiously obliged to avoid seduction? Why imagine that you cannot agree with me, and have a quiet heart? Why undo what God had so visibly done? . . . .

"If I thought that you were still of the same mind as when you wrote last to me at Cambrai, saying that you so much wished to receive my letters, I should write to you with my former ease, and I think that you would not find them poisonous. I was delighted last Monday to see that you still retain your taste for S. Francis de Sales' works. . . . All that I say to satisfy you, Madame, is said without interested motives. I seek nothing from you but your kindness. I cannot 
lightly let those bonds be broken which God has made for His own Service."

Tronson returned the papers Fénelon had sent him in about a month's time, through the Duc de Beauvilliers; he was ill, and said that he was not equal to weighing and discussing them then, but that he accepted them willingly, as the Archbishop of Paris found no fault in them. An active correspondence was kept up all through this year between all the chief actors in the matter. Fénelon drew up an act of submission, which he proposed Mme. Guyon should sign, declaring in the strongest terms her absolute rejection of all the errors condemned in the Articles of Issy, and this was discussed, added to, and diminished, as if it had been a diplomatic treaty affecting the peace of Europe! The Ducs de Beauvilliers and Chevreuse took a vigorous share, and probably all concerned were conscious of the truth of what the latter says in a letter to M. Tronson, dated August 18, 1696, that Mme. Guyon personally was not the object of his anxiety (although, believing her to be innocent, he would gladly be of use to her), but other and greater persons, who were aimed at beneath this cover.

On the 28th of August Mme. Guyon finally signed an act of submission, which, though retaining the form of that prepared for her by Fénelon, was doctored 
considerably by the other side, and added to at some length by Tronson. She wrote the same day to him, saying that she had followed his advice blindly, and signed without reserve. $x$

From this time Mme. Guyon personally ceases to fill any important place in the ever more and more active strife. She remained in the Bastille till r $70 \mathrm{r}$, poor thing! and then, at last, a spirit-broken, worn-out woman, spent with trouble and physical infirmities, she was allowed, at Cardinal de Noailles' intercession, ${ }^{2}$ to go and end her days in comparative peace with her daughter, Mme. de Vaux, at Blois. There she led a quiet and unnoticed life, devout and humble, without seeking to make herself conspicuous, until I 7 I 7, when she died, having outlived her most illustrious friends and foes, and consequently, as Saint Simon says, her death attracted but little attention. 3

Fénelon never saw her again. Indeed, it does not appear that he ever saw much of her, ${ }^{4}$ and his corre-

${ }^{x}$ Correspondence, vol. ii. p. 282.

2 "Les amis de Mme. Guyon furent redevables à la charité du Cardinal de Noailles, qui la fit sortir de la Bastille, où elle était depuis plusieurs années sans voir personne, et lui obtint la permission de se retirer en Touraine."-Mémoires, vol. vii. p. 26.

3 Ibid. vol. xxviii. p. 124 .

4 “'Je n'ai vu ni pu voir bien souvent Mme. Guyon. Mon principal commerce avec elle a été par lettres, où je la questionnais sur toutes les matières d'oraison."-Correspondence, vol. vii. p. 457 . 
spondence was entirely on the religious questions afloat. As soon as she became a subject of discussion and controversy, he discontinued his correspondence, as well as the slight personal communication he had had with her, he himself says in a letter to Cardinal de Noailles ${ }^{x}$ (and had the assertion been inaccurate, there were plenty of people ready and glad to refute it), in order to leave no ground for alarm among those with whom he was concerned,-alluding, of course, to his position with respect to the King's grandsons and to Saint Cyr.

Only such a man as the Abbé Jacques Bossuet, and probably even he only in the almost insane heat of blind spite and controversy, could have ventured to insinuate that anything unworthy of the noble-hearted Archbishop had ever contaminated his compassionate friendship for the poor ill-used woman, who, tête montée as she probably was, was certainly earnest in her devotion and desire to serve God. Fénelon's best friends and most faithful adherents did not think the cowardly charge worth refuting: neither do we. His life and actions are sufficient testimony to the motives which influenced him in this as in all other circumstances. "Unto the pure all things are pure."

$\therefore$ Correspondence, vol. vii. p. 457. 


\section{CHAPTER IV.}

THESE stormy years have been so fully dwelt on 1 in Bossuet's Life (after all, is there not often much more to be said concerning those who offend than the offended ?) that it may be allowed us not to dwell at great length upon them here. Bossuet wrote his attack on Mysticism, called Instruction sur les Etats d'Oraison, ${ }^{x}$ and invited Fénelon to examine the MS. This bore a friendly appearance, but it soon became evident that the real object was to extract what would be a self-contradiction from Fénelon, and he felt obliged to decline expressing his approval of the work. There are many letters concerning this subject, together with a Mémoire which he drew up, and read to the Archbishop of Paris, the Bishop of Chartres, M. Tronson, and the Ducs de Beauvilliers and Chevreuse, at Issy, August 2, 1696, they all expressing their entire satisfaction with it. Writing IEuvres de Bossuet, vol. xviii. 
early in September to Mme. de Maintenon, Fénelon says:- "I had said [to the above-named persons] that I could see no shadow of difficulty between $M$. de Meaux and myself as to the root of the doctrine, but that if he intended to attack Mme. Guyon personally, I could not approve it. . . . On opening his papers, I found them full of a personal refutation." : These friends then urged Fénelon to write a book which should give to the public a full expression of his own mind on the mooted subjects; and the result was the Maximes des Saints sur la Vie Intéricure, which, so far from allaying the storm, caused it to break forth with tenfold fury.

As has been already said, it is difficult now to realise how such a fierce storm could have been raised over such a book, written by such a man-a book treating solely of the most solemnly sacred subjects affecting the soul and God. Strange it is to see men of learning and piety mingling in the strife with selfseeking politicians-hard words, cruel imputations, and bitter calumnies recklessly tossed about, as if there were no future day in which all these things should be brought to judgment! Looking calmly back upon the turbulent scene, all the eager, feverishly excited actors in which have so long been laid in their graves-from the King, who was trying to atone I Corresfondence, vol. vii. p. 286. 
for a life of profligacy by a few years of bigotry, and the Pope, whose conscience and heart were with the accused Archbishop of Cambrai, though he dared not withstand the menaces of the wrathful Grand Monarque, and boldly say so; - to the fawning, passionate Abbé Bossuet, who afterwards feasted and bragged during the Lent when his Uncle of Meaux lay dying, and the cruel, treacherous Phelippeaux, who blackened his colleague's character when it suited him to do so unsparingly,-looking back, I say, on Pope and King, calumniator and calumniated, all have passed away, and "it is a very small thing" to them now what man's judgment of them has been or is. But, out of respect to truth and honesty, we must emphatically say that no one can read through the mass of letters concerning these events, whether from antagonists to their opponents, or internal letters from the respective promoters to their own chiefs, without keenly appreciating the difference of the tone adopted by Bossuet and all his adherents from that of Fénelon and his correspondents. There is no bitterness, no spite, no defamation to be found in the Cambrai letters; and while we must honestly grant that for Bossuet's sake it were a good thing if the whole correspondence had perished, it is not possible to say the same of Fénelon's. One's admiration and love for him does but increase as one follows the patient, 
humble, unselfish spirit in which he acted, spoke, and wrote throughout.

When the Maximes had been written, Fénelon sent the MS. to the Archbishop of Paris, saying :-

$$
\text { “ Oct. } 17,1696 .
$$

"There is no hurry, Monseigneur, about publishing this. You know better than any one what has led me to write it. My object was to explain thoroughly a system which has never been rightly explained or understcod. I have made many repetitions, in order to avoid whatever could be equivocal in handling so delicate a subject, wherein people are so suspicious. .. . I have done what I believe to be my duty, and leave the rest to God. . . . I do not care about my work. I am not even anxious about the truth; God will care for it. . . I I give my MS. up to you in the most absolute good faith, to suppress, cut short, correct or add what you may think necessary. As to the argument, I am not afraid of the Schoolmen's criticisms; on the contrary, the more precise a theologian and strict metaphysician any scholar is, the more he will see that my argument follows an inevitable chain, and puts the true limit to spirituality, so as to hinder subtle illusions. On one side examine this mass of passages from the Saints, and on the other my arguments, and you will see that the latter 
tend to modify the passages, and bring them to a harmonious doctrine. It is very easy to handle this matter superficially, to soften and smoothe, and give a continual semblance of condemnation of Quietism to a work, in order to have the public on one's own side, but such a weak line would be acceptable neither to God nor man. . . . Once more, I wish neither to hurry nor to delay-it rests with you, Monseigneur. . . . The important point is that the work should be perfectly true. When you are satisfied that the doctrine is fundamentally correct, never mind the rest. . . A As to expressions, I will alter them as you may desire; or rather, I will accept whatever corrections you and $\mathrm{M}$. Tronson may make, and with this view I have left half of each page blank." ז

Fénelon wrote in the same language of absolute trust to Tronson, expressing his desire that some profound theologian, known to be a pious man and not a partisan, should also examine his book. In a letter, dated Oct. 30,1696 , he professes his entire willingness to suppress the book entirely if Tronson thinks it well. ${ }^{2}$

Pirot, a doctor of Sorbonne, who had been employed by de Harlay to examine Mme. Guyon, and who was known to be a great friend and admirer

× Correspondence, vol. vii. p. 300 .

2 Ibid. p. 31 7 . 
of Bossuet's, was chosen to examine the MS.; and after reading it carefully, he gave it his unqualified approbation, saying that it was worth its weight in gold. ${ }^{x}$ Fénelon had adopted the Cardinal Archbishop's few criticisms, and the Archbishop told the Duc de Chevreuse that he entirely approved of the book. $^{2}$

In short, if ever a man was justified in publishing a manuscript, Fénelon certainly was justified in bringing out his Maximes; and when leaving Paris in December, he left the MS. with the Duc de Chevreuse for publication, only desiring, at the Cardinal de Noailles' request, that Bossuet's forthcoming book might be allowed to appear first. The Duke thought this a mistake, and appealed to de Noailles to release Fénelon from the promise, to which he replied that de Chevreuse could do as he liked. Accordingly, at the end of January 1697, and before Bossuet's book appeared, the Maximes des Saints was published. A long letter from the author to Bossuet 3 recapitulates the whole history of the book. It is

I “. . . à l'Abbé Pirot, Chancelier de l'Église de Paris, et Professeur de Sorbonne, qui se chargea de le répandre, et dit à Hébert 'C'est un livre d'or I' "-DE LA BAUmelle, Mémoires, vol. iv. p. 78 .

D'Aguesseau repeats the saying: “. . . Le docteur Pirot, approbateur de cet ouvrage, qu'il appela un livre tout d"or."Euvres, vol. viii. p. 200.

${ }^{2}$ Correspondence, vol. vii. p. $347 . \quad 3$ Itid. p. 359. 
singularly temperate in its tone, and at the end Fénelon says :- "If I hear it said in the world that M. de Meaux complains of me, I shall answer I do not complain of him, and if he has any complaint to make, I think he would make it to me myself. ... It rests with you to decide the tone of our future intercourse; whatever will enable me to see you, listen to you, consult you, and respect you as ever, will be the most in accordance with my wishes and inclinations." This was written on February 9th, and on February $13^{\text {th }}$ Bossuet wrote to the Bishop of Chartres about the book in language which can only be attributed to bitter personal animosity, and a disturbed mind as to whether he would not be proved wrong; while the pious wish expressed that the whole business may promote God's Glory has somewhat of the "catapult" tone about it, followed as it is by the sharp sentence, "A great deal is made of M. Tronson's opinion, but I am not sure whether what you call his wisdom is not excessive caution." s

The book did, as it could not fail to do, excite a great deal of observation and talk, and Bossuet was eager to carry his unfavourable impressions to the King, ${ }^{2}$ already prejudiced against Fénelon; a

Correspondence, vol. vii. p. 374 .

2 D'Aguesseau and de la Baumelle both say that Pontchastrain -then Controller-General, subsequently Chancellor-was the first 
prejudice naturally increased when the Bishop of Meaux, who had his ear so entirely, besought his pardon, with a display of contrition, for not having sooner exposed the fanaticism of his colleague! In a letter from Madame de Maintenon to the Archbishop of Paris, she says (Feb. 21, 1697):- "I have seen our friends [Fénelon and de Beauvilliers], and we were all very much embarrassed. I had a moment's private talk with the Archbishop of Cambrai. . . . $\mathrm{He}$ told me that Père de la Chaise had given him an account of a conversation he had had with the King, after which he could not but speak to his Majesty. I assented to everything; but from what I see of the King's mind, M. de C. will derive little satisfaction from such an explanation. . . . I have not inspired this opposition; it is genuine on the King's part against all novelties, but I foresee that it will be attributed to me." s

to denounce the Maximes to the King, which, however, the Duc de Beauvilliers had already presented to him. "Maurice le Tellier (de Rheims) écrivit sur le même ton à sa Majesté. Le roi ne crut pas qu'un ministre d'état et un évêque janséniste fussent de bons juges d'un livre de doctrine. Il manda Bossuet, qui lui jura que l'évêque et le ministre n'avoient dit que trop vrai. Le roi lui reprocha son silence sur une affais e si grave, ses liaisons avec Fénelon, son empressement à le sacrer archerêque de Cambrai. Bossuet se jette à ses genoux, gémit, pleure et demande pardon de ne lui avoir pas révélé le fanatisme de son confrère."-DE la BaUmelle, Mémoires, vol. iv. p. 69.

I Lettres de Mme. de Maintinon, vol. iv. p. go. 
Certainly any impartial observer, reading the contemporary documents of this period, could not but entirely acquit Fénelon of any ambitious designs, such as various persons have tried to impute to him. There is little doubt that if he had chosen to flatter Mme. de Maintenon, and yield to her wishes at this time, he would have preserved his position at Court. She thoroughly liked him, and her influence was allpowerful with the King, and would have been used at once in his behalf, but for the red rag of Quietism which was being perpetually brandished before her by Bossuet, and more gently and tremulously, though scarce less effectively, agitated by Cardinal de Noailles and the Bishop of Chartres. That Mme. de Maintenon herself did Fénelon justice in this respect is evident from a letter of hers to de Noailles (July I3, 1697), in which she says, that were he not so firmly convinced of the truth of his principles, he would give them up from self-interest, but that she believes him perfectly honest in his misconceptions. ${ }^{\mathrm{x}}$ D'Aguesseau, reasoning from the point of view the world generally takes,-i.e., that a man never does anything save from interested motives, - - supposes Fénelon to have adopted his line in religious matters with a view to placing himself at the head of a party, and to "make devotion become the handle of fortune;" a I Lettres, vol. iv. p. I 10. 
most unlikely result, when the devotion adopted was in direct opposition to the King and all those specially influencing him, a conclusion at which d'Aguesseau himself arrives, when he observes that practically Fénelon's worldly fortunes were altogether blighted by it. ${ }^{x}$

It cannot be denied that the Maximes met with disapprobation from many of Fénelon's friends as well as his foes, as the following letter from Brisacier shows. The first sentence in it refers to a misfortune which had just befallen the Archbishop, his palace at Cambrai having been burnt down, with an absolute destruction of furniture, books, papers, and everything it contained. Fénelon was himself at Versailles, and he received the tidings with the patient calmness of a man whose knowledge of the Love of God was not technical only, but so real as to

× Euvres d'Aguesseau, vol. viii. p. 197. D'Aguesseau had a feud of "natural filial piety," as Cardinal de Bausset says, against, not Fénelon himself, but against the Duc de Beauvilliers, whom he supposed to have hindered his father from beconing Chancellor of France, " and it was difficult," says the Cardinal, "for so tender a son not to feel estranged from the Duke and all his friends. This sentiment influenced more or less all that he wrote concerning M. de Beauvilliers, Fénelon, the Bishop of Chartres, Saint Sulpice, and whatever in any degree appertained to this section of the Court and clergy." Every one ranged himself on the side of Port Royal or of the Jesuits in those days, and did all in his power to blacken the opposite party.Histoire de Fénelon, vol. ii. p. 20. 
make all earthly trials endurable. His devoted friend Langeron made haste to Versailles with the bad news, and found the Archbishop engaged in conversation so placidly, that he concluded the unwelcome tidings had not yet reached him, and began to break them as soothingly as he could. But it was unnecessary. Fénelon knew his misfortune already, and after thanking Langeron, and remarking that it was beiter it should be his house that was burnt than that of some poor peasant whose all would have been lost, he resumed the thread of his literaly discussion as calmly as if nothing had happened. ${ }^{\text {I }}$

De Brisacier writcs :-

$$
\text { “ } \mathrm{Feb} .28,1697 .
$$

"I only heard this morning, Moaseigneur, of the accident at Cambrai; I am told that nothing of your apartments was saved, and that the fire has not spared either your library or your own papers and manuscripts, which I regret most of all, for that is an irreparable loss. However bravely you may meet this misfortune, I must beg you to forgive my distress ; and if you will not allow me to mourn over a fire which must cause you inconvenience for long, and suffering to others, at least let me thank God for having so lifted you above the losses of this life, that you seem vulnerable only to what concerns the things of the next life.

${ }^{2}$ De la Baumélle, Mémoires, vol. iv. p. 83. 
"I cannot console myself, Monseigneur, under all that I hear said daily by all sorts of people, of every class, against a book bearing your name, and which, so soon as I saw its title and object, and the mode of its publication, threw me into the greatest consternation, by reason of my devoted attachment to you, foreseeing as I did the dangerous consequences to which it exposes you, independently of the criticism its doctrine will excite. Nor have my fears proved vain;-they are confirmed daily. As I have always been looked upon as one of your most faithful servants, and have been known before the publication of your book to defend you heartily from the suspicions cast upon you, many people think that now they have a right to ask me how you could venture to write upon so delicate a subject, and why your intimate friends did not dissuade you from doing so? People take pleasure in telling me a number of things about which I have myself uneasiness enough already; and in addition to what I see with my own eyes, I am told on every side of prelates not in the least prejudiced against you, of sensible abbés, zealous curés, learned doctors, superiors of secular and regular communities, laymen of weight, who enter into spiritual subjects,all such, however hitherto prejudiced in your favour, cannot help saying, publicly or privately, that you have few partisans in this matter. Indeed, practically, it is 
true that hardly anybody dares support you ostensibly or secretly, and your best friends, if they do not say so, are sorry to see you enter upon a career whence you can scarcely come out altogether satisfactorily, and upon which you were certainly not obliged to enter on behalf of God's Glory, which is more likely to suffer. Such, Monseigneur, is the anticipatory judgment of the public, which, in spite of myself, I hear from every one, go where I will. And trustworthy people from Court assure me that most of the courtier world is as much opposed to you as the world in general in Paris; so that, although hitherto there has been some restraint in speech, it is evident that it would take but little to bring about a great explosion, which one could not but exceedingly deplore for many reasons, especially with respect to the important offices you hold in Church and State.

"For myself, I only discuss the subject with a few intimate friends, most of whom are yours also. They are as much alarmed as I am, and their honest anxiety increases mine. You are not a common author, Monseigneur, and even were it a matter of indifference to others, it can never be so to me; but, unfortunately, it cannot be indifferent to anybody, and whatever concerns you must inevitably make a great stir. It will not do for a man of your position to be ever so little suspected as to his opinions. What would 
happen if it came even to worse than this? And can you use too much precaution to prevent such a disaster? I protest, Monseigneur, with sorrow and respect, that $\mathrm{I}$ am not writing out of any personal feeling, or at the instigation of any one whatsoever. Nobody in the world knows that I am writing, or what I have said. No one has prejudiced me, no one has urged me, no one suspects that I am presuming to take so great a liberty. Night is my only confidant. I have no motive save that of pouring out my heart sincerely and respectfully to a prelate, esteemed for his own sake and beloved by everybody, who, great man as he is, has given me proofs of friendship as acceptable as honourable to me. I have no wish to set myself up as a censor or a judge, or that this letter, written in the dead of night, and of which I keep no copy, should ever be seen by any eye but yours. My pen is guided by no critical spirit, but solely by a heart devoted to you, which groans before God at the prospect of all that may ensue.-Believe me," etc. etc. ${ }^{x}$

The Archbishop to whom his friends could write thus so honestly and faithfully, according to their judgment, was not likely to be an ambitious or selfseeking man. The very next day we find another intimate friend, the Abbé de Chanterac, writing to a

× Correspondence, vol. vii. p. 379. 
lady, ${ }^{x}$ that probably the reason of so much stir being made about Fénelon's book was, that he himself was so entirely sincere, and so deeply penetrated with the truths of religion, that few about Court could understand him or his mind; and the writer does not suppose that savans and courtiers, dried up with worldly influences, are any judges of the science of the Saints. More is the pity, he adds, that they should attempt to criticise it! M. de Chanterac goes on to say :"It is not possible for an unprejudiced person to say that this book favours the Quietists. I assure you that it condemns them more severely than the censure passed by Rome upon the sixty-eight Propositions [of Molinos]. . . The Jesuit Fathers take a very different view of this book; they approve, praise, and defend it, and so does every one well known for piety. All who have read it about here admire the elevation and extent of the author's genius, the beauty and facility of his simple yet grand style, the weighty evidence, precision, and solidity of his maxims and doctrine, combined with such entire disregard of self, and such childlike docility to the authority and decisions of the Church."

We find many letters on each side, decrying and exalting the Maximes; and many replies, chiefly to friends, from the author. One of the most interest-

I Mme. de Pontchat. Correspondence, vol. vii. p. 383 . 
ing of these is a letter to the celebrated de Rancé, Abbot of La Trappe, a close friend of Bossuet, who had disseminated some very virulent expressions of the well-known hermit against Fénelon. The reply is a marvel of gentleness and patience; Fénelon explains what his real opinions and views are-very different, of course, to those imputed to him-and ends by saying:- "I quite understand that I did not explain myself properly, since so enlightened a man, and one so versed in God's ways as yourself, has misunderstood me. If you had done me the honour to ask my meaning in the matters which scandalised you, perhaps I might have been so fortunate as to remove the difficulty-at all events, I should have tried to profit by your lights to correct myself. I shall still endeavour to do so, if you will charitably tell me what perplexes you, and remain with sincere respect," etc., etc. ${ }^{x}$

Returning to Paris, to find the storm bursting everywhere around him, Fénelon had an interview with Mme. de Maintenon, who was reading his book when he entered. "Here is a chapter," she said to him, "which I have read nine times, and I cannot understand it yet!"

"Madame," the 'Archbishop replied, "if you read it a hundred times, you will not understand it any I Correspondence, vol. vii. p. 519. 
better! All mystical writings are obscure, and the Court is not the best place in which to learn to understand them."

"Probably that is why such dreadful things are said about your book," Mme. de Maintenon answered; "but when I recollect that you wrote it, I feel reassured in spite of the fuss!" s

However, she asked Cardinal de Noailles' opinion of the book, and the following letter is important, considering how strong a part the Cardinal was persuaded into taking against it later on. He wrote :-

$$
\text { " March I, } 1697 .
$$

"I return M. de Cambrai's book, Madame, with many thanks for your kindness in sending it to me. I have read it very carefully and thoughtfully, and am very much surprised not to find what has been so generally and loudly condemned in it. I have not found a single proposition, or an expression, or even a single word, which offends me. They must be more subtle critics than I am who find matter for objection and criticism in it-for one can hardly suppose that they have so confused matters as to condemn the author for the propositions he has only quoted to condemn :-it is not likely, considering how he has separated what he approves from what he

× De la Baumelle, Mémoires, vol. iv. p. 72. 
condemns. On the contrary, I can see nothing original in this book but what shows very correct theology, great insight into the interior life, and a very clear exposition of its most hidden mysteries, which the author must have acquired far more by experience than by reading books upon the subject. Certainly those who seek to condemn M. de Cambrai for this book must begin by condemning Saint Francis de Sales for his beautiful Traité de l'Amour de Dieu, inasmuch as the one is but a commentary on the other." $x$

The Cardinal goes on to say that the source of this criticism probably is to be found in the jealousy of authors, though at the same time he admits that it may be partly founded on the fact that Fénelon does not denounce the modern Quietists; and he expresses a doubt as to the book being useful at the present time, and in the present form. As to the question of time, the Cardinal probably forgot that he was one of those who had urged Fénelon to write it! But throughout this controversy poor Cardinal de Noailles was troubled with a very feeble memory as to what he had said a few days before!

Perhaps in consequence of this letter, Mme. de Maintenon sought another interview with Fénelon × Correspondence, vol. vii. p. 390. 
on the subject ${ }^{x}$ and Bossuet's book having by this time appeared in fierce antagonism, it was proposed (whether by Fénelon himself or by Mme. de Maintenon is differently stated by contemporary writers) that he should explain himself thoroughly in the presence of de Noailles, who had been concerned all through the matter, the Duc de Chevreuse, and Mme. de Maintenon. This conference took place at Saint Cyr, but little good came of it. Mme. de Maintenon grew more puzzled than ever, for de Noailles had been beset by Bossuet, of whom he was always afraid, and he hesitated and shrank from confirming his own words already written. De la Baumelle says that, at the conclusion of the interview, Mme. de Maintenon exclaimed, "Argue on, Messieurs, and if you can, be both of you right!"

Mme. de Maintenon writes (April 3, I697) to de Noailles that the King is very anxious to prevent the publication of a third edition of the Maximes. "You may rely upon it, Monseigneur," she goes on to say, "that this matter will not easily be calmed down, either at Rome, in France, or in the King's mind, and that everywhere people are alarmed for the Princes who are being thus educated. As to me, I am distressed and perplexed. I am so on my own account: I dread the results of this difference between two × De la Baumelle, vol. iv. p. 73. 
great prelates, should they proceed to extremities; I dread the line the King may take, for which he must answer to God; I have the same dread for you."

These remarks concerning the Princes were not mere gossip. The anti-Beauvilliers faction was hard at work to get not only Fénelon but the Duke dismissed. The latter wrote to Fénelon:-

$$
\text { "April 15, 1697. }
$$

"The attempt is to get rid of me, and it will succeed if Mme. de Maintenon continues as opposed to me as she now is. I am not conscious of deserving it, and I believe that God would have me abide at the post where $\mathrm{He}$ has placed me, altogether irrespective of any action of my own. . . . There never was a wider spread Court intrigue, or one more energetic against an individual, than this against me. They go so far as to put about that it is a terrible thing to see the Princes in the hands of the promulgators of a new religion."

One demonstration of this excitement was the dismissal from Saint Cyr of Mme. de Maisonfort and two other religious, Mmes. de Tour and de Montaigle, on the ground that they were followers of Fénelon. The King and Mme. de Maintenon, with the little Duchesse de Bourgogne, assisted on this

$$
{ }^{x} \text { Lettres, vol. iv. p. } 95 \text {. }
$$


occasion. The King himself harangued the Community on the danger of these new opinions, and afterwards wrote from Compiègne to the Superior, forbidding these ladies (who were great favourites in the house) ever to return or be admitted within its walls. ${ }^{x}$ Bossuet certainly did all he could to fan the flame by his writings and his works. Fénelon was especially hurt at being told by Hébert, the Curé of Versailles, that, before the assembled Court, Bossuet had stated that "M. de Cambrai had often told him that he was in the habit of using the pratique interieure of contrition for which the Molinists were condemned." Fénelon, who was the "most moderate of men" (says de la Baumelle in telling this story), could not restrain his indignation, and exclaimed, "If M. Bossuet really said so, he is most dishonest! I never spoke to him of my interior practices save in confession, and then I certainly never said anything of the sort !"

Perfectly alive to the energy and unscrupulousness which were now openly in the field against him, Fénelon determined to refer the question to the Pope; and accordingly-determined to do everything as far as possible so as to avoid giving offence-he applied through the Duc de Beauvilliers to the King for leave to do this, even sending a rough draught of his proposed letter for his Majesty's perusal. On the I6th × De l.a Baumelle, Mémoires, vol. iv. p. $89 . \quad 2$ Ibid. p. 74 . 
April he received permission thus to appeal, and the letter, dated April 27, I697, was accordingly sent to Innocent XII. In it Fénelon explains the motives which led him to write the Maximes, i.e. that he saw how some persons were gradually inculcating pernicious doctrines concerning contemplation and the interior life, while others, who knew nothing of spiritual things, turned them into ridicule. "The abominable doctrine of the Quietists," he says, "was, beneath a pretence of perfection, gliding stealthily like a gangrene into various parts of France and Belgium, and writings, some incorrect, and others of a very suspicious character, were exciting the indiscreet curiosity of the faithful. For several centuries past sundry mystic writers, themselves holding the mystery of the faith with a pure conscience, had unknowingly favoured this hidden error; - they did so out of the excess of a tender piety, combined with a lack of caution in the use of terms, and a very pardonable ignorance of theological principles. This kindled the zeal of certain illustrious Bishops, and led them to compile Thirty-four Articles together with me, and also to pass sundry censures on certain little books, some passages of which, taken in their most obvious sense, deserved condemnation. It is, however, rare," he goes on to say, "that men fly from one extreme without falling into the other; and some persons have 
made this a pretext, contrary to our intention, for turning the pure love of the contemplative life into ridicule, as an extravagant chimera. Therefore I believed it well to point out the true mean, to separate the true from the false, that which is venerable and confirmed from that which is novel and dangerous; and that I have attempted to do according to my limited capacity. It is for you, Holy Father, to judge thereof, and mine be it to listen respectfully to you, the successor of Saint Peter."

This letter was sent to Cardinal Colloredo, to present to the Pope, and at the same time Fénelon wrote, enclosing a copy, to Cardinal Denhoff. ${ }^{2}$ The Holy Father and these dignitaries, as well as Cardinal Casanata, wrote back in affectionate terms; avoiding -as is common to official personages-committing themselves to anything in particular. The simple good faith in which Fénelon took the step of appealing to the Pope, and his remarkable personal humility and absence of self-seeking in the matter, are very strikingly shown in a letter of his to the Supérieure of the Nouvelles Converties, the Community of which he once had charge, a letter in which he advises her not to read his book! After some kind messages to a sick Sister, and a playful request to her not to die just

s Correspondence, vol. vii. p. 407. 2 Ibid. p. 405. 
now, but to wait till some future time when he might have time to visit her, Fénelon goes on to say :- "As to my book, I wrote it with an honest intention, and in submission to the Church. I only believe it to be sound because I find a certain number of excellent theologians who believe it to be so, and conformable to the writings of the Saints. Those who attack it interpret it in a sense altogether different from mine, while yet they acknowledge that my interpretation is thoroughly catholic. All the same, my dear Sister, the stir made by so many admirable people is sufficient reason for you to suspend your judgment. I myself think it a duty to mistrust even my most clear thoughts, and to redouble my attention in listening to the thoughts of others, and in explaining myself more clearly. Moreover, supposing my book to be sound, it is not suitable to every one; it is not mere ordinary religious reading intended for all good people. It is only written for those who direct others, and with respect to souls of the class alluded to in it. So, for all these reasons, my dear Sister, I come to the conclusion that you had better neither read my book yourself nor give it to the person you mention to read. It would be mere curiosity, and you know how strongly I feel that curiosity ought not to be indulged in religious reading." $x$.

$\therefore$ Correspondence, vol. vii. p. 440 . 
Meanwhile the Bishops were fussing and frettingBossuet, in stedfast opposition, ${ }^{x}$ preparing a pamphlet against the Maximes (which he constantly promised to show Fénelon in MS., but without ever doing so), de Noailles pulled hither and thither according to the pressure put upon him, and Godet-des-Marais endeavouring to induce Fénelon to retract his book, as the only means of setting things straight. Tronson joined with the Bishop of Chartres in this wish. Fénelon writes (May 2, I697) that he has read M. de Chartres' criticism with great satisfaction, for he thinks it would be impossible to do more to upset his teaching than the Bishop has done, and yet he does not feel it in any way shaken. ${ }^{2}$ The three Prelates met and erected themselves into a tribunal, examining the book, and picking out all that they thought censurable, having done which, they invited Fénelon to confer with them upon it. Great pressure was put upon him to consent to such a course, the King himself, at

x "Bossuet frémit de se voir enlever sa proie, soutient que des explications sont des faux-fuyans, veut une rétraction formelle, l'emporte sur le Roi, sur Mme. de Maintenon, sur le Père de la Chaise, sur toute la Cour. Paris, ne pouvant être juge du com. bat, raisonnoit sur les combattans. On cherchoit la cause des animosités de Bossuet et des répugnances de Fénelon. Le grand éclat de M. de Cambrai éblouit M. de Meaux ; il lui semble que chaque louange qu'on donne à un autre est un larcin qu'on fait à sa gloire," etc., etc. -DE LA BAUMELLE, vol. iv. p. 75.

aCorrespondence, vol. vii. p. 420. 
Bossuet's instigation, urging it through de Beauvilliers. Fénelon wrote (May I r, r697) to the King in consequence, expressing his perfect willingness to resume the examination of his book with the Archbishop of Paris, Tronson, and Pirot, although he denied that the Archbishop had any authority to judge it ; and also remarked that, while various other people had seen Bossuet's promised remarks, he had not done so, and therefore the delay did not rest with him. ${ }^{x}$ He could not, consistently with his dignity, admit Bossuet into the discussion, and both the King and de Noailles seemed to admit this.

The discussions began, but Fénelon was in a difficult position, for the Bishop of Chartres was always desiring explanations, yet never able to fix on what explanations were wanted; de Noailles was frightened, and would have let it all alone, if he had not been continually brought up to the charge by Bossuet, of whom he was most thoroughly afraid; and Bossuet himself, behind the scenes, was altogether impracticable. He communicated his pamphlet to all save Fénelon, who thus was practically excluded from the real discussion on his own book by the very person he himself wished to exclude. ${ }^{2}$ After a time, finding

$\checkmark$ Correspondence, vol. vii. p. 425 .

2 "Ainsi la personne que j'avois exclue de l'examen de mon livre m'en a exclu moi-même, et mon affaire s'est traitée sans moi, par des personnes qui n'auroient dû s'en mêler qu'avec moi et à ma prière."-Ibid. p. 445 . 
that this course was not likely to conciliate his episcopal brethren generally, Bossuet proposed to invite Fénelon to assist at the sittings; but his letters to his nephew the Abbé Bossuet at Rome prove that this was only done when he and the two Prelates who acted under his directions had already decided on the points he considered censurable, the precise qualifications to be made, and the satisfaction Fénelon (according to them) ought to make to the Church by a formal retraction. Bossuet, moreover, wrote a paper, of a most offensive character, which he desired de Noailles to communicate to Fénelon, saying that the three Bishops felt themselves constrained to speak, lest the Church at large should suppose they countenanced the "false doctrine" of the Maximes, with other equally strong expressions, concluding with an assertion that, from beginning to end, the book was neither more nor less than an apology for Quietism. And as if this was not insulting enough to a brother Bishop, Bossuet added, that the explanations offered by Fénelon were inadmissible, because they were not sincere!

Fénelon, therefore, most justifiably continued to refuse to meet Bossuet in conference; Mme. de Maintenon had been persuaded that the Bishop of Meaux was essential to the work, and matters were at 
a sort of deadlock. In a very long letter of June 8, r697, Fénelon puts all the facts connected with his book before the Archbishop of Paris. At the beginning he begs de Noailles not to take to himself any of the complaints the writer is forced to make, as he imputes none of the injustice done him to the Archbishop, who has been forced to act as he has done $d$ regret. "As to M. de Meaux," he says, "you know better than any one what has been his line throughout, and what mine." Fénelon recapitulates the course of events:- "You cannot but remember, Monseigneur, that I first offered Mme. de Maintenon at Saint Cyr, in your presence, and subsequently told the King, that I would renew the examination of my book with the persons who had already examined it, i.e. yourself, M. Tronson, and M. Pirot. The only point to be considered was the doctrine essential to faith, and my main condition was the exclusion of $M$. de Meaux. I have in my hands the minute which the Duc de Chevreuse was good enough to communicate to you, and which you accepted in every particular. . . This exclusion of M. de Meaux was not caused by resentment, but by the painful necessity to which he had reduced me of having no dealings with him, after the conduct he has pursued towards me for several years. I had even been con- 
strained, since the publication of my book, to write a detailed account of his proceedings towards me, which the Duc de Chevreuse read to him, and of which he could deny no particular. Although I had very strong reasons to give, and an urgent interest in justifying myself against his attacks, yet I chose to be silent, and let myself be condemned. I am ready to publish that document, if unfortunately I should be compelled to do so.

"M. de Meaux was to communicate his remarks to me, as he promised the Duke, after which all he had to do was to leave you alone. I was myself to reexamine my book, profiting by the counsels you might be so good as to give me, after we had had a careful discussion, of doctrine only. Such were the precise terms of our engagement. . . More than four months have elapsed without the fulfilment of M. de Meaux' promise. First, he said that I only should see his comments upon my book; then he added, that he should show them to you, Monseigneur, and to $M$. de Chartres. He has used this pretext gradually to hold meetings, which you thought it necessary to allow of under the circumstances, and which, far from your intention, have given some strange revelations to the world. I have yet to receive M. de Meaux' promised remarks, and you yourself held that I ought not to wait for them, when you informed me what 
were the chief subjects of criticism in my book, which I noted down in your presence. Thus the very person I had excluded from the examination of my book excluded me myself, and my business was dealt with without me, by the persons who should only have interfered hand in hand with me, and at my request. I was kept in suspense, precious time was lost, and I was the one man who knew least concerning my own affairs, while others were deciding the fate of my book. You alone, Monseigneur, showed a sincere disposition to treat me with consideration, and looked on with regret at what you could not hinder.

"Then, as soon as these meetings were ended, the matter was treated as concluded, and I was to be reclaimed as a culprit." [Here Fénelon goes through the technical course of the proceedings, proving their injustice by the Archbishop's and Pirot's own witness.] "Hitherto you have held no discussion with me. After so long a one with M. de Meaux, it is not just to come to a conclusion without hearing me. I cannot look upon the examination as finished when we have not even begun it. When you have patiently discussed everything with me, according to your engagement, and when we have gone into my explanations together, you will be in a position to give me suitable advice, and you will then see, Monseigneur, 
how much I wish to show you all possible deference and confidence.

"What is it proposed to do? They will not understand the meaning of my book, and they will not allow me to explain it. Can it be that they really fear to let it appear as it really is? I only want to show that its real meaning is such as is approved, but they will not allow it to have such a meaning." . . .

Fénelon goes through his defence, and clearly shows the injustice of his accusers. How far he was from intentionally teaching Quietism may be seen from his renewed affirmation :- "I do not fear the accusation of Quietism; I can speak so clearly upon that as to remove the faintest suspicion." $\mathrm{x}$

De Noailles and the Bishop of Chartres were greatly impressed with the force of Fénelon's remonstrances, and would probably have yielded to them, but Bossuet overpowered them. His own agent, Phelippeaux, says that he replied vehemently, "Do as you please; as for me, I will lift up my voice in spite of you. I will carry my complaint to Rome, and over the whole earth; and if I am left single-handed, I will work alone."

Always ready to concede if it was possible, Fénelon now even consented to confer with Bossuet, but upon three conditions only:-I. That there should be other

- Correspondence, vol. vii. p. 442. 
Bishops and theologians present. 2. That fair turns should be taken in speaking, and that questions and answers should all be committed to paper as they were made. 3. That Bossuet should not, on the strength of any such conferences, take to himself the office of examiner of the Maximes, but leave that, as already decided, to the Archbishop of Paris, Tronson, and Fénelon. But Bossuet replied with acrimony that such conditions would make any conference useless, and the whole thing came to an end.

Fénelon must have been driven nearly distracted among them all. On the I 4 th of July he wrote to the Abbé de Chanterac that he purposed to go himself to Rome, if permitted, and wished to make such preparation as was necessary, saying that he was ill and feverish from worry and want of sleep, adding touchingly, "I cannot take quinine; nothing but rest can do me any good, and that God denies me. Pray for me."

On July 2 and he wrote to de Noailles, enclosing a document to be read to the King and to Mme. de Maintenon, adding that it was out of respect to the latter that he had refrained for several months from attempting to see her. "My conscience will not allow of my obeying her wishes, and I should only distress her by trying to remove the injurious impressions given her concerning me." On the $25^{\text {th }}$ he wrote to Louis XIV.,

${ }^{4}$ Correspondence, vol. vii. p. 498. 
asking permission to go himself to Rome, pledging himself to enter into no other business than that concerning his book, to live as quietly as he did at Versailles, and to return immediately on receiving a positive reply from the Pope. But his cause was already prejudged, and Louis XIV. had, at Bossuet's instigation, written an urgent letter to the Pope, calling upon him speedily to condemn the Archbishop of Cambrai's book. ${ }^{x}$ How much diplomacy and party spirit was at work at this time is illustrated by the statement made by de la Baumelle, that at the same moment Père de la Chaise wrote to Cardinal Jansson, as from the King, begging him to protect the interests of the Maximes at Rome. Louis XIV. only knew of this when the Cardinal wrote back to say he would do as his Majesty wished, and the King had a violent scene with the Jesuit Father in consequence!

July 29 th, Fénelon wrote again, this time not to the King, but to Mme. de Maintenon, pressing that he should be allowed to go to Rome, and pointing out how evasively he had been treated. "I should go," he says, "quietly, hoping to be undeceived if I am in error, and to find, at all events, what I cannot find in France,-I mean some one with whom I can come to

x There is a difference in the date assigned to this letter by different editors, but, anyhow, it was written between the r6th and 26 th of July. 
a definite conclusion." $\mathrm{He}$ wrote at the same time to the Nuncio, and both these, as well as other letters of the same date, cannot but strike any reader with their extreme gentleness and simplicity. But Fénelon was still to be thwarted and hindered. On the Ist August, Louis XIV. wrote in a harsh, unfriendly style, merely saying that he did not see fit to allow the Archbishop of Cambrai to go to Rome himself; he might send whatever was necessary to defend his book, but he was to go to Cambrai directly, without lingering in Paris more than was absolutely necessary; and the letter concluded with a rough order to Fénelon not to leave his diocese until further orders. Practically this was a sentence of banishment: Fénelon knew it was so intended, and it proved such in fact. He never returned to Paris-never saw either the King or Mme. de Maintenon again.

That same day, immediately after receiving Louis XIV.'s letter, he wrote to Mme. de Maintenon :-

\section{"A Versailles, Aug. I, 1697.}

"I shall leave this, Madame, to-morrow, Friday, in obedience to the King. I would not even pass through Paris, if I were not at a loss where to find a fit person to send to Rome, who would be willing to undertake the journey. I return to Cambrai, in heartfelt submission, zeal, gratitude, and attachment 
to the King. My greatest regret is to have annoyed and displeased him. No single day of my life shall I fail to pray that God may fill him with His Grace. I give myself up to be crushed more and more. The only thing I would crave of his Majesty is, that the innocent diocese of Cambrai may not suffer for the faults imputed to me. I ask protection for the Church only, and even in that I merely ask not to be hindered in such little good works as my present circumstances allow me to do as a pastor. I have nothing further to say, Madame, save to ask your forgiveness for all the trouble I have caused you. God knows how keenly I feel it. I will never cease to pray that $\mathrm{He}$ Alone would fill your heart, and all my life I shall remember your former kindness to me as vividly as if it had not ceased, nor will my respectful attachment to you, Madame, ever alter." s

Always considerate for others, however little consideration he might meet from them, Fénelon even abstained from visiting his dearly-loved Saint Sulpice - which he was never to see again-and M. Tronson during this his last sojourn in Paris, lest the malice of his enemies should wrest even such an ordinary event to the hurt of the Community. In a few touching lines of farewell, he says :-

'Correspondence, vol. vii. p. 523. 
"I refrain from coming to embrace you, that I may be sure I in no way commit you. I revere and love you too much not to be more careful for your interests and those of your Community than for my own-and now my enemies are not satisfied with attacking my book, but no pains are spared to blacken me personally. The Archbishop of Paris, who professed such good intentions, now adopts $M$. de Meaux' tone, and says that for the last four years he has been trying to draw me from my errors, which are still more weighty in myself than in my book. They give the world to understand that it is because of these deep-seated and long-standing errors, concealed under smooth language, that these Bishops are obliged to deal with me in a rigorous fashion, which would not be used towards another man, in order to avoid all explanations, and force me into a retractation. I know that Mgr. de Paris joins in this accusation, and that he is going to write to the Pope, in concert with MM. de Chartres and Meaux, that they feel themselves conscientiously bound to accuse me to him, as a man who for years they have known to hold all the errors of Quietism.

"You know that I have placed all my original writings in your hands from long before the time when they accuse me of having gone astray, and I have 
altered in nothing since. ... M. de Meaux says that my book and my explanations do not agree, and that my real opinions are much worse than anything I have said in my book. I should be glad, if it would not commit you, for you to give again precise testimony as to facts to M. de Chartres. I am leaving for Cambrai, whence I shall write to Rome. I may perhaps write a plain, gentle letter to M. de Meaux, to clear up matters of fact and doctrine, in which he represents me as a 'fanatic and hypocrite.' Pray for me,-I need it greatly in my troubles,-and continue to love one who is ever full of affection, confidence, gratitude, and veneration for you." ${ }^{2}$

A few lines written on his first arrival at Cambrai to $M$. de Brisacier continue to prove the gentle, unirritated spirit with which Fénelon accepted the King's most harsh and unjust discourtesy, the malignity of which he was far too penetrating not thoroughly to understand.

$$
\text { "Cambrai, Aug. 9, } 1697 .
$$

"I hasten to give you the tidings you desire; no one could feel your kindness more cordially than I do. It seems to me that true faithfulness to grace is best proved by steadily facing one's actual duties, and

'Correspondence, vol. vii. p. 541. 
closing one's eyes to whatever may be a snare of self-love. 'Sufficient unto the day is the evil thereof.' I am content to accept my daily bread; anything else would be a temptation.

"The people here are sensible and well-disposed; they are not at all courtier-like, for which I am very glad; they have neither courtly politesse nor its vicious refinements. I hope they will appreciate my good-will. Pray for them and for me, my dear friend, I intreat you, and I would ask the same of $M$. Tiberge," etc.

While the great Archbishop betook himself thus quietly to his distant diocese, where he lived the life of a true pastor and saintly Father of his people, his friends and foes were neither so quiet nor so meek. Mme. de Maintenon was especially disturbed. Probably her natural good sense and right feeling told her that she had acted an unkind and unworthy part towards one whom she had often called and honestly believed to be a saint. Later on she herself told a friend $=$ that she was so much distressed, that the King, although vexed with her about the matter, could not help exclaiming, "How now, Madame! are we to see you worried to death about all this!"

- Correspondence, vol. vii. p. 546 .

2 Entretiens. Mémoires, vol. vi. p. 191. 
The King's letter to Innocent XII., dictated by Bossuet, has been already mentioned, and on August 6th the relentless Bossuet made his two feebler colleagues sign a "Declaration of our opinion concerning the Maximes des Saints," which, with the King's sanction, was sent to the Papal Nuncio, Delfini. It is noticeable that in this declaration one condemned proposition was simply a printer's error!

Probably no one felt a keener grief than the Duc de Bourgogne, whose affection for Fénelon never wavered through the years that followed, even when it involved the displeasure of his royal grandfather. Now, when he heard that the sentence of exile had been passed (for such it was, and such every one felt it to be), the warm-hearted boy threw himself at the King's feet, intreating that he might not be separated from Fénelon, and pleading the strict orthodoxy of his own education as a witness to his master's teaching. The King seems to have been pleased at the demonstration of character made by his grandson, but probably his prejudice against Fénelon was rather confirmed by this fresh proof of the strong influence the Archbishop had obtained over the Duc de Bourgogne, and he repulsed the boy, with assurances that he was not his own master, and could not act upon feeling;-it was a question of theology, which M. de 
Meaux understood better than they did. However, he so far yielded, that the title of Preceptor was not taken from the Archbishop of Cambrai then, and the young Duke was in a measure pacified.

Fénelon was one of those rarely-gifted people, whom to love is an honour and privilege to all fortunate enough to be near them, and now, in his day of disgrace, his friends held closely to him, and were proud of his friendship. Foremost among these was the Duc de Beauvilliers, who, with his whole family, remained as devoted to the Archbishop as when he had been the idol of their choice gatherings in the Hôtel de Beauvilliers. The King did his best to separate them; he sent for de Beauvilliers, and threatened him with a like fate to that of his friend, declaring somewhat pompously, that inasmuch as he was responsible to God and to the whole kingdom for the purity of his grandson's faith, he could not but look upon the Duc de Beauvilliers' intimacy and close connection with the Archbishop of Cambrai, whose doctrines were under so much suspicion, with the greatest anxiety. The Duke replied that he was perfectly alive to the fact that it was at his recommendation that Fénelon had been appointed to the Preceptorship, and that he had never for an instant regretted it: they had always been friends, and would ever be, he hoped. But the King need fear nothing 
as to the Duc de Bourgogne's education; so far from having been infected with Quietism, he did not even know what it meant. The Duke concluded by saying, with dignity and feeling, "Sire, you have placed me where I am, and you can displace me. I shall accept the will of my sovereign as the Voice of God, and I should retire from Court at your bidding, regretting your displeasure, but hoping to lead a more peaceful life in retirement." The King could not but have been impressed by the Duke's manly, uncompromising honesty; he accepted his assurances, and said no more. Meantime de Beauvilliers circulated a farewell letter he had received from Fénelon when leaving Paris, and throughout the remainder of their lives it was but a rivalry of generosity and affection between the two friends. Fénelon writes:-

$$
\text { "Cambrai, Aug. 12, } 1697 .
$$

"No one can feel more keenly than I do the distress I have caused you. The mere desire to relieve this would suffice to make me do the most painful or humiliating acts, but I have brought forward evidence to show how unfounded the objections to my book are. I did not find one theologian in Paris who, after quiet discussion with me, did not assent to all my opinions. The rest make a great 
noise, tear me to pieces, and abuse their authority. My enemies are some excited people, and a few wellintentioned persons, who have been overpowered by those who are acting so passionately. They have refused to let me explain myself, and insist on attributing errors to me which I detest as much as they do. This is outrageous, and in time all fair-minded people will have their eyes opened. As to me, all I wish is to bear my cross peacefully, and to pray for those who lay it on me. After carrying my cause to Rome, I shall accept whatever condemnation the Pope may pass. With God's Help, nothing shall be found in me but sincere docility, unreserved submission, and love of peace. Meanwhile I shall try to do my duty here, although all the obloquy cast upon me interferes with the good I might do in this very needy country. I pray that God may forgive those who so greatly hinder $\mathrm{me}$ in the performance of $\mathrm{my}$ duty.

"The theologians of this country are amazed at the harsh criticisms on my book made in Paris. What distresses me most is to offend the King, and make you incur the risk of losing his favour too. Sacrifice me, and be assured that my interests are nothing in comparison to yours. If my prayers are worth anything, you will soon feel all the peace and confidence and comfort which you need in your position. God 
knows with what affection, gratitude, and respect, I am," etc. ${ }^{x}$

De Beauvilliers wrote shortly after about some propositions made by the Bishop of Chartres, to which Fénelon returned a clear, manly answer, asking whether it was consistent with a kindly feeling towards a brother Bishop to uphold Bossuet in persistently attributing to him doctrines which he altogether repudiated. "From the first," he says, "I have offered to explain all that frightens M. de Chartres; and even if such explanations were not asked, I would make them, in order to enlighten and edify the faithful. But I abide firmly by what I have said from the beginning;-no weariness, or fear, or hope can ever induce me to say one word savouring of retractation. I would a hundred times rather unreservedly accept the most rigorous condemnation from Rome than utter one equivocal word giving an impression that I retract, because I cannot see a single proposition in my book which is not thoroughly and correctly explained in thirty other passages. So all negotiation on that score is useless. I must either be allowed to explain myself, or to wait for the Pope's judgment, to which I am as submissive as a little child. I do not know whether Rome will be particularly edified to find that my brethren have never been willing to allow me to explain myself.

Correspondence, vol. viii. p. 3 . 
"I must honestly confess that I do not know what to make of M. de Chartres. At first he seemed only to wish for an explanation, then that I should give up my book. He came back several times to the simple explanation, but never abided by anything. M. de Meaux always pulls him back again, and after so many changes I cannot depend upon his propositions. Moreover, I have learnt by experience that such dealings have made me lose precious time, and have worn out the King's patience, as if I were responsible for the irresolution and delay of others. Four or five times over the plans we had decided on together for explaining my book have been upset, in spite of the Archbishop of Paris. . . . I will write the short Instruction which $\mathrm{M}$. de Chartres advises as soon as possible, and promise a new edition, but that (with additions) I shall send to Rome, requesting the Pope to have it overlooked by the safest counsel. M. de Chartres hardly need be more rigorous or zealous against Quietism than the Pope and the whole Church of Rome, where these errors have been condemned from the birth; and when I offer to subject myself to the severity of the Inquisition which judged Molinos, surely the hardest to please might be content. If M. de Chartres is satisfied with this, we shall have entire peace, and may without delay edify the Church by our unity. From that moment I shall be 
of one heart and soul with him; and he need not league himself against me with $M$. de Meaux, who insists on making me a heretic in spite of myself. . . . But if he prevents $M$. de Chartres from standing firm, my mind is made up. I have only to bear my cross, to pray for those who oppress me, and strive to make up for the scandal given as far as possible by patience."s

There are many other letters written at this period, more or less in the same strain, all marked by their forbearance and calm, dignified language, even with regard to Bossuet, who was, and Fénelon knew it, now taking an active, feverish part in opposing him personally with every weapon at his command. A few lines written to Mme. de Gamaches, Aug. 20, I697, show the true source whence this calm gentleness sprang:- "It is no mere form of words to say that it is good to take up the Cross; - this is a Gospel truth which recoils in condemnation upon the head of those who preach it if they do not try to follow their own precepts when occasion offers. And that occasion has come to me now; so I must embrace my cross, I must perceive its use, and dread lest I lose the fruit thereof; I must try to bear it humbly, and not in any earthly strength. My only strength and help must come from God. I must Correspondence, vol. viii. p. 7 . 
seek to love those who calumniate me; I must pray for them, and be always ready to give up for peace' sake whatever I conscientiously can. . . . With such good intentions I am in peace. If I am mistaken, I shall be undeceived, and that is a great advantage; if, while meaning rightly, I have explained myself amiss, I shall be corrected, and I ought to be glad of that. Woe be to me if I shunned correction through a false shame! I owe more than most men to truth by reason of my office. All I regret is the scandal which this matter gives; and I do not think it is my fault that it was not put an end to almost as soon as begun. As to my humiliation, that carries its own consolation with it, for I know that it is a good thing to be humbled, and I need it more than most. I should be but too happy if my present position teaches me to practise some of the detachment and self-abnegation of which my book treats. A little while and the vain dream of life will vanish, and we shall be reunited in the Kingdom of Truth, where there is no more error, or division, or scandal, where we shall be filled with the Love of God, and share in His everlasting Peace. Meanwhile, let us suffer silently, and be trodden under foot, bearing the reproach of Jesus Christ, too happy if our disgrace tends to promote His Glory."x

\& Correspondence, vol. viii. p. 25. 
And Sept. 1, 1697, the Archbishop, after telling the Duc de Beauvilliers that they had just sung Te Deum for the taking of Barcelona, ${ }^{x}$ goes on to say:- "I am working on quietly here, dealing gently, so as to enable myself to work usefully. These people like me fairly well, because they find me quiet, even, and not proud; they do not think me harsh, self-interested, or artificial. They trust me, and our worthy Flemings, rough as they seem, are more crafty than $I$ intend to be. ... In the situation to which men have brought me, and where God permits me to be, I must be very careful, and suspend many good works, urgent as they may be, for just now nothing could succeed. If God chooses to use me in promoting them, $\mathrm{He}$ will disperse the storm which men have raised. They must answer to Him for all the good which they hinder, and for the scandal given to the Church. . . . As for the Duc de Bourgogne, I pray daily for him; it is all I can do for him now. People here are very curious to know whether I am banished. They ask my servants, but happily they have not asked me in plain terms. If it would be better, I am quite ready to make no mystery, but tell what my orders were. One must not bargain with God when $\mathrm{He}$ chooses to heap discomfiture and humiliation upon one. If $\mathrm{He}$ sees

I It had opened its gates to the Duc de Vendôme, Aug. Io, 1697 , after fifty-two days' siege. 
fit to complete my overthrow, so that I cannot do anything, I shall abide in His House, full of hearty good-will, though an unprofitable servant."”

It was war to the knife now on Bossuet's part, and chiefly on his, so far as one can judge by the numerous letters, mémoires, and other writings of the period.

"Two illustrious adversaries, rather equal than alike, were seen entering the lists," writes d'Aguesseau ;" "the one long deeply versed in the Church's science, and covered with laurels won in many a combat for her against heresy, an indefatigable athlete, whose age and past victories might have dispensed him from fresh wars, but whose vigorous mind was superior to his weight of years, and who retained much of his youthful fire; the other in the prime of life, less known by his writings, but not less famous for his eloquence and genius, nurtured and long trained in the subject of contest, thoroughly versed in the language of mysticism, capable of understanding and of explaining everything, and that plausibly. Friends for years before they became rivals; both to be admired for the purity of their lives, and loved for the kindliness of their deeds; both ornaments of the Court and of humanity itself; one respected as a setting sun, whose beams were ${ }^{\prime}$ Correspondence, vol. viii. p. 28. ${ }^{2}$ Euvres, vol. viii. p. 204. 
about to be quenched with majesty, the other looked upon as a rising sun, promising to fill the world with its brightness if once the unhappy eclipse now pending were passed away. A flood of writings issued from these fertile pens, which entertained the public, but saddened Churchmen, as they watched the division of two men, whose union would have been as glorious as useful, if they had known how to turn the arms wielded against one another to the overthrow of the Church's foes."

The Pope is said to have remarked that "Cambrai erred through excess of love of God, and Meaux from lack of love to his neighbour." 2 And hearing some Cardinals arguing warmly that Fénelon was damaging the grace of Hope and Bossuet that of Charity, his Holiness tersely observed, "Meanwhile none of you seem to find out that all the while it is Faith which suffers."

Bossuet fully realised the talent of the man he was seeking to overthrow. Mme. de Grignan asked him one day if Fénelon had really as much esprit as was said. "Ah, Madame! il en a, à faire peur!" was the reply. ${ }^{3}$

Euvres, vol. viii. p. 204.

2 "Cambrai péche par excès d'amour divin, et Meaux par défaut d'amour pour le prochain."-DE LA BAUMELLE, vol. iv. p. 103.

3 Ibid. p. 89. 
When Louis XIV. so abruptly refused to allow Fénelon to go himself to Rome, it became an important question who could best represent him. $\mathrm{He}$ selected the Abbé de la Cropte de Chanterac, who was connected with him through his mother's family, and who is characterised by Pirot as a wise, conciliatory, learned, and excellent man. $\mathrm{He}$ was a good theologian, and had specially studied the vexed question of the present day; he was personally unassailable in purity and devoutness of life, and he had the gift of discretion and tact, without which zeal is very apt to defeat its own ends. Like most of those who came into direct communication with Fénelon, de Chanterac loved him with a warm, hearty affection, genuine and bold enough to speak out fearlessly when he differed from, or even blamed, the friend whom he served so devotedly. De Chanterac was a remarkable contrast to the two men who enacted the part of special pleaders for Bossuet at Rome,-his nephew Jacques Bossuet and the Abbé Phelippeaux, - the latter being an acute, attorney-like theologian, whose better information was expected to supply the Abbé Bossuet's deficiencies in theology. Some account of the manner in which these persons carried on the war has been already given in Bossuet's Life, and numerous extracts from their correspondence, ${ }^{x}$ Bossuet and his Contemporaries, p. 423. 
which do not give a pleasant impression, so that we may perhaps be excused from repeating the nauseous details, dwelling here rather on the more dignified, and certainly more Christian-like correspondence between the Archbishop of Cambrai and his friends. One of these was Cardinal de Bouillon, French Ambassador at Rome, who has been calumniated recklessly by Jacques Bossuet and Phelippeaux. That he cordially respected and loved Fénelon is unquestionable; but there seems no ground for imputing to him any of the underhand, dishonest proceedings of which they accused him, and in which they them. selves certainly indulged.

De Bouillon-Cardinal though he was-was also a man of the world, and he thought that Fénelon had thrown away good worldly prospects. $\mathrm{He}$ was not particularly keen about the Quietist dispute, and looked upon the whole thing as more a Court intrigue than a religious difficulty. From the first he told Fénelon that his book was sure to be condemned at Rome: he was a diplomatist, and he foresaw that when a King like Louis XIV. was induced to bring to bear his weight upon a Pope like Innocent XII., the secular prince was certain to be victorious. Fénelon desired de Chanterac to benefit by the Cardinal's advice and countenance; but he refused to correspond himself with him, or to do anything 
which might either compromise him or have a semblance of seeking to use any mere party influence. The Abbé Bossuet announced his intention of setting spies to work directly that de Chanterac should arrive, ${ }^{\mathbf{x}}$ and he kept his word. Moreover, postal communications were so tampered with, that the Archbishop and his representative had great difficulty in communicating confidentially, and letters had to be sent by private hands, or by way of Brussels. Fénelon's instructions to de Chanterac are simple and straightforward like himself. Never once through that mass of letters do we come upon a mean or ungenerous suggestion or unjust accusation of others ; there is not one letter that one feels inclined to wish had never been kept for the sake of the writer. But Fénelon speaks out plainly, and says what he means consistently throughout. "My appeal to the Holy See has vexed our frondeurs very much," he writes Sept. 3, 1697. "Moreover, I have said what greatly displeases them, namely, that I hold myself pledged to submission pour le fait comme pour le droit. You know my principles in that matter. The Church must be aided by the Holy Spirit in admitting or

x Bossuer, Euvres, Lettres, vol. xxix. p. 147. A gentlemanM. Paul Masson by name, who had been to call on de Chanterac-writes, "I was watched as I went in and out-no need to say by whose orders."-Correspondence, vol. viii. p. 49. 
rejecting expressions calculated to uphold or damage the deposit of faith, otherwise she would have no doctrinal judgment; for the sense can only be preserved by expressions, and the tradition of that sense is maintained by such expressions. A man who holds this, and maintains it openly against all the maxims of those. who seek to condemn his book, is not by way of attempting to make a stir in the Church, and to elude the censures of the Holy See." After going at length into the question of his appeal, Fénelon concludes by saying:- " Take care of your health, and defend prayer in a spirit of prayer, and pure love with a disinterested heart. Seek God only in defending His cause. 'I lift up mine eyes unto the hills, whence cometh my help.' I say with Mordecai, 'Thou knowest all things; and Thou knowest, Lord, that it was neither in contempt nor pride, nor for any desire of glory.' If God be satisfied, we ought to be, whatever humiliations He may lay upon us." 2

There are some interesting letters of the same date written from Rome to Monseigneur de Vintimille, Bishop of Marseilles, by a Dominican, Père Serry, giving an outsider's account of the actual position of

× Esther xiii. 12. These latter chapters of the Book of Esther are to be found in the Vulgate and in our Apocrypha. Mordecai's beautiful prayer is singularly appropriate to Fénelon.

${ }^{2}$ Correspondence, vol. viii. p. $3^{8}$. 
things. He says that Fénelon had been advised by the friendly Cardinals and others to make peace at home, and not let the question be pressed at Rome, advice which he did not take, as we know. Even then the authorities tried to escape noticing the book, "fearing that the judgment pronounced upon it would not be altogether acceptable to the King." But Fénelon was thoroughly in earnest in his appeal, as he hinıself said in a private letter of Sept. 25,1697 , to de Chanterac- "If I am proved to have erred in the faith, or to have countenanced error, I will make public reparation in the streets of Rome. I will put myself en pénitence, and, if the Pope pleases, I will resign the Archbishopric of Cambrai."

De Chanterac gives an amusing account to de Langeron of his first interview with the Pope :-

$$
\text { "RoMe, Oct. I, } 1697 .
$$

"Did I not tell you before I came here that I was but sorry at a harangue! I am not up to all these quotations from S. Cyprian. I had not prepared a quamquam. I only had two or three stories in my head, which I told simply, and with a freedom at which I was myself astonished. I was heard most attentively, and what I said seemed to carry effect and persuasion. Once or twice I was interrupted by a question as to what authority the persons of whom 
I was speaking had to treat M. de Cambrai thus? I was assured that his deference to the Holy See gave great edification, and I was desired to tell him that his book should be examined most carefully, and with much graziosità. After all that, what can you say against my harangue? I certainly don't talk Latin well, and I should have been much more afraid of you, if you had heard me, than I was of the Holy Father! He had been told that I was not well, and on my kneeling he raised me at once, asked if I could stand, and when I said that I could perfectly, he still signed to me to lean on his table. It was all his kindness which made me bold. Another time I will tell you two or three little bits of Italian which will amuse you, especially if I could convey the tone of voice, the action of the hand, and the whole manner with which they were said." $x$

No pains were spared to give the impression at Rome-certainly a true one-that Fénelon was out of favour at Court. The Abbé Bossuet distributed copies of the King's letter to the Pope everywhere, talking of his uncle's influence at the French Court as if that ought to decide the votes of the examiners. Fénelon's "Letters to a Friend" promoted his cause considerably, and one of the Sacred College said to de Chanterac_-"There are two things for which I

${ }^{x}$ Correspondence, vol. viii. p. 57. 
would shed the last drop of my blood-truth and charity. I am bound to defend the first against M. de. Cambrai's book, if it militates against it; but if truth is to be found in his intentions, and his expressions can be explained after a kindly fashion, then charity bids me shed my blood in defence of so great an Archbishop." De Chanterac says he went on, as if talking to himself :- "No, it is impossible that God should suffer the goodness and innocence of so great a man to be oppressed. All this will turn to his glory, and at any rate he will have edified the Church by his submission." The Grand Vicaire continues to tell Fénelon that he meets with general kindness and sympathy, especially from the Pope. Cardinal Noris went into all the details of Mme. Guyon's history, etc., with him, and characterised the three opposing prelates somewhat epigrammatically"One, pre timiditate, ex nimia timiditate; the next, acer, vehemens, confidit sibi ipse; the third, favor, gratic."

These three published their "Declaration" against the Maximes; and, October 28th, Fénelon sent a copy of a "Pastoral Letter" to Rome, which, as he says, was written before he saw their document, and consequently was not a direct answer to it. Such an answer he sent later, begging that it might not be printed, for the sake of those prelates, on whom he × Correspondence, vol. viii. p. 86. 
felt that it cast shame. Eventually, however, his friends prevailed, and the document was published, as well as a Latin translation of the Maximes and of the "Pastoral Instruction."

"The main point," Fénelon wrote to de Chanterac, November 12, 1697, "is to preserve our own patience, simplicity, and honesty, and to speak out accurately and unreservedly on each article." $x$

It is hardly possible to go through the lengthy correspondence which is in our hands, whether that of Bossuet or Fénelon's friends, and not feel that, if so much of Court intrigue had not been mixed up in the question, the decision would not have been against Fénelon. Many persons in authority liked the book, and could see no evil in it. One Cardinal said that he thought it so beautiful and so good that he had bought it for his own use, and a Bishop, his director, approved the course ${ }^{2}$ others discussed it favourably. Even in Paris a doctor of Sorbonne wrote that Fénelon's "Pastoral Letter" had quieted people, and that after such a clear exposition of his mind, no one could accuse him of being unorthodox; and that, though the King was urging his Holiness to come to a decision, it was not believed that the Pope could or would condemn him. ${ }^{3}$ A flood of

x Correspondence, vol. viii. p. 166.

${ }^{2}$ Ibid.

3 Ibid. p. 214, Dec. 4, 1697. 
writings against him was pouring forth from Paris $;^{x}$ but de Chanterac had some difficulty in persuading Fénelon to defend himself, so little did he share in the irritated, self-seeking spirit of his opponents. "I beseech you, Monseigneur," de Chanterac writes, December 7,1697 , " neglect nothing that you can do in defence of the truth. Believe me, it is no longer yourself personally whom you defend, and Christian humility should not lead you to give up the cause of religion and the pure Love of God which is attacked." $\mathrm{He}$ yielded, but always with the same mind. "Success is in God's Hands, not ours; whatever happens will be His ordering, and therefore, by His Grace, I shall be content." 3

We need scarcely repeat the details of this ecclesiastical lawsuit, which are given already in Bossuet's Life. The year 1698 found Jacques Bossuet intriguing, the King pressing on for speedy condemnation, the Pope struggling to defend himself from the un-

x Bossuet had published his Summa Doctrina, De Nova Quastione, Declaratio, Aug. 6, 1697, and Quastiuncula, and these were followed by sundry more (see Life of Bossuet). A great person at Rome said, "Meldensis episcopus est Papa Gallus; sed vult confirmare suas decisiones brachio sæculari, brachio regio," adding, that the French Pope, who would not allow Rome to be infallible, nevertheless gave utterance as authoritatively as though he thought himself so, and expected everybody else to think the like!
${ }^{2}$ Correspondence, vol, viii. p. 223.
3 Ibid. p. 250. 
dignified pressure laid upon him by the French monarch, who, under Bossuet's dictation, addressed the Holy Father as though having the right to speak with the authority of a practised theologian, who had clear and well-formed opinions of his own upon all these subjects! Hints were given that the Archbishop of Cambrai could never hope to appease the King and return to Court save by retractation. But he quietly replied that he had no thought ni de près, ni de loin of returning to Court-certainly never at the expense of truth and conscience. Perhaps he might have felt some attraction there on the occasion of his favourite pupil's marriage, ${ }^{x}$ which took place that autumn, and from which he was pointedly excluded. Yet even when others expressed their indignation at seeing the Archbishop slighted and ignored, he could write calmly of it:-

\section{" $\mathrm{Feb} .4, \mathrm{I} 698$.}

"I cannot tell you, my dear Abbé, what the King may have thought concerning me with respect to the Duc de Bourgogne's wedding. One thing is certain, that he did not think fit that I should take part in it, as he did not summon me. Indeed, it would not have been decent for him to have done so, while he permits the three prelates to denounce me to the

I Saint Simon gives a curious account of this child-wedding and its ceremonies, Mémoires, vol. iii. 
whole Church as a Quietist. Another thing which is altogether false is, that I asked, or made any one else ask, the King to allow me to assist at the marriage. You may say as authoritatively as you please that there is no foundation whatever for such a report. But I do not think we should make much use of such weapons as these, which are too human to help our cause. ' $\mathrm{Hi}$ in curribus et hi in equis; nos autem in Nomine Domini." " s

De Noailles' "Pastoral Instruction" against Fénelon led him to give some further answers-for here too Bossuet had meddled, and induced the Archbishop of Paris to erase some kindly expressions towards his old friend; and at every conjuncture the Abbé Bossuet was at hand, to detract and calumniate, to decry and insinuate where open defamation was impossible. He is his own historian, and does not scruple, in his letters to his uncle, the Bishop of Meaux, triumphantly to narrate his spiteful sayings, of which a man one degree worthier would at least have had the grace to be ashamed, if he could not restrain them. He continued to incite his uncle to violent measures, and especially that he should obtain Fénelon's final dismissal from his Preceptorship-a nominal office indeed, as it had now become. "What

${ }^{x}$ Correspondence, vol. viii. p. 383 . 
can the King be waiting for?" he wrote angrily to Bossuet; "why does he not deprive M. de Cambrai of the Preceptorship? You cannot be too speedy in what measures you have to take against him." And he did his best to propagate all manner of slanderous reports concerning Fénelon, urging that any scandalous gossip which might be invented about Mme. Guyon, Père la Combe, or any one connected with the Archbishop, was "of the greatest consequence."

His enemies' machinations succeeded at last, and on June 2, I698, Louis XIV. dismissed every one connected with Fénelon save the Abbé Fleury, who, though a devoted friend of the Archbishop, had never taken any part whatever in the exciting topics of the day. Bossuet boasted that he had saved him from the general wreck. "Fleury has only been retained because I answered for him," he wrote to his nephew, June 3oth. But the Abbé de Langeron and de Beaumont, Dupuy and Leschelle (all men who had been employed about the Duc de Bourgogne for nine years,-not blamelessly alone, but how successfully his altered character and advanced education might show) were rudely dismissed, without any acknowledgment whatever of their valuable services-without, not to say any reward, but even a civil word! None of them were rich men, and the Abbé de Beaumont had 
literally nothing save his salary as sous-précepteur. The malignant Jacques Bossuet received these tidings exultirgly, writing to his uncle that it was the bestand most efficacious news possible, only to be surpassed by that brought by the next courier (which, however, was false ${ }^{2}$ ), that the King had deprived Fénelon himself of his office and its salary; and going on to urge that Père Le Valois, the Duke's confessor, should be got rid of, as worse even than the other four, with spiteful remarks about Père de la Chaise, etc. He went about everywhere parading these events, indiscreetly embellishing them with his own opinions and wishes, and assuring people that all this was but the beginning of the measures the King was about to take for the utter destruction of Fénelon. There is no doubt that Mme. de Maintenon had been worked up into a great

I De Chanterac, on hearing of his dismissal, wrote earnestly to request Fénelon to give his own canonry to de Beaumont. "Il mériteroit assurément mieux que moi de posséder ces bénéfices. $\mathrm{O}$ que de bon cœur je l'en rendrois le maître, si vous le jugiez à propos! et je vous supplie de vouloir y penser devant notre Seigneur. J'espère toujours qu'il vous protégera jusqu'à la fin, lui qui est la véritê et la vie. Il n'y a que lui seul qui vous puisse soutenir au milieu de tant de combats et de si rudes épreuves. Que j'ai de consolation de pouvoir prendre quelque part à vos peines, et de m'attacher toujours plus fortement à vous pour le temps et pour l'éternité! car il me semble que c'est ainsi qu'on doit être uni devant Dieu."-Correspondence, vol. ix. p. 203.

2 Fénelon was not himself formally dismissed until January 1, 1639. 
state of excitement in this matter, and that she promoted the dismissals which reflect so little credit upon her idol the King. Her letters to the Cardinal Archbishop prove this; and one of the sacred conclave, who knew his Paris world pretty well, remarked upon it, "Non est ira super iram mulieris." s

Fénelon wrote to de Chanterac:-

$$
\text { "CAMBrai, Fune 6, } 1698 .
$$

"You will have heard, my dear Abbé, that MM. de Paris and Meaux have had de Langeron and de Beaumont sent away from the Princes. They have carried this measure for two reasons-first, to let it be seen at Rome how strong a part the King takes against me, hoping to influence that Court, the tendency of which seemed too favourable to me; and secondly, to deprive me of any hope of returning to Versailles, even if I should not be condemned at Rome, so as, if possible, to force me to come to some unworthy terms with a view to a return thither. As to the Court, I should be very sorry ever to purchase my restoration by any doubtful expedient." ${ }^{2}$

The Duc de Beauvilliers anticipated his own dismissal, as he wrote to Tronson, June ro, 1698.

Fénelon's enemies had overshot their mark, and

¿ Correspondence, vol. ix. p. 198.

${ }^{2}$ Ibid. p. 147. 
the prevailing impression in Rome was that he had been shamefully ill-treated, with an inevitable reaction in his favour. Cardinal Spada asked incredulously whether such a report could be true, and seemed ashamed for France upon its confirmation; and the Pope, who gave de Chanterac an immediate private audience, was moved and distressed at the harsh act, as a personal friend might be, expressing his warm sympathy.

"I told him," de Chanterac wrote to the Abbé de Langeron, " that M. de Cambrai had expressly told me that he was prepared to resign his archbishopric, and subject himself to public penance and a solitary life for the rest of his career, if there were the slightest ground for accusing either his faith or morals. The Pope was prepared for this, - he had already heard it from a confidential friend; and as I began to speak, he held up both his hands, as a man does when unwilling to hear something, so entirely is he convinced that M. de Cambrai is beyond all possible suspicion." The Holy Father returned again and again with amazement to the ungenerous treatment inflicted. "Expulerunt nepotem, expulerunt consanguineum, expulerunt amicos!" he exclaimed, as though scarcely able to credit it. ${ }^{x}$

De Chanterac's letters, both to Fénelon and other 'Correspondence, vol. ix. p. 217 . 
friends, continue to represent their disgrace as the general subject of conversation, the agents of Bossuet's and de Noailles' party making use of it in every possible way to damage the Archbishop of Cambrai, and to intimidate those who were disposed to take his side. Fénelon's own letters continue to maintain their usual calm, temperate tone, and as one adverse circumstance after another lowers upon him, and seemsin the judgment of an Abbé Bossuet and his like-to crush and humiliate him, he rises up before the truer judgment of a less prejudiced period greater, nobler, more faithful in following his Master's Footsteps than ever.

Meanwhile the examiners were holding their constant sittings upon the Maximes. Between October 12, 1697, and September 25, 1698, sixty-four meetings had been held, and it was known generally that some of the examiners were altogether impressed in Fénelon's favour. Bossuet put forth all his strength in one more book, the Rélation sur le Quietisme, which he formally presented to the King and Mme. de Maintenon at Marly, where the Court was. Mme. de Maintenon wrote to the Archbishop of Paris that the book was making an immense stir-nothing else was talked of ; it was lively and amusing, and every one was wild to read it. She adds that it had made the King very angry, and that he had reproached her sorely for 
having misled him into making such an Archbishop as Fénelon! ${ }^{\mathrm{x}} \quad$ This fresh stroke filled Fénelon's friends at Rome with dismay, coming as it did immediately after the disgrace of all his friends. The Rélation was so skilfully written; it implied so much more than it said; it gave the public to understand that so much of damaging fact was withheld out of generous consideration; such mysterious hints of evil too dark to be expressed abounded,-and the way in which the King and Mme. de Maintenon were known to accept and endorse all this of course confirmed it,-that for a moment men's hearts failed them, and waverers began to say, who indeed could be trusted if such a man as Fénelon were to fail! The Archbishop himself was the only person who seemed to remain calm and unanxious. His letters are quiet and simple, even playful. He had prepared a reply to de Noailles for the press, and on June $\mathrm{I} 3$ th wrote to de Chanterac to say that he had determined not to publish it, as, in the exasperated state into which the King had been

I Lettres, vol. iv. p. 135 .

Dangeau says in his Journal :-_"M. de Meaux présenta au Roi un livre, dans lequel il explique la conduite qu'il a eu avec $M$. de Cambrai, et où il fait le détail des opinions de Mme. Guyon. Ce livre est une sorte de condamnation de tout le procédé de l'Archevêqua de Cambrai dans cette affaire. M. de Meaux donna l'après-dînée ce livre à beaucoup de courtisans. Le Roi en parla à sa promenade, et dit qu'il n'y avoit pas un mot dans ce livre qui ne fût vrai." 
brought, such a step might ruin all his friends still further than was already done. "They hold but by a thread ;" ' and indeed de Beauvilliers' letters to Tronson show that it was true of himself and the Duc de Chevreuse. $^{2}$ June 27 th, Fénelon writes again :- "It distresses me not to be able to publish my Answer to M. de Paris for fear of ruining my precious friends; but one must die to all things, even to the consolation of justifying one's innocence in respect of the faith. I wait God's time patiently." ${ }^{3}$ And now the Archbishop hesitated about answering Bossuet publicly, probably for the same reason. The first mention of the Rélation by de Chanterac is in a letter of June 28 , 1698. Fénelon apparently did not see it till the beginning of July. ${ }^{4} \mathrm{He}$ made sundry marginal notes, and sent it to de Chanterac, saying that any one who would read attentively what he had written on the first eighty pages would be satisfied that his opponent's fabric could not stand. He continued to urge his desire to come himself to Rome, but this was a measure that would have proved so fatal to their intentions that it was never permitted to be entertained as a

I Correspondence, vol. ix. p. 165 .

2 D'Aguesseau says that de Beauvilliers' fate was entirely in de Noailles' hands, and attributes it to the Cardinal's being " more Christian than politic" that he did not overthrow him.-Euvres, vol. xv. p. 350 .

3 Correspandence, vol. ix. p. 208.44 Ibid. p. 249. 
possibility. Meanwhile Fénelon could not but comment on the fact, that in spite of all the King's promises to remain neuter, and to await the Pope's decision, he had been forced into every most extreme measure against one whom it was feared might not be crushed without such partisanship.

On July igth we find de Chanterac writing to urge Fénelon to answer the Rélation publicly, and not to content himself with a private circulation of these marginal notes, and pressing on him the injurious impressions such assertions as Bossuet's are making on the world, maintained as they were by the insinuations his partisans did not scruple to throw out of the revelations they could make but for their desire to screen Fénelon's reputation to the last. Nothing can exceed the urgency with which de Chanterac, more worldly wise, though not less upright in intention, than his principal, presses that the time has come when no considerations, even for the dearest friends, must hinder him from speaking out boldly in his own defence, and clearing himself entirely from these cruel imputations. He writes no less forcibly on the matter to Langeron, in order that he may also urge the point. "I thoroughly enter into your difficulty, and feel for your distress and doubts. I know how far friendship and generosity influence such a heart as yours;-that you would willingly sacrifice life and reputation for 
your friends. And if it were but a private matter that is in question, perhaps it might be better to put up with the injustice of these accusations than to damage them. But I question whether an Archbishop, who for the Church's honour ought to be irreproachable in his ministry, can withhold from replying, when he is accused either as concerns the sincerity of his faith or of maxims which subvert all morals under a garb of piety." The Pope had heard the Secretary, with kindness and sympathy, protesting that there was no occasion for Fénelon to come to Rome in order to clear himself. De Chanterac concludes by saying :"Amid all our fears, and the heavy clouds under which we have proceeded of late, we strive to be firm and endure the storm. We are told on all sides that our cause is desperate, and I say confidently to our Lord, 'Domine, salva nos, perimus,' and hope. Good men may be overwhelmed, the truth never! True doctrine will be uphe!d, and so long as that is the case you will not fall. The more your danger the more I long to help you, and the keener my zeal and affection become. At all events, I would share in your trouble-Come, and let us die with Him."

Fénelon replies that it is easier for him to justify himself than to publish his justification, hindered as he was on all sides by restrictions which would not

1 Correspondence, vol. ix. p. 268. 
allow of his printing it in Paris, while he would be loudly condemned for doing so without the country. $\mathrm{He}$ intreats de Chanterac to be patient more and more as the burden grows heavier, and indeed comforts his friend, and intreats him to take care of his health amid so much pressure and harass, more as if he were the person chiefly aggrieved than the writer !s

August 2nd, Fénelon announces that he has finished his reply to the Rélation. The work had been tedious, he says, for he had no assistants, and was obliged himself to seek out his references and copy everything. By August 3 oth the packet reached Rome, and no one could but be struck with the lucid and admirable style in which, under all his difficulties, this Answer to his opponents was written. ${ }^{2}$

As an answer it seems conclusive; and no fairminded man could read it without regretting that

${ }^{2}$ Correspondence, vol. ix. p. 284 .

2 The Archbishop of Paris, Bishop of Chartres, and Bossuet had all put forth weighty writings against Fénelon within a few weeks. "Il y eut telle province en France et telle contrée en Europe," says Cardinal de Bausset, "où la Réponse à la Relation, parvint en même temps que la Rélation elle-même. On ne savoit ce qu'on devoit le plus admirer dans cette Réponse-la clarté dans l'exposition des faits, l'ordre et l'exactitude rétablis dans leur marche naturelle; chaque accusation détruite par des preuves irrésistibles; le mérite si rare de mettre dans la justification plus de précision que n'en offroient les accusations; l'accord encore plus rare de la simplicité, de l'élégance et de la noblesse du style," etc. etc. - Histoire de Fénelon, vol. ii. p. I 7 . 
Bossuet should have allowed passion to blind him so far as to bring accusations against the Archbishop in the reckless way he did. It is impossible to write a life of Fénelon without quoting the concluding paragraph of his noble Answer, although it has been already quoted in the Life of Bossuet:-

"If M. de Meaux has any further document or witness to bring forth against me, I intreat him to make no half secret of it,-more damaging than an open assertion: I conjure him to send everything to Rome. Thank God, I have no fear of anything that can be openly told and judicially examined; I can only be made uneasy by vague rumours and uninvestigated allegations. If he holds me to be so impious and hypocritical that there is no safety for the Church or himself but in defaming me, he should surely bring forward whatever proofs he possesses, not in libels, but in open judicial proceedings. For myself, I cannot but call to witness Him Whose Eyes penetrate the thickest darkness, and before Whom we must all soon appear-He Who reads my heart, and knows that I cleave to no person and no book, that I am bound solely to Him and His Church, that I mourn before His Presence with many a cry that $\mathrm{He}$ would restore peace, and put an end to this day of scandal; I ask Him to restore His shepherds to their flocks, to gather them together in His Fold, and to 
grant to M. de Meaux as many blessings as he has heaped crosses upon me."

The reaction on Fénelon's side produced by this work was tremendous. He sent it himself to Innocent XII. on August 13 th, with a long Latin letter. He was obliged to send a special courier, in order to make sure that the various copies sent to Rome-for de Chanterac, etc.-should reach their end untampered with. The Papal Nuncio, who of course received it earlier in Paris, writing to acknowledge the book, mentions Bossuet's three tracts, De Nova Quastione, just out, adding that he "could not help telling $M$. de Meaux that this was not the way to put an end to the strife! I have intreated that no more be written: would to God there had been nothing written on the subject!"

In Rome the excitement caused by the book was great : it was the universal topic, and every one seems to have been impressed by its power and complete success in clearing Fénelon from all Bossuet's accusations. No one felt this more than the Abbé Bossuet, who, in his dismay, beset the Pope with intreaties to delay the judgment expected on the Maximes until

I "Fra tanto non ho potuto contenarmi di non dire a questo prelato che questa non è la forma di finire. Io ho pregatò che più non scriva; e volesse Dio che non si fosse da esse mai scritto in questi materie : pagherei del mio sangue !"-Correspondence, vol. ix. p. 376 . 
his uncle should have had time to answer the book. His Holiness remarked that such a request was very inconsistent with the urgency with which Bossuet himself was pressing for the judgment, ${ }^{\mathbf{x}}$ and seems to have sent the pettifogging Abbé away in no very smooth state of mind! De Chanterac had a very comforting interview, in which, as ever, the Holy Father expressed himself most warmly with regard to Fénelon, and, as the Secretary remarks, "nothing could be better than the Holy Father's inclinations, if one could only be certain of their stedfastness; but his great age and lack of memory are so patent that one cannot rely overmuch on what he says." ${ }^{2}$ The faithful Secretary was greatly cheered by seeing how every one, official and unofficial, acknowledged that Fénelon was fully cleared. One of the most learned Bishops in Rome told him that " nothing more could possibly be desired for de Cambrai's justification, and that he had smashed M. de Meaux." 3

Theologians, doctors, prelates, religious, all joined in the universal applause. "No apology ever met with such general approbation," de Chanterac (whose recent letters had been very downcast) writes to de Langeron. He urged that the Latin translation might be sent speedily, as many could not read it at all, or

- Correspondence, vol. ix. p. 399.

2 Ibid. p. 405 .

\footnotetext{
3 Ibid. p. 393.
} 
but imperfectly, in French. The Pope had it almost immediately translated into Italian for his own benefit. Many of the Cardinais told de Chanterac, sans façon, that they were thoroughly satisfied, and commented sharply on the lack of charity in the action taken against him. One prelate (famous for his learning, and possessing the confidence and esteem of many Cardinals, says de Chanterac) observed that the Réponse had worked a great change in men's minds, and had set the matter upon the right road. Fénelon received all the hopeful tidings calmly, as usual, remarking (September 6, 1698) that they must expect further difficulties; and indeed they seemed close at hand, for Bossuet was already writing again in reply. "If Rome allows us to go on thus, we shall never come to an end," he says, "and the scandal will wax ever greater. I do not wish to silence M. de Meaux if he has any testimony to bring forth against me, but I do think he ought to have a fixed limit assigned within which to say all he can say, and after that I ought to be heard, so that, upon my final reply, the Pope should decide without any further discussion. . . . If the Pope desires me to give up my book, I shall do so without hesitation, at his first sign; but after all the scandal roused, it would be like a tacit avowal of what I am accused of if I abandoned it otherwise." 
The good Abbé de Chanterac was greatly cheered: his was no ordinary strain of body and mind, and Fénelon's letters are full of affectionate consideration for him and gratitude for his devotion.

"Do not fear now," the Abbé writes, September 18, 1698, "that I shall be worn out with our troubles or overmuch depressed. When I saw you in your innocence on the point of being overwhelmed for want of duly answering all these unjust accusations, and your silence misinterpreted, and causing truth to be confounded with error, I must confess that I was sometimes terribly out of heart, and as I sat under my juniper-tree I was not always master of my anxiety. But now that the truth is recognised, and that you have done all in your power to clear and defend it, I shall accept whatever can come as the ordering of God's special Providence for us, and shall neither murmur nor be cast down, but submit calmly to His good pleasure." ${ }^{x}$

At this juncture de Noailles and the Bishop of Chartres seemed to feel that they had gone too far under Bossuet's furious driving, and some feelers were put out through a safe person, intimating that Mme. de Maintenon and her Director greatly desired peace and reunion, but that they met with every possible hindrance. Fénelon was ready to meet any ${ }^{x}$ Correspondence, vol. ix. p. 460. 
overtures in his usual kindly, straightforward spirit,apparently without the approval of his friends, -but he knew the Cardinal Archbishop too well to suppose that either he or the Bishop of Chartres had strength or courage to resist Bossuet's vehemence. And he was right: nothing came of the attempt at reconciliation, and Bossuet did his best to widen the breach by bringing out some remarks upon Fénelon's Réponse. It was even more violent, but less weighty, than his previous writings, and was met by Fénelon in an immediate reply, which he says took three days to prepare, six to write out, and four or five to print ${ }^{x}$ - a reply which confirmed all honest men's judgment in his favour. How great his difficulties were, and how bitter and dishonest the cabal against him, may be judged by the fact, that his books were stopped when sent by post or public conveyance, and that his only way of insuring any justificatory documents reaching Rome in safety was to send them by special courier!

The calm dignity of this counter-reply is wonderful, and carried a prodigious moral weight with it. Cardinal de Bouillon did not hesitate to pronounce it the most masterly effort of the human intellect he had ever seen! Fénelon wrote to de Chanterac with it, Nov. 7, r698, "I hope you will be satisfied with

\section{Correspondence, vol. ix. 1. 543.}


my answer. If it seems rather stronger in tone than what I have written before, it is because I cannot refrain from expressing my horror at such accusations, and some readers might suppose that my moderation arose from fear. Anyhow, a comparison will show that my expressions are very mild and patient compared with those of my opponent. . . . In Paris my reply is considered scarcely necessary, and the King is impatient of my writings. M. Clement, who is in M. de Chartres' confidence, keeps on writing to me about a reconciliation, and evidently the Bishop and Mme. de Maintenon wish it. $\mathrm{He}$ talks of direct overtures to be made shortly; but, without refusing any, I shall reply that, being in the Pope's hands for judgment, I cannot with propriety do anything save in obedience to him.... My health keeps good, thank God, amid work which would overwhelm a stronger man. . . . God be with you. I desire nought save His Will in whatever may befall me, however hard to bear."

The Abbé Bossuet was furious. He wrote to his uncle that Fénelon's party was greatly delighted with this last book, and urged the Bishop of Meaux to use every means to crush Fénelon, and leave him no means of escape-to hunt him down like a wild beast!

' Correspondence, vol. x. p. 8. 
Again and again he exclaims- "If you do not make haste, it will all be useless !"

But Bossuet did not attempt again to write anything of importance, and he ceased to urge his personal accusations with respect to Mme. Guyon. Probably he felt himself what d'Aguesseau emphatically says, that Fénelon had won the confidence of the public rather than himself. ${ }^{x}$ The Archbishop had some controversial correspondence with the Bishop of Chartres, but the war of writings was practically over, and the victory certainly remained with Fénelon.

Meanwhile the long-protracted examination of the Maximes had come to an end on September 25, 1698, after sixty-four sittings, at many of which the Pope himself had assisted. "They gave their votes in writing, and were divided to the end," de Chanterac wrote." "If we may believe an Archbishop, a Bishop, a General of Carmes déchaussés, one of the Pope's old theologians, and a Procureur-général of a reformed order of S. Bernard, our doctrine is that of the Church, and our book good as a whole, or if taken by individual propositions. If, on the contrary, we are to believe certain Religious of no very special weight, long distinguished by their violent opposition

'Mémoires sur les Affaires de l'Eglise de France, Euvres, vol. viii. p. 205 .

$=$ Correspondence, vol. ix. p. 48I. 
to everything savouring of the Jesuits, the book, though orthodox in doctrine, is sometimes inaccurate in expression, and therefore deserves censure. If these examiners were judges, we should be dismissed on every point of accusation raised against us-I mean against our book; for it is an unheard-of thing that the Holy Office ever condemned any person or book where the votes were equal for and against;but these examiners have only a consulting voice, and the Cardinals or the Pope judge and decide." $x$

Innocent XII. would gladly have acted upon the examiners' opinion and have finished the matter; but after all the pressure put upon him by the Court of France, under Bossuet's influence, he could not follow his own conscience and will, and he accordingly referred the case to the College of Cardinals. This book then, pronounced by the Bishop of Meaux to be "subversive of all religion," was to undergo another inquisition before its fate could be sealed.

The number of interesting letters of this period is embarrassing from its richness-one scarce knows what to quote and what to withhold, but at all events we may be allowed to give the following letter, written by Fénelon, after his long silence, with such quiet and respectful dignity, to Mme. de Maintenon. It is dated December 1698 :-

\footnotetext{
${ }^{x}$ Correspondence, vol. ix. p. 482.
} 
"So long as it was impossible for me to keep silence in public, I felt it right to be silent to you; but now, when my case must be already decided at Rome, and when I expect hourly to receive that decision, I feel no longer obliged to practise such reserve, but that I may presume to inform you concerning my own affairs, with some remains of confidence in your former kindness. In a letter which I have just had the honour to write to the King, I have set before him the conscientious reasons which constrained me to defend my book against my brethren, and to wait the judgment of my Superior. It is useless to weary you with a repetition of all this, Madame, as you will read it in my letter to his Majesty. All that I would ask you to allow me to say is, that this book, which was pronounced so incapable of any catholic interpretation, and by reason of the impiety of which my brethren thought fit to drive me to the last extremity,-this book has seemed to the five chief theologians selected by the Pope from out the whole Church of Rome, not only to be capable of the best construction, but still more, so pure and correct, that, according to them, it needs no explanations. It is true that five others are against my book, but the voice of the public has decided that, though highly respectable, they have not the same weight as the first. Moreover, even they allow that in a hundred places the book condemns all the errors they fear, taking 
refuge in the assertion that certain less plain passages might countenance error; as though innumerable clear passages would not altogether outweigh some few less distinct utterances. Moreover, the examiners who are unfriendly to me are by no means in favour of M. de Meaux'criticisms, whichnone of them have attempted to defend or to excuse. . . . In short, after fifteen months' examination, the five principal theologians concerned maintain that my book is uniform with the doctrine of the Saints, and altogether opposed to the delusions of Quietism. The inviolable rule of the Holy Office, the strictest of all tribunals of faith, is that a book is held to be justified unless a majority of votes condemns it. And this rule is conclusive in my favour. This anticipatory judgment clears me, Madame, in the face of all Christendom. Am I required to be a closer theologian and more opposed to Quietism than these five examiners whom the Pope has selected? I was not occupied fifteen months in writing this book, as the examiners have been investigating it. I had not studied, as they have, all the subtle objections which can be brought to bear against it. I wrote simply and trustfully, without foreseeing any of the evil interpretations which have been saddled upon me against my will. I imagined myself to be taking precautions enough, when following with unlimited docility all the counsels of those who were most sensitive to the 
danger of delusion. All Christendom beholds now, Madame, that the Pope's chief theologians uphold my book, and that if an extraordinary course had not suspended the wonted use of the Holy Office, I should have won my cause even according to the strictest rules. It might have seemed natural even to have somewhat relaxed such rules, to avoid damaging a submissive Archbishop of innocent life. But, on the contrary, Rome is required to overstep its own strictest rules, in order to crush that Archbishop as a Quietist. If the Pope sees fit to yield, I have no choice but to sacrifice myself and obey my Superior.

"I only take the liberty, Madame, of telling you all that is being done at Rome when it is probably over, and I lay it before you only to show you what my opinions and conduct are. Whatever it may please God should occur, nothing will be seen in me save docility towards the Pope my Superior; save zeal, submission, and gratitude to the King my master; save respect, attachment, and gratitude to you, Madame; save love for the Church's peace, abhorrence of novelties, and forgetfulness of the severity with which my brethren have attacked me. While thinking of them all in a spirit of true brotherly kindness before God, I cannot but be alive to the differences with which some have treated me from others.

"I have but two things more to say, Madame. 
First, that if the Pope condemns me, I shall endeavour to bear my cross without a murmur, and with a submissive heart; and that if the Pope will but follow the ordinary rules, as I hope, and justify me, I shall stand towards my brethren exactly as if they had never attacked me. And next, that amid all the crosses heaped upon me, there is none heavier than that of having so greatly offended you; yet I cannot complain if you believed three great prelates rather than me, or if you preferred the Church's welfare to my individual reputation. Reflecting on the impressions given you, I can understand that it was natural you should have gone even further, and that only a lingering kindness for me has restrained you. I feel this, and shall ever feel it. I intreat God with all my heart, Madame, that $\mathrm{He}$ would comfort you in proportion to the pain I have unwillingly caused you, and fill you with His abundant Grace to work His Will. While I live I shall be ever your most faithfully attached and respectful servant," etc. etc.

If Mme. de Maintenon answered this letter her reply has been lost, but it seems probable that she did not answer,-in fact, it would have been difficult for her to know what to say; she had been thoroughly impressed $^{x}$ with the danger of a rampant Quietism if

× Lettres, vol. iv. p. I43. "'Si M. de C. n'est pas condamné, c'est un fier protecteur pour le quiétisme."-To de Noailles. 
Fénelon were not condemned, and the King had been induced by Bossuet to make it almost a personal question, so keenly did he press Innocent XII. to condemn the Archbishop and his book.

A suggestion of the Abbé Bossuet's had already been acted on, and a censure passed on twelve propositions taken from the Maximes by sixty doctors of Sorbonne in October 1698 . It is noticeable that this censure was a paper drawn up by Pirot, who had studied the original manuscripts, suggested alterations which were adopted by the author, and finally pronounced the book worth its weight in gold! It would seem as if many of the signatures appended to this document were merely a sort of Court compliment; but the manœuvre was not a success. The censure carried little weight at Rome, where it was intended to make a great impression; while, on the contrary, considerable displeasure was excited at these doctors arrogating to themselves the right to prejudge the sentence impending at Rome, and Cardinal de Noailles had to take some trouble to excuse himself for having allowed such impertinent dogmatising! The next effort made was a bold one. It must have been close upon the time of Fénelon's letter to Mme. de Maintenon that Bossuet made the King write a threatening letter (one can call it nothing else) to the Pope. It was evidently dictated by Bossuet, and 
intended as a coup de main. In spite of a semblance of smooth words, and the signature of his Holiness's "most devoted son Louis," it was dictatorial and impatient to a degree of which the Pope was fully conscious; and a letter went by the same courier to the French Ambassador, Cardinal de Bouillon, making him practically responsible for the immediate completion of the King's wishes. ${ }^{x}$ A few days later the stroke so long aimed at Fénelon was brought about, and, Jan. I, I699, Louis XIV. caused the official list of his grandson's household to be brought to him, and with his own hand crossed out the Archbishop of Cambrai's name, both in title as Preceptor and on the list of salaries. Fénelon never took much notice of this fresh affront; he had felt the dismissal of his friends too much to feel his own very keenly; and it was not likely that a man always so indifferent to money, and who had actually offered his revenues to the Privy Purse when it was greatly straitened some few years earlier, would be very sensitive on the score of salary. Louis XIV. certainly was the greatest loser by the measure. Probably the only person mean enough really to rejoice in the fact was Jacques

z "C'est bien à nous," Cardinal de Bouillon said to his brethren of the Sacred College, "à defendre le pur amour; à nous, qui ne connoissons que l'amour impur!"-DE LA BAU. MELLE, Mémoires, vol. iv. p. 97. 
Bossuet, who congratulated his uncle, only bemoaning that the Duc de Beauvilliers did not share his friend's fate-a very dangerous omission, so he pronounced it to be.

The Pope, beset from without by Louis XIV., and from within by the unremittingly impertinent assaults of the Abbé Bossuet, put on all the speed he could. All other business of the Holy Office was suspended, we are told ; ${ }^{x}$ but even so matters did not advance rapidly, and in spite of the contre-poids terrible of the Court of France, there were men who did not see why they should be browbeaten on their own territory, moral and material, even by the Grand Monarque himself.

De Chanterac, however, foresaw that all this pressure must end in the condemnation of the book. His best friends at Rome said it was not possible for the Pope to resist all the efforts made by the King of France. $^{2}$ Innocent XII. was kind and gracious still

× Correspondence, vol. x. p. 233.

2 “Très-Saint Père,-Dans le temps que j'espérois de l'amitié et du zèle de Votre Sainteté une prompte décision sur le livre de l'Archevêque de Cambrai, je ne puis apprendre sans douleur que ce jugement, si nécessaire à la paix de l'Église, est encore retardé par les artifices de ceux qui croient trouver leur intérêt à le différer. Je vois si clairement les suites fâcheuses de ces délais, que je croirois ne pas soutenir dignement le titre de fils aîné de l'Église, si je ne réiterois les instances pressantes que j'ai faites tant de fois à Votre Sainteté, et si je ne la suppliois 
in their personal interviews, but de Chanterac wrote that he seemed thoroughly wearied and worn out with the subject;-both he and the Cardinals were terribly frightened by the threatening solicitations they received from France. A feeling began to prevail that it would be for the general peace of the Church to give up Fénelon's book, even if there were not much amiss in it. Couriers from France were arriving daily with every stimulus to action that could be brought to bear, and no means were spared to make, not the Pope only, but all the Cardinals, feel how awkward a thing it might prove to them to quarrel with the Court of France-a powerful Court, whose support they were so liable to need any day. ${ }^{x}$ The Pope called for public intercessions that he and his Sacred College might be guided rightly in their judgment, evidently

d'apaiser enfin les troubles que ce livre a excités dans les consciences. On ne peut attendre présentement ce repos que de la décision prononcée par le Père Commun; mais claire, nette, et qui ne puisse recevoir de fausses interprétations; telle enfin qu'il convient qu'elle soit, pour ne laisser aucun doute sur la doctrine, et pour arracher entièrement la racine du mal. Je demande, Très-Saint Père, cette décision à Votre Béatitude, pour le bien de l'Église, pour la tranquillité des fidèles, et pour la propre gloire de Votre Sainteté. Elle sait combien j'y suis sensible, et combien je suis persuadé de sa tendresse paternelle. J'ajouterai à tant de grands motifs qui la doivent déterminer, la considération que je la prie de faire de mes instances et du respect filial avec lequel je suis," etc. etc.--23rd Dec. 1698 .

${ }^{x}$ Correspondence, vol. x. p. 257. 
quailing under the pressure from without; and Mme. de Maintenon wrote (Jan. 20, 1699) that the answers from Rome were unsatisfactorily vague-she feared lest by seeking too much the party pressing for Fénelon's condemnation might lose all- "the Pope will promise nothing, not even diligence." Almost on the same day (Jan. 23rd), Fénelon wrote to de Chanterac:- "All Europe will believe that an innocent Archbishop has been sacrificed to please the Court, though really to its simple damage, and contrary to all its true interests, as well as those of wholesome doctrine. As for me, I can only obey and be silent, having delivered my conscience, when once my Superior speaks; but I do not hesitate to say that a censure or prohibition will hardly damage the Holy See with Europe generally less than it will me. Come what may, I shall remain firm to the end, and wait in simple faith for truth to set me free. And for your part, my dear Abbé, fix your heart firmly on the words, 'Quis es tu, ut timeres ab homine mortali?' If God does not choose to make any further use of me in my ministry, I shall give myself up to loving Him for the rest of my life, being no longer able to work towards making others love Him. I shall feel the value of all you have done for me, as much as if you had obtained the approval of my book; I shall be no less grateful for the unspeakable trouble you 
have gone through for so long. Do not be afraid of men. . . Heaven and earth will pass away, but the words of Jesus Christ will never pass away, and His Truth abideth for ever." $x$

Meanwhile the Cardinals sat in conclave-but by no means harmoniously ${ }^{2}$ - on the much-discussed book. Evidently they felt strongly the dangers which beset them. "It will not do," they prudently said, "to fire great guns at a king. Rome's wisest course demands of her to yield to him whatever may be yielded without wounding the first truths of religion." 3

The recent struggle with the Gallican Church was fresh in all minds, and new collisions were to be avoided. Nevertheless, Innocent XII. in his heart sided with Fénelon, and toiled to deliver him from the snare, much as Jonathan toiled to deliver David from the persecutions of Saul. When at length the Sacred College decided that there were twenty-three reprehensible propositions in the Maximes, only differing as to whether they should be censured specifically or generally, they referred this final decision to the Pope, and he saw that there was no help for it,-

x Correspondence, vol. x. p. 266.

2 As one of the Cardinals said of Fénelon's opponents, "Vinceranno, ma non trionferanno." Another said, "The book may be prohibited in order to satisfy France, but it cannot be condemned."

3 Correspondence, vol. x. p. 303 . 
the book must be censured. The second week in February 1699, he gave de Chanterac an audience, in which he said that the Archbishop's doctrine was noways questioned, every one approved that-the book alone was doubtful, whether it was always worded in strict conformity with the author's real intentions. Shortly after, his Holiness held Congregations on three days running; and on February 24th he appointed Cardinals Noris, Ferrari, and Albani, to draw up the decree embodying the judgment, pointedly excluding Casanata, in spite of his claims through age, position, and theological experience, because he was known to be an ally of the Abbé Bossuet and his cabal. However, Cardinal Albani insisted on the revocation of this exclusion, and the Pope reluctantly yielded, even then taking a measure which the indignant Abbé Bossuet describer as "unheard of in any previous Pope," namely, sending the Assessor and Commissary of the Sacred Office to all the Cardinals, with special injunctions to use all possible personal gentleness and courtesy towards M. de Cambrai, giving them clearly to understand that his own desire was to give him the most lenient handling possible; and further, Pope Innocent sent a special messenger to Cardinal Casanata, whom he knew to be most under French influence, and therefore least favourably disposed towards the Arch- 
bishop, bidding him seriously to reflect, as in God's Sight, on the danger of compromising the Church, and so to consult his conscience, and admit no other influence.

The three Cardinals first appointed had already held three sittings, in which they had decided to issue the decree in the form of a simple brief, rather than a formal bull; also that this brief should distinctly affirm that his Holiness did not intend to condemn the author's explanations of his book (" non intendimus improbare explicationes auctoris"); and further, that one point, which had arisen solely through a mistake (the so-called trouble involontaire of our Lord), should be spoken of as "quam tamen propositionem negat auctor esse suam," while the name both of book and author were carefully omitted. But Casanata, irritated at the Pope's wish to exclude him, proved the justice of his Holiness' desire by pertinaciously insisting on using his power by frustrating all these indulgences-if indeed they were not rather strictly acts of justice-towards Fénelon; and being possessed of an inflexible will and overbearing temper, he positively refused to sign the decree until his colleagues yielded, and by sheer dint of imperious pressure he succeeded. Innocent, wearied out with the whole business, called an extraordinary Congrega-

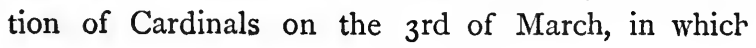


Casanata overpowered the others; and the Congregation accepting the decree, it seemed that at last the long-drawn discussion was about to end, and the amiable Abbé Bossuet wrote off his pious thanksgivings for the triumph of truth to his uncle. His cup was nearly dashed to the ground, however.

The Holy Father was so wounded and shocked at the perpetration of what he knew to be a grievous injustice, and so reluctant to sign the decree which was to condemn a man he heartily admired and reverenced, that a fresh plan was devised to relieve his conscience and feelings. This was that he should, instead of condemning the Maximes, put forth twelve canons now laid before him, asserting the Church's true doctrine as opposed to Molinos and the Quietists-a measure which, as it was asserted, would confirm the true doctrine and justify the Holy See, without casting any blame on the Archbishop of Cambrai. Innocent eagerly grasped at this alternative, and it promised to succeed, but the Abbés Bossuet and Phelippeaux moved heaven and earth to prevent it, openly urging upon all the Cardinals how bitter the wrath of Louis XIV. would be, as well as every other motive they could think of. In due course of time a tremendous fulmination from the Grand Monarque arrived, written obviously to terrify the unfortunate Pope into submission, and clearly 
dictated by Bossuet, while purporting to be the King's own writing. But he might have spared himself this unworthy act. A Congregation had been called on March 8th to discuss the twelve canons, in which Casanata overpowered the other Cardinals, forcibly representing that there was no saying to what extremities the Court of France might not be moved by opposition to its stringent desires, and somewhat ungenerously urging that the Archbishop of Cambrai's submission and piety could be better trusted than that of his three royally-protected opponents. So the project of the twelve canons was given up, greatly to the mortification of the Pontiff, who felt himself helpless in the toils of France. On March $9^{\text {th }}$ the decree was submitted to the Cardinals individually, and on the roth a Congregation was held in which the condemnatory Brief was finally read by them. On Thursday the I 2 th the whole Sacred College was solemnly assembled at the Palace of Monte Cavallo, and there the decree was accepted by the whole body of Cardinals, and signed by the Pope in their presence, being immediately-according to customprinted and posted in all the principal public places of Rome.

Cardinal de Bouillon, as in duty bound, and Jacques Bossuet, in hasty gratification of his spite and hatred, sent off couriers without a moment's delay to the 
King and the three prelates. He was afflicted, and so, we must honestly confess, was Bossuet himself, because the Pope and the majority of Cardinals refused to associate the name of heretic, or even of anything resembling heresy, with Fénelon, and had absolutely rejected the usual appendage to a brief of condemnation-ordering the book condemned to be burnt. But the project of the Twelve Canons had thoroughly alarmed Fénelon's enemies, showing them how readily their hoped-for victory might be turned into defeat; and though not satisfied with the stringency of the measure, Bossuet told his nephew it was better to accept it as it stood than to run the risk of seeing it made even less weighty if tampered with.

"M. de Meaux had gained his suit at Rome against M. de Cambrai," as the Abbé Le-Dieu, Bossuet's private secretary, writes; and it is not the first or last time in which a victory has cost the victor dearly in repute and character.

Let us turn from the dark, malignant, ungenerous side to the brighter one of the noble-hearted man who was defeated. De Chanterac wrote at once to him as follows:-

$$
\text { "Rome, March 14, } 1699 .
$$

"Now indeed, Monseigneur, the time has come for you to practise all that your religion has taught you of 
the most holy and absolute conformity to the Will of God. This indeed is a time which calls upon you and all who love you to be obedient to Christ to the death, even the death of the Cross, so that they who live should not live unto themselves. You will need all your piety, and all the submission which you have repeatedly promised to the Pope, in order to possess your soul in patience while reading the Brief which he has issued against your book. It would be useless to dwell here upon certain circumstances attending this decision, which would only serve to render it more overwhelming. The zeal of some partisans went so far as to imagine themselves serving God by demanding still harsher and more violent utterances, and the Pope felt himself doing great things for you in resisting these. It was thought right that I should see him, not only to assure him of your submission to his judgment, but for other reasons, into which I may be able to enter further on. How different his private utterances were to what his Brief sets forth to the public! All of us put together can hardly be so grieved as he alone seemed concerning what was painful to you in the judgment-he was so altered one would scarcely have known him. He repeated over and over again that he reckoned you a very great Archbishop, very pious, very holy, very learned-they were his own words, piissimo, santissimo, dottissimo, 
for he spoke Italian. I will not repeat to you what I answered.

"All your friends, Monseigneur, feel that you ought to receive this Brief as you promised to do, with perfect submission, simply and sincerely. They are convinced that the more straightforwardly simple it is the wiser it will be at last. It seems as though our Lord purposes that you should thereby edify the whole Church as widely as your enemies have sought to have it believed you scandalised it by your book. This single example will give a clearer impression of the perfection of Christian virtue than all the holiest utterances you could make concerning religion. I have not hesitated to say that you would thoroughly fulfil all your promises in this respect, for I have always been deeply impressed by the touching words I have repeatedly heard you say-that you thought nothing of yourself or your book, and I know how throughout you have studied to mould all your conduct upon the Author and Finisher of the Faith, Who, solely in order to give the greater glory to God, knew how to bear His Cross and despise the shame."

"March 19th.

"Jesus Christ hanging on the Cross, exposed to the mocking judgments of men, and forsaken of His Father, seems to me, Monseigneur, the one Example held before you by religion, and upon which the Holy 
Spirit would mould you. It is, above all, in such a condition as that wherein Providence has placed you, that the just man does indeed 'live by faith,' and when we need to be rooted and built up in the Love of Jesus Christ, from which who can separate us? 'Tribulatio, an angustia? neque mors, neque vita, neque creatura alia.' I never felt so closely drawn to you in love. I cleave to you, and indeed I feel a certain consolation in abiding quietly and firmly at the foot of your cross, in testimony of the confidence I have ever felt in your piety."

Fénelon had already received the bad news when de Chanterac's letters reached him. His brother the Comte de Fénelon heard the tidings first in Paris, and started off instantly for Cambrai, thinking that to receive them through a kindly channel would at least lighten their weight; and he arrived on the Festival of the Annunciation, just as the Archbishop was about to preach in the Cathedral. Fénelon was but human, and it is not possible but that he must have felt the blow; nevertheless, with his usual marvellous sweetness and freedom from self-consciousness, he was not disconcerted, as most men would have been, but merely paused a brief while in order to arrange his thoughts, and then, throwing aside his intended sermon on the special I Correspondence, vol. x. pp. 418-425. 
festival they were keeping, he preached on the duty of absolute submission to authority. The news of his trouble was already whispered about among the congregation, which was riveted by the noble simplicity and calm dignity of the Archbishop, and the eyes of most overflowed with tears of admiration and respect as they listened to his heartfelt words.

His assertions of unqualified submission had been thoroughly real; and now that they were put to the test, their reality was proved. His reply to de Chanterac was as follows :-

"Cambrai, March 27, 1699.

"I had already heard from Paris of the condemnation of my book, my dearest Abbé, when I received your letter. I have not yet seen the Bull, but I know that it is as strong against me as if M. de Meaux himself had penned it. I can only give God praise and be silent, or at least give forth one single utterance, whereby to prove my promised submission to my Superior. I am only waiting for the exact words of the Bull in order to frame my Mandement upon them. If I can obtain it from Paris, I shall not lose a moment in drawing it up, and I shall endeavour to make it as short and as simple as possible. I hope you will send me a printed copy of the Bull by the next courier, together with such advice as you have doubtless 
received concerning the line I should adopt. My own reflections are as follows:-

"I. The customs of France, which it would be held unpardonable in me to violate, forbid me to acknowledge the Bull until it has been accepted by Parliament. Consequently I must necessarily await this formal act before making any act of submission. I beg you will explain to all our friends that this alone delays the Mandement I purpose putting forth.

"II. I propose (subject to advice) to touch only four points in my Mandement:-Ist, That I believe myself to have insufficiently explained my meaning, when the Head of the Church, with his superior light and authority, so judges, and that consequently I condemn my text unreservedly, and with the same qualifications as his. 2nd, That I owe it in justice to myself to declare yet once more before the whole Church, what will in noways contradict the judgment, namely, that I never understood my text, or supposed any one could understand it, save in the sole sense which I have al,vays assigned it in all my justifications. $3 r d$, That, nevertheless, I do not say that the Church need be troubled about the distinction between the author's meaning and the text, inasmuch as my meaning and intention, however pure, does not alter the natural sense of the text such as it is judged to be by the Pope. 4th, That I submit the doctrine of my defence (which is 
my very own) to the Pope, and if it contains error, I intreat him to point it out.

"III. In this, and in my whole action, I desire to show with perfect sincerity that $I$ feel no resentment in my heart, but true respect for the Holy See, and unreserved submission to its judgment, however severe. At the same time, I ought not to take any superfluous steps with respect to Rome, which would be mean after all that has passed. I shall ever continue in submissive unity with her. But I beg that you will quit Rome, and before leaving, that you will do nothing more than what is required by strict courtesy. I will not complain, I submit sincerely and unreservedly; but it would be wrong to act as if one were satisfied when one has no right to be so."

After one or two more similar remarks, Fénelon proceeds to desire de Chanterac to leave Rome, if possible, without seeing Cardinal de Bouillon, saying, " He has been almost as deeply calumniated as myself. See no one to whom you may do harm, while they can do you no good." And the letter concludes with all manner of kindly considerations for de Chanterac's welfare and comfort, as though he were the chief person to be considered. ${ }^{x}$

Two days later the Archbishop wrote to the Duc de × Correspondence, vol. x. p. 440. 
Beauvilliers :- “. . . For my part, I try to bear my cross humbly and patiently. God has graciously granted me to be at peace amid sorrow and bitterness. Amid all these troubles I have a comfort little appreciated by the world, but very substantial to those who seek God heartily; namely, that my course is clear, and I have nothing to hesitate about. I have only to submit and be silent, as I have always wished. All I have to do is to choose the expressions of my submission. I prefer the shortest, simplest, plainest, and most unreserved. My conscience I submit to that of my Superior. In all this, so far from referring it to my opponents, I see no human agent; I see God Only, and I am content to accept what He does.

"Sometimes I can hardly help laughing at the alarm certain worthy people display lest I should not be able to make up my mind to submit. I am occasionally bothered with long exhortations, written to induce me to submit myself, telling me of all the glory to accrue to me through such humiliation, and what a heroic act I shall perform! All this is rather wearisome, and tempts me to say to myself, Whatever have I done to all these people to make them think that I should find such difficulty in preferring the authority of the Holy See to my own poor lights, or the peace of the Church to my book? Still I see that they are quite right in imputing great imperfection to 
me, and supposing me very averse to a humbling act. So then I readily forgive them, and I mean to try and be grateful for their fears and exhortations!

"As to the trial involved in an act of full and absolute submission, I must simply tell you that I do not feel it at all. My Act was drawn up the day after I received the news, but I felt bound to keep it back until I knew the right mode of procedure. Bulls are not recognised in France until they have been passed by Parliament. I know not whether the same form is observed with respect to a Brief containing a doctrinal judgment upon an Archbishop. But while doubtful, I suspend my Mandement; for, whatever may be said, no one is more heartily French than I am. Directly I know the rule, my Act will appear. You will remember, if you please, that I have not yet received the Pope's judgment either from Rome or from the Nuncio; but I shall not lose a moment as soon as I can be sure that I am in no way acting contrary to the customs of France. My only consolation is obedience, and if people had really known my mind on this point, none of their vain fears would have arisen." x

Many other letters to different friends, written at this critical period, hold the same language, which was unquestionably the simple expression of Fénelon's ' mind, and the dignity which blends with his humility

I Correspondence, vol. x. p. 449. 
is intensely characteristic of the man. $\mathrm{He}$ was so desirous to lose no time in expressing his mind publicly, that, fearing the endless delays which might arise with Government, the Archbishop wrote to Barbesieux, the Secretary of State, inclosing a memorial to the King, requesting to be informed what were his Majesty's intentions, and whether he might issue his Mandement without waiting for Parliament formally to register the Brief.

These facts were made generally known through a correspondence with $M$. de Sène, Bishop of Arras, who, as one of Fénelon's suffragans, wrote to him on hearing the news from Rome. Fénelon's reply was at once made public by Mgr. d'Arras, who also sent a copy of it to Bossuet.

"Allow me, Monseigneur," the letter says, "to tell you plainly that you are wrong in being reserved with me. Who should speak openly to me if not you, the senior of our province? Believe me, there is nothing you may not unhesitatingly say to me. While, of course, feeling all that has been done, I must honestly tell you that I am more at rest than I was a fortnight ago. My line of conduct is decided. My Superior's decision discharges my conscience; nothing remains for me but to submit, be silent, and bear my cross quietly. May I venture to say to you that this is a condition which carries its own consolation for an 
upright man who seeks nought save God, and does not cleave to the world? My Mandement is now, thank God, all I have to think about, and it is already prepared. I have tried to choose the shortest, simplest, most decided expressions. It would be already published, if I were not waiting the King's orders, which I have asked for through M. de Barbesieux, so as to avoid collision with the customs of this realm with respect to the reception of Bulls and other acts of Roman jurisdiction. This alone, Monseigneur, delays the publication of my Mandement. Doubtless it costs one something to humble one's self, but the least resistance to the Holy See would cost me a hundredfold more, and I must confess that I cannot see any room for hesitation in the matter. One may suffer, but one cannot have a moment's doubt." =

Fénelon sent de Chanterac a private copy of his unpublished Bull, which was not to be circulated, but would enable that devoted friend to speak authoritatively as to the Archbishop's mind, and to quash at once any doubts expressed by unfriendly persons as to the submissive line he intended to adopt. In a long letter accompanying it Fénelon sums up his plans and intentions under four points:I. Full submission; 2. No attempt to seek any advantage or self-interest; 3 . While desiring earnestly

I Correspondence, vol. x. p. 464 . 
not to give any further offence to the King, to do nothing bearing the semblance of unduly seeking his favour, which would simply prove him unworthy of past confidence; 4 . To endeavour on all occasions to show that his heart was free from pride or resentment towards his opponents, while at the same time yielding nothing that concerned his conscience or sense of truth in order to win them, to which end he could enter on no negotiations. Short of this, he was ready to meet them everywhere in the humblest and most pacific spirit.

From first to last, while expressing his absolute submission to the Pope, and his unresentful spirit towards Bossuet and his other enemies, Fénelon steadily refused to utter one syllable which could be perverted into a semblance of retractation. "I will never purchase a few vague compliments at the price of meanness or ambiguous admissions," he wrote to de Chanterac (April 4, I699), "I would rather bear my cross, and justify myself in the eyes of my flock by my patience, my work, and my conduct, as utterly opposed to illusion. But, thank God, I do not prize the world enough to beg for help to raise my head. .... My opponents wish to lead me to say something ambiguous, in order to have it supposed that I acknowledge that I was wrong, and that they were right in their rigorous treatment of me."

I Correspondence, vol. x. p. 476 . 
On the 8th of April Fénelon received an ungracious message from the King through de Barbesieux, to the effect that the sooner the whole business was done with the better! Upon this Fénelon published his Mandement, which, as we know, was only waiting the King's permission, and on the 9 th it appeared.

"Owing ourselves unreservedly to you, dear brethren, as we do," (so the Mandement ran,) "inasmuch as we belong not to ourselves, but to the flock committed to us, we esteem ourselves as your servant in the Love of Jesus Christ. And in this spirit we feel constrained herein to open our heart to you, and tell you all that concerns the book entitled Explication des Maximes des Saints. At last our Holy Father the Pope has condemned this book, together with the twenty-three propositions extracted from it, in a Brief dated March I 2, I699, which is sprcad abroad everywhere, and which you have already seen.

"We give our adhesion to this Brief, dear brethren, both as regards the text of the book and the twentythree propositions, simply, absolutely, and without a shadow of reserve, and we forbid the faithful of this diocese to read or retain the book. We ourselves, dear brethren, shall be consoled under our humiliation, provided the ministry of the Word which we have received of the Lord for your sanctification 
suffer not in consequence, and provided that, notwithstanding the humiliation of the pastor, the flock grow in grace before God.

"Therefore with our whole heart we exhort you to a sincere submission and unreserved docility, for fear the single-mindedness of obedience to the Holy See insensibly suffer; in which we desire, by God's Grace, to give you a full example to our last breath.

"God grant that we may never be spoken of save as a pastor who strove to be more docile than the least sheep of the flock, and whose submission knew no limit.

"Dear brethren, may the Grace of our Lord Jesus Christ, the Love of God, and the Fellowship of the Holy Ghost be with you all. Amen.

"FrançoIs, Archbishop and Duke of Cambrai."

On the IIth April Fénelon sent the published Mandement to the Pope, together with a private letter, of which he says himself to de Chanterac, that in writing it he had endeavoured to show neither pride nor vexation, but at the same time to avoid all appearance of meanness, flattery, or empressement. It is not without a certain sense of wounded dignity that in the same letter, referring to the Pope's repeated assertions that he held the Archbishop to be piissimo, santissimo, dottissimo, Fenelon says:- "If my patience, my 
teaching, and my example cannot uphold me amid my flock, apart from any such laudation, it will certainly not uphold me."x

But in truth, even at the time, as assuredly in history ever since, no one came out of the whole of this, which Louis XIV. so truly called a "disagreeable affair," with such unblemished reputation and grace in the sight of God and man as he for whom, by dint of every injustice and subterfuge and terrorism practicable, his Eminence had at length obtained a so-called condemnation.

The Chancellor d'Aguesseau does not hesitate to say that the King received the condemnation "with joy." "The Archbishop of Cambrai," he says, "who had fought like a lion in defence of his book so long as he had a hope of victory, proved the superiority of his character by submitting, as he himself said, like the humblest sheep of his flock. He did not even wait till the King should have taken any step to sanction the Brief in his kingdom. Although no decree from the Court of Rome can be received in it without the sovereign's consent, he, forestalling that consent, committed one of those well-timed errors which none save great men ever risk; and being unable any longer to avert the condemnation of his colleagues, he hastened to appropriate the dignified - Correspondence, vol. x. p. 497 . 
position of being the first to condemn himself. His brief and touching Mandement consoled all his friends, discomfited all his enemies, and gave the lie to the prediction too hotly uttered by the Bishop of Meaux, that if Cambrai were condemned, the world would soon see the difference between his theory and practice, and all the various subtleties appertaining to theological discussions." $x$

D'Aguesseau spoke the truth. Fénelon's line was most disconcerting to his enemies, though scarcely, any voice save Bossuet's dared make itself heard in criticism or depreciation. Cardinal de Noailles remained silent, but Godet-des-Marais (Bishop of Chartres) wrote a few lines, intended to be cordial and affectionate, expressing himself as ravi at Fénelon's line of action, and assuring him that words would not express how touched he was at such humble and generous conduct. There is great dignity in the Archbishop's brief answer:-

"I have just received the letter you do me the honour to write, and hasten to send my humble thanks. Although I have endeavoured to act solely with reference to God in what I have done, I am, nevertheless, glad, Monseigneur, to see by the words you use how much you approve my conduct. Permit me, I beg, to commend myself to

${ }^{2}$ Euvres d' Aguesseau, vol. viii. p. 208. 
your prayers, and to assure you of the sincerity with which I am always," etc., etc. ${ }^{2}$

At Rome the greatest satisfaction was felt and expressed, and the large number of Cardinals who thought that Fénelon had been unjustly treated, were joined by their colleagues in a unanimous vote, that the Pope should be requested to send an "honourable" answer to the Archbishop's letter of submission. The Pope was only too glad to appease his own conscience and feelings by any act favourable to one whom he had been so reluctantly forced to injure, and he commissioned Cardinal Albani to draw up a Brief as complimentary and soothing to Fénelon as possible, which the Cardinal accordingly did; but the Abbé Bossuet got wind of the matter, and while writing to his uncle in the greatest alarm on the subject, even intreating him to induce the King to forbid such a measure, and suggesting whether it would not be possible to depose the Archbishop, he made good use of his opportunities on the spot to frighten different Cardinals, and through them the Pope, as to the extreme displeasure any favour shown to Fénelon would excite at the Court of France, and the terrible consequences which might ensue. The Brief was actually prepared and registered, but the petty spite of the Abbé Jacques succeeded in preventing its ${ }^{\prime}$ Correspondence, vol. x. p. 518 . 
being sent. However, Cardinal Albani roused himself to represent to the aged Pope, whose fears were thus worked upon, that so much deference to a foreign Court, and such obvious timidity, was both undignified and dangerous, and Innocent summoned up courage to send his Brief, albeit mutilated and let down from its first jubilant tone. ${ }^{x}$ But even this welldiluted and somewhat feeble document was intensely irritating and annoying to those in France who wished,

1 The letter was as follows:- "Venerabilis Frater, salutem et apostolicam benedictionem. Ubi primum accepimus fraternitatis tuæ, Mense Aprili proxime elapso, ad nos datas litteras, unaque cum illis exemplar Mandati, quo apostolicæ nostræ, libri a te editi cum viginti tribus inde excerptis propositionibus, damnationi humiliter adhærens, eam commisso tibi gregi prompto obsequentique animo edixisti; summopere læatati sumus. Novo siquidem hoc debitæ ac sinceræ tuæ erga nos et hanc sanctem sedem devotionis atque obedientiæ argumento, illam quam de Fraternitate tua jampridem animo conceperamus, opinionem abınde confirmasti. Nec sane aliud nobis de te pollicebamur; qui ejusmodi voluntatis tuæ propositum diserte explicasti, ex quo ab hac cæterarum matre et magistra Ecclesia doceri ac corrigi demisse postulans, paratas ad suscipiendum verbum veritatis aures exhibuisti; ut quid tibi aliisque de libro tuo præfato, contentaque in eo doctrina sentiendum esset, prolato a nobis judicio statueretur. Tuæ itaque solicitudinis zelum, quo pontificiæ sanctioni alacriter obsecutus fuisti, plurimum in Domino commendantes, pastoralibus laboribus ac votis tuis adjutorem et protectorum omnipotentem Deum ex animo precamur; tibique, venerabilis Frater, apostolicam benedictionem peramanter impertimur. Datum Romæ, sub annulo Piscatoris, die I2 Maii, anno 1699 , pontificatus nostri anno octavo." 
if possible, to crush Fénelon entirely. They went so far as to aim at inducing the Pope entirely to reject his Mandement, and overdid their attempts to such an extent, as to convince even those Cardinals who had taken part against Fénelon that personal malice was at the root of the whole business. Consequently every member of the Sacred College, with the single exception of Cardinal Casanata, sent messages of sympathy, veneration, and esteem to the Archbishop of Cambrai, through de Chanterac, before he finally quitted Rome, May 15, 1699.

Meanwhile the troubles raised were not quite quieted in France. Much discussion was held at Versailles as to how the Brief of condemnation was to be received. Government and clergy alike desired to adhere to the famous Declaration of $\mathbf{1 6 8 2}$, which required the formal acceptance of the Episcopate of France before any judgment issued by the See of Rome could be received as ruling doctrine; and further, it required that such acceptance should take the form of an examination and certificate that the Bishops of France recognised the faith and tradition of their own Church in the Pope's judgment. It was decided at last that the King should authorise all Archbishops to assemble the Bishops of their respective provinces, to examine and accept the Brief. Accordingly, the King issued letters commanding 
the Archbishops to convoke their metropolitan assemblies. That of Paris met on the $13^{\text {th }}$ May. "The provincial assemblies were held in each province, with perfect unanimity, alike as to the condemnation of the Archbishop of Cambrai's book as to the preservation of episcopal rights, and as to the judgments which concerned the doctrine or liberties of the Gallican Church," says d'Aguesseau. " "On the latter point, indeed, there was a laudable emulation among the various provinces, each desiring the honourable reputation of having best sustained the episcopal power to judge either before the Pope, or with him, or after him, as also the right of not receiving papal constitutions, save subject to examination and a formal judgment."

The Paris Assembly, mainly composed of Fénelon's chief and acknowledged antagonists, Paris, Meaux, and Chartres, sought to add to the Pope's judgment a condemnation he had expressly omitted, of the various writings Fénelon had put forth in defence or explanation of the original book. Either the bad taste or the injustice of this proceeding was not acceptable to the Episcopate generally-one half of the metropolitan assemblies refused thus to amend the judgment of Rome. As if God in His Providence was pleased to allow the pious Fénelon to drain the cup of humi× Euvres, vol. viii. p. 209. 
liation, so bitter to a worldly-minded man, his own province was still destined to put his patience and humility to the proof. $\mathrm{He}$ did not hesitate for a moment to obey the royal mandate, and summon his provincials to condemn his own book, scarcely expecting, probably, that Monseigneur de Valbelle, Bishop of Saint Omer (who is characterised by d'Aguesseau as " a clever man, but hot as a Provençal, which he was, and argumentative as a Norman," ) would exceed his orders and the Pope's utterances so far as to beset his Metropolitan in a most insolent manner, in order to induce him to say that he had actually fallen into the errors imputed. ${ }^{2}$ The great Chancellor affirms that Fénelon answered Saint Omer's "pressing and odious interpretations" with wisdom and dignity; adding, that the other Bishops, indignant at Monseigneur de Valbelle's proceedings, rallied round their Archbishop, and quashed the matter. It is melancholy to find that this onslaught was prompted by Bossuet, his letter

I Euvres, vol. viii. p. 2 Io.

2 “". . . Les indignes tracasseries qu'il lui fit aans l'assemblée provinciale de Cambrai, où il vouloit non seulement que ce prélat se soumît à sa propre condamnation, comme il l'avoit déjà fait de si bonne grâce, mais qu'il avouât encore qu'il étoit veritablement tombé dans les erreurs que le Pape avoit condamnés, faisant ainsi le procès à ses intentions mêmes en lui arrachant la foible consolation de pouvoir dire au moins qu'il avoit bien pensé s'il s'étoit mal exprimé." 
urging the Bishop of Saint Omer to the attack being extant. ${ }^{x}$

D'Aguesseau gives an interesting account of the proceedings which went on behind the scenes in framing the letters patent which were to confirm the ecclesiastical judgments by royal authority, he himself having the principal share in drawing these up. Always ungenerous and prejudiced towards Fénelon, Louis XIV. found no fault with d'Aguesseau's papers except that they spoke too kindly of the Archbishop of Cambrai. In relating the whole history, d'Aguesseau honestly says that, besides liking him personally (" et il faut avouer que son commerce étoit délicieux," he adds), he could not but remember that some day the man now the mark for obloquy would very likely come to the front, and that therefore prudence dictated abstaining from giving needless offence. Nevertheless, he was obliged to retrench somewhat to satisfy the King.

His Discours ${ }^{2}$ was published with the formal documents, and the whole was presented to the Parliament, Aug. 14, 1699. "Thus was the condemnation of the Archbishop of Cambiai's book completed," writes d'Aguesseau in his Mémoires sur les Affaires de 'Eglise de France,- "a solitary instance, perhaps, of

x Correspondence, vol. x. p. 577.

2 See Euvres, vol. i. p. 258. 
a doctrinal dispute being finally closed by a single judgment, which no one has since sought either to have retracted or to elude by any specious explanations. The credit of this is due to the wisdom and superiority of mind of the Archbishop of Cambrai, who was able to see that an over-great desire to justify one's self often does more harm than good, and that the surest way to obliterate wrongs unjustly imputed is to let them be forgotten and die out in silence; while, furthermore, his knowledge of men must have taught him that he was likely always to be condemned by more than three-quarters of his judges, because there would always be a full three-quarters incapable of understanding him." $x$

A letter from Fénelon to de Chanterac, giving an account of his own provincial assembly of the 29 th May, describes the events of the last month with wonderful moderation, summing up with the touching words:- "One must bear everything without murmur, maintain a loving submission to our Mother Church, and accept humiliation with humility. Come -oh, come! To embrace you, talk with you, live and die with you, will indeed be a comfort !"2

Nor was this meek, unworldly spirit merely a passing frame of mind, destined to pass away. Not

Euvres, vol. viii. p. 218.

2 Correspondence, vol. x. p. 585 . 
unnaturally, a much less submissive feeling existed among many others, - some personal friends of the noble-hearted sufferer, some strangers to all but his public character,-and many champions were desirous to enter the lists in his defence. But Fénelon never swerved in his attitude of patient submission, and to all he returned the same answer, that he wished nothing to be said or done on his behalf. A specimen of his views on this subject may be given in the subjoined letter to a certain Abbé de Chevremont, who wrote to him concerning a work on Quietism he was preparing :-

$$
\text { "Cateau, July 2, } 1699 .
$$

"I am deeply touched, sir, by the tokens of friendship and zeal shown by you. But allow me, I intreat you, to speak unreservedly, and from the bottom of my heart. I condemned my book in perfect good faith, out of submission and docility to the Pope. Consequently, whoever bears me any friendship cannot show it more truly than by never uttering another word in its favour. I cannot consent even to an indirect justification of it. Further, I beseech you neither to say nor write anything against my colleagues who attacked me at Rome, nor against the Archbishop of Rheims. You know, sir, how strongly religion requires a spirit of peace, charity, and respect for the Episcopate. Whatever you might do out of zeal 
for my interest would recoil upon me, for it would inevitably be imputed to me. . . . In God's Name, I intreat you to speak of me to none save God." :

The same language we find in all Fénelon's letters of this period, and that in reply to many most flattering and warmly approving from a great variety of ecclesiastics-Cardinals, religious, and others. Undoubtedly he was, as one eminent person wrote from Rome," "more glorious than if he had never been condemned."

It was nearly a year later that, in the great Assembly of Clergy sitting at Saint Germain-en-Laye, the subject was renewed, more, however, in accordance with the custom of a reference to all ecclesiastical events of importance which had occurred since last the Assembly met than with any special object. Bossuet was selected to introduce the subject, and one is thankful, for his sake, to be able to record that he did it with moderation, and perhaps with a secret desire in some way to repair the injustice and harshness of the past.

After that the subject died out. Fénelon lived

- Correspondence, vol. xi. p. 3 .

- À l'Abbé de Chanterac, du P. Bellissen, Procureur-Général de la doctrine Chrétienne. Rome, Juillet 4, I699. - Ibid. p. 5 . 
down any possible questioning of the orthodoxy and purity of his faith and practice, and no unkind word respecting any of his persecutors seems ever to have escaped him. Once, some one who had mentioned Bossuet's talents with admiration in the Archbishop's presence, expressed some fear lest he should have thought such mention a breach of good taste. But Fénelon was distressed at such a notion being possible. "What can he think of me," the Archbishop exclaimed, with considerable emotion, "if he shrinks from mentioning before me a man whose genius and vast knowledge must for ever be an honour to his age and his country, as well as to all the Church!"

Such faint grounds as exist for imagining that Bossuet desired a reconciliation with the friend he had so grievously injured have been already brought together in the Life of Bossuet, ${ }^{I}$ and need not be repeated here. Assuredly Fénelon forgave him, with all others who had ever wounded him. When Bossuet died (April I2, r704), a report got about that the Archbishop of Cambrai had held a solemn service for him, and preached his funeral oration. The Benedictine Père Lami wrote to ask Fénelon as to the truth of these reports, and he answered, that though he had prayed most heartily for the late Bishop of Meaux, he had certainly not asked the public prayers

${ }^{x}$ Bossuet and his Contemporaries, p. 462. 
of his diocese on Bossuet's behalf, such a proceeding being quite unwonted, " and you know I do not like affectation or out-of-the-way doings. Still less did it occur to me to deliver a funeral oration."

"Yet deem not, on such parting sad

Shall dawn no welcome dear and glad:

Divided in their earthly race,

Together at the glorious goal,

Each leading many a rescued soul,

The faithful champions shall embrace."

Correspondence, vol. iii. p. 43. 


\section{CHAPTER V.}

DROBABLY there were many in France, both in political and ecclesiastical circles, who believed with D'Aguesseau that nothing was more probable than that, after the great storm had been dispersed, Fénelon would return to Court, and be a more influential and favoured personage than ever. But those who could think thus did not know him, or perhaps know the real character of the Court and its principal actors.

Fénelon had loved individuals in that Court-indeed he loved the Duc de Bourgogne with a father's devoted love to the end, and felt a father's grief when the young Prince was taken from this world in the flower of his age; he had had a respectful, appreciative affection for Mme. de Maintenon, and a loyal devotion at least for Louis XIV.; but he had no love for Court favour per se-for its dignities, or pomp, or pleasures, and his whole life bears witness 
to the truth of his often-repeated assertions, that he had no wish to return to Paris or Versailles.

Louis XIV. was too autocratic ever to forgive the man who had so meekly but so entirely withstood him; and it was not in the Grand Monarque's nature either to conquer a prejudice such as had been instilled into him against Fénelon so long ago as when he was a simple young Abbé by de Harlay. Moreover, the King was unquestionably jealous of his influence over his grandson the Duc de Bourgogne.

Mme. de Maintenon probably could and did better appreciate the nobility of Fénelon's heart and conduct, and would feel that all her early opinions concerning his disinterestedness and purity of mo tives were more than justified. But she had wronged him too cruelly to forgive herself, $x$ however entirely he might forgive her; and even had her woman's tenderness overcome her pride, and enabled her freely to acknowledge her faults and crave Fénelon's forgiveness, she dared not have taken a step so utterly offensive to the King as to reconcile herself with one whom he chose to visit with his displeasure.

The Cardinal Archbishop of Paris could surely never think of Fénelon without consciousness of the

I Saint Simon says he was "odieux au roi, ... plus odieux à Mme. de Maintenon, parce qu'elle l'avait perdu."-Mémoires, vol. xvii. p. 176. 
weakness and vacillation with which he himself had acted through the last few years; and his family, if not he, were jealous of the influence which any reunion between Mme. de Maintenon and the Archbishop of Cambrai would tend to promote. Some rather contemptible efforts he seems to have made to make the latter believe that he had been unwillingly forced into the line he took; but though Fénelon had put away past grievances, he did not care to solicit the favour of those who had ill-treated him, and nothing came of Cardinal de Noailles' little schemes.

The Bishop of Chartres alone, perhaps, was free from personal motives as respected Fénelon, for whom his respect and friendship had never quite perished; and, a really good religious man himself, he could not help knowing and believing that the man he had helped to overthrow was good and deeply religious too. But he had not the courage boldly to make advances, which would doubtless have been met cordially; he pottered on with timid messages sent through the Curé of Versailles ${ }^{x}$ (Hébert), to which Fénelon replied frankly and heartily, saying that "no vexed memories of the past were on his mind-he should think it a sin to cherish such."” But nothing more ensued then, and some slight intercourse respecting one of his clergy is all that

I Correspondence, vol. ii. p. 458 .

Ibid. vol. xi. p. 45 . 
ever appears to have taken place between the two afterwards. In Fénelon's letter to the Bishop of Chartres on this occasion he says:- "I feel as I ought, Monseigneur, the tender expressions with which you are pleased to allude to our intimate friendship of more than thirty years. God knows that I have never ceased to respect you duly, and I pray Him to fill you abundantly with His Grace for the service of the Church."

But a fresh episode was in store which was to confirm Louis XIV. in an unchangeable aversion and mistrust of Fénelon. This was the publication of his famous story Télémaque. Perhaps now, when this once celebrated book is seldom read, save as a perfectly harmless-however beautifully written -and (be it honestly confessed) a rather dull schoolroom book, it is difficult to appreciate either the intense admiration $^{2}$ or the bitter wrath which it excited at the time of its appearance. Mythological stories were more to - the taste of that period than they are to that of our own, and unquestionably the language in which Télemaque is written is graceful and flowing, like

I Correspondence, vol. iii. p. 33.

2 Even making allowance for French exuberance, it is difficult to understand how at any time it could be said by the most enthusiastic-"Si le bonheur du genre humain pouvait naître d'un poème, il naîtroit de Télémaque," with the Abbé Terrasson. 
everything which came from Fénelon's pen. ${ }^{x}$ The precise time at which the story was written is not known, but in a letter (or rather mémoire) written to Père le Tellier in $\mathrm{r} 7 \mathrm{ro}$, Fénelon says concerning it :"Teiémaque is a story in the form of an heroic poem, like those of Homer and Virgil, in which I introduced the principal points of teaching suitable to a prince destined to the throne. I wrote it at a time when I was rejoicing in the many marks of confidence and kindness which the King showered upon me. I must have been not merely the most ungrateful, but the most foolish of men, if I had intentionally drawn satirical or insolent portraits in it. I abhor the mere notion of such a thing. It is true that $I$ introduced all the virtues necessary for a good government, and the faults to which sovereign power is liable, but none were drawn with the slightest approach to any personality or portraiture. The more the book is examined the more it will be seen that I only ex-

× Sainte-Beuve says :- “Je n'ai rien dit de Télémaque, ce cours de thèmes comme il n'y en a jamais eu, qui n'est, à le bien voir, que la plus longue des fables de Fénelon, l'allégorie développée, devenue épique, et où l'auteur, abordant par les douces pentes de l'Odysée la grandeur d'Homère, de cet Homère qui d'un seul trait met la nature toute nue devant les yeux, n'a fait, en le réduisant un peu, que lui donner la mésure et comme la modulation virgilienne, et le ramener en même temps aux convenances françaises, telles que les entendaient les lecteurs de Racine." -Nouveaux Lundis, vol. ii. p. I3r. 
pressed principles fully, without attempting to draw any finished character. It is simply a story rapidly written, in detached fragments, and at intervals-a story needing a great deal of correction. Moreover, the printed version is not accurate as compared with the original. My only object was to amuse the Duc de Bourgogne with a tale of adventure, and to instruct him at the same time, without ever thinking of giving the work to the public. Everybody knows that this was only done through the treachery of a copyist." $x$

No one can entertain a doubt that this is the true history of Télémaque. Nevertheless a very different view was held and circulated at the time. The book was, as Fénelon says, treacherously published, a man trusted to make a fair copy having been clever enough to perceive its merits, and having privately handed it about in manuscript as early as October 1698. Emboldened by the success of this first piece of dishonesty, the man actually presumed fraudulently to sell his stolen MSS. to the publishing firm of Claude Barbin in Paris, without, of course, betraying his own secret, or saying who the author was. That did not concern the publisher, who easily obtained the usual license, and the first edition was printed bearing the date April 6, 1699. The MS. was printed off as far as the 208th page, when the fact of its authorship got

× Correspondence, vol. iii. p. 247. See also vol. ii. p. 459. 
wind, and as at that very moment the height of the storm concerning the Maximes was raging, the proofs were seized, the printers imprisoned, and every possible measure taken to efface the whole thing. Nevertheless some proofs escaped the police, and a very limited edition was sold,--under such exciting circumstances, as a priceless treasure. The injured publishers hastened with the greatest secresy to sell the complete manuscript to a bookseller at the Hague, Adrien Moëtjens by name, who, with the greatest speed possible, brought out the whole work in June, and no one pretending to the smallest literary acquirement but had read and admired the book before the summer was over.

It was a delightful weapon for his enemies to handle against him! Saint Simon (while passing lightly over the book as a quantity of old stolen themes patched together, and published without Fénelon's knowledge) says that the Maréchal de Noailles, who coveted the Duc de Beauvilliers' offices, went about telling the King and all who would listen that none save one who was the monarch's personal enemy could have written it ! ${ }^{2}$ Every one who desired to damage the Archbishop, or to perpetuate his estrangement from Court, sang the same song. Old Le-Dieu, Bossuet's secretary, records, January 23, I 700, not Mémoires, vol. xvii. p. 176. 
only his master's criticisms on the style of Telémaque, which Bossuet pronounced "effeminate and poetical," and unworthy of a Bishop by reason of its love scenes; but further, that he did not hesitate to pronounce "le roman de $M$. de Cambrai" to be a covert censure of the actual Government, the King and his ministers. What on earth could possess $\mathbf{M}$. de Cambrai to publish such a thing at such a time, unless it were to prove to the public that he was the best writer of his day, and affect to be the only man honest enough to tell the truth ! ${ }^{\text {r }}$

People went on to say that Fénelon had written the satire since his disgrace, as a piece of revenge upon Louis XIV. and his surroundings. Mme. de Maintenon was easily persuaded of this. Fénelon says, writing to the Duc de Bourgogne, that Telémaque had " irritated " her; ${ }^{2}$ and the more all Europe persisted in admiring the book and in bringing out fresh editions and translations-for the demand became almost unlimited-the more embittered Louis XIV. and his queen-like wife became.

It is scarcely necessary now to go into any elaborate process of proof that Fénelon had absolutely no personal satire in view when he wrote Telémaque. Probably no one free from the turbulent prejudices of

' Journal de l'Abbé Le-Dieu, vol. i. p. 12.

$=$ Correspondence, vol. i. p. 97 . 
that period would be inclined to question the matter; and the circumstances attendant upon his writing the book, i.e. merely as an unpublished MS. for his royal pupil's amusement, together with his unfailing loyalty and respect in deed and word to the King, would be enough to satisfyany dispassionate and reasonable mind.

But Louis XIV. never could forget or forgive it, and the enforced separation already so painful to the Duc de Bourgogne between him and his beloved Preceptor, was more urgently pressed even than before, with the inevitable consequence (which one would have thought the King's acquaintance with human nature might have taught him) of binding the bonds of that devoted affection closer than ever. That this was the case need not be doubted by those who read the following letter, written by the Duke to Fénelon.

\section{"Versailles, Dec. 22, I 7or.}

"At last, my dear Archbishop, I have found an opportunity of breaking the silence of four years. I have suffered many things meanwhile, but one of my greatest trials has been that I was unable to tell you all I felt for you all the time, and that, so far from slackening, my love for you grew stronger under your troubles. I look with eager pleasure for the time when I may see you again, but I fear it may yet be far off. We must leave it to God's Will; His Mercy is ever 
heaping fresh favours on me. I have been repeatedly faithless to Him since I last saw you, but $\mathrm{He}$ has always mercifully recalled me, and I thank Him that I have never been deaf to His Voice. Latterly I think I have been more persevering in the right way. Ask God graciously to confirm my good resolutions, and not to allow me to be His foe any more, but that in all things $\mathrm{He}$ would teach me $\mathrm{His}$ holy Will.

"I go on studying by myself, although for the last two years I have left off regular lessons; and I like it better than ever. Nothing interests me more than metaphysics and moral theology. I should never grow weary of them. I have written some little papers on these subjects, which I wish I could send for you to correct as you used to do my themes. All this is very disconnected, I am afraid, but that does not matter much. I will not begin to say here how all that has been done about you revolts me; we must submit to God's Will, and believe that it has all happened for our good. Do not show this letter to any one whatsoever, except the Abbé de Langeron, if he is at Cambrai, for I am sure of his secresy. Remember me very kindly to him, and assure him that absence does not weaken my friendship for him. Neither must you answer this letter, unless by some very safe channel, and putting your letter into M. de 
Beauvilliers' packet, as I do with mine; for he is the only person in whom I can trust, and I know how he would be damaged if it were known. Adieu, my dear Archbishop. I embrace you with all my heart. Perhaps it may be long before I get another chance of writing to you. I ask your prayers and your blessing.

Louis."

The answer to this simple, boyish letter is hardly less simple, and marvellously characteristic of the writer :-

$$
\text { "CAMbrai, fan. 17, I702. }
$$

"Nothing has been a greater comfort to me than your letter which I have just received. I thank Him Who Alone can mould hearts as $\mathrm{He}$ will to His own Glory. He must love you very much, since $\mathrm{He}$ fills you with love for Him amid so much that seems likely to banish His Love from your heart. Love Him above all things, and fear nothing save the loss of that love. It alone will be your light, your strength, your life, your all. Oh, how rich and powerful even amid crosses the heart is which bears that treasure within it! Even so you must accustom yourself to seek Him with the simplicity of a child, with a tender familiarity and a confidence acceptable to so loving a Father.

' Correspondence, vol. i. p. II6. 
"Do not be disheartened by your failings. It is possible to bear without giving way to them, and to correct them without impatience. God will point out this peaceful, effectual course, if you seek it in hearty mistrust of self, and walking with Him like faithful Abraham.

"In God's Name, I beseech you let prayer nourish your soul as your meals nourish your body. Let your fixed seasons of prayer keep you in God's Presence through the day, and His Presence, frequently remembered through it, be an ever-fresh spring of prayer. Such a brief, loving recollection of God renews a man's whole being, quiets his passions, supplies light and counsel in difficulty, gradually subdues the temper, and causes him to possess his soul in patience, or rather gives it up to the possession of God. Renovamini spiritu mentis vestra. Do not try to make long meditations, but every morning get some quiet time for a brief one-that short season will feed you through the day. Let this meditation be more a matter of heart than intellect,-less of argument than simple affection,- - little of methodical arrangement, a great deal of faith and love.

"You must read, too, and that books which will strengthen you, teach you recollection, and draw you nearer to God. You have a person at hand who can point out suitable reading. Do not be afraid of 
frequenting the Sacraments according to your need, and as you feel drawn to them. Let no vain human respect deprive you of the Bread of Heaven, Who deigns to give Himself to you. Never make any uncalled-for demonstrations, but at the same time never be ashamed of Him Who Only is your glory.

"What gives me the greatest hopes is that I see by your letter that you know your failings, and acknowledge them humbly. How strong one is in God when one realises one's own weakness! Cum infirmor, tunc potens sum. Fear to fall a thousand times more than death. But if you should unhappily fall, hasten to return to the Father of Mercies and the God of Consolation, Who will stretch out His Arms to you, and open your wounded heart to those who can heal you. Above all, be humble and lowly. Et vilior fiam plus quam factus sum, David said, et humilis ero in oculis meis. Apply yourself diligently to your duties, take care of your health, and restrain your tastes, so as not to exhaust your strength. I speak to you only concerning God and yourself, it does not matter about me. Thank God, my heart is at rest; my heaviest cross is not seeing you. I have you continually in mind before God, in a closer union than anything of this life. I would give a thousand lives as freely as a drop of water to see you such as God 
would have you be. L. de L. (Langeron) is full of gratitude for your remembrance. Amen, Amen." ${ }^{x}$

Two more letters to the Duke, written about the same time, will still further show what the nature of this influence was from which prejudice could make Louis XIV. so anxious to preserve his grandson!

"I believe, Monseigneur, that the true way of loving your neighbour is to love him in God and for God. Men know so little of the Love of God, and for want of knowing that they are afraid of Him, and draw back from Him. This fear hinders them from understanding the sweet familiarity with which His children rest in the Bosom of the tenderest of all Fathers; they can see nothing but an all-powerful and stern Master; they are always constrained with Him, hampered in all they do. They do what is right reluctantly, to avoid punishment ; they would do wrong if they dared, and if they could hope to do it with impunity. The Love of God is to them a burdensome debt ; they seek to evade it by formality, and by an exterior worship which they strive to substitute for a hearty, active love. They bargain with God Himself, in order to give Him the least they can. O God, if men knew what it really is to love Thee,

'Correspondence, vol. i. p. II 8 . 
they would ask no other joy in life save Thy Love!

"This love only demands of us an innocent and well-regulated habit of life. It only requires us to do for God what common reason would enjoin. It is not a question of adding to our good works, but rather of doing for love of God that which upright people who lead good lives do from a sense of honour and self-respect. All that has to be given up is that evil which we should give up from a mere principle of reason. And for all the rest, we may leave things in the order of God's Providence, doing all that is right and good, but so doing for His Sake Whose we are and to Whom we owe everything.

"This love of God does not exact of ordinary Christians austerity such as the hermits of old practised, their solitude nor their contemplation; it does not ordinarily require either startling heroic deeds, nor a renunciation of rightfully acquired property, or of the advantages appertaining to each man's natural position. It only requires of each to be honest, sober, and temperate in the right use of all these things; not making an idol of any of them, but using them as God would have him, in His service.

"Such love as this does not increase our crosses, it finds them broadcast already among all conditions of men. Our crosses arise from the infirmity of our 
bodies and the passions of our hearts ; from our own imperfections and those of others with whom our lot is cast. It is not the love of God which causes these trials ; on the contrary, it softens them by the comfort $\mathrm{He}$ mingles with our sufferings. Indeed, it lightens our crosses as by degrees it moderates our ardent passions and our sensitiveness, which are at the bottom of all our real troubles. If we had a perfect love of God, it would put an end to all our sorrows and fill us with blessed peace, by teaching us real detachment from all alike that we fear to lose or long to gain.

"Why, then, should we fear that love, which causes none of our trials, which can soften them all, and which would bring all possible blessings with itself into our hearts? Truly men are their own great enemies when they fear and resist this love.

"The precept of love, so far from being a weight over and above all other precepts, tends, on the contrary, to make those others sweet and light. What we do from fear, and without love, is always wearisome, hard, grievous, oppressive. What we do out of love, from persuasion, with a free will, however hard to the senses, becomes pleasant. A desire to please God because we love Him makes one love to suffer, and what we suffer for love's sake ceases to be suffering.

"This love alters, disturbs, changes nothing in the order of things God has established. It leaves the 
great to their greatness, only causing them to be lowly in His Hand Who has made them great. It leaves the lowly in the dust, and makes them rejoice to be nought save in Him. Such content in the lowliest place is altogether free from meanness, and is true greatness.

"This love rules and inspires all other love. We never love our neighbour so well as in God and for Him. When we love men apart from this, we love them for ourselves only; we seek either our own obvious interest, or a subtle, hidden self-interest. If it is not money, favour, advantage that we seek, it will be the credit of disinterestedness, or gratification of taste, or confidence, the pleasure of being liked by people of merit-things which are more soothing to self-love even than a round sum of money. So that after all it is self that we love all the time; and such love is a very poor thing, it is much more vanity than real love.

"What, then, is the true way of loving one's friends? It is to love them in God, to love God in them; to love what $\mathrm{He}$ has made them, and to bear, for love of $\mathrm{Him}$, with what $\mathrm{He}$ has not made them. When we only love our friends out of self-love, that selfishness which is impatient, fastidious, jealous, exacting, and worthless, will be for ever mistrustful both of itself and its friend; it grows weary, and is easily put out; it 
soon comes to an end of what seemed boundless; it is for ever lost in misunderstandings; it wants perfection, and cannot find it; it grows petulant and changeable, and finds rest nowhere. But the love of God, loving friends apart from self, knows how to love patiently through all their faults. It does not want to find more in them than God has put there; it sees Him and His gifts above all; all is welcome so long as we love what $\mathrm{He}$ does, and bear with what $\mathrm{He}$ withholds, knowing that $\mathrm{He}$ withholds it only the more to conform us to His Will.

"This love which comes of God never looks for perfection in anything created, it knows that perfection is God's only; and imperfection only causes it to cry out, That is not my God! Expecting no perfection, it is never disappointed. What is lacking in any one it knows may yet be made up, if God so wills. He who has such love loves all that God has made, and chiefly those whom God gives him for special love. In an earthly father he sees reflected a Heavenly Father; in brothers, relations, friends, the close links which God's Providence has knit. The closer such links the deeper and stronger His Providence makes them. Can we love God, and not love all that $\mathrm{He}$ has given us to love?

"Verily, we had rather die than love aught better than we love Him. He has said in His Gospel, 'If 
any man love father or mother more than $\mathrm{Me}$, he is not worthy of Me.' God forbid, then, that I should love more than Him that which I should love for His Sake only. But I love with all my heart whatever represents $\mathrm{Him}$, whatever is $\mathrm{His} \mathrm{Gift}$, whatever $\mathrm{He}$ wills me to love. And this solid foundation of love makes me careful to fail in nowise either towards relations or friends. Their imperfections cannot surprise me, for I look for imperfection in all that is not God. In Him Alone I see any real goodness, but I love Him in His creatures, and nothing can affect that love. It is true that this love is not always equally tender and quick; but it is real, deep, faithful, constant, practical, and I prefer it to all other love. At times it has its sweetness and its transports. A soul wholly stayed on God would never be cold and dry with the inequalities and touchiness of self-love. Loving for God's Sake only, it would love, like God, with a perfect love; for, as S. John says, 'God is Love.' Its heart would be a spring of living water, according to the promise. Such love would bear all, endure all, hope all for its neighbour; it would overcome all difficulties; the depths of the heart would overflow a man's exterior; he would be tender over the troubles of others, unmindful of his own; he would mould himself to all men, lowly with the lowly, great with the great, he would weep with those that 
weep, and rejoice out of sympathy with those that rejoice; he would be all things to all men, not in cold, outward show, but out of the abundance of a heart in which the Love of God was the living source of all the tenderest, keenest, and strongest feelings. Nought so dry, so cold, so hard, so shut up, as a heart which loves itself alone. Nought so tender, open, quick, sweet, loveable and loving, as a heart possessed of and filled with the Love of God." "

What could be a better though unconscious description of the writer's own most loving heart? Or what wiser lessons could the expected successor of Louis XIV. receive than the following?-

"Son of Saint Louis, imitate your ancestor. Be, like him, gentle, humane, accessible, affable, compassionate, and generous. Never let your grandeur hinder you from coming down to the level of the lowliest; never let such kindliness weaken either your authority or their respect. Study mankind continually; learn to use men without giving yourself up blindly to them. Seek for real worth to the ends of the world-it is apt to be modest and reserved. Virtue does not push through the crowd-it is neither eager nor greedy, and lets itself be overlooked. Do not allow yourself to be beset by insinuating flatterers;

× Correspondence, vol. i. p. I2I. 
let it be felt that you do not like praise or fawning. Only show confidence in those who have courage to contradict you respectfully if need be, in those who value your good name more than your favour. Saint Louis' power and wisdom will be given you, if you ask them, humbly acknowledging your weakness and helplessness. It is time that you show forth to the world a maturity and strength of character suited to the present need. At your age Saint Louis was the joy of good men and the terror of evil men. Let the pastimes of your past days drop-show that you feel and think aright. Make good men love you, bad men fear you-all esteem you. Make haste to correct your own fauits, that you may labour profitably to improve others.

"There is nothing trivial, or gloomy, or constrained about real religion; it makes the heart larger, it is simple and loveable, and becomes all to all that it may gain some. The Kingdom of God does not consist in a scrupulous observance of petty details, but in a due performance of the duties which belong to every condition of life. A great prince is not called upon to serve God in the same fashion as a hermit or an ordinary private individual. Saint Louis worked out his salvation as a great king. He was intrepid in war, decided in council, superior to other men by the nobility of his mind,-without pride, presumption, or 
harshness. In all things he studied the real welfare of his people, whose father he was as well as their king. He saw everything with his own eyes. He was industrious, far-sighted, moderate, upright, and firm in negotiation, so that he was as much trusted by strangers as by his own subjects. No prince ever ruled a people more wisely, or more effectually made them both good and happy. He loved those who deserved his love tenderly and trustfully, but he was firm in chastising those he loved best when they were in fault. He was generous and magnificent according to the fashion of his time, but without luxury or display. His expenditure, though great, was so well regulated that the country was not oppressed. Long after his death his reign was remembered tenderly as a model for all ages. The weights and measures, the laws and customs, the government of the good Saint Louis, were everywhere quoted. May you be the inheritor of his virtues as well as of his crown. Invoke him confidently, remember that his blood flows in your veins, and that the same spirit of faith which sanctified him should be the mainspring of your heart. $\mathrm{He}$ watches you from above, where he prays for you, and hopes that one day you will dwell with him in God. Unite your desires with his. Conserva, fli mi, pracepta patris tui." x

× Correspondence, vol. i. p. 127. 
Unable for the present to see his beloved "petit Duc," or to communicate save at' rare intervals with him, Fénelon accepted this trial, like all others, with calmness-very far removed from indifference-and continued simply to devote himself to the duties and responsibilities of his diocese, which he worked with the power of a man of vast capacity, and the simple industry of a humble priest. Situated as he was, on the very borderland of France and Flanders, surrounded with hostile armies and belligerents of all nations, Fénelon's position was one requiring peculiar tact and discretion; and the surest proof that he exercised both is to be found in the fact that from first to last he won the respect and veneration of friend and foe. Prince Eugene, commanding the allied armies in the Low Countries, never failed to testify this by his conduct. Military honours were continually offered to Fénelon; and where justice or mercy required of him to enter any protest, or ask any seeming favour at the hands of the allies who were opposing his country, Fénelon's voice was always respectfully heard, and his demands granted. His diocesan flock, as a rule, were attached to him, and more or less perceptive of his noble nature; as he says in an early letter to de Beauvilliers, he set to work among them gently and tenderly, and he thought they liked him because they found him to 
be equable, quiet, disinterested, and free from pride. His greatest satisfaction seemed to lie in the consciousness that his people loved and trusted him; of his own immense power of fascinating rich and poor he seems-as probably all who possess such a power of necessity are-to have been unconscious.

When the worldly Saint Simon says of Fénelon that no man ever lived who so possessed "la passion de plaire," whether master or $\operatorname{man}_{\mathrm{s}}{ }^{1}$ he very likely speaks the truth in one sense, for probably few ever lived whose heart more abounded in love for all men, and in the consequent burning desire to pour out love and kindness upon them. Had the desire to please arisen from a worldly motive, as Saint Simon naturally supposes, (how could he be expected to see beyond the horizon of this world's good things?) Fénelon's conduct from his earliest to his latest days would certainly have been very different to what it was; and moreover, judging by ordinary experience, it is not probable that in such case Saint Simon could have added, as he does, that as no man ever so passionately desired to please, so no man ever so perfectly succeeded.

Cambrai was at that time a very central point, and a great thoroughfare, and nothing could surpass the courtesy, the charm, the discrimination, with which 
he received all comers, says Saint Simon. He never sought any one (this critical courtier goes on to remark, with a naïveté which contradicts his foregone conclusions), and at first people were shy of one known to be in ill-odour at Court; but by degrees his exceeding attractiveness drew the bolder few, and under their covert the multitude soon ventured to approach. Every one was glad to find an excuse for passing through Cambrai, until at last the whole world thronged it. The Duc de Bourgogne's unalterable affection for his Preceptor was so well known, that as time went on the self-interested part of that world believed it would prove no unwise game to cultivate the person dearest to the heir-apparent; but even Saint Simon could perceive the deeper lines of Fénelon's power to win love.

The quantity of people to whom he afforded a hearty hospitality, the number of passers-by he received cordially, the devoted care he bestowed upon the sick and wounded who were frequently brought to Cambrai-this it was, says Saint Simon, that won the heart of all the troops. The Archbishop's personal attention was given to the hospitals and to the humblest sufferers, while his palace was crowded with invalided officers, ${ }^{x}$ who frequently

I After the battle of Malplaquet, Fénelon even turned his Seminary temporarily out in order to make room for the wounded. 
remained his guests for months together, until their health was entirely re-established-precious months, in which he watched for their souls "with that knowledge of the world which enabled him to adapt himself to them, and which led multitudes to seek him out, never refusing his ministrations to the humblest of hospital subjects who sought them, and following up their needs as though he had no other claims upon him. Nor was he less active with respect to the bodily relief of all such. Bouillons, delicacies and alleviations of all kinds, ${ }^{x}$ not unfrequently the needful medical remedies themselves, were largely sent forth from the palace, and all this, in spite of the large scale, with a method and care that everything should be the best of its kind which scarcely is conceivable. He used to preside over the most important medical consultations, and in truth the degree to which the Archbishop became the idol of the armies, ${ }^{2}$ and in which his name was re-echoed far and wide, to the very core of Paris itself, can scarcely be expressed. His alms, his constantly-repeated episcopal visitations,

I "Les consolations des dégoûts," implying that " something to take after my nasty medicine," is no mere modern child's requirement.

${ }^{2} \mathrm{He}$ would often stop and enter into conversation with the private soldiers of the garrison at Cambrai, one of his personal attendants says, with the view of making some impression for good on them.-Correspondence, vol. xi. p. 176 . 
by means of which he thoroughly knew every corner of his diocese for himself ; the wisdom and gentleness of his government, his frequent preaching in towns and villages, his easy access, his consideration for the poor, his courtesy to all, the natural grace which enhanced the charm of whatever he did or said, made him perfectly adored by the people, and no less so by his clergy, whom he called sons and brothers, and treated them as such. Amid all this eager and universal desire to please," Saint Simon goes on to say, still unable to look beyond the lower motive, "there was nothing mean or ordinary, affected or undue; he always took precisely the right attitude towards each one; perfectly accessible himself, prompt and disinterested, he contrived to animate all who acted under him in that large diocese with a like mind, so that no one ever met with injustice or injury. Everything about and around him was in the most perfect order. His mornings were devoted to diocesan business. By reason of his powerful talent and penetration, combined with constant residence and daily attention to whatever claimed his eye, this was a comparatively short and easy task. That ended, he received all who sought him, then said Mass ${ }^{2}$ in his chapel. That done, he dined or breakfasted with his guests, who were always × "Et il y était prompt," adds the Marquis. 
numerous, eating but little himself, yet lingering at table for the sake of others, while charming them by the ease, the variety, the naturel, the cheerfulness of his conversation, without ever dropping into anything unsuitable to the dignity of a Bishop or a grand seigneur. He did not remain with his guests on leaving the table; they were accustomed to live in his house in perfect freedom both on his side and theirs. The Archbishop used to retire to his study, and work there for some hours, which were lengthened if the weather was bad or he had no external duties to perform. On leaving his study, he would go to pay needful visits or take a country walk, which latter was his favourite pastime, and one he willingly extended. If there were no visitor or distinguished person who claimed to be his companion in this walk, he used to take some official or other ecclesiastic, and discuss diocesan matters, or various religious and intellectual topics, amid which most delightful episodes would occur. He spent the evenings with whoever was in his house, supping with the military or other great people who might arrive, his table being served as in the morning. He himself eat even less than at dinner, and he always went to bed before midnight. While his table was always abundant and refined, and everything about him was consistent with the position of a grand seigneur, there was notwithstanding nothing 
but what was thoroughly episcopal and in conformity with the most precise rule, although tempered with a seemly and delightful ease. He himself was an everperfect example of all this, but one which it was difficult to follow. In everything he was a true Bishop, in everything a grand seigneur, in everything, too, the author of Télémaque. Never one word referring to the Court or politics with which it was possible to find fault, or which savoured in the least of flattery, regret, or servility; never anything whatsoever which could for one moment suggest the thought of what he had been or might yet be. Amid so much party strife the most perfect order existed in his domestic matters and in his diocese, but that free from all petty triviality or pedantry, and without any one of any rank being molested on doctrinal matters." $\mathrm{x}$

It must be confessed that such a description, given by one so little in harmony with Fénelon's real nature, conveys a strong impression of his power to win hearts. We have another, and more minutely-detailed, account of the Archbishop at home from that most amusing, if small-minded, chronicler, the Abbé Le-Dieu, Bossuet's secretary, and Canon of Meaux. His Journals are the most wonderful compound of really interesting matter and the veriest trivial details of his own

× Ménoires, vol. xxii. p. 379. 
ailments and physics, his meals, his petty quarrels with his Chapter and with the Bossuet family, and the like. Amid all this jumble we come upon a very interesting episode in September I $_{704}{ }^{\mathrm{x}}$ when the Abbé determined to pay a visit to the Archbishop of Cambrai, who, he says, had often invited him, knowing him to be a native of Peronne hard by. He had discussed the proposed visit with Mme. de Maisonfort, who had never ceased to lament her enforced separation from Fénelon; and she requested Le-Dieu to be the bearer of a letter to her former Director-a trust he the more readily accepted, as he tells us, because it afforded him an easy entrée to the Archbishop. We have the most minute details as to the heavy rain which made the Abbés journey uncomfortable, until he finally attained the Lion Inn, on the Place at Cambrai, September 15 $_{5}$ 1704. To his disappointment he found Fénelon absent on a visitation in Flanders, but the next morning an express announced the Archbishop's return that day to dinner. He accordingly arrived at noon, and Le-Dieu took care to be waiting in the first large salle at the top of the palace staircase. Fénelon's nephew, the Abbé de Beaumont, who never left him, and two other gentlemen from Paris, who frequently visited him (M. de l'Echelle and M. Lefèvre), were in

I Mémoires et Journal, vol. iii. p. 154 . 
the Archbishop's carriage; and he was met by his Grand Vicaire de Chanterac (afterwards Archbishop of Brabant), his nephews, the young de Fénelons, and others of his household and friends. "I was by the fireplace in the large billiard-room, and as soon as he entered I approached him with profound respect. At first his manner seemed to me cold and reserved, though gentle and courteous, inviting me to come in with kindness, but without empressement. I said, in a modest but audible voice, 'I profit, Monseigneur, by the permission it has pleased your Grandeur to give me to pay my respects to you when it lay in my power ;' and then I added, in a whisper, that I had brought him tidings and letters from Mme. de Maisonfort."

Thanks to the old Canon's love of minutiæ, we learn the precise style of Fénelon's dress. He wore "long violet garments, cassock and simarre with cords, buttons, and button-holes of crimson scarlet (écarlate cramoisi). I saw no golden tassels or fringes to his cincture, and he had nothing on his hat but a plain green silk cord; white gloves, and neither cane nor cloak. I gave him the packet of letters as soon

s The Abbé Galet says that Fénelon's wardrobe was always a very scanty one, and he would use none save the simplest materials. He adhered to the same rule even with respect to his ecclesiastical vestments; neither would he have lace or other costly trimmings (as was the custom) on his albs or rochets. One 
as we entered his room, and without opening it he made me sit down above him, and in a fauteuil corresponding to his own, not permitting me to take a humbler seat, and obliging me to put on my hat."

After an unimportant conversation, recorded $d$ la Boswell, dinner was announced; the Archbishop rose, and invited Le-Dieu to his table. We will profit by the old Canon's detail to get an almost photographic description of Fénelon's domestic life.

"All the guests awaited him in the dining-room. .... One washed one's hands sans façon, and as among friends. ${ }^{x}$ The Prelate said grace, and took the chief place, of course; M. l'Abbé de Chanterac sat on his left hand; every one else took their place as it

day he showed the Abbé a splendid pastoral cross, set with emeralds, which the Elector of Cologne had given him, and M. Galet observed that he hoped the Archbishop would wear it, as it was so infinitely handsomer than that he generally wore. But Fénelon answered, with a smile, that he had accepted the gift with a resolution in his own mind never to wear it. "Would the holy bishops who are our examples have worn such? Not they. God forbid that the Cross, which is meant to be a memorial to me of the poverty and nakedness of Jesus Christ, should be insulted and despised by worldly pomp even on my breast."Correspondence, vol. xi. p. 164.

I Does the Abbé mean that in the Palace at Cambrai there was a public tap of water, and a long towel hung from the ceiling, with a view to general ablutions, as one still sometimes may see in "commercial" hotels in France? 
might happen after they had washed. I took a chance place, and my soup was served to me. But the seat on the Prelate's right hand was empty, and he signed to me to take it. I thanked him, but pointed out that I was already seated and served. $\mathrm{He}$ pressed me gently and civilly, 'Come, this is your place.' So I went without further resistance, and they brought my soup after me.

"We were fourteen at table, and in the evening sixteen; and as I saw no tables in the dining-room but bigger ones, suited to eighteen, twenty, or twentyfour couverts, I concluded this to be the ordinary table; and indeed there was no one present but his own attendants and familiar friends, who never leave him....

"The table was served magnificently and delicately: several soups, good beef and good mutton, all sorts of entrées and ragoûts, a handsome róti, partridges and all kinds of other game variously dressed; magnificent fruit, exquisite peaches and grapes, albeit in Flanders, the best kinds of pears, and all manner of compotes; good red wine, no beer; the linen was clean, the bread excellent, a great quantity of plate, very solid and d la mode. There were a great many servants in livery, who waited well and neatly, without noise, and carefully. I saw no pages; the Prelate was served by a footman. I liked the looks of the maître d'hôtel, 
who seemed to be duly respected and of weight in the household. ${ }^{x}$

"The Archbishop took the trouble to help me with his own hands to everything that was choicest on the table, and every time I thanked him with the greatest respect, hat in hand, as each time he too did not fail to take off his hat to me; and he also did me the honour to drink my health-all very seriously, but with a very easy, courteous manner. The conversation was very easy, pleasant, and even mirthful; the Prelate took his part, and left every one full scope. I noticed that his chaplains, secretaries, andécuyers talked just like the rest, quite freely, though nobody presumed to chaff

× The Abbé Galet mentions Fénelon's peculiar consideration for his servants. He used to speak in strong language of the want of generosity people show who treat their attendants roughly or unkindly. "Why should one add to the trials of their position by want of civility, poor people!" he used to say. "Nevertheless, sometimes I scold out of natural quickness; but the next moment I am sorry for it, and cannot rest till I have made up for my sharpness by some kind of apology, which soothes my poor servant at the expense of my own self-love." Sometimes his friends would tell the Archbishop that he spoilt his servants, and that his over-indulgence made them careless. "I grant it," he would say. "I know I am not as well served as I ought to be; mais que voulez-vous! We are all men-that is to say, full of faults-and so we must be ready to forgive one another a good many things; I would rather err on the side of over-indulgence than of too great severity, 'ira viri justitiam Dei non operatur.' " -Correspondence, vol. xi. p. 158. 
or satirise. ${ }^{x}$ The young nephews did not talk. The Abbé de Beaumont kept up a conversation turning chiefly upon M. de Cambrai's journey; but this gentleman was very polite, and I saw nothing of the haughty, contemptuous manners which I have so often encountered elsewhere;-indeed, I met with far more modesty and civility than usual, both from the master himself and his nephews and others.

"These tables for sixteen, eighteen, and twenty persons were very noticeable to me, as indicating that this Prelate always does his clergy the honour of receiving them at his table for dinner and supper, which is more than the Archbishop of Rheims does: ... he has always a separate table for his clergy and secretaries. M. de Noailles, when at Châlons, did the same-still more when he became Archbishop of Paris, and most of all since he was made a Cardinal, so that it is a sign of great modesty in M. de Cambrai, with his titles of Duke and Prince of the Empire, and all his wealth, to gather his priests at his own table. The Prelate eat very little, and only the lightest and plainest food: at supper, for instance, he only took a few spoonfuls of ceufs au lait, and he only drank two or three glasses of a very weak white wine. I never saw such temperate feeding. ${ }^{2}$ In conse-

Railler, ni épiloguer.

2 " Un régime sévère qu'on se fait une loi étroite de garder, et 
quence, he is extremely thin, his complexion clear, but colourless; and he said himself, "No one can be thinner than I am.' But he is in good health, and did not seem tired or weary after his three weeks' journey. . . .

"After dinner everybody went to the Archbishop's great bedroom, where again this Prelate insisted on giving me a place of honour; so I went to the foot of the bed, against the wall, by $M$. de l'Echelle, leaving the back of the room for those who followed. The Prelate sat by the fireplace, near the middle of the room, a little table beside him, at which he wrote as occasion required, his secretaries and chaplains (merely in cassocks) taking his orders for letters dimissory, and other papers which they brought to him to sign, as he was not going to hold an ordination himself this time, there being only some monks who were to be sent up for Orders.

qu'on observe journellement, sans s'en écarter le moins du monde, devient, par cette continuité, un assujettissement qui vaut lui seui une bonne pénitence: $j$ 'en atteste l'expérience. On voit toujours en effet tous les jours qu'on craint moins de souffrir et d'être malade, que d'être toujours aux prises avec soi-même pour combattre ses goûts; preuve certain que cette contrainte est très mortifiante. M. de Cambrai pratiquoit donc un régime éton. nant, certes, soit pour l'uniformité invariable de la nourriture qu'il prenoit, soit pour la très petite quantité dont il en usoit. Je ne lis point ce que Jésus Christ dit de Saint Jean Baptiste, que je ne me sente porté à en faire l'application à votre saint Prélat, "Venit neque rnanducans, neque bibens.' "-Correspondence, vol. xi. p. I6r. 
"After a while the Dean was announced: he is M. de Franqueville, a Doctor of Theology, of a noble family in Flanders, and a man greatly esteemed in Cambrai and in the Chapter. The Archbishop saluted him with the title of $M$. notre maittre, and so did the Abbé de Beaumont. He was treated with every sign of familiarity and friendship. The Doctor placed himself in the most dignified seat in the room: he talked a great deal, chiefly about news from the Court of Brussels and the like, and showed by his conversation, by his hurried manner, his loud voice, and frequent gesticulations, signs of a flighty character. . . . The Prelate received him with an affable tone of welcome, and a more open, bright countenance than any one else. But no one except the Dean came, which seemed to me very extraordinary on the return of this great Prelate. Then coffee was brought, and served to everybody; M. de Cambrai had the politeness to have mine served with a clean napkin! . . . Between two and three o'clock M. de Cambrai went to see the Comte de Montbrun, the Governor, ... . and appointed me to an interview after his return. . . ."

The old gentleman's curiosity was always insati-. able, and as soon as the Archbishop went away, he profited by the opportunity to investigate all the rooms and their arrangement minutely, although, as he tells us, Fénelon had already shown him all his 
apartment. This palace, unfortunately, was destroyed at the Revolution, and consequently Le-Dieu's precise description of the locality is scarcely worth repeating. It seems to have been spacious; a considerable part had been rebuilt by Fénelon himself since the fire already alluded to. The old chapel remained, and corridors communicating between that and the living rooms afforded space for walking up and down, as Fénelon was apt to do when engaged in conversation. The salle $d u$ dais, or grand reception-room, is of course minutely described, with its crimson velvet dais (beneath which the Archiepiscopal Cross was placed), its tapestried hangings representing scenes from the Book of Genesis, its red velvet fauteuils, curtains, and portieres-down to their gold fringes and galloons. So, too, the state bedchamber, and its crimson damask furniture, which we may be excused for not cataloguing. The most interesting objects were portraits by Rigaud (or in his style) of the King, the Dauphin, the Duc de Bourgogne, and his brother the young King of Spain; besides which there were several pictures of religious subjects in the ruelle, .which Le-Dieu does not describe beyond pronouncing them to be by good artists. This, however, was only used as a sitting-room. Fénelon himself slept in a little room ${ }^{x}$ adjoining, furnished merely with some × The Abbé Galet says, that, feeling obliged to have his public 
grey woollen material, and unadorned save by a few good engravings, causing the Canon of Meaux to expatiate upon the Archbishop's lowliness, and how everything that concerned his office was splendid, but all that concerned himself only as modest as possible. In spite of the fire which had destroyed so many of his books, Fénelon appears to have had a large library at this time, though Le-Dieu dwells upon the black leather chairs and tables, and the well waxed and polished floors, rather than upon literary details. The garden was merely a square parterre, enclosed with alleys of trees. Fénelon told Le-Dieu that he sometimes thought of turning various yards and spaces about into garden, but that he could not afford it now, and preferred first to rebuild all that had been burnt. Le-Dieu seems to have been much struck by the carriages he saw in the cour, and by the fact that such ample consideration was shown in all respects for the convenience of the Archbishop's suite and officials, who, he says, were never sent on journeys save under comfortable circumstances. ${ }^{x}$

rooms furnished with a certain degree of state, according to the custom of the time, out of respect to his position and office in the Church, Fénelon's compensation (disliking it as he did) was to inhabit "a little cell at one side, where the furniture was the plainest serge. C'était là son habitation délicieuse, qu'il préféroit à la magnificence des plus superbes palais."-Corresfondence, vol. xi. p. 165 .

₹ “. . Tout est grand et commode en cette maison, et l'on 
About four o'clock, having paid his visit to the Governor, Fénelon gave Le-Dieu the promised interview; nor does the vain old Canon omit to record again how honourably he was placed by the Archbishop, ${ }^{1}$ or how, on an interruption obliging him to dismiss his guest, the Prelate held open the door for him, and said courteously, "Vous êtes le maître," so that he might not feel obliged to wait. So Le-Dieu went down to the garden and joined the Abbé de Beaumont, to whom he seems to have imparted a large amount of information concerning Bossuet and other matters, (the dear old gentleman always gives one the impression of a vast vessel of heterogeneous small-talk, only needing the tap turning to flow on indefinitely!) until at length he was recalled to Fénelon's presence. Conversation turned, he says, on the piety, spirituality, and faithfulness to duty of holy souls-a line in which it occurs to one that the Archbishop must have had all the personal appreciation of their subject, though doubtless the good Canon could let flow his banalites on this as on all other topics. Fénelon naturally avoided any discussion which touched Bossuet, a reserve which Le-Dieu n'y fait pas faire de voyages aux ecclésiastigues qu'à leurs points et aises ; ce qui fait aussi beaucoup d'honneur au maître et le fait aimer et respecter comme il l'est partout."

I "Il me fit encore asseoir au-dessus de lui avec la même distnction que le matin." 
seems scarcely to have understood. He says that, when speaking of Mme. de Maisonfort, the Archbishop told him to ask any questions he pleased, and that he would answer as simply as a child-a famous opportunity for pumping the great man about Quietism, Le-Dieu remarks, but he wisely abstained. Fénelon seems to have gratified the former secretary by talking with him about various matters of Church discipline, about his Seminary, and diocesan work.

At supper Le-Dieu found himself treated with a like consideration, and afterwards Fénelon questioned him with deep interest concerning Bossuet's deathbed, apparently confining himself to spiritual details, for Le-Dieu says he made no allusion to the Bishop's will, or any private matters, still less to the matter of Quietism. Rather before ten o'clock the Archbishop inquired if the household were assembled, and saying, "Let us pray," the whole family joined in evening prayers in the before-mentioned large bedroom, a chaplain saying them. Prayers ended, Fénelon ordered the Canon to be conducted to his sleeping apartment with bougies and a flambeau de poing, apologising because the said apartment was on the other side of the court, and accompanying him to the door of the salle du dais, where he took leave of the gratified ecclesiastic, who went the next day to Beaumetz, in a storm of wind and rain, much com- 
forted by the courteous reception on which he could dilate at length to his relations. But, like most other chroniclers of petty and often egotistic details, LeDieu lets in a bright light upon the picture one loves to contemplate of that holy man, devoting himself to his daily duties calmly, and without longings after the more brilliant scenes he had left for ever.

One of Fénelon's great interests at Cambrai was his Seminary, which, educated as he had been at Saint Sulpice, he naturally wished to mould upon that model as far as possible. There is an interesting correspondence remaining between him and his former Superior Tronson concerning it, as also letters from Tronson to de Chanterac, Sabatier, etc., which show the high value and respect he always felt for his former disciple, and his willingness to help him. ${ }^{\mathrm{x}}$

"Mgr. de Cambrai is the prelate of all prelates in France," Tronson writes (Nov. I I, 1695) to de Chanterac, "whom we prize the most, and to whom we would most gladly supply workers for his Seminary;" and a month later he writes to Fénelon himself, that nothing save the lack of suitable subjects has hindered such being sent to Cambrai. How thoroughly the Archbishop worked the thing himself may be gathered from a letter to Tronson (Jan. 7, I697), in which he says, "Send me teachers possessed

×Correspondence, vol. v. p. 198. 
of straightforward sense, easy of access, and with a hearty good-will, and I answer for their success. I will myself watch over everything. I will lead them through the beginning, and give them sanction and authority. I will see to and uphold all. M. de Chanterac, who is equally wise in action and firm in dogma, will help us. No one shall have any fault to find. What our people do not know at first they will have leisure to learn. I shall live like a brother among them. I do not ask for refinement or dazzling talents; I only want common sense, and a will thoroughly given to God. If you can give me anything beyond that, it will be so much more than I expect. Think of my attachment to your house, and you will feel that you ought to make an effort to help me. I feel sure they will care for me when we have lived a little while together. They will not find me, please God, either fastidious, or jealous, or mistrustful, or capricious, or obstinate. This I hope of God's Goodness, not of my own strength. . . . There is an immense work to do here, and workers in whom I can trust are lacking."

Saint Sulpice had not been yet able to provide Fénelon with the teachers he desired when the storm of disgrace burst over him, and with characteristic delicacy and consideration he at once thought no more of himself and his own needs, but of the - Correspondence, vol. v. p. 2 IO. 
possibility (only too great after the way all connected with him were treated) that the Society he loved might suffer through him, and consequently suspended all negotiations with Saint Sulpice, just in the same spirit as that which made him quit Paris without taking leave of his dear friend Tronson. ${ }^{x}$ It was not till after that friend was dead, and quite at the close of his own career, that Fénelon effected his desire, and saw his Seminary in the hands of the Saint Sulpiciens. Meanwhile his unfailing helper, the Abbé de Chanterac, took the lead in its work, and the Archbishop amply kept his promise of working it himself. $\mathrm{He}$ was continually mixing both with the teachers and the taught, and made a point of personally knowing all the men whom he ordained, winning their love and confidence as a father before the time when he had to sit in judgment upon their qualifications for Holy Orders. $\mathrm{He}$ frequently gave instructions and retreats in the College, and regularly once a week held what he called a conference there on some selected subject, encouraging the students to discuss it with him, and to ask questions, or state the doubts which might be suggested to them. This habit made him a more competent judge of their religious and mental powers than even the regular examinations, which the Archbishop invariably superintended himself, maintaining 
a certain amount of ceremonial on these occasions which he considered due to the dignity of the circumstances, but which was not alarming or discouraging to the Ordinands, who were accustomed to his kindly and paternal manipulations. It was said in the diocese-so invariable was the Archbishop's practice with respect to these-that there was no priest within its limits, ordained by him, whom he had not personally examined five times. Neither was his care for his Seminary confined to its spiritual and intellectual needs. Writing to his nephew, the Abbé de Beaumont, Nov. 7, 17ro, concerning his financial affairs, Fénelon mentions, in addition to his heavy household expenses, the burnt down buildings that were still but partly replaced, his soldier nephew to be helped in the service, great-nephews to be educated, etc., etc.; while in addition to all these there was his Seminary to maintain, nearly all the seminarists to feed, and bons sujets to be supported in Paris, ${ }^{\mathbf{x}}$ i.e. men who went up there for one reason or another from the Cambrai College at the Archbishop's expense.

Fénelon's opinions as to the interior working of

x Correspondence, vol. ii. p. $\mathrm{x} 3 \mathrm{o}$. When men who were likely to prove good priests were too poor to defray their own expenses, Fénelon constantly undertook these himself, "in order," as he said, " to insure capable and edifying clergy for the diocese."Correspondence, vol. xi. p. 184. 
such an institution may be gathered from his correspondence. "I often pray," he says, writing to M. Leschassier, Superior of Saint Sulpice in 1706, when sending one of his clergy to his care, "that the primitive spirit of simplicity and separation from the world's ways may be preserved in Saint Sulpice. If a taste for brilliancy and dashing talent slips in, gradually the work done by M. Olier and M. Tronson would cease to exist." I While attending himself to all the affairs of diocese and Cathedral, Fénelon never sought arbitrary power; and de Ramsai, who lived so long in his house, says that he never did anything of importance save in concert with his VicarsGeneral and the "Chanoines de son conseil," who met him for business regularly twice a week.

The religious houses of the diocese also received the kindliest, most paternal care from its Archbishop, who was ever ready to give his attention and labour to the humblest Community of his flock, as may be illustrated by the following extracts from a paper of Counsels drawn up by him for the benefit of some Religious after a visitation, in which it had appeared to Fénelon that they were deteriorating in regularity of life :-

"... The Superior is mother of all ; she should esteem all the Religious as her children, with equal 
affection, as is needful in order to preserve peace and union among the Sisters. They, on their part, should respect and obey their Superior, ever bearing in mind their vows and the Example of Jesus Christ.

"It is important to avoid special friendships, whence spring cabals and lack of harmony. The Religious of a Community should all love each other as sisters, serving the same Master, living under the same rules, aiming to win the same inheritance. If any one feels it a duty, either to the Rule or out of charity, to make a complaint against another, the Superior should be most discreet in dealing with such complaint. . . ."

He goes on thus through a variety of subjects, dwelling at length on the importance of ascertaining that those adnitted into religious houses have a true vocation and a "real religious mind."

The unremitting labours which Fénelon steadily persevered in necessarily involved a regular life of industry. $\mathrm{He}$, like Bossuet, gave but a short time to sleep, ${ }^{2}$ and his working hours began early, so that he had already done nearly a day's work before saying Mass. $^{3}$ His habit was to say this in his own chapel,

I Correspondence, vol. v. p. 243.

2 "Il dormoit très-peu, nulle partie de sa vie exempte de mortification; imitation aussi sincère que continuelle du grand apôtre; semper mortificationem Jesu in corpore nostro circumferenter."- $\Lambda$ BвE GALET.

3 The Abbé Galet says that Fénelon spent several hours in 
except on Saturdays, when he said it in the Cathedral, remaining there to hear the confessions of penitents of any and every class who chose to present themselves. $\mathrm{He}$ not unfrequently preached in the Cathedral, but seems to have preferred the town churches, in some one of which he always preached the I.ent Station. But few comparatively of his sermons remain to us in full written form; an Epiphany sermon, preached at the Missions Étrangères, in 1685 , a few Saints'-day sermons, one for the profession of a Religious, a great Discours preached on the occasion of the Elector of Cologne's consecration (May I 707), and a few Entretiens, are all we find, ${ }^{x}$ together with a certain number of "plans," which seem to have been his more usual method of preparing his sermons. These are most carefully worked out, usually occupying three or four pages of print, and leaving all but the skeleton to be filled up in preaching. ${ }^{2}$

Fénelon probably never was an orator, certainly

prayer before saying Mass :- "Il étoit homme de prière; je m'exprime mal, consommé dans l'oraison."-Correspondence, vol. xi. p. 167.

${ }^{x}$ De Ramsai says, in his Life of Fénelon, that he did not write his sermons. "Tous ses sermons étoient faits de l'abondance de son cœur. Il ne les écrivoit point. . . . Comme Moïse l'ami de Dieu, il alloit sur la montagne sainte, et revenoit ensuite vers le peuple lui communiquer ce qu'il avoit apris dans cet entretien ineffable."-Histoire, p. 93.

2 Euvres, vol. vii. 
not in the sense in which Bossuet was one. His preaching seems rather to have been, like his letters, characterised by its exceeding beauty and spirituality of thought, and easy, simple style, than by any masterful power of language, calculated to carry away his hearers. "To think like Pascal, to write like Bossuet, and speak like Fénelon," has been desiderated as the perfection of human gifts. ${ }^{x}$ His own ideas on the subject may be studied in his Dialogices sur l'Eloquence en général, et sur celle de la Chaire en particulier," written in his early days, and only published after his death, and in a letter written to the Académie Française on L'Eloquence, la Poésie, etc. 3 Not to quote at length from these writings, one passage we must give, as forcibly illustrating at once Fénelon's classical purity of taste, and his intense and deep-down love for and knowledge of Holy Scripture.

"Let us return to the eloquence of Holy Scripture," one of the interlocutors in the dialogue says.- "To appreciate that," replies the person who is speaking Fénelon's mind, "nothing is more helpful than a taste for ancient simplicity; and, above all, the study of the ancient classic Grecians will promote such appreciation. I say advisedly the ancient, for those

I Marquis de Vauvenarques. $\quad$ E Euvres, vol. x. p. I67.

3 Ibid. p. 309. 
Greek writers, whom the Romans called Graculi, and whom they so justifiably despised, were utterly degenerate. But, as I was saying yesterday, you should study Homer, Plato, Xenophon, and other early writers, and then you will no longer marvel at Holy Scripture. You find almost the same customs, the same narratives, the same pictures of great deeds, the same action. What difference you find there is absolutely in favour of Holy Scripture, which surpasses them all infinitely in simplicity, life, and force. Not even Homer ever approached the sublimity of the songs of Moses; especially the last, which was to be learnt by all the children of Israel. No Latin or Greek ode ever attained to the grandeur of the Psalms. For instance, that one which begins, "The Lord, even the Most Mighty God hath spoken, and called the world' (Ps. l. E.V.), surpasses all power of human imagination. Neither Homer nor any other poet has ever equalled Isaiah in describing the Majesty of God, in Whose Eyes earthly kingdoms are but as a grain of dust, Who spreadeth out the heavens as a curtain (Isa. xl.) At one moment the prophet speaks with all the grace and tenderness of a eclogue in his softly-smiling picture of peace, and the next he lifts himself up till all else is left far below. Again, what is there in classical antiquity which can compare with plaintive Jeremiah bewailing his nation's woes; or Nahum in 
the spirit beholding afar off the fall of stately Nineveh before countless hosts? One seems to behold those hosts, to hear the clash of arms and chariots; the living description kindles imagination; it leaves even Homer far behind. Or again, study Daniel bearing the message of God's vengeance ready to fall on Belshazzar, and see if in the sublimest masterpieces of antiquity you can find anything comparable. Moreover, in Holy Scripture everything is sustained, everything keeps up its characteristic tone, whether it be history, legal detail, description, passion, mystery, or instruction. And there is as great a difference between the classical poets and the prophets as between true and fictitious enthusiasm. The prophets, who were really inspired, consciously deliver that which is Divine; the others, while striving to lift themselves up beyond themselves, continually betray the mere human element. Only in the Second Book of the Maccabees, in the Book of Wisdom, chiefly towards the end, and in the beginning of Ecclesi. asticus, do you find anything resembling the inflated style which the already deteriorated Greeks had imported into the East, where their language had taken root together with their rule." And answering the question whether, if all this be true of the Old Testament, at least our Lord Himself did not speak with the utmost simplicity, Fénelon says:- 
"That simplicity is perfectly classical, it is like to that both of Moses and the Prophets, whose words our Lord frequently employs; but simple and familiar as it may be, it is sublime and full of imagery. It would be easy to take up the Bible and prove minutely that we have no modern preacher whose most studied discourses so abounded in illustration as did the popular teaching of Jesus Christ, and that without including $\mathrm{His}$ sermons recorded by $\mathrm{S}$. John, where every word is consciously Divine; I am speaking rather of His more familiar teaching as recorded by the other Evangelists. Even so with the Apostles, with this difference, that Jesus Christ, complete Master of His doctrine, handles it calmly ; $\mathrm{He}$ says what $\mathrm{He}$ pleases without effort, $\mathrm{He}$ speaks of the Kingdom and Eternal Glory as of His Father's House. The grandeur which overwhelms us is natural to $\mathrm{Him}$; it is His Home, and He speaks of 'that which He has seen,' as He Himself tells us. The Apostles, on the contrary, are bowed down beneath the weight of the truths revealed to them; they cannot give utterance to the conception of their hearts, words fail them. Hence the transpositions, confused expressions, and arrangements we meet with. All these inequalities in S. Paul and the other Apostles prove that their minds were overruled by the Spirit of God; and in spite of sundry little ruggednesses of style, all we read 
is noble, living, pathetic. As to the Apocalypse, we find the same magnificence and enthusiasm in that as in the prophets: the very expressions are often identical, and sometimes this serves to the clearer understanding of both. So you see eloquence exists alike in the Old and New Testaments."

Fénelon goes on to urge the importance of making sermons a channel of expounding Holy Scripture, not merely of preaching morality, or the best and ablest line of reasoning.

While carrying on all this laborious and stedfast pastoral work, Fénelon likewise found time for an enormous correspondence, sometimes to a considerable extent concerning ecclesiastical affairs, partly literary, but in the main spiritual. Perhaps his spiritual letters are the most perfect things of their kind anywhere to be found, and multitudes who never have read and never will read any of his published works have found infinite solace and benefit in the wise, tender, thoughtful letters which poured from his ready pen on behalf of all who sought comfort and guidance from one of the most sympathising and ablest friends and

I Euvres, vol. x. p. 27r. His devotion to Holy Scripture, and to a prayerful study of it, was a marked feature in Fénelon's life. "Read it faithfully," he used to say, "standing up, with uncovered head, with avidity : we need to hunger and thirst after righteousness, and to feed with hearty appetite on the Bread of God's Word."-Correspondence, vol. xi. p. 169. 
directors that ever lived. These spiritual letters are much too numerous to find place in a sketch like this, and will accompany it in a separate form; but there are also many letters which, while not precisely to be classed among spiritual, properly so called, are most valuable and beautiful in themselves, and fill up the history of those years spent at Cambrai in exile from the scenes of which Fénelon would have been the noblest ornament, had not the petty-mindedness of a so-called Great Monarch banished him from them.

In November 1699, we find him writing to that never-failing friend the Duc de Beauvilliers :-

"I am quietly settled here, and in a position, if it so please God, to do some good. . . . If I can but get a good Seminary I shall be only too happy. I am sorry, dear Duke, to be separated from you, the dear Duchess, and a very few other friends. But for all else I rejoice in being far away; I sing my canticle of thanksgiving for deliverance, and nothing would cost me so much as to have to return.

"I love the Duc de Bourgogne dearly, in spite of his many great faults, and intreat you never to let your friendship for him slacken; let it be a faithful, unsparing friendship. You must travail painfully until Jesus Christ be formed in him. Bear with him without flattering him, admonish him without oppressing him, 
availing yourself of such opportunities as Providence may open to you, and being thoroughly faithful in all such; tell him necessary truths, but tell them briefly, lovingly, with tenderness and respect. It is providential that his heart does not lean towards those who would fain estrange him from you. For God's Sake, do not let him escape you; and if he should ever fall into any great fault, let him feel that your heart is open to him, as a haven in shipwreck. I only write to Paris through the most secure channels, and that to very few people-in fact, only to you, and the petite Duchesse, ${ }^{x}$ and the petit Abbé, and at long intervals to the Duc de Charost. Scarcely anybody writes to me. La petite Duchesse et le petit Abbé do not write to me by the post. . . . I pray God to give you His Wisdom and Strength, 'esto vir fortis, et præliare bella Domini.' And again I would apply to you the words of Holy Scripture: 'Quis tu, ut timeres ab homine mortali.' God will be with you, if you are continually with Him."

In July r 701 , the Chevalier d'Albert, one of the Duc de Chevreuse's sons, was killed at the head of his regiment, at Carpi on the Adige, and Fénelon writes

× This was Fénelon's pet name for the Duchesse de Beauvilliers. In his intimate correspondence she is frequently alluded to as the "P. D." only, while the Abbé de Langeron is often indicated by "le P. Ab."

2 Correspondence, vol. i. p. 79. 
to the bereaved parents-who had ever been such dear friends to him, and who now were sorrowing both for their loss and with natural anxiety as to the soul of their son-with the tenderness of a brother.

\section{"August r, r yor.}

"I have heard of your loss, dear Duke, with the deepest sorrow. God has sent it, and we must bear it silently; we can only pray for him we have lost. You know how much I loved him, and how keenly I felt whatever concerned him. I am sure that you will bear this cross calmly, and that from the first you have given up the dear child it has pleased God to take as a sacrifice to Him. But I feel anxious for the Duchess's tender heart ; for though I noways doubt her submission to God's Will, I know that the sorrow must wring her soul, and I pray our Lord to comfort her. The good things of this life are but poor consolation, and they almost always involve us in the danger of cleaving overmuch to them; but as to the sorrows of which life is so full they are trying indeed. Our whole path is sown and strewn with thorns; we are here below only to suffer, and to love Him Who proves us by suffering. All our most lawful attachments turn to crosses; God rends them in order to bind us more closely to Himself, and in so doing $\mathrm{He}$ tears asunder those ties of the heart to which 
external objects are bound. But we must always submit to God's Hand when He undertakes this painful operation.

"I can sympathise more than most people with the sorrows of your dear Duchess, who has always sympathised so much with mine. ... I would I could transport myself invisibly to your solitude. But I feel as if we were near, even now that God separates us, and in Him you are ever very close to my heart, and will be to the last breath I draw."

\section{"August 18, 1701.}

"I have just received your letter, dear Duke, and I think you will have received mine, which I wrote by the first secure opportunity after hearing of your loss. I feel that loss, and the sorrow which overwhelms you; but I have no fear for you, being sure that your heart will be filled with the peace which is always inseparable from a true love of God's Will. I only pity you because of the secret wound which seems to wither your heart. But suffering is the hidden life of souls while on earth, for it is only through death that the germ of the new life is raised up in us. All that seems to make the seed perish in the earth is really causing it to spring up and grow meet for the harvest.

"Still you must not dwell too much on distressing 
thoughts. The frailties of one so youthful, and thrown into a life of so much dissipation, are not so pernicious as the intellectual vices which are cloaked with refinement, and dressed up like virtues at a later age. God beholds the clay of which $\mathrm{He}$ has made us, and has pity on His poor children. Besides, if the torrent of example and passion had led the young man somewhat astray, we can still say, as the Church says in her prayers for the dying, ' $\mathrm{He}$ hath believed and hoped in Thee, O God.' A deeply-rooted faith and religious principle, lying hidden beneath passion and excitement, will wake up in a moment of extreme danger. The extremity of the moment disperses all illusions, tears away the veil, opens the eyes to eternity, and recalls many half-forgotten truths. The heart once taught to know Him and seek His Mercy turns by instinct to God at His faintest whisper in such a crisis. He needs neither time nor much speaking to make Himself heard and felt. $\mathrm{He}$ said but one word to Mary, and she answered but one word, ' Master.' That said all. He called His child by her name, and thereby she knew Him at once. His ineffable word is all-powerful; it creates a new heart and mind within the man. Weak men, who can only see the outside, want great preparations, fixed actions, well-framed resolutions; God needs but one instant, in which $\mathrm{He}$ does all, and sees what $\mathrm{He}$ does. 
"It would be fearful presumption to count upon such miracles of grace; but $\mathrm{He}$ Who forbids us to count upon them is pleased sometimes to perform them. You will find S. Augustine saying repeatedly that life itself is a grace, inasmuch as God prolongs it as an invitation to the last to us to be converted. Do not doubt it. He Who truly desires to save sinners waits for their salvation, and His waiting would be in vain if $\mathrm{He}$ refused the succour necessary for that salvation in the last hour of the final combat. "Wherefore, comfort one another with these words.' ' I pray the Spirit of consolation to soften your burden and the Duchess's. Every day I take you both in my heart to the altar, together with all your family, which will be dear to me while I live. Nor do I forget the poor child you have lost. I am ever yours in Him Who so greatly loves us, and Whom we all seek to love," etc. etc. ${ }^{2}$

The de Chevreuses hoped to visit Fénelon, and enjoy his sympathy and power to comfort viva voce, but an obligatory attendance on the King forced them to give up this consolation and to remain at Versailles.

Three years later another of their sons, the Duc de Montfort, was also killed in battle near Landau, and we find a letter from Fénelon to a younger

I Thess. iv. 18.

2 Correspondence, vol. i. p. 108. 
brother, who was greatly shocked at the sudden loss, amid his correspondence. After expressing the writer's own sorrow, he continues:- "This touching event has brought you into a very close realisation of the vanity and hollowness of the dream we call life. Men cleave closely to the world, but it does not cleave to them. Life, uncertain as it is to all, is doubly so to men of your profession; they cannot count on a day, however strong and healthy. Yet they are absorbed in the amusements of a life which is in ceaseless peril ; they rarely think of death, which they advance to meet half-way, as though it were not striding towards them already.

"Men are perpetually upheld by God's Hand, and yet they think not of Him, and use all His best gifts only to offend Him. They do not wish to die in His displeasure, but they will not live in His Love. They confess that they owe Him everything, but will give Him nothing, preferring the most contemptible pleasures to Him. Men would often be ashamed to utter the things which they allow to take precedence of Him in their hearts. They own the worthlessness of the world, yet they meanly make use of it ; they know the greatness and mercy of God, yet all they offer Him is an empty show. Such a state is as contrary to reason as to faith.

"You know the truth; you would fain follow it. 
You would shrink from dying as many men who are well spoken of are not afraid to live; but you are carried away by the torrent. You are dissatisfied with yourself, but you cannot make up your mind to do what alone will bring you peace. Why delay? All the evasions with which you flatter yourself are false. God asks everything, and everything is due to Him. You cannot admit of any half-measures, any delay. The least we can do for Him Who gives us all we have, and on Whom we depend wholly, is to give ourselves up to Him heartily. Would you lay down the law to God? Would you fix the limits of your own dependence? Would you say to Him, 'I feel you worthy of the sacrifice of this or that interest and pleasure, but I cannot make up my mind to sacrifice this other one to you?'

"Are you going to wait till your passions are worn out to sacrifice them? Do you mean to go on, while your worldly tastes wear themselves out, spending your life in ingratitude, in resisting the Holy Spirit, and despising the Goodness of God? Do you mean to run the risk of one of those terrible sudden deaths which sometimes overtake hardened sinners? It is not merely a question of abstaining from great sins; you must turn stedfastly towards what is good, follow it perseveringly, not lcok behind you, make up your mind to restrain yourself, foster your faith with solid 
reading, with heartfelt prayer, and aiming at recollection of God throughout the day.

"You must mistrust your own weakness, and still more the presumption without which mere weakness would humble you, and make you feel the need of prayer. You should fear and shun as far as possible, according to your position, all dangerous society. When we do not love that which is evil, we cling neither to its occasion, its appearance, nor its memories.

"You should strive to be fit to receive the Sacraments frequently with profit and comfort, in order to get rid of your languid, dissipated state. Men are disgusted and discouraged, till they are tempted to despair; yet they will not seek strength where alone it is to be found, nor draw consolation from the one true Source. Oh, how light-hearted you would be if you had broken all your bonds! How you would bless God for having saved you from yourself if this blow were struck! The operation is painful, but the health restored thereby would be your blessing. I pray the Lord to give you such courage : ask it often for yourself. In Him I am," etc. etc. ${ }^{x}$

Many letters of firm, manly, yet most tender counsel to this young man, as well as to others of a similar class, will be found more fittingly placed in the Spiritual Letters; but, indeed, most of Fénelon's - Correspondence, vol. i. p. 157. 
friendly letters are so mixed up with the element most natural to him of spiritual things, that it is sometimes difficult to classify them.

One young man, indeed, there was to whom his letters were written with the fervour and passionate affection of a parent, the Duc de Bourgogne, and no portrait of Fénelon can be exact which does not give this feature with some precision. Already certain letters, written in all the secresy that something evil, instead of the connsels of a saint, might have required, have been quoted. Early in the year I 702 the King gave the command of his army in Flanders to his grandson, who was to be in a sort of state tutelage under the Maréchal de Boufflers: such was the way formerly in which princes were taught the art of war. To reach Flanders the Duke must needs pass through Cambrai, and he naturally put strong pressure on his peremptory grandfather to be allowed to pause there and visit his beloved friend the Archbishop. Even the arbitrary Grand Monarque could hardly have refused such a reasonable request; but he dreaded (probably almost without knowing why) the influence of Fénelon upon his grandson, and a hampered, qualified permission was all the Duc de Bourgogne could obtain. The Duke was strictly forbidden, not merely to sleep at Cambrai, but even to dine there; and in order to make sure of his having as little com- 
munication as possible with Fénelon, the King forbade him to alight, so says Saint Simon.x But even this limited prospect was grateful to him who thirsted once more to sun himself in the warmth of the truest affection he had ever been blessed with, and he wrote to Fénelon as follows :-

$$
\text { “A Peronne, April 25, } 7 \text { o'clock, I } 702 .
$$

"I cannot be so near you without expressing my delight, as also that which the King's permission to see you gives me. He has subjoined the condition that I am not to see you alone; but I can obey that command, and still talk with you as much as I will, as I shall have Saumery as the third in our first meeting after five years' separation! It is sufficient to mention him; you know even better than I do that he is a very safe man, and better still, your true friend. So I intreat you to be at the place where I am to change horses about eight or half-past. If by chance an excess of discretion should have taken you to Cateau, I bespeak a rendezvous on my return, assuring you that nothing ever has or can alter the sincere affection I have for you, etc.

LOUIS." 2

The Duke knew Fénelon well, and had rightly foreseen that, in order to avoid any possibility of appa-

- Mémoires, vol. vi. p. 146 .

${ }^{2}$ Correspondence, vol. i. p. I30. 
rent wrongdoing, he would leave Cambrai at the time his former pupil was to pass through. However, the King's permission set this difficulty at rest, and the Archbishop and his "petit Louis" met once more, though in a constrained, uncomfortable manner, surrounded by lookers-on at a moment when both their hearts yearned for an unreserved private interview. Saint Simon says that the very crowd was touched at the transport of joy which the young Prince could not restrain, in spite of all the chilling formalities imposed upon him, when he caught sight of his beloved friend. He embraced Fénelon over and over again, and continued to whisper loving words as he did so; but both were too loyal to infringe upon the King's commands. The royal party only remained long enough to change horses leisurely, and the meeting was frozen by form, until just before they parted. When the Archbishop was offering a napkin to the Prince as he washed his hands, Louis said in a raised tone, intended to be heard by all present, "I know what I owe to you ; and you know what I am to you" ("Je sais ce que je vous dois, vous savez ce que je vous suis"). "The scene was too public and too narrowly watched not to be made known everywhere," says Saint Simon; "but as the King had been strictly obeyed, he could not find fault with such utterances as could be snatched amid embraces, or with the loving and 
expressive looks exchanged between the Prince and the Archbishop. The Court gave good heed to all this, and still more the army. The consideration which the Archbishop had won for himself in spite of his disgrace, throughout his diocese and in the Low Countries, spread through the army, and foreseeing people selected the route through Cambrai, in preference to any other, on their way to and from Flanders."

Fénelon wrote on the evening of that interview to Mine. de Montberon:- "I have seen the Duc de Bourgogne to-day, after five years' separation, but God seasoned the consolation with great bitterness. . . . I saw him only in public, for a short quarter of an hour. One must take things as they come, and give one's self up unreservedly to God's Providence." x

Writing soon after to the Duc de Chevreuse, Fénelon expresses his joy at hearing that the Prince was exceeding all hopes in his conduct in Flanders, "in which he is strengthened by his religious tone. This experience must induce him to take a new line when he returns to Court; unless he starts on this fresh footing at first, he will fall back into the old state of things, and all the good gained with the army will be lost. Two misspent days at Versailles will be his destruction. On the other hand, if he - Correspondence, vol. vi. pp. 379, 380. 
maintains the reputation he has won; if he is found to be affable, obliging, attentive at Versailles as when with the army; if he maintains a certain dignity, without hauteur or quick temper, even towards those least prejudiced in his favour, you will see that the public will appreciate it, and even the least favourably disposed will not be able to help perceiving his worth. If he will take the trouble, he will make himself esteemed by everybody; he need only act in a really religious spirit-that will uphold him in all." And in another letter, written a fortnight later, the Archbishop expresses a similar urgent desire that the Duke should keep up the improvement wrought by his sojourn in the army at Versailles. ${ }^{x}$

The campaign was not eventful, and in September Louis XIV. recalled his grandson, who wrote most affectionately from Malines (Sept. 6, I 702) to express his fears lest a renewed meeting should excite the King's displeasure and do harm. However, the lettcr was delayed, and as a matter of course Fénelon went to the post-house to meet his dear "petit Duc," writing afterwards to de Beauvilliers that he had improved in personal appearance, and was most affectionate. The Archbishop knew his former pupil's character so well, that he could not help feeling the present to be a critical period, and he accordingly

correspondence, vol. i. p. I54. 
intreated de Beauvilliers to take a most faithful and prayerful line about one whose character was so allimportant to the welfare of France. There are many letters on this subject. Some extracts must be permitted: it is not often, perhaps, that such true and loving counsels are uttered on behalf of princes :-

$$
\text { "Cateau-Cambresis, Oct. 5, } 1702 .
$$

"I intreat you, my dear Duke, not to let any mere political views influence your dealings with the Duc de Bourgogne, nor any over-anxious foresight or mere secular plans, or any excessive caution or overreliance on his natural discretion-all such machinery would fail in the hour of need. Deal quietly with him, without anxiety, and simply as in the Presence of God. Do not seek him overmuch, let him seek you; do not indulge him weakly. On the other hand, beware of exercising indiscreet authority. Do not constrain him, or worry him with importunate lectures; but tell him the truths he ought to know simply, gently, and briefly. Never say much at a time, and that only according to his needs and opportunities."

And in Jan. I703, the Archbishop (after wishing his old friend a happy new year, no physic, a little rest, and plenty of cheerfulness, since joy is the true baume de vie, and "a broken spirit drieth the bones," 
Prov. xvii. 22) bids him study the Duc de Bourgogne's inner life still more than the external, nourishing his heart, and strengthening him so that his natural tastes, his impetuosity, and the world's stream may not carry him away. "I should think less of his indifference to the world while it was against him than of his being able to be detached from the world now that it sings his praises and seeks him eagerly. The thing is to act fittingly as regards the world, without caring for it, and that cannot be accomplished unless God upholds a man with His Hand, as though he hung in mid-air. What can be more flattering than to be born so great a prince, and yet to owe public applause to one's own conduct and abilities, like a mere private individual? But it would be a terrible misfortune if he leant on such a broken reed. The esteem of empty men is empty, and will be forfeited some day. If the Prince be left to himself, apart from God and His Grace, all will wither up around him, and the very world which led him to forget God would be God's instrument for punishing his ingratitude. I would die rather than hear of such a calamity. Assuredly, if he were to fall from God, he would be in a condition which would speedily lose him with the world, and the world would turn from him."

Again :- "I am delighted at all I hear of the Duc de Bourgogne. Try to influence him so that those 
who are charmed with him in the army may find him as charming at Court. I know the unavoidable differences, but we must try to bring the two things as near together as possible. The only sure way is for that which is good to be thoroughly established within him, and then to overflow on all that is without. Grace is to the soul what food is to the body. A man who strove to feed his arms and legs by applying the best possible food to them would not gain flesh. All must begin from within: the food must be digested and become chyle, blood, and finally sound flesh. It is from the very centre of life itself that all external parts acquire their nourishment. And prayer to the soul's life is as the digestive organ to the body. Love digests everything, absorbs everything, and assimilates all it receives; it nourishes all the exterior man by good deeds. As the digestion forms flesh, blood, nervous power for arms, hands, legs, feet; so love in prayer renews the spirit of life for all its course. It forms patience, gentleness, humility, purity, temperance, disinterestedness, sincerity, and all the other virtues necessary to repair their daily waste. If you strive to apply any such virtues externally, you only produce a formal method, a superstitious exterior, a collection of legal, judaising works, a lifeless form. It will be a mere whitened sepulchre: the outside may be garnished with sculptured marble, with a bas-relief of 
virtues, but within will be only dry bones. The interior will be lifeless, a mere skeleton, withered up for lack of the Holy Spirit's unction. It is no good to try and excite love within by a multitude of external practices and scruples; but, on the contrary, the inward principle of love, cultivated by prayer at certain fixed hours, and maintained by the familiar Presence of God throughout the day, must convey nourishment from the central source to the exterior members, and bring forth in all simplicity the virtues suitable to each passing hour and occasion as they are required. This it is, dear Duke, which I heartily desire you may be able to teach our Prince, who is so precious in God's Sight. Religion taken thus becomes gentle, kindly, simple, exact, firm, without being scrupulous or harsh. Take care of his health; he will be wanting in his duty to God if he does not husband his strength."

There was much to make Fénelon anxious about his dearly-loved pupil, whose noble qualities and special difficulties of character no one probably knew or felt so thoroughly as he did. ${ }^{x}$ His passionate, eager tem-

x ". . . Fénelon, plus difficile que ses autres précepteurs et plus clairvoyant, voudrait le voir un homme, un grand prince, ouvert, sociable, accessible à tous, non étroit ni particulier, ni renfermé et borné à un petit nombre de gens qui l'obsèdent et qui l'admirent-à une coterie, comme nous dirions; ayant de la religion la moelle et l'esprit, non pas les simples pratiques minu- 
perament had been, as Saint Simon says, "so mastered by grace, that the work seemed simply miraculous, so vast was the change wrought in a short time, amid the most impetuous outbreaks of youth, and amid all the countless obstacles which age, rank, and individual circumstances seemed to combine in order to contend for the victory against that grace. Yet none of these obstacles could touch the victory won, and its continued firmness removed all anxiety as to its permanence." $x$ But the very strength of the character thus won by grace inclined it to extremes, and shunning the profligacy and dissipation and selfishness of his Court and times, the young Duke was in danger of falling into a narrow groove of asceticism and selfisolation, which, if allowable to a private individual, free to choose his own line, could not but be wrong in one whose vocation called him to so eminent a public position. Writing to the Duc de Beauvilliers about him in 1710,2 Saint Simon laments that the Duc de Bourgogne gives himself up so much to study, while admitting that in his condition high

tieuses et les scrupules, s'inspirant de lui-même dans les occasions, prenant sur lui, brave à la guerre, sachant y acquêrir de la gloire, sinon par des succès éclatants qui peuvent manquer, par sa fermeté du moins, son génie et son esprit de ressource jusque dans les tristes événements."-Nouveaux Lundis, vol. ii. p. 136.
" Mémoires, vol. xv. p. 47.
2 Itid. p. 46. 
mental cultivation is necessary. But, he urges, the Duke has already attained a height therein far beyond anything he can possibly require; and having become a man, he ought to turn his energies rather to the profitable use of what he has acquired than to a continual amassing of increased stores; like a workman, who, having collected his tools, sets to work without delay to turn them to account.

Saint Simon presses the desirability of more free intercourse with the King and the Dauphin, more sociability with men in general, a less scrupulous and constrained piety, less shunning of fêtes and amusements, a smoother brow and easier manner, which, he says, would "make his piety more winning, I dare not presume to say less alarming." The very entrain with which his natural temperament led the Duke into pleasures which his conscience reproved, caused him to put literature, science, and piety in their stead with too keen a reaction, according to Saint Simon. "The violence he had done to his natural faults, his craving after perfection, ... imparted an austerity which infected everything, and gave him a constrained manner, often unintentionally that of a censor, which estranged his father more and more, and displeased the King." $x$ $\mathrm{He}$ would refuse to be present at Court balls and parties on certain occasions, and shut himself up in

I Mémoires, vol. xv. p. 80. 
his study when others thought that duty demanded the sacrifice of his personal feelings. It is only fair to add Saint Simon's concluding sentences:- "But with praise I must conclude as I began. That grace which had begun with such speedy miracles achieved its work fully, and made him a most admirable prince. All pettiness and scruples and infirmities vanished, and left him perfection in every way. But alas! perfection is not meant for this world, so unworthy of it. God showed what he could be as a witness of His own Goodness and . Mercy, and then hastened to take him away in order to reward him and punish our sins."

These criticisms of the astute politician and courtier throw an interesting light on the intercourse carried on between the Duke and Fénelon, who was fully alive to his pupil's dangers, and who, while above all cherishing his spiritual life and progress, was far too wise not to feel forcibly that those could only attain their fitting proportions by means of a faithful performance of the daily duties of that life and vocation in which God had placed him.

The correspondence between them is too valuable and interesting to be omitted, and seems to find its fit place here, rather than among Fénelon's spiritual letters.

It was generally expected that the Duc de Bour- 
gogne would have been sent to Flanders again in 1703; but whether, as some supposed, in order to keep him effectually apart from Fénelon, or for other reasons, Louis XIV. sent his grandson to Germany, as nominal Commander-in-Chief of his armies there, under the charge of Maréchal de Vauban. Fénelon's advice to the young Prince, given through the Duc de Beauvilliers, was of the most practical and sensible kind. While assuming that he would never permit any excessive drinking at his table, the Archbishop urged that he should promote pleasant and easy conversation, not hurrying away churlishly the moment a meal was ended; and that in all social hours he should cultivate friendly, affable habits. If offences against decency or morality in the army came under his notice, he was right to repress all such severely; but he ought not to descend into minute details, or indulge scrupulous fancies. He was bound to take care of his health, to sleep and eat well, and try to lead his daily life as in God's Presence, in the peace of a good conscience. The royal pupil seems to have striven to follow this advice, for Saint Simon says that he "won great honour through his application and assiduity in his work, combined with a natural, simple valour quite free from affectation, going wherever he was wanted, or where he had anything to see, or learn, or order, without thirking of 
danger. . . His liberality, his care of the wounded, his affability and appropriate demeanour towards all men, won him the hearts of the whole army." x

The Duke was recalled unexpectedly by Louis XIV. and he reluctantly returned to Versailles, September 22, 1703, whence he wrote to Fénelon on the 28th :-

"The line I have been upon this year was not compatible, dear Archbishop, with the rendezvous I gave you at our last meeting, but I profit by my usual message-bearer, and hope you will use him on his return to bring a reply. My desire to be God's only is unchanged, and even grows stronger at bottom, but it is hindered by many faults and much dissipation. So, I intreat you, redouble your prayers for me. I need them more than ever, being still weak and miserable. I see it daily more and more. But I consider that this light comes from God, Who ever sustains me, never quite forsaking me, though often I feel nothing but coldness and sloth, which I must try to conquer with the help of His Grace. For some time, too, I have been troubled with scruples which have worried me. This is a pretty fair account of myself at present; so help me with your counsels and prayers. Your name is every day mentioned in mine, though, as you may guess, it is not spoken out loud. 1 Mémoires, vol. vii. p. 89. 
Thank God, too, for the successes with which $\mathrm{He}$ has favoured us, and ask the continuance of His protection in a situation where we need it so much. I will say nothing of what I feel concerning you; I am ever the same, and greatly long that it did not depend upon going into Flanders or not whether I can see you. But all that will be as God pleases. If the Abbé de Langeron is at Cambrai, say a little word to him from me, cautioning him about secresy." ${ }^{x}$

During the next five years the King kept his grandson at Court, away from the scene of a war which was not increasing the glory of France, and it was not till I 708 that the Duc de Bourgogne was allowed to resume military duties. $\mathrm{He}$ writes (Senlis, May 15, 1 708):- "I am delighted, dear Archbishop, at the opportunity given me by the campaign I am about to make in Flanders to embrace you once more, and renew in person my assurances of the tender love I must bear you all my life. If it were possible, I should have greatly liked to sleep at your house; but you know the reasons which oblige me to be cautious, and I do not think you will stand on form. I shall be at Cambrai to-morrow about nine o'clock, get a mouthful of food at the post-house, and continue on horseback to Valenciennes. I hope to see you there, and talk of many things. If I do not often

I Correspondence, vol. i. p. 15 I. 
write to you, you know that it is from no lack of friendship and gratitude." ${ }^{\prime}$

This interview took place, subject to much the same restrictions as that of 1702 , says Saint Simon, ${ }^{2}$ except that the Duke dined at Cambrai. "To be sure, it was only at the post-house, where the Archbishop and everybody in Cambrai appeared. The curiosity felt about this very public interview may be imagined. The young Prince embraced his Preceptor repeatedly, and said out loud that he could never forget the great obligations he was under to him. Without ever whispering, he scarcely spoke to any one else, and his urgent glances directed to the Archbishop (lancé dans les yeux de l'Archevêque)looks which silently spoke all which the King had forbidden-were filled with an eloquence which, together with his first words, carried away all the spectators. ..."

On the 2 Ist he writes from Valenciennes:-_... I am delighted with the advice you give me in the second part of your letter, and intreat you to renew it as often as you will. I think, thank God, that I have some of the sentiments you suggest, and that, letting me know what is lacking, God will give me strength to attain and to use the remedies you prescribe. It seems to me that, considering how seldom × Correspondence, vol. i. p. 213. 2 Mémoires, vol. xi. p. 179. 
we meet, you still know me pretty well! . . . Continue your prayers, I beseech you; I need them more than ever. Unite them to mine-or rather I will unite mine to yours, for I know that the Bishop is superior to the Prince. You do wisely not to come here, as you may judge by my not sleeping at Cambrai. I should most certainly have done so but for the decisive reasons which hindered me. Otherwise I should have delighted in seeing you while I am here, and in talking with you about many matters in which you are more capable of enlightening and advising me than any one. You know the love I have ever borne you, and that I have always done you justice amid all the unjust accusations laid against you. Be persuaded that nothing can lessen that love, and that it will last all my life." ${ }$

The campaign of 1708 was not a happy one for the Duc de Bourgogne, whose principles and self-command were most severely tried during it. Nominally at the head of the French army, he was practically subject to the Duc de Vendôme, whose inıetuous courage, no less than his vehement temper, caused a series of difficulties to the young Prince and all around him. Moreover, Vendôme was prejudiced against the Prince, and from the first treated him with an insulting tone of superiority which was most trying to

$$
\text { I Correspondence, vol. i. p. } 214 \text {. }
$$


one whose own temperament was naturally so fiery, however subdued by grace and training.

This is not the place to give military details, or to describe the campaign. Suffice it to say, that, after losing the battle of Oudenarde (July I I, I 708), Vendôme, infuriated at his own failure, lost all self-control, and while consulting with the generals as to what should be their next immediate step, he grossly insulted the Duc de Bourgogne, who was about to speak, by exclaiming before the assemblage, in an imperious voice, that the Duke had better remember he was there only on condition of obedience to himself $!^{3}$ These tremendous words, uttered at such a moment, when the fatal results of obedience paid to Vendôme's indolence and obstinacy were but too evident, Saint Simon says,

× Saint Simon, Mémoires, vol. xi. p. 21 I. According to this chronicler, the loss of the battle of Oudenarde was really owing to the indolence and incapacity of Vendôme. "The Duc de Bourgogne, supported by the whole army, and even by Vendôme's own greatest admirers, vainly represented to him that since the suggestion [to pass the Scheldt, burn Oudenarde, and close the country to the enemy] was the only profitable course, as he himself admitted, it was better to take such a course now than leave it to be taken hereafter; and that if delayed, they might be forestalled, which, as he admitted, would be extremely awkward. Vendôme was afraid of the fatigue of marches and change of quarters, which upset the ease of his life. He was always regretting the comforts he left behind, and these considerations triumphed" (p. 206). Saint Simon's account of the battle and attending circumstances, related to him by Biron and other eyewitnesses, is most graphic and interesting. 
made all who heard them quiver with indignation. "The young Prince to whom they were addressed had to win a harder victory than that which had just been won over him by the enemy. He felt that there was no medium between extreme measures and absolute silence, and was sufficiently master of himself to preserve the latter. Vendôme began to discourse about the battle, trying to make out that it was not lost, and that as one-half of the army had not been engaged, battle must be renewed next morning-in order to which they must remain all night where they were, and make the best of it. Everybody listened in silence to a man who refused to be contradicted, and who had just shown in the person of the heirapparent how he would treat any one who dared differ from him. This silence lasted, no one venturing to speak, till at last the Comte d'Evreux broke it." One after another began to bring in tidings of the utter disorder of the French troops, and the principal officers present urged the importance of taking some decided measure. At last Vendôme, who was maddened with rage at seeing every one against him, exclaimed, "Very well, gentlemen, I see you all will have it so-we must retreat." And then, turning spitefully to the Duc de Bourgogne, he added with pointed sarcasm, "Indeed, for long, Monseigneur, I know you have wished to do so." The vicious double 
entendre meant to be conveyed in these words was perfectly plain both to the Duke and all bystanders; but he once more controlled himself in spite of the exceeding provocation, and uttered not a syllable, and, following his example, all around were silent, only expressing by significant gestures their amazement. At length Puységur broke the awkward silence by asking how the retreat was to be conducted? A general confusion ensued. Everybody talked except Vendôme, who remained silent, either from confusion or rage, till at length he said they must fall back upon Ghent, without saying how, or giving any orders. After much that was perplexing and annoying, the retreat began, Vendôme doing nothing-in fact, not being seen again. The whole details are equally discreditable to him and creditable to the Duc de Bourgogne. The latter wrote briefly to the King, leaving Vendôme to give details; but to his wife he openly denounced the obstinacy and supineness of Vendôme as causing the defeat, adding that such another event would make him leave his profession, but for the precision of his orders and the blind obedience due to them. The same courier carried a letter to the King from Vendôme, in which he tried to make out that the defeat had not been so absolute ; and shortly after he wrote again, assuring the King that he would have conquered had he been better 
supported ; and that if, contrary to his opinion, they had not retreated, he would certainly have defeated the enemy on the following morning, referring Louis XIV. to the Duc de Bourgogne for details. There is a curious little bit of behind-the-scenes, in which we find the King opening and reading all the private letters carried by the same courier from various officers to their wives and friends!

Saint Simon goes into a copious narration of the cabal at Court against the Duke, and its aims-" pour n'avoir point à compter avec lui du vivant du roi, et à sa mort s'en trouver débarrassés pour gouverner Monseigneur sur le trône." The Duc de Bourgogne did not perceive how much it behoved him to give the true details which Vendôme withheld; many lies were told and propagated, and the cabal bid fair to succeed in its aim, which was, as Saint Simon says, to attack the Duke in the most vulnerable place, and deprive him of what is priceless to men of the world, his honour. ${ }^{x}$

The old courtier draws a touching picture of the young Prince's state of harass and discouragement, his religious principles preventing him from giving way to his righteous indignation, and his terror of the King ${ }^{2}$ making him believe that all Vendôme said

× Mémoires, vol. xii. p. 2.

2 Saint Simon says, "sa frayeur du roi,-ce serait trop peu dire la crainte. . .." 
would be believed. Fenelon, whose intense interest in his pupil kept him always alive to and well informed concerning all that was going on, was dismayed to hear that there was a risk of the Duke's throwing up his command, and returning hastily to Paris. He wrote urging the Vidame d'Amiens to do what he could to prevent this, and to the Prince himself he wrote:-

\section{"September I 708 .}

"I do not wish, Monseigneur, to meddle with affairs beyond my ken, especially military matters, of which I am profoundly ignorant; but knowing your goodness, my excess of zeal makes me take the liberty of saying that I hope you will take every step possible to remain at the head of the army to the close of the campaign. When a great Prince like yourself, Monseigneur, cannot win glory by brilliant successes, he should at least strive to win it by his firmness, his talent, and his power of resource under trial. I am convinced, Monseigneur, that this is the bent of your own mind. It is not yours to do what is impossible; but what will sustain the repute both of the King's arms and your own, is, that you do to the end whatever a proved old captain could do to reinstate things. Then wise men will do you justice, and in the long run wise men generally lead the public 
mind. Bear with this indiscretion on the part of the most faithful and attached of your friends." ${ }^{\prime}$

The annoyances which were heaped upon his beloved Prince did not fail to reach Fénelon, and he hastened to write the following letter to him, the admonitory tone of which testifies the hearty affection borne by each to the other:-

\section{"Cambrai, September 16, 1708.}

"Monseigneur, I can find no comfort under the trials you are experiencing, save in the hope of the benefit which God will bring forth for you from them. As S. Augustine says, God often gives temporal prosperity even to the wicked, to show how utterly He despises the good things which dazzle the world. But He keeps crosses for His own children, for those whom $\mathrm{He}$ desires to detach, to humble beneath His powerful Hand, and make the subjects of His Goodness. 'Et quia acceptus eras Deo, necesse fuit ut tentatio probaret te.' ${ }^{2}$ There is always a considerable lack in any man, however great, who has never experienced adversity. The Wise Man says, 'Qui non est tentatus, quid scit?' 3 One does not

× Correspondence, vol. i. p. 224 .

2 Tobit xii. I3 (Vulgate). The English version altogether loses this passage, "Because thou wert acceptable to God, it was needful that thou shouldest be proved by temptation."

${ }^{3}$ Ecclus. xxxiv. 9. Fénelon cites these passages in French, 
know other men, or one's self, if one has nerer been subject to misfortune, in which the real trial both of one's self and of them is brought to bear. Prosperity is a torrent which bears you onwards, and in which all men offer you an incense which intoxicates you. But adversity is a torrent which drags you down, and against which you must harden yourself unremittingly. Great princes need the lessons of adversity more than other men; lessons which for the most part are wanting to them. They need contradic. tion, that they may learn to be moderate, just as humbler people need encouragement. Without contradiction princes 'are not plagued like other men,' $x$ and forget their human nature. It is well that they should feel that all things may slip from them, that their grandeur is fragile, and that the men now at their feet would fail them were that to fail. It is well that they should learn not to risk going to the extreme end of their power, but know how to put themselves in other men's places, thereby to learn consideration. Of a truth, Monseigneur, it is far more important to the real welfare of princes and their people that the former gain such experience than that they be ever victorious. What I feared for you was the flattering delight of command-

but the English version so entirely loses their point, that it is necessary to give the words of the Vulgate.

Ps. Ixxiii. 5. 
ing so powerful an army. I prayed to God that you might not be as the king of whom it is written, 'Gloriabatur quasi potens in potentia exercitus sui.' ${ }^{x}$ The greatest princes have only a borrowed power. Their confidence is indeed vain if they imagine themselves strong by reason of the multitude of their forces. A contretemps, a shadow, a mere nothing brings disaster and terror into such forces. I was moved to tears when I heard you so devoutly say, "Some put their trust in chariots, and some in horses, but we will remember the Name of the Lord our God.' 2 Many common minds imagine that a prince's glory depends on success: it really depends on well-chosen measures, not on the success of those measures; and not even wholly on well-chosen measures, for the errors into which the most able princes are liable to fall may be turned to account, and enhance their repute, if they know how to use such aright.

"The true glory of princes depends only on their virtue. They must be admired if they prove then:selves good, wise, courageous, patient. Adversity confers a lustre on them which is not to be found in the most brilliant prosperity. It brings to light capabilities which the world would never have seen if all things had taken shape according to their wishes. The

Judith i. 4 .

${ }^{2}$ Ps. xx. 7 . 
greatest of all victories is that wherein wisdom and courage are victorious over misfortune.

"No more striking instance of this could be afforded than that of Saint Louis. He fought for the faith, and because $\mathrm{He}$ loved him you know how many crosses God laid upon him. I often pray that the descendant of that great King may inherit his virtues, and that you may be, as he was, a man after God's own Heart. I should greatly rejoice if you might do great deeds on behalf of the King and country; but if God does not will this, I would have you at least do well and thoroughly all that is given you to do. I doubt not, Monseigneur, but that you will do it: if you are faithful to God, He will lead you by the hand.

"Dare I tell you what I hear the public say? If I only consulted prudence, I should not do so; but I would rather run the risk of seeming indiscreet than fail to tell you what may be useful to a character like yours. You are sincerely esteemed, you are tenderly loved, there are great hopes as to the good you may do ; but the world says that you are not sufficiently decided, and that you yield overmuch to counsels which are very inferior to your own instincts. Not knowing the facts, I do not know who the persons alluded to may be, and do but tell you literally what I hear.

"It is true, Monseigneur, that your submission to the King's will should be absolute, but you are bound 
to use the powers he confers on you to the utmost in his service. Moreover, you ought to make the strongest representations, if you see that it is necessary to enlarge those powers. A thoughtful prince, accustomed to business, and who has led a steady life, closing his third campaign at the age of twenty-seven, cannot be considered too young to exercise decision of his own. The Duc d'Orléans has absolute power in the Spanish war; and experience has shown, Monseigneur, that a deliberate and well-regulated line of conduct may be looked for from you. It is not a question of decisions in which you might stand alone, opposed to all the general officers of the army; suffice it if you are free to follow what you think right, when your opinion is confirmed by that of the most experienced and well-known officers. There would be much less risk in giving you such power, than in keeping you bound and subject to the mind of an individual, or always waiting the King's decision. There are urgent cases where to wait is to lose the opportunity, and in which no one can decide save those who are on the spot.

"I ask your pardon, Monseigneur, for this freedom of speech, which arises from my ardent zeal. I have, thank God, no interests in the world; I care only for yours, which are those of the King and the country. I know to whom I speak, and cannot doubt the good- 
ness of your heart. Mine will be devoted to you all my life, with the most inviolable affection and the truest respect." $x$

The Duke's answer to this letter is as follows :-

"Camp of Saulsoir, Sept. 20, 1708.

“. . . It has not been a question of my return, but you may rest assured that I am and have always been of your mind in this matter, and that unless I receive peremptory orders, I intend, come what may, to finish the campaign, and remain at the head of the army. It is true that $I$ have had a severe trial during the last fortnight, and I know that I have not borne it as I ought; I let myself be carried away by prosperity and overwhelmed by adversity; I yield to the depression and disgust caused by contradiction and uncertainty, and the fear of doing something amiss in matters of so much consequence to the country. I was in this position: the King repeatedly ordering me to attack the enemy, M. de Vendôme urging the same; while, on the other hand, Maréchal de Berwick and all the old officers, and the greater part of the army, agreed that success was impossible, and the army would be lost. The King renewed his commands after one representation which I felt obliged to make. ... I foresaw the fatal results of a lost

x Correspondence, vol. i. p. 226. 
battle, with little or no hope of winning it, and that the best one could hope for would be retreat after a fruitless attack. ... As to what you say about my indecision, it is true. I often reproach myself for it ; and sometimes indolence or carelessness, other times mauvaise honte, human respect, or timidity, hinder me from taking a clear course in important matters. You see I speak in all sincerity to you, and I daily ask God to give me not only wisdom and prudence, but strength and courage to carry out what I see to be my duty. I had not power to decide (cette puissance décisive) at the beginning of the campaign, and the King had desired me, where opinions differed, to abide by that of $\mathrm{M}$. de Vendôme. But I asked for such power after Oudenarde ; it was granted, and perhaps I have not used it as fully as I ought. As for the commendations you give me, from another I should look on them as flattery, for in truth I little deserve them, and the world is mistaken as to me. But with God's Help I will try to be what I am thought, or something like it."

A few warm lines from Fénelon in reply to this urge the Duke to go bravely on, putting aside his individual tastes and likings for duty, resisting prejudice, avoiding scruples, and seeking to do all as in God's Presence. And on Sept. 24th there follows a long letter which certainly is no 
flattery, for it recapitulates the Prince's faults with the unsparing hand of a true friend. "It is said that you are too exclusive, too select, and associate too much with a few who surround you. I must confess that in your childhood you were always inclined to exclusiveness, and to dislike fresh faces. Though I am sure that since then good sense and right feeling have taught you more consideration for the public (which has a right of easy access to its princes), there is, perhaps, too much of the old disposition left." As to society (the Archbishop goes on to say), the Prince has a cultivated mind, and power to adapt himself to all ; he only needs a little self-control and obligingness. "God will give you strength to mould yourself if you seek it. You will only have worldly praise to fear. The men who expose themselves to ruin or death for the sake of great princes are ready to be won by a kindly, well-timed word. 'The whole army will love you if you are accessible, frank, and kindly." Fénelon returns to the world's charge that the Duke is too much led by incompetent advisers, and that he had yielded contrary to his convictions to Vendôme, going on to mention an accusation that he sometimes wastes time in unseemly badinage, that he is not sufficiently cautious in letting his opinions be known, and does not take pains enough to inform himself of details connected with 
the army. "I thank God, Monseigneur," the Archbishop continues, "that $\mathrm{He}$ enables you to see your faults, and teaches you, even by sharp lessons, to mistrust yourself. But you must seek in God all that is lacking in yourself. ' $I$ can do all things through Him Which sanctifieth me,' S. Paul says. Live by faith, not by your own wisdom or courage. Do not be surprised at what is deficient in you ; work hard to attain it by degrees with patience, and, while working, lean only on God. He must love you very much to teach you by so many misfortunes. $\mathrm{He}$ is showing you how terrible a thing war is, how useless the most powerful armies, how easily the greatest states are moved. He shows you how severely great princes are judged by the world, in spite of the incense of their flatterers. One who is destined to govern men must love them for God's Sake, without reckoning on their love; and sacrifice himself for their good, while knowing that they cavil at his goodness and moderation. . . The world says that your devotion is gloomy, timid, scrupulous, and unsuitable to your position. ... If you want to recommend your religion, you cannot take too much pains to make it kindly, simple, cheerful, and sociable. You must be 'all things to all men, that you may win all;' you must work hard to root out your chief faults through love for God, by renouncing self-love; you must 
seek the public welfare as much as possible, and lay aside scruples as to minutiæ."

There is something very touching in the candid way in which the Duke meets all Fenélon's loving rebukes and incisive truths. "I am a much less good man than is supposed," he replies (Oct. 3, I 708) to the letter from which these last quotations are made. "I am all up and down, falling over and over again, relaxed, full of omissions and sloth in my most important duties, of self-indulgence, fastidiousness, pride, contempt, clinging overmuch to life and its good things, not loving God above all, or my neighbour as myself." $\mathrm{He}$ then goes through the accusations one by one, admitting some and palliating others. "I will try to use your advice, and pray God to give me grace not to err on one side or the other. Ask more and more of God to give me a true love for Him, and for all-myself, friends, and enemiesin Him."

On October ${ }^{5} 5^{\text {th }}$ following, Fénelon writes again in the same strain of admonition. A large part of the letter is a repetition of similar charges. "There is a complaint," he continues, "that your confessor is too often shut up with you; that he meddles with matters of war. . . . It is said that you make unwise confidences. . . . If you will but look to God on every 
occasion in humble confidence, He will lead you, and clear up all your doubts. Whatever talent $\mathrm{He}$ may have given you, you run a risk of committing irreparable faults if you give yourself up to a sickly, scrupulous devotion. . . . Your resources are endless, if you will use them. You have more means than most men of making pleasant conversation with those around you; and by a little more ease with them you would win them. A word, a gesture, a smile, a look from a prince like yourself, gains the heart of the multitude. A suitable commendation bestowed on recognised merit attracts right-minded people. . . . Nothing will so win you hearts as kindness, heedfulness of merit and services, and earnestness in rewarding them. It only depends upon yourself to earn the suffrage of the public, and of the whole world. ... I grant that nothing is more idle than to run after the empty praise of men, who are often rash, unjust, and blind in their judgment. They are happy who can ignore all such! But greatness, so far from raising you above man's judgment, subjects you to it far more than a lower position. Those who are called to rule over others cannot do it profitably if they lose the esteem and confidence of the public. Nothing could be harder and more unbearable for the people, nothing more dishonourable and dangerous for a prince, than a government of mere power, without 
esteem, confidence, and reciprocal attachment. It is most important, by God's own teaching, for great princes to study unremittingly how to be loved and esteemed, not out of mere vanity, but as a duty to God, Whose Goodness they ought to represent on earth. If such study is irksome, they must accept it as a duty, and take it as a mortification to be chosen rather that any other for the love of God. If you give yourself unreservedly to $\mathrm{Him}, \mathrm{He}$ will make some of these little efforts which now seem so hard easy to you. ...

"You ought to make religion honourable, and let it be respected in your person both by critics and libertines. Your practice of it should be simple, kindly, noble, firm, and consistent with your position. You must go straight forward in the essential duties of that position, acting on the principle of love of God, and never making your goodness importunate by scruples and hesitations in trifles. God's Love will expand your heart, and help you to act promptly on urgent occasions. A prince in camp or court cannot rule men like a community of religious: you must do what you can, and adapt yourself to your surroundings. Jesus Christ said to His Apostles, 'I have many things to say unto you, but ye cannot bear them yet;' and S. Paul, 'I became all things to all men!' I pray God daily that His free Spirit may 
enlarge your heart without relaxing your fervour, and teach you to adapt yourself to the needs of the multitude. You must show that you think seriously, stedfastly and firmly. You must let the world feel that you know what you mean, and that nothing escapes you. If you appear plastic and easily influenced, you will be led away. . . . The period of your return to Court will be a crisis. I shall redouble my poor prayers for you then. If you accustom yourself to withdraw frequently within yourself in order to renew God's possession of your heart; if you say in all humility, 'I will hearken what the Lord God will say concerning me' (Ps. lxxxv. 8); if you act neither from temper, nor natural inclination, nor vainglory, but merely as setting self aside, and in all faithfulness to the Spirit of Grace, God will uphold you. 'He shall give His angels charge over thee, to keep thee in all thy ways:' 'It shall be given you in that same hour what ye shall speak.' You will be great before men in proportion as you are lowly before God, and supple in His Hand. You will have crosses, but they will be part of God's designs for you, as the instrument of His Providence, and you will be able to say, 'I am exceeding joyful in all my tribulation' (2 Cor. vii. 4). I cannot enter God's Presence without taking you with me, and asking Him that you may be like David, 'after His own Heart." "' x

I Correspondence, vol. i. p. 252. 
Several more letters of a like character were addressed to the Duc de Bourgogne while yet absent from the Court; for though well aware of the injustice and malice of the cabal which depreciated him, Fénelon was too clear-sighted not to realise his pupil's faults, and too real in his affection not to desire to correct them. Nor could he fail to know that no one living had the same influence or power to do this that he had. Not only did he write to the Duke on the subject which lay so near his heart; his correspondence with de Beauvilliers and de Chevreuse, and the Vidame d'Amiens, turns largely upon it. "If the P. P. does not feel the necessity of a firm, vigorous course, he will make no real progress,"Fénelon writes to the Duc de Chevreuse. "It is time to play the man. The life which surrounds him is luxurious, indolent, all amusement and trifling. $\mathrm{He}$ will never be so subject to his two superiors [the King and the Dauphin] as when he makes them feel that he is a ripe, diligent, firm man, appreciating their real interests, and fit to uphold them by the wisdom of his counsel and the vigour of his conduct. Let him be more and more lowly in God's Sight, but great in the eyes of men. It is said of Solomon that men feared him, seeing the wisdom that was in him." x

It was to the Duc de Beauvilliers that Fénelon Correspondence, vol. i. p. $3^{85}$. 
wrote anxiously about the need for wisdom and charity in the exterior religious life of his beloved Prince. "I hear," he says, "that the Duke increases his religious exercises. I am most thankful to see grace ruling his heart. We may hope great things when the wish to please God conquers his youthful passions and the seductions of our corrupt age. I thank God for giving him courage not to be ashamed of His Gospel. It is most essential that a prince of his rank should publicly perform such good works as will lead men to glorify the God they profess to adore. But it is reported that the Duke goes beyond what is due to a regular and edifying Christian life. People are frightened at his strictness, and imagine that he is disposed to criticise others, and force his scruples on them. It is said that he wanted to make the Duchess keep Lent as strictly as himself, and to abstain from all theatres; also, that he is ceasing to play, and is almost always shut up by himself; and finally, it is reported that he refused to attend Monseigneur (his father) to the opera during Lent.

"I make allowance for the exaggeration of a world which detests rule, and is still more afraid of it among the great than among private persons, because the results are wider. The world often calls that excessive which is scarcely sufficient; but, on 
the other hand, I should greatly fear that the Prince might overdo external practices which are not of necessity. Without pretending to lay down the law, it seems to me-I. That he ought not to constrain the Duchess, but be satisfied to let her physician decide how she should keep Lent. . . . If he wishes to draw her to piety, he should make it attractive and loveable, put aside all that is harsh, make her feel the charm of a simple, unpretending goodness, be cheerful and accommodating in whatever does not concern principle;-in short, adapt himself to her, and wait patiently, taking care the while not to slip himself while reaching out to help another.

"II. He ought not to display his piety before the world, save on those occasions where harm would be done if he were to neglect a public observance of rule. For instance, he ought to be devout and recollected at Mass, perform his devotions freely, abstain from all levity and over free conversation, imposing silence in such matters on others by his reserve -all this would give him great weight; but when he wants to perform extra devotions, he should select such place and time as will best conceal them from mere courtiers, and he should never be demonstrative as to his opinions, which are sufficiently known. Regularity in his general duties, and steady avoidance of evil, will suffice for public edification. 
"III. I think he ought to yield to Monseigneur's wishes in whatever is not sinful. If plays were such in themselves that no one could be present at them without offending God, he ought never to go;-no more in the Carnival than during Lent or Holy Week. It is very proper for the Prince to make a rule for himself not to frequent such places during a season consecrated to penitence and prayer; but a well-timed concession is a real merit, and if it departs from the letter of the law it does but the more comply with the spirit. I should say, let the Prince abstain from theatres during Lent as far as his own pleasure is concerned, but let him go to please Monseigneur, should he require it."

It would be easy to multiply quotations from the Archbishop's letters to his "little Duke," conveying the soundest advice as to his conduct towards the various personages and parties with whom he was brought in contact, but while the general tone is very similar, the more minute details scarcely concern a sketch like this. It is difficult to realise that this was the counsellor so dreaded by Louis XIV. for his grandson, that all communication still had to be carried on in the most secret and cautious manner, and that any of Fénelon's personal friends, after a visit to Cambrai, were wont to abstain from appearing at Court a while, lest it should be supposed 
they were acting as channels of such communication!

The Duc de Bourgogne had great need indeed both of sympathy and good counsel. After his return from the Low Countries the cabal succeeded in thoroughly estranging the weak, dull Dauphin his father from him, and the intrigues and petty diplomacy into which Saint Simon's piquant Mémoires admit one must have been a great trial to a man of his character. The year I 709 was one of great depression and suffering in France; and while the royal pupil was exerting himself in a manner worthy of his great Preceptor under difficulties and cares which were almost overwhelming, Fénelon himself was labouring in the King's service as devotedly as if he had ever been an appreciated and well-rewarded servant. His boundless hospitality to the officers and soldiers of the French army has been already described; but now, when famine and financial pressure were heavy upon the land, his liberality went yet further, and he practically provided a large part of the army with subsistence. So great was the veneration in which Fénelon was held by all European nations, that the enemy's generals had invariably respected his land and his stores. It was no uncommon thing to find a special guard mounted over the Archbishop's property, not at his request, but by the free good- 
will of Prince Eugene, Marlborough, or, others. On one occasion the latter performed a striking act of generosity of this kind. The allies were placed between Cambrai and Cateau-Cambresis, where all the Archbishop's stores were, as also those of his people which had been committed to his care. In fact, the little town was one vast storehouse. The Duke of Marlborough placed a guard upon it at once; but perceiving, that in the existing deficiency of provisions, which threatened to become a famine, it would be impossible permanently to protect so valuable a supply, he gave notice to Fénelon that he had better remove it, and accordingly a vast cortége of cars was forthwith loaded with the precious grain, which Marlborough's own troops escorted to the Place d'Armes of Cambrai, which was the headquarters of the French army at that moment.

Fénelon's first act was to give up all his stores to the army, reserving only so much as was necessary for his household and his many guests. The Comptroller-General asked him to name a price for these invaluable supplies, but Fénelon merely replied that he placed them absolutely at the King's service; and writing at the same time to the Duc de Chevreuse, he added that he was ready to give his plate and all he possessed, remarking that all he wished was to devote his money and his life, but not to court favour. 
During the winter of $1709-10$, when things were at their worst, Fénelon drew up a mémoire concerning the state of the country for the benefit of his friends de Beauvilliers and de Chevreuse, which shows at once his clear sight and his noble spirit. They made ample use of it in the Council, and the King, anxious and broken with advancing age and the declining prosperity of his kingdom, was constrained to admit the truths contained in the document, though he did not know the source whence it sprang.

It was at this time that, moved by a sense of the disasters of his country, and the almost hopeless difficulty of remedying them, Fénelon proposed calling together an "Assemblée de Notables." x

All through these years Fénelon kept up an extended and interesting correspondence with various members of his family, especially with his nephew the Marquis de Fénelon, always a special favourite and object of his care. His letters are a wonderful combination of affection and playfulness, with most earnest, solid counsel. Nothing seems too great or too little for the Archbishop's care. While telling his nephew all the family or local news likely to interest him, he gives him the wisest advice as to his duties, religious and social, cautions about his own health, intreaties to watch over the morals of a young brother

${ }^{\prime}$ Correspondence, vol. i. p. 389 . 
just joining the army; nothing is forgotten:"Good night, dear little fellow. Do not let yourself be carried away by the stream. I fear for you, though you may not fear for yourself: watch and pray. I offer you frequently to God, and I would intreat you to watch even more against the contagion of the world than the enemy's sword." ${ }^{\text {I }}$

The young Marquis was a self-concentrated, reserved person, seemingly, and many of his uncle's letters contain advice meant to counteract this disposition:- "I must scold you for not seeing more of the people you ought to cultivate. Of course the first thing is to learn and devote yourself to your duties, but you should seek their approval. . . . What I want to see in you is a quiet attention, not springing from vanity or ambition, but from a faithful desire to fulfil the duties of your position, and towards your family. . . Sometimes indolence, shyness, and self-indulgence make us shun the intercourse of people superior to ourselves. Self-love likes to dwell among those with whom we are perfectly at our ease and sure to satisfy: it is wounded when there is any risk of failure, or of being thrown into the background. In God's Name, dear child, I beg you not to neglect these things, which do closely concern the duties of your position. One must despise

${ }^{1}$ Correspondencc, vol. ii. p. 120. 
the world, but all the while realise the need there is to handle it wisely: one should be detached from it from religious reasons, but we have no right to forsake it out of mere indolence or individual likings." s

The Archbishop wished to see his nephew join the army in Germany, as a more enlarged sphere of action, and likely to be more improving. "I am very sorry," he writes, April 6, I 709, "that you are going to Dauphiné, I hoped you would see some service in Germany; but one ought to be prepared for everything, and content to be wherever one is sent. If the rumours we hear of peace are true, we may soon see you again. Meanwhile, work unremittingly at whatever will be most for the good of your regiment and the service generally. Try to make yourself liked; be gentle and obliging, though not weak; quick to discern merit among your' subalterns, without slighting any one; attach yourself to those officers who are your superiors, win their esteem, and learn from them. Take care of your health; don't reckon too much upon it when seemingly good, it may quickly fail. . . . Let us hear from you wherever you are. Remember that I shall always long to hear, and that I shall be very anxious unless at least I know that you are well. Good-bye, mon cher enfant. I pray God to have you in His holy keeping, to make you faithful to His Grace,

- Correspondence, vol. ii. p. 123 . 
and humbly distrustful of self, fulfilling His Will in everything." "

$$
\text { "July 10, 1709. }
$$

“... I want you to take care of your health, without falling short in any of your duties, or in any opportunities of acquiring military knowledge. Your failures will not hurt you; on the contrary, they will be useful, by humbling you, and keeping up a wholesome mistrust of self, and throwing you more constantly on God, so long as you are mindful of recollection, prayer, reading, and so much steady frequenting of the Sacraments as your restless life will allow of. Be sociable generally, but in private life avoid familiarity with men of loose or questionable character. Attach yourself to worthy people, seeking their friendship and esteem, but substantially trust little to men. God is the One faithful Friend Who can never fail. Tenderly as I love you, I intreat you never to rest upon me, but always to see God Only in me, in spite of all my infirmities. The enemy is besieging Tournai; the trenches were opened on the 7 th. It is not known yet whether Marshal de Villars will come to its succour. The whole country is in extreme suffering, cruelly ravaged by the enemy, while our own troops, too, overrun it terribly. God

- Correspondence, vol. ii. p. IoS. 
grant that the campaign may end without any great calamity." "

“July 10, I710.

"The Chevalier de Luxembourg tells me that he is really fond of you, but that you are too formal with him. Beware of being less so. You cannot show him too much deference or respect; but you should avoid a certain ponderous kind of ceremony and oppressive stiffness. . . . I hope you will watch over your little brother, and see how he behaves in company,-it is a good opportunity of knowing him. There are some faults into which you must not let him fall; you must teach him to be gentle, courteous, moderate, just, true, firm, discreet, and obliging. Try to make him feel at ease with you, so that he may consult you and be open with you. Look after Dufort's health; see that he does not fall into any kind of excess, and tell me honestly how he behaves."

"July 25, 1710.

". . What you say makes me think that some great engagement may be brought on almost by insensible degrees. May God turn all to good, and preserve both France and the people who are dear to us. ... Is it possible that the wish to increase our ' Correspondence, vol. ii. p. II2. 
possessions, or to seem to gain a few steps, should involve us in a battle which might be a risk to the whole kingdom?"

\section{"Aug. 19, 17ro.}

"Although you do not condescend to give us tidings of yourself, fine gentleman that you are, I am delighted to send you our news. We are all well; I am taking the Saint-Armand waters, as in other years at this season. . . . Tell the Connétable ${ }^{x}$ that I often ask how he is behaving, that I want to know whether he is courteous, taking pains to please good people, trying to be like them, rather than to follow his own ways, earnest in following good advice, brave in trying to correct his faults, and diligent in learning all business. All this is a good deal to ask, the Connétable will say, but the 'good deal' is not at all too much. I want to love him, but I shall only be able to do it in so far as he will help me by being loveable."

The Abbé de Beaumont, who, it will be remembered, was another nephew, was in trouble about his sister, Mme. de Chevry, who was dangerously ill, while the conduct of her husband added greatly to her distress and that of her family. Many of Fénelon's letters

× The younger brother of the Marquis. 
are full of kind thought and wise counsel on her behalf. "Do not be too ready," he writes to de Beaumont, October 30,1710 , "to take the advice of friends who are over-excited through friendship for the invalid and indignation against her husband. Be patient in taking the gentlest and surest steps, so that the most malicious critics may have no excuse for finding fault. Your profession demands unlimited gentleness, patience, and meekness, especially with your sister's husband. . . . There is a gentle, patient nobleness in real piety, which knows how to adapt itself to every trial. I pray God to give it you in every word and deed. Show my letter to your sister; she may rely on me in whatever depends on me. If she should be in a fit state to be moved here in a very easy litter, a thing I should greatly wish, but fear is impossible, all the objections must be considered."

To the Abbé de Salignac, another great-nephew, the Archbishop writes :-

" Dec. 10, I710.

"I am very glad, my dear child, to hear through your brother that you are doing well. It rests with you to be of the greatest comfort to me, by doing your best to advance in study and piety. You cannot be too grateful or docile to those who are taking so much pains to teach and mould you. You should avail yourself of all opportunities, public and private, 
for it is only by continual practice that a man can become a good scholar. But beware of presumption and obstinacy in discussion; they hinder the understanding, lead to the most dangerous errors, and are offensive to God and man. Argue vigorously without losing your temper; put your doubts forward clearly, and accept conviction gladly when you are wrong. I love you dearly, but I wish to love nothing save for God and the Church. Having given yourself to the latter, give yourself up heartily and unreservedlythe one thing is to fit yourself to serve her without any self-interest or ambitious motives. If it might please God, I could wish that you never should win any prize, but deserve all! Mistrust yourself, do not rely on the excessive praise which friends give for encouragement' sake. Be recollected, simple, and unaffected; faithful to your duties, and to whatever grace requires of you for the correction of your faults. Mortify your intellect, and take care of your frail, delicate body. I am ever tenderly yours," etc.

To the Marquis de Fénelon :-

$$
\text { "Aug. 10, 1712. }
$$

"I long to hear of you, my dear nephew. We are well here, except for the anxiety we feel about those we love, which somewhat heats one's blood and injures one's digestion. . . . Try to act, no: as fol- 
lowing your natural tastes, or the impulses of selflove, but as in the Presence of God, according to His Will. Fall back into your place simply, as soon as any important action or main attack in which your regiment is concerned is over. ... When I know that you are awaiting some great action or siege, in which you ought to be at the head of your regiment, I am content to let you alone. So you see I am not wanting to spoil you or cocker you up like an old nurse! But I do not at all approve of your being with M. de Puységur, far from your regiment, in order to play the volunteer and adventurer here and there, and putting yourself under unnecessary fire. . . . As to the siege, ${ }^{x}$ as your regiment is not there, neither is it your business to be. . . . Try to overcome your natural impetuosity, and wait in silence and calmness to see what God requires of you, and then do it simply. You will see that whatever is excessive will thus be restrained, and what is insufficient will seem so to you, so that the Spirit of Grace will enable you unhesitatingly to keep a juste milieu. It is all I wish. I care a hundred times more for your faithfulness than your life; and in truth there is no true life save in such faithfulness, all else, however attractive to common minds, is but death. So soon as there ceases to be any prospect of action, and that you × Douai, which was taken September 8, 17 I2. 
have done all that is seemly with respect to a siege in which your regiment is not concerned, come away, en bon enfant. Up to that point remain, and God will be with you. $\mathrm{He}$ will Himself be your shield and buckler."

The young Marquis received a severe wound in his leg at Landrecies in $\mathrm{I} 7 \mathrm{I}$, from the effects of which he suffered all the rest of his life, and his uncle writes more anxiously in consequence about his reckless self-exposure :-

"I am sending an express, cher Fanfan," to know about you, feeling anxious. I do not want to make you fail in any real duty or reasonable matter, but as your regiment is with the army, why should you not remain at your post like other colonels? why should you insist on being at headquarters in order to take part in every attack? It seems to me that you ought to be with your regiment like other colonels, and only take part in sieges and assaults as they do when it is their post. It is no trifle for you to remain with the army at all with such an open wound in your leg, but at least you ought to confine yourself to your own post as other officers do. Think this over quietly

I His pet name for the Marquis. It is a marked feature in Fénelon's correspondence, how almost every near relation and special friend has some pet name by which he is usually mentioned. 
before God, and if you feel that what I say is reasonable, pay attention to it. I accept needful and rightful perils for you, and the natural anxiety consequent upon them for myself; but do not you add to both by an ambitious impetuosity which is not for God's Sake. A clear, precise answer, if you please, Fanfan! May God be in your heart, and possess it wholly. I love the two words strength and humility,-God grant they may be yours. Amen."

The kind of confidence existing between the prelate-uncle and the soldier-nephew may be seen from such passages as the following:- "When you write to me, give one sheet for whatever may be generally seen, about the siege, or things in general, and keep a separate sheet for whatever you have to tell Tonton [himself] about Fanfan's faults, or his inner life. This will make all easy as regards your brother and others, who want to hear about you. Bonjour, petit Fanfan, tu connois la tendresse de Tonton pour toi.".

The Archbishop was as eager as a fond mother to seize an opportunity of visiting his soldier-boy in camp, " to chat together a cour ouvert." $\mathrm{He}$ writes, August 30, 1712:- "As you think, Fanfan, that it will be acceptable, I will go to-morrow to see M. de Villars, and dine with him. I will not take your brothers there; they must seek charity elsewhere in the camp, they won't die of hunger. I must return 
at night. You may tell the Marshal how great the desire to see him is which makes a coward like me join the war! If he chances not to be dining at home, I will get a mouthful of bread from some other friend in camp, and come home to supper. You can guess my delight in seeing you, and hugging you again! Good-bye, petit Fanfan; God be with you. Don't forget that to-morrow is the anniversary of your wound; it is a day of special mercy to you, keep it sacred in your heart. $\bar{A}$ demain. I am so glad to see you on such a marked day."

$$
\text { "Sept. } 2 \mathrm{I}, \mathrm{I} 7 \mathrm{1} 2 .
$$

". . . Keep up a very intimate union and respectful kindliness with your [elder] brother, who deserves it in every way. We are quiet, and see little company. I am taking milk, but have nothing as yet to say of the results. My heart is with you in Him Who is our Centre and our Life. But this true life is continual death to the false life which deludes us. Try to be restful, simple, cheerful, sociable, having the Kingdom of God within you. 'Rejoice, and again I say; Rejoice. Let your moderation be known unto all men; the Lord is at hand. Be careful for nothing, but in everything by prayer and supplication let your requests be made known unto God. And the Peace of God, which passeth all understanding, shall keep your heart and mind through Christ Jesus." 
"... Do not grow slack or dissipated; keep steady to the appointed seasons for feeding your soul; try to calm the impetuosity which you know to be too keen. One cannot always avoid being taken by surprise by a first impulse, but it is most important to check the second, without which the third is stronger yet, and a passion which might have been restrained at first soon becomes so powerful that one is carried away. One has to fear vanity in one's faults; one often persists in them out of a false shame which shrinks from seeming to acknowledge them and correcting them. There is a sermon! I don't want to weary you with my preaching. Come as soon as you can. I long to see Fanfan come in at one door and Panta ${ }^{x}$ at the other."

"Dec. 6, 1712.

". . Bonjour, Fanfan. I hope that in leaving Cambrai you have not left our mutual Centre, and that our absence from one another has not lessened God's Presence within you. A child cannot always suck, or be for ever in leading-strings; it must be weaned, and taught to walk alone. You will not always have me. God must impress you a hundred times more than a vile, worthless creature like me. Do your

\section{Pantaleone de Beaumont.}


duty among your officers carefully, without pettiness, but patiently and without harshness. It is a dishonour to justice not to unite gentleness, courtesy, and kindness with it-it is doing right badly! I want you to make yourself loved; but God only can make you loveable, for you are not so naturally, owing to your stiff, rough nature. It needs God's Hand to make you supple and pliable. He Alone can make you gentle, thoughtful for others, unmindful of self, lowly as a little child. Everything else is mere foolish, vain puffing up. ... There is nothing pleasant to tell, except that Fanfan comes on Friday."

Sometimes the kindly admonitions lengthen out, as when, advising his nephew to spend a certain time at Court, Fénelon continues :-

"Jan. 7, 1713.

"I am not surprised at your disliking it-one is constrained with people whom one knows but little or not at all, and one does badly that which one is not accustomed to do. Self-love smarts when it has to 'undergo much constraint without success. You are accustomed to a simple life, made easy and acceptable by the friendship of those around you, and this spoils you. You must grow accustomed to mental fatigue in the world as to bodily fatigue in camp. The longer you postpone the labour of $2 \mathrm{~A}$ 
making acquaintance with the world the harder it will grow, not to say impossible. You run the risk of very decided failure after a certain age; and if you give it up entirely, you will spend your life in obscurity, without any distinguished friends, without credit or position, without any reward for your service, or any means of helping your family. So it is important that you should at once break the ice courageously and patiently, without heeding aggrieved self-love. Ease will gradually come with practice. You will not be shy when you know everybody and everybody knows you, when you are accustomed to the way things are done in the new country, and when you are qualified to enter into familiar conversation with those around. As soon as you have made friends with a few worthy, highly-esteemed people, they will admit you into their society, and by degrees you will get all you want. You will be courteous to every one, you will pay customary civilities to individuals, while for real society you will limit yourself to true friends. In these you must look not merely for goodness, but for a certain standing and position. Meanwhile be patient, and gain some conquest over yourself daily. Offer the constraint you feel to God ; you can fulfil His Will in performing the duties of your position. It is a good penance for past sin; it is a sacrifice of rest, tastes, 
convenience, to Him; it will be the correction of a moral laxity which seduced you under the garb of a serious, regular, well-filled life.

"As for Paris, keep some hours to yourself for work; avoid suppers, which are prolonged too late and upset all the next day; try to save some part of your mornings for yourself. Read, and reflect on what you read. I am quite aware that you cannot always be so regular; good-nature to friends must sometimes lay you open to invasion, society and the habits of the age demand it; but while giving up something to your friends' amusement, you must rescue those hours, without which you would do nothing to make you worthy of their friendship. . . Do not let the little page ${ }^{x}$ get spoilt: you must win his heart by kindliness, but premature praise spoils children. He must learn early to look upon himself as a poor little younger brother, with no prospects except those earned by merit, work, good conduct, and patience. Steady occupation will deliver your friend from the daydreams which excite his imagination. He ought never to give them any voluntary heed. God will help him to accomplish this if he seeks it with all his heart."

It was in no worldly spirit that Fénelon urged his ${ }^{x}$ A younger brother. 
nephew to take his fitting position as a soldier of the ancienne noblesse in the world. But while he had sacrificed all worldly considerations for himself, and felt that to do so was suitable to his ecclesiastical position, he naturally and rightly wished the younger branches of his family to take their fitting place in the world, and to do good service to their King and country. There is something very touching in the way in which, during the last years of his life, when few earthly things gave him so much pleasure as the society of his enfant de prédilection, this young soldier-nephew, Fénelon resolutely sent him to camp, Court, or the healing waters of Bourbon and Barège when needed, saying frequently, "I love you for yourself, not for my amusement!" and, "God forbid I should want to make you ambitious! I should like to see you deserve all the highest honours possible, while not having them, but remaining content with earthly insignificance. What I desire most is that you should not give way to luxury or to your own vain imaginations. Every time you see that you are encouraging these try to return faithfully to God; let the dangerous thought drop, just as you would let a stone fall from your slackened fingers into the water below. And in order to turn to God, you must have some occupation which will engross your mind and divert it from delusive dreams. 
dear Fanfan, how happy you will be if you learn recollection, and accustom yourself to act calmly in every detail of life through a simple, homely leaning on the Spirit of Grace! He will never fail you if you do not fail Him."

Many of the Archbishop's letters are full of minute directions and advice concerning his health, for the young Marquis suffered greatly owing to the wound in his leg already mentioned; and his cousin, Mme. de Chevry, was seemingly an intractable invalid, to whom many admonitions were conveyed through him. "It is a heavy cross to give one's self up to a wearisome treatment; one gets disgusted and at an end of one's patience. But the only thing is to turn one's courage against one's self, and to do what is necessary for recovery as to God. Sometimes, while curing the body, the senses and intellect may be very profitably mortified." And when the surgeons in Paris urged a severe operation as the best hope for the wounded leg, Fénelon urged prompt and vigorous action, adding:- "Would to God that you were here among us, with the cleverest of Parisian surgeons to treat you. I would gladly pay for him, so as to have it done under my own eyes. But we must have the very best surgeon, and he would not come here.... Your best course now is not to delay the appointed operation a day. Get the best surgeons, regardless of 
expense ; strict régime, perfect quiet; no thought, no duty, save obedience to the masters of their art; patience, calm, the Presence of God-trust in Him only. Money will not be wanting. If peace comes, as is hoped, you can save; if the war lasts, God will provide; 'Sufficient unto the day is the evil thereof.' Do not be uneasy about to-morrow-to-morrow will take care of itself. Providence, like a good mother, takes care even of sparrows. Fear nothing; if you are wanting in nothing within, you will not be left to want from without. . . . Stay patiently in bed during the course of the operation, see very few people, talk little, take all your meals alone, go to sleep very early, strict diet, perfect rest, absolute temperance. If you are faithful to God, $\mathrm{He}$ will help you to be obedient to the surgeons."

So, when the painful operation was over, the Archbishop's letters are full of tenderness and playful encouragement. "Give yourself up to God, be obedient, be brave against yourself in enduring régime, quiet and patient in spite of the tediousness.

I In this same letter, Jan. 22, I 713 , Fénelon sends thanks to a friend who "has sent us an excellent pâté de Périgucux. I would write to thank him, but that I am afraid it would make him repeat his present. The Baron has grown quite young again through eating a Périgord dish; whatever comes from his own country is more delicious than nectar and ambrosia to him." 
... What would I not give to be your nurse!" Again :- "Your sufferings, mon cher petit homme, grieve me. I am glad to find that you are more patient than I am; I should be happier if I could see you, minister to you, and comfort you, but the cross must be thorough. Courage, très-cher Fanfan; let us bear it cheerfully. This is a most precious time for the practice of faith, for realising the frailty of all things, and for resigning one's self to God. I ask that you may have confidence in $\mathrm{Him}$, and a humble patience; self-satisfied patience would be as poison."

And :- "I am grieved, très-cher Fanfan, to think of you in pain, but we must resign ourselves to God to the end. Human courage is a false thing, a mere result of vanity; one may hide one's sorrow and one's weakness, but this soon comes to an end. Blessed is the true courage that comes of faith and love! it is simple, peaceful, comforting, true, and inexhaustible, because it comes from the One true Source. What would I not give to relieve you ! Nevertheless I would not spare you any of the healing pains which God sends in His Love. I pray constantly for you, taking you daily in my heart to the Altar, there to hang you on the Cross with Jesus Christ, and to win the spirit of sacrifice for you. Nothing but detachment brings about real patience. $\mathrm{O}$ dearest child, give yourself up to God; He is a good Father, Who will carry you 
in His Arms and upon His Bosom. It is in Him Only that I love you with devoted affection," etc. etc.

When a renewal of the operation was called for, Fenelon writes :-

" March 27, 1713.

". . . The God of patience and comfort will support you, if you are diligent in seeking to maintain His Presence within your heart in childlike love. Why should we daily say, 'Our Father, Which art in Heaven,' if we do not want to be held in His Arms as tender, simple, obedient children? How do you look upon me, knowing how I love you? Yet how infinitely more fatherly, more pitiful, more loving, your Heavenly Father is than I am. All my love for you is but a faint reflection of His. He Who has counted the hairs of your head, letting not one fall uselessly to the ground, counts your every pain and trial-hour. $\mathrm{He}$ is faithful to His promises and to His Love; $\mathrm{He}$ will not suffer pain to try you beyond what you can bear, but will work your advancement out of temptation and trial. Give yourself up to Him ; let Him do as He wills. Take up the dear Cross, which will be so precious to you if you carry it aright. Learn to suffer; in learning that one learns everything. What does he know who has never been tempted? He knows neither the Goodness of God nor his own weakness. I am so very glad that you are learning 
to talk freely with the dear Duchess [de Chevreuse]. She will do you good. Simplicity enlarges the heart; it grows narrow when shut up. People generally shut themselves up in reserve through the jealousy of selflove, and a false shame which is pride. I am very pleased at what you tell me about your brothers. I cannot possibly ask them this week, when the consecration of M. d'Ypres brings a great bustle and many strangers, but after that I shall rejoice to have them freely."

As the tedious recovery goes on, Fénelon follows it with loving counsel for body and soul:- "Bonsoir, cher Fanfan. Your long sufferings grieve me for mind and body; the amount of attention paid you by so many, dissipation, vanity, and a taste for the world, are even more to feared than the surgeon's caustic. Beware, petit Fanfan, of the sweetly flatter-

× Mme. de Chevreuse must have been a wonderfully saintly and attractive woman, to judge not merely from Fénelon's friendship for her, but from all we gather from Saint Simon, to whom mere piety was not specially congenial. He says that her "virtue and piety were as true as herself all through life," and he describes her, after her husband's death, living " like a patriarch amid her family," spending her time in prayer and good works, and in kindly offices and duties to her relations. "Never was any woman so adored by her own belongings, or so respected by the world to the end of her life, which was prolonged over eighty years, in full vigour of mind and body." Mémoires, vol. xix. p. 160. 
ing poison of worldly friendship. You must receive the world's civilities with courtesy, and such demonstrations as are fitting; but keep all real intimacy and union for your true friends, who are God's children, such as the Duchesse de Mortemurt and a few others, who will give you what your most estimable worldly friends can never give. Be open with such persons, in spite of the difficulty it is to you. On the one hand, the effort expands your heart, and helps to dispossess self and self-conceit; and on the other, you want devout friends in Paris, who will make up for such little help as I can give you here, and who will feed your inner life. For want of this you might fall unconsciously into a blank dryness and dissipation which would be dangerous. ... I love you more than ever; you can never understand the nature of this love, but God, Who has caused it, may explain it to you some day. I want you to be His, not mine, and I want to be wholly yours in Him."

$$
\text { “April I, I713. }
$$

"You are suffermng, très-cher petit Fanfan, and I feel the contre-coup sorely; but we must cherish blows which come from God's Hand. It is a lighter Hand than the surgeon's; it cuts only in order to heal; all its wounds turn to blessings, if we will not hinder it. I want you to be patient without patience, and courageous 
without courage. Ask the dear Duchess [da Chevreuse] what this seeming galimatias means. The courage which one looks upon as one's own, of which one thinks highly and is self-satisfied, is a mere poisonous pride. On the contrary, one must feel weak and ready to fall; one must face it quietly, be patient under one's own impatience, allow others to see it, be upheld from one moment to another by God's Hand, and be content to live on borrowed goods. In such a state one walks without legs, one eats without bread, one is strong in weakness; one has nothing in one's self, but everything in the Beloved; one can do all things, because He Alone works in us; all comes from Him, all returns to Him. The virtue which $\mathrm{He}$ imparts to us is no more our own than the air we breathe. . . . I go out walking whenever the weather and my work will let me, but I never walk without longing for you. Still I want to wish for nothing but what the Lord of all wills, and you must do the same, without sadness or anxiety. What a source of strength it is when one has found an All-powerful Love Which protects one, and never inflicts a pang save as the means to infinite good! How much I pity those who do not turn to this Source for time and for eternity. And there are so many who reject it! Le bon Put [M. Dupuy] walks with me; but sometimes he is weary, and gets out 
of my way. He is the best of fellows. People who seek to serve God unreservedly are very delightful !

"Our dear invalid [Mme. de Chevry] boasts of her docility in a way that proves she has absolutely none! Her brother's scolding letter, I can see, has been simply a waste of time, and mine are blown away by the wind in like manner. . . . I expect that she will beat you when you read this to her; but she is welcome to beat us all, if only she will do as she is told. It is a question of severe pain and early death, and of doing a far greater wrong to God than even to her dearest friends. If nothing has so much weight with her as the dislike of self-control, I don't know what more to say to her; I can only grieve and pray for her.

"I am beginning to make acquaintance with le petit cadt. ${ }^{\mathrm{x}} \mathrm{He}$ seems to think a little, to feel, and have a will. God grant that we may find stuff in him to make a man. Men toil to make a brave, learned fellow by dint of education, and then God overthrows the card-castle. He upsets this human courage, pulls down the empty wisdom, exposes the weakness of this supposed strength. He clouds, humbles, alters everything. His work is to annul ours, and He needs but one blast to do so. He brings us to see gladly that $\mathrm{He}$ is All, and that we are nothing. This confession s One of the Ma.quis's brothers. 
is all that is leit us; and even that is not our own, we borrow it hourly from Him. We owe all we have to Him, but we can give Him nought save that which is His."

$$
\text { “May 9, 1713. }
$$

"The Elector of Cologne went through at nine this morning on his way to Valenciennes, only stopping to take some soup. This is all our news. It is said that the Hollanders are delaying the exchange of ratifications, but this is very likely a false rumour. God grant that we may soon have a general, lasting peace.

"In proportion to the time you have been reported as 'better,' you cught to be able to run like a Basque! I am afraid these 'betters' are very slow and imperceptible. ... I have given M. d'Ypres' canonry to the Abbé de Devise, not without vexing other people who asked for it. I was very sorry, but what can one do? I don't see how I could conscientiously have done otherwise."

"May 21, 1713.

"Bonjour, mon cher petit Fanfan. Blondel will give you our news, but he cannot tell you how much I long to know that you are well again. I am not anxiously impatient; I even wait quietly on God's pleasure, since His Will is dearer to me even than you, or than a thousand 'me's' put together. But when 
all is said, my soul craves for your restoration, and then I submit this craving unreservedly to Him Who is the real bond of union between us. Do not be injured at my loving you with such a love, for it is the very love with which I love God and live in Him. I have often thought of S. Paul's words in connection with you, 'Let us run with patience the race that is set before us, looking unto Jesus, the Author and Finisher of our faith; Who for the joy that was set before Him endured the Cross, despising the shame.' The world cannot understand that patience is a journey towards our true end; it fancies that patience means inaction. Besides, the world cannot understand that our end is a struggle. Men aim at a rest which shall be all glory and enjoyment. Yet it is true that a struggle maintained patiently to the end of life is the greatest of blessings as secn by faith; nor can we hope for this blessing unless we continually look to Jesus, the Author and Finisher of our faith. Like Him, we must choose the Cross rather than the poisoncus pleasures of the world, despising the contempt of libertines. Let us try to do so quietly, gently, and cheerfully. Why should we be less cheerful than irreligious people, we who have nothing hard to do save with the help of love, and the hope of an eternal Kingdom, while irreligious men have everything to fear and nothing to hope? 
Let us then rejoice in the Lord. . . . Lobos ${ }^{x}$ has many good points. One must wait, and lead him unconsciously; he has a very delicate mouth. Alexis has good sense and feeling, with plenty of good-will. There is stuff in him to make something of: I like him. His brother is a little jealous of a coat I have given Alexis. It is not amiss that the lazy fellow should be piqued, and feel that he is behindhand. He shows some slight desire to apply himself, but the right principle is wanting. We must bring him on as much as we can patiently. ... You, cher Fanfan, must be patient to the end; patient with your pain, patient with remedies, patient with yourself. You must be patient with your own impatience; you must wait, manage yourself, bear with yourself, correct yourself gradually, as you would correct another person whom you want neither to discourage nor to flatter."

I have quoted freely from these family letters, because they bring Fénelon so vividly before one; living his quiet yet active life at Cambrai; surrounded by guests and duties, amid which he finds time to think for every one, from the "little page" Alexis, and his education, upwards; caring so heartily for country, diocese, cathedral, town, relations, friends ;

'Lobos and Alexis were the Marquis's brothers. 
dwelling upon the accidents of his niece's long illness, and the details of his nephew's damaged leg, as though he had no weightier cares to occupy his mind, and turning everything to gold by his instinctive and natural reference to the Love of God. I am the more disposed to do this, as an idea seems to have grown up among some who have spoken or written of Fénelon, that during his latter years he dropped into "a state of passive Quietism," whereas really we need

'Alexander Knox, in his correspondence with Bishop Jebb, runs a fierce tilt against Fénelon, talks of his "spirltual apathy" (vol. i. p. 513), and denounces his "system of devotion as opposite in its leading features to that nature which God has formed us with" (vol. ii. p. 36). But is it needful to defend Fénelon from such accusations to any one who will study his life, even as briefly recorded in this volume, or in his letters? What can be less like spiritual apathy than his earnest teaching to others and his own devout practice?

It seems to me that too much has been made by Père Querbeuf of Voltaire's remarks on a poem of Fénelon's (Siècle de Louis $X I V$. vol. ii. p. 237). Querbeuf assumes that Voltaire "wishes to make out that Fénelon died en philosophe, blindly yielding to destiny, devoid of hope or fear;" but Voltaire's words scarcely imply so much. Nor does the Oa'e sur $l$ Enfance Chrétienne (Euz:res, vol. xi. p. 282) at all necessarily convey a statement of Fénelon's religious belief. The lines,

" Loin de toute espérance

Je vis en pleine paix ;

Je n'ai ni confiance

Ni défiance,

Mais l'intime assurance

Ne meurt jamais," . . . 
only the testimony of his own life and letters to see how very beautiful and zealously active his last days were. If ever any man on the downward course of life threw himself out of himself into the interests of others, their joys and sorrows, or made the deep, fervid love of God, which was as the very air he breathed, take living shape in act and deed, it was surely Fénelon. Quietism, if you please, in so far as he rested with an absolute, unhesitating rest and unquestioning faith in God's Hand, asking nothing save that His Will might be perfected in him, but active and energetic in body, soul, and spirit for his neighbour's good, in prayer, in earnest purpose to the end, as though his whole being were framed upon the promise, "In quietness and confidence shall be your strength." In the technical sense of Quietism, Fénelon's old age was assuredly not that of a Quietist. Let his acts and letters speak for themselves.

if personal at all, would mean that the writer had, as he often said, no hopes or wishes with respect to Court or a restoration to favour. And supposing we choose to take the poem as expressing Fénelon"s own mind, the Réponse condemns the "sotte philosophie," which certainly did not colour Fénelon's declining days. There is an interesting paper by M. de Boulogre, Bishop of Troyes, published in the Fournal des Débats (Oct. 18, 19, 20, 1802) entitled, De la Tcléran:e Philosophique attribuée à Fénelon, in which the Bishop disposes of the question whether Fénelon deserved to be classed with the philosophers, and in the course of which he ailudes to the misconstruction purposely put by Voltaire on the ode referred to. 
The temptation is to transcribe page after page of his almost daily letters to that apple of his eye, the young de Fénelon. One or two more must be granted space :-

$$
\text { “Fuly 3, 1713. }
$$

"Though I write to you daily, très-cher Fanfan, the letters sent by post are not enough. I must tell you by this safe channel how I watch, though not uneasily, for the progress of your cure. Panta is too much engrossed with my health and peace of mind; perhaps I am rather too much engrossed with yours; but really I am fairly at rest, and better than I should have looked for. I shall be better still when you are cured, and I have you in the little grey room beside me. Be sober, patient, resigned to God, and lowly in your griefs. Oh, how foolish one is when one tries to be great! and how good and true when one is content to be in one's own eyes and those of others weak and poor! If you need money, you have only to say so; do not let yourself want for anything. If you are short, it will serve you right; it would be your own fault. Good-bye, très-cher Fanfan. Alexis goes on well, and I like him thoroughly. I don't know whether he will be what is called clever, but he seems to have good sense, good feeling, and good-will. Tout à toi, petit Fanfan." 
"August 5, I713.

"I am counting the days until we meet, but without anxiety or impatience. I may be believed as to my troubles, for I show them enough when I have them, and let my weakness appear. I don't do my own honours well! Continue getting well, without relaxing precautions; don't be shipwrecked just as you are in port, but do whatever your doctors think desirable to hasten and confirm the cure. I will send a carriage Monday or Tuesday next to meet my Godson. ${ }^{x}$ I long to embrace him, and it will be a pleasure, too, to see the little Abbé. . . . Do not be anxious about any really necessary expense. Your father in the flesh is not so really your father as I am, and it is your chief father who will pay whatever the other cannot. As to ces messieurs [the surgeons], I wish to pay them handsomely, but without display;-better to give a little too much, than run the smallest risk in any case of not doing enough, especially in such as this. . . .

"See what books you can bring us. I do not want many; my curiosity is very limited, and I feel that it lessens day by day. . . . I want to send my niece a present as soon as I have a little money to spare. Could you not find out for me what she would like best? Bonsoir, cher petit Fanfan. Give yourself heartily to God, and ask Him to take you in His own s A child of Mme. de Chevry's. 
way, for often one does not know how to give one's self. One is apt to draw back in detail after a wholesale gift, making it an excuse to be really more one's own under pretext of being God's. This is a most dangerous delusion. There is a good rule for donations in the Coutumes, 'Donner et retenir ne vaut."'

\section{"April 29, 1714.}

"Do not be troubled because you said too much. It is enough to perceive simply what has slipped into conversation through self-love. You may tell it quietly to those you trust, out of candour, and as a humiliation, and then let all such details drop, else you will be spinning a perpetual web round and round yourself. . . . Our big Chevalier ${ }^{x}$ started this morning to join you. He struck me as softened, and anxious to do well. God grant that he may conquer his timidity and want of application. . . . Send the little page to me-I insist upon it; he will be no trouble to me now that I am a!most alone. I enjoy my solitude greatly, though the society I have lost is very dear to me."

The Marquis went to Barège for the waters, and the unfailing letters of affectionate chit-chat, mingled with words of counsel, continue. It is pleasant to see

× One of Fénelon's great-nephews. 
how heartily and devotedly the cold-mannered, reserved soldier loved his warm-hearted uncle-how entirely he returned such an affection as does not fall to the lot of every one, and, when it is given, is not always appreciated or returned. How simply and trustfully the young officer must have written of his spiritual life, and his daily needs and faults, the above letters in reply show. It is the same to the last. "Follow freely the plan you wrote to me about in reading Holy Scripture," Fénelon writes to his nephew, June 12, I7 14. "Avoid close application while under treatment. Look at your faults from a simple point of view, without fidgeting, without being discouraged, with a sincere confession of your weakness, and hearty confidence in God, so as to work heartily at your own amendment with the help of His Grace. You shall hear from me twice a week; and if I cannot write, Alexis shall take my place; but I shall give him as few chances as possible. . . Always my dearest Fanfan's unreservedly and for ever."

\section{"July 5th.}

"Be cheerful, gaudete in Domino. Peace and joy in the Holy Spirit are with men of good-will. Detachment sets us free, and spares many a trouble. . . Bear with your distractions and repulsions, without fostering them. Pray with good-will, even if you can- 
not feel much. A servant of God used to say that we serve God with His own wages when we pray with consolation, and that we serve Him at our own cost when we pray in spite of clouds, dryness, and distraction. Your vanity needs to be crushed by neglect and humiliation from within and without. . . . Good night, dearest Fanfan. It is not far from Cambrai to Barège in God-what is one cannot be distant."

In the same way fatherly counsels were continually travelling in kind, playful letters to the young Abbé de Salignac at his college. Some have been already quoted: here is another, dated Jan. 7, I $7 \mathrm{I}_{4}$, just a year before the venerable writer's death:- "I am greatly touched, dear child, by the letter I have just read, shown to me by your brother. I love you from the bottom of my heart, and thank God that you know yourself and mistrust yourself. One is never secure against one's self, save when watching in fear, having constant recourse to God, a heart open to one's real friends, joined with them in striving to correct one's self. You cannot be too careful in following the advice of good friends, or too much on your guard against the example and precepts of worldly friends. What might seem a slight fault in another would be weighty in you. Talk little, and that modestly; 
work diligently. ... Nothing would give me more pleasure than to see you a pious and capable ecclesiastic. I look forward to seeing you next summer."

And a few months later :-

"May 12, 1714.

"I rejoice, dear nephew, to think that the time for seeing you here draws nigh. I look with pleasure to finding you ripened and advancing in your studies. I intreat you to use the remainder of your time diligently. Avoid all dissipation, shun mere amusement, and learn everything accurately. That is the only way to express yourself clearly in few words."

In Fénelon's correspondence with the Abbé de Beaumont, who, it will be remembered, had so long been his constant companion and fellow-labourer, his classical and literary tastes appear more than in any other. De Beaumont was an older man than the other nephews (who were great-nephews, while he was a sister's son); and though to the full as reverential to his uncle, and as ready to accept his fatherly instructions, the well formed and tried character needed not the kindly admonitions and counsels which were obviously not merely accepted, but courted by the younger relatives. Some of the Archbishop's letters to de Beaumont must have recalled memories of days 
long gone by, when the same graceful pen was continually exercised on behalf of the "little Duke." Take as an instance :-

"May 22, 1714.

"Your letter from Cour gladdened me, my dear nephew. Its poetical trifles amused me, and its affection warms my heart. I live solely on affection now, and I shall die of affection. ${ }^{x}$ I only realise spring here in the trees of our poor little garden:

'Jam læto turgent in palmite gemmæ.'

[VIRG. Ecl. vii. v. 48 .]

And in our borders I see the grateful sight:

' Inque novos soles audent se germina tuto

Credere, nec metuit surgentes pampinus austros. . . .

Sed trudit gemmas, et frondes explicat omnes.'

[Geor. 1. ii. v. 332.]

I delight in this delicate touch of the trees:

- Ac dum prima novis adolescit frondibus ætas, Parcendum teneris; et, dum se lætus ad auras Palmes agit, laxis per purum immissus habenis, Ipsa acie nondum falcis tentanda, sed uncis Carpendæ manibus frondes, interque legendæ.'

[lbid. 1. ii. v. 362.$]$

And another exquisite picture :-

I "Je ne vis plus que d'amitié, et c'est l'amitié qui me fera mourir." This was written when one after another of Fénelon's dearest friends had passed before him from this life, and his tender heart, however resigned, was palpitating beneath the shock. 
' Sponte sua quæ se tollunt in luminis oras, Infecunda quidem, sed læta et fortia surgunt.'

[Geor. 1. ii. v. 47.]

This is child's play, which soothes my fancy under our trees. Oh, how I wish you were beneath their shade! But I must be glad that you are at the baths [Bourbon], laying in a stock of health. The Abbé Delagrois reads to me in his room, and chats to me in mine; he is cheerful, has a good heart and a refined mind. You have an immense distance to travel; you will rival the crreurs of Ulysses. I count your steps at my heart's cost. But this absence will bring about the delights of reunion. Get well, pray; be lowly and plastic in God's Hand. Love him who loves you dearly. The dead walnut-trees are a sorrow to me-they were ruris honos."

\section{"June I, I714.}

"You expect tidings from me, and don't give me yours, you very lazy fellow! But I must make excuses for a buveur, who is dispensed from everything except his promenades. I long to know that your course is well over. As to your distant visits, abate your ardour. I only want you to go to Châteaubouchet, Fontaines, and Sainteonge, not to Tulle, Sarlat, or even Manot. . . . Say that I am impatient for

T The Abbé de Beaumont was at the Eaux de Bourbon. 
your return. It is not for nothing that you are grand vicaire.

' Ut mater juvenem, quem Notus invido

Flatu, Carpathii trans maris æquora,

Cunctantem spatio longius annuo

Dulci distinet a domo,

Votis, ominibusque, et precibus vocat,

Curvo nec faciem littore dimovet;

Sic desideriis icta fidelibus,' etc.

[HoR. 1. iv. Ode v.]

Scaliger ${ }^{x}$ is here with his brother. The Sun came by post: ${ }^{2}$ it is very beautiful, and we admire it greatly. Some of us could not tell which was the back and which the front!

'Barbarus has segetes!'-[VIR. Ecl. i. 72.]

Delagrois is still here; he is true, upright, good, noble, pious, cheerful, sharp, and piercing. $\mathrm{He}$ edifies and cheers one, but he is dangerous to people who are not like him."

"June 4, I7I4.

"When shall I hear from you? I long to know how you are getting on. We are well, and at rest.

'Excepto quod non simul esses, cætera læetus.'

You have far to go-

[HoR. i. Ep. x. 50.]

- A nickname for one of the young de Fénelon nephews.

2 This was a massive gold ostensoir, which the Archbishop had presented to the Cathedral of Cambrai. 
'Longa tibi exsilia, et vastum maris æquor arandum.'

[Aneid, ii. 780.]

Do not hurry anything, but don't lose a moment in returning.

'O qui complexus,' etc.-[Hor. Sat. l. i. v. 43.]

The Chevalier des Touches comes on Saturday-

'Mais quelque ami qui vienne, il me manque Calixte, Et moi je ne vois rien, quand je ne le vois pas.'

Take notice that Calixtus is a very venerable name, borne even by several Popes!

"Our lively treasurer has returned out of devotion to the feast of S. Barnabas. Come, dear child, soon, soon. A thousand loves to our relatives." 


\section{CHAPTER VII.}

TO French people, doubtless, the interest of 1 Fénelon's Mémoircs on political subjects is very great: to ourselves they cannot bear any proportion in that respect to his spiritual and friendly correspondence, and I think general readers will not regret it if I pass by the former with little more than an allusion. Fénelon's Mémoires were addressed to his two friends de Beauvilliers and de Chevreuse, for it is needless to say that nothing purporting to come direct from himself had the least chance of being heard by the King or Mme. de Maintenon. Strong good sense, and a very noble, unworldly spirit, such as might be expected from the writer, characterise these documents. In some cases they probably exercised an influence; and had the Duc de Bourgogne lived to wear the crown, this would have been a very vast influence. As it was, they doubtless helped to steer him through the most difficult years of his life. The 
current of this life was about to be changed by events over which neither he nor the Archbishop of Cambrai had any control.

On the I 7 th April I 7 I I, the Emperor Joseph died, without a son, and the succession of the Archduke Charles greatly altered the position of political affairs in Europe. Marlborough's disgrace also had its share in the general colouring of the scene; and to the Duc de Bourgogne himself the most weighty change was wrought by the death of his father, the dull, heavy Dauphin, Bossuet's pupil, who died at Meudon, like the Emperor, of smallpox, only three days earlier. As far as he was himself concerned, few events could have been more unimportant in the world around. ${ }^{x}$ Saint Simon's account of the illness and death, and all the intriguing and manœuvring that were seething round the deathbed, is marvellous. The Duc and

× “. . De caractère, il n'en avait aucun" (Saint Simon, vol. xvii. p. 2). “. . . Il résulte que Monseigneur était sans vice [this certainly was not so!] ni vertu, sans lumières ni connaissances quelconques, radicalement incapable d'en acquérir, très paresseux, sans imagination ni production, sans goût, sans choix, sans discernement, né pour l'ennui qu'il communiquoit aux autres, et pour être une boule roulante au hasard par l'impulsion d'autrui, opiniâtre et petit en tout à l'excès, avec une incroyable facilité à se prévenir et à tout croire, qu'on a vie, livré aux plus pernicieuses mains, incapable d'en sortir ni de s'en apercevoir, absorbé dans sa graisse et dans ses ténèbres, et que, sans avoir aucun volonté de mal faire, il eût été un roi pernicieux."-Ibid. p. 25 . 
Duchesse de Bourgogne were dutiful in their attendance on the sick man. The Duchesse d'Orléans fairly grieved with Saint Simon that the malady seemed to be taking so favourable a turn that they could hope for nothing save recovery. ${ }^{x}$ But apparently the Court physician Fagon had deceived the expectant multitude, or the disease deceived him (Saint Simon says that it was suggested that the Court physicians had no experience in "maladies de venin," and that other advice should be called in; but Fagon was furious, and refused to do so); probably he was really mistaken. The Dauphin began to sink. Some hasty attempt to give spiritual consolation was made, and after an hour of unconscious last agony, he expired. The scenes which followed are graphically described by Saint Simon. The Duc de Bourgogne wept some natural tears for the man who, after all, was his father, though hardly ever bestowing any sign of fatherly affection on his son; the Duchesse, who had been dutiful and amiable towards him, kept up decent appearances. Generally speaking, feeling for him there was none. "Personne n'en fût surpris, et comme il n'y avait plus de Monseigneur, personne aussi n'en fût scandalisé," says Saint Simon. He was buried with scarcely the ordinary decencies, not to

"Mémoires, vol. xvi. c. $26 j$. 
say pomps of the period, so great was the fear of infection. ${ }^{\text {T }}$ The King lay in bed longer than usual the next morning, but beyond that no violent demonstration of sorrow on his part appeared.

Naturally every one began to look on to the time when the Duc de Bourgogne, now Dauphin, would be a worthier successor to the throne than his father could ever have been. To the Dukes de Beauvilliers and Chevreuse a new prospect was opened out. They wisely did all in their power at once to smooth the way between the new Dauphin and his jealous grandfather; and Fénelon, who dared not write directly to his former pupil, addressed him either through one of them, or through Père Martineau, the Duke's Confessor. ${ }^{2}$

"God has brought about a sudden stroke, but His Hand is merciful even amid $H$ is severest dealings. We began with prayer, we pray yet. Death is a grace, inasmuch as it is the end of all temptation. It spares the most formidable of earthly temptations when it takes a prince away before he comes to reign' 'properavit educere illum de medio iniquitatum.'

I "Il fut enseveli, les uns ont dit par des sœurs grises, les autres par les frotteurs du château; . . il fut porté à Saint Denis dans un carosse du roi qui n'avoit rien de deuil ... où tout de suite le corps fut descendu dans le caveau royal, sans aucune sorte de cérémonie."-Vol. xvii. p. 26.

${ }^{2}$ The copy of the letter remains but without address 
Doubtless the sad sight is set before the world to teach men dazzled by the world how really small these princes are who externally seem so great. Happy they who, like Saint Louis, have never used their power for the mere indulgence of self-love, but have counted it as a trust committed to them solely for their people's good. I pray that $\mathrm{He}$ from Whom all wisdom and strength proceed may build the true greatness of . . [ the new Dauphin] on the lowliness of pure grace. Vanity puffs up, without any real dignity; but he who seeks nothing for himself finds all in God, through his own self-abnegation. This is the time for him to make himself loved, feared, respected. $\mathrm{He}$ must strive more and more to please the King; to win him, to make him feel the strength of his attachment, to relieve him by fitting attentions and assiduity. He must become his Majesty's counsellor, the people's father, the comfort of the afflicted, the resource of the poor, the stay of the nation, the defender of the Church, the foe of all novelties. He must distrust and dismiss flatterers; discover merit, seek it out, cherish it, learn to use it; he must lisien to all, believe nothing save on proof, and be as really superior to all as he is in position. He Who gave David a sceptre instead of the crook will give our Prince 'a mouth and wisdom which all his adversaries sha!l not be able to gainsay nor resist' 
(S. Luke xxi. I5), if only he be simple, lowly, recollected, mistrustful of self, trusting in God Only. $\mathrm{He}$ must aim at being a father, not a master; not that the many should be his property, but that he be the property of the many, to the furtherance of their real happiness."

To the Duc de Chevreuse Fénelon wrote a little later (May 12, I 7 I I):- “. . . The P. P. [petit Prince] ought to have himself more in hand than ever, to be open, agreeable, accessible, and sociable. He must undeceive the public as to the scruples imputed to him; he must be careful in his private life, and not frighten the Court with the prospect of a severe reformation which the world could not bear, and which ought, if possible, to be carried on quite insensibly. We shall pray continually for him. I ask that his heart may be as wide as the ocean! $\mathrm{He}$ cannot apply himself too carefully to please the King, to avoid giving him the smallest dissatisfaction, to make him lean upon him in confidence and affection, to relieve him of toil, and to speak to him with a gentle and respectful vigour which will gradually gain strength. $\mathrm{He}$ must only say what can be borne. The way must be prepared before approaching hard and unwonted truths. And as to the rest, let there be no childishness, no religious pettiness. There is

${ }^{x}$ Correspondence, vol. i. p. $45^{2}$.

$2 \mathrm{C}$ 
more to be learnt of government by studying men than books." "

The efforts of the Dauphin's best friends were not unsuccessful. The King was probably ready to be won, and Mme. de Maintenon, to whom the Dauphine was as a daughter, promoted his conquest. The first fortnight, Saint Simon says, testified to every one how great a change had come over the King. ${ }^{2}$ And the same courtier bears witness to the external change which appeared in the Dauphin. "The once timid, shy, self-concentrated Prince, with all his precision, his priggish wisdom, who was as a stranger in his own house, always stiff and constrained, one saw gradually unfolding, giving himself duly to the world, and when in it easy, majestic, cheerful, agreeable, holding his Court at Marly, and presiding like the divinity of a temple, who is sensible to and receives mortal homage as one accustomed to it, repaying men with a graceful gratitude." 3

Saint Simon goes on to describe one who was carrying out to perfection all his great Preceptor's lessons, charming every one by his really intellectual powers, his happily-dropped words of wisdom, wit, or

${ }^{x}$ Correspondence, vol. i. p. 456 .

2 ". . . Un changement si extraordinaire dans le roi, si réservé pour ses enfans légitimes, et si fort roi avec eux."-Vol. xvii. p. 189 .

3 Ibid. p. 190. 
perception, without pedantry or affectation; alike graceful and gracious, paying a seemly and welltimed attention to all whose age, rank, or position deserved it; full of dignified courtesy, unaffectedly grave ("grave, mais sans rides"), yet at the same time cheerful and easy. It was indeed a triumph for the Archbishop; and as the Dauphin's reputation flew on the wings of popular applause, not only over France, but over the world, the world foresaw a triumphant restoration to the Court and to power, and a brilliant worldly and political future for a man yet in his full vigour and charm; while the man himself knelt meekly in his far-distant cathedral, or in his "little grey room," putting up no prayer for worldly greatness, sullied by no thought of self or self-aggrandisement, but crying out in his deep, unselfish love for the lad that was as a son to him :-

"Give the King Thy judgments, O God, and Thy righteousness unto the King's son.

"Then shall he judge Thy people according unto right, and defend the poor.

". . . He shall keep the simple folk by their right, defend the children of the poor, and punish the wrongdoer.

". . . In his time shall the righteous flourish, yea, and abundance of peace, so long as the moon enduretn. ... 
"He shall live, and to him shall be given of the gold of Arabia.... All the heathen shall praise him."

Not for glory in this world were the saintly Prelate's prayers granted, but for how much richer a portion to the child of his love!. But of this hereafter.

It is touching to read in a letter from Lallemant to Fénelon, dated May I7, I7II, "All Paris expects your immediate arrival, Monseigneur. M. le Dauphin asked your return of the King as the one crowning favour which moved him above all else." $x$

The warm-hearted young Prince was no match herein for the cold, jealous, old Monarch, and his request, as might be expected, was not granted; but what did Fénelon care for himself or his own restoration to a favour he knew well how to dispense with, when he saw his "petit Prince" taking his rightful position as a man and a statesman-appreciated, admired, beloved? Truly he had his reward for all he had done and suffered, when the pupil for whom he had toiled and prayed so unremittingly had obtained the affection and esteem of King and country!

Quick as the courtier mind was to perceive the new-born appreciation of Louis XIV. for his grand-

Correspondence, vol. iii. p. 350. 
son, the whole Court was electrified when one day, after a long tête-d-tête, the King gave orders to his ministers to hold their deliberations in the Dauphin's apartment, and to refer everything to him!

"It would be difficult," says Saint Simon, "to describe the prodigious effect on the Court of a mandate so utterly opposed to the mind, inclination, maxims, and customs of the King, hitherto so unalterable, and which for this very reason were tokens of such a confidence in the Dauphin as could do no less than give him the greatest influence over politics." 1

If the Dauphin deserved all credit for his noble bearing under his new circumstances, how much was not owing to the devoted friend, whose admonitions reached him continually through de Beauvilliers and de Chevreuse! Who but one of so large a mind could have written as Fénelon writes to the latter :-

$$
\text { " July 27, } 1711 .
$$

"... I hear that the Dauphin improves greatly. Both his position and his natural temperament set him amid great snares and great resources. That religion which involves him in so much criticism is his only solid support, and if he grasps it largely, without a scrupulous detail, it will fill him with con-

\section{sémcires, vol. xvii. p. 193.}


solation and glory. In God's Name, let him not be governed by you, or by me, or by any one living! Let well-weighed truth and justice rule and decide all he does. He must listen, take counsel, mistrust self, pray to God, and then be as firm as a rock to what his conscience dictates. Let it so be that those who are wrong dread his firmness, and have no hope to influence him save by amendment. Let him be yielding, attentive, easy, comforting, respectful, submissive, full of zeal and of affection to the King, but independent, courageous, and firm, according as the Church and the State have need."

And again :-

$$
\text { "Aug. 24, } 1711 .
$$

". . . I hear that the P. P. goes on improving, that his reputation rises, and that he will carry weight. $\mathrm{He}$ must be upheld, made business-like, taught to see and decide for himself. He must deal freely with men, so as to see through their acts, weigh their talent, and learn how to turn even their failings to good account. He must be put in the way of assisting and relieving the King, and learn to give his counsel in an acceptable way. If he does so earnestly and respectfully, he will not give offence, and will soon be believed. Let him give himself wholly to God, act-

' Correspondence, vol. i. p. $47 \mathrm{I}$. 
ing entirely in His Spirit, and he will have a mouth and a wisdom which the enemy will not be able to gainsay."

Fénelon's correspondence of this period with de Chevreuse is full of suggestions on public matters, and characterises public men and measures with all the skill and perception of a practised diplomatist, as well as the earnestness and unworldliness of what he wasa saintly Prelate. Nothing escapes his loving vigilance : the Dauphin's faults and merits ; his actions, public and private; his friendships, his family duties, suggestions of books he had better read, hints for his conduct to be conveyed best by this or the other of his special friends-all are there, and one is fain sometimes to ask, What would a prince so educated and so counselled have proved himself as a King had it been God's Will that he should ever attain to that perilous grandeur!

That he would do so was the natural expectation of all at his age and that of his grandfather; and in the prospect of the Dauphin's elevation to the throne, who that knew anything at all of the position of things but must have expected too, to see Fénelon second to no one, not even to de Beauvilliers, in the kingdom? The only person who seems never to have thought of Fénelon from a worldly point of view in I Correspondence, vol. i. p. 486. 
connection with the Dauphin's future was Fénelon himself-"you, who never think of yourself," as the Duc de Chevreuse writes to him, Sept. 4, I 7 I r.

The changed tone of the Court, Saint Simon says, made itself strongly felt at Cambrai, which now became apparently the only possible route by which any one could attain Flanders! Every one-courtiers, general officers, soldiers more and less known-every one must needs go that way, and linger as long as possible there. The Archbishop involuntarily held so large and devoted a Court that it needed all his unfeigned modesty and simplicity to avoid serious umbrage being given at Versailles. However, his conduct was so irreproachable in this delicate position, that no sign of displeasure on the part of either the King or Mme. de Maintenon seems to have been betrayed, though they could scarcely be ignorant of the facts. How nicely Fénelon steered between the absolute ignoring of himself for his own sake, and a stedfast putting forward of what in his conscience he believed would promote God's Glory and his country's welfare, was strongly illustrated when, at this very time, he was pressing his views on public matters earnestly upon de Chevreuse. A meeting between them at Chaulnes (one of the Duke's country places), as early as June I 7 I I, was in contemplation, for the purpose of discussing such important subjects; but circumstances 
delayed it till the November following, when Fénelon drew up what he called " a sort of tables of the nature of agenda." Much as these papers tend to prove the thorough grasp he had taken of the whole position and needs of France, they need scarcely be more than mentioned here. His Projet pour le présent goes into the whole question of the peace which he thought a necessity at almost any price; from that he goes on with a plan for reform after peace be made, in which military reform, external policy, Court expenditure, interior administration, religion and Church government, judicature, etc. etc., are briefly, but for the most part vigorously treated.

How far Fénelon's plans for the government of France would have been acted on, or have succeeded, had the young Dauphin ever become King, can only be a matter of speculation. Not a year after the unloved son of Louis XIV. was carried to the grave, the treasured grandson, the nation's hope, was to follow, and the Grand Monarque's declining days were to witness the all but simultaneous death of his heirs in three generations.

It was in the January following upon Monseigneur's death, that, when at Marly, the Dauphine was warned by her chief physician Boudin that there was a design afloat to poison her and her husband. This strange warning was publicly given, en plein salon, and doubt- 
less had much to do with the vehement belief which later on raised so wild a storm, that the death of the young royal couple was caused by poison. No explanations could be given, even to the King himself, who examined Boudin on the subject. Within twenty-four hours the Dauphin received a similar warning from his brother, the young King of Spain, equally vague, though equally confident. The Court affected to pay no heed to such uncertain foretelling; but nevertheless, Saint Simon says that men were uncomfortably impressed by it, and something of a cold shadow and foreboding fell upon them. ${ }^{x}$

At that time the Dauphine was suffering from a swelled face, and soon after feverish symptoms came on, accompanied with severe pain in the head, unrelieved by tobacco smoked and chewed, opium given in quantities, and bleeding twice repeated from the arm ! ${ }^{2}$ Some hope was entertained that the malady was measles, from which many people in Paris and Versailles were suffering; but by Feb. Ioth the doctors decided that the Dauphine's illness was not that epidemic. The Dauphin never left his wife's bedside. Mme. de Maintenon was scarcely a less constant attendant, and the King frequently visited her.

The symptoms became worse, and Mme. de Maintenon suggested to the young Duchess (who always

I Mémoires, vol. xviii. p. I72.

2 1bit. p. 189. 
called her ma tante, and was as a child of her own) that it would be well not to delay the last Sacraments. Her confessor, Père de la Rue, asked if she would like to have some other priest, and after asking Mme. de Maintenon whether it would hurt him should she accept the offer, the Duchess asked for a certain Recollet, the Père Noel, and he spent a long time with her. Extreme Unction and the Viaticum were administered directly after; for the Dauphine grew visibly worse, and the doctors did not know what to make of the malady, which some took to be suppressed smallpox, others malignant fever. The King went to meet the Viaticum, as it was carried from the Chapel of Versailles, his tears flowing fast. $\mathrm{He}$ had by this time forbidden the Dauphin to return to his wife's room, fearing the deadly infection; but it was too late. That was already conveyed; but the Dauphin's pallor, his trembling feverishness and agitation, were naturally attributed to anxiety and distress. The Dauphine received her last Communion, and after a few words of penitence and trust in God, expressed an earnest desire to see her husband. Mme. de Maintenon told her that she had the measles, and that they feared the Dauphin might take it from her. A little later she again asked for him, and soon after, calling the Duchesse de Guiche, said, "Adieu, ma belle Duchesse; I am Dauphine to-day, 
to-morrow nothing!" ("aujourd'hui Dauphine et demain rien !")

Mme. de Guiche expressed a hope that God would restore her in answer to the Dauphin's prayers. "No, He will lay this sorrow on him," she replied, "for He chastens those He loves."

The King remained in the sickroom, giving free vent to his grief. Some one called the Dauphine's attention to him. "If I loved him less, and he loved me less, I should die without a regret," she said. ${ }^{x}$

The seven doctors tried all their remedies-emetics, bleedings, and all the rough treatment in vogue at that time. In the evening of February 12 th the patient became unconscious, and before long expired.

The King and Mme. de Maintenon went that night to Marly, and the next morning, after having communicated, the Dauphin went after them; but he was already very ill; and fainted in the carriage. The previous evening, after being told of his wife's death, he had seen his brother, his confessor, and the Duc de Beauvilliers only, the latter having left his bed to come to his dear Prince, for he was himself ill then. It was the last time they met in this world. Saint Simon saw the Dauphin that morning, and was startled at the alteration in his countenance, noticing, too, certain red livid spots about his face which had

${ }^{2}$ Mémoires de Mine. de Maintenon, vol. r. p. 152. 
appeared also upon the dying Dauphine. ${ }^{x}$ The King made the same observations. . That night burning fever came on,- but there were no malignant symptoms, and the day following the doctors seemed to think rest was all the Dauphin needed, so that the King went to bed comparatively free from anxiety. About eleven, however, the young Prince felt himself much worse, and asked for the Viaticum. His attendants told him that his illness was not dangerous. "I shall be dead," he answered, "before the priest can come." Just at midnight Mass was said in his room," and he communicated with his wonted fervour, and seemed easier in body as well as in mind. But shortly a paroxysm of internal pain came on again, and the Dauphin pressed for Extreme Unction. The attendants were disposed to delay, but he urged them, saying that he should soon be unconscious. Amid frequent ejaculatory prayers his wife's name was continually on his lips. The King was summoned from his bed, only to find his grandson delirious and in convulsions, amid which, about 8.30 , on the morning of February I 8th, he died.

The Dauphin had actually passed away while yet the alarm was so fresh that all Paris was in a state of excitement. Everywhere the churches were crowded

\& Ménoires, vol. xviii. p. 205.

${ }^{2}$ Mémoires de Mme. de Maintenon, vol. v. p. 156. 
with people praying for him, and the relics at Sainte Géneviève were exposed. The tidings of his death following so rapidly on that of his wife almost stunned people. It was a real and universal consternation, Saint Simon says.

There was a pompous lying in state; and on February 22nd the young husband and wife were buried together at Saint Denis. The little Duc de Bretagne, their eldest child, who now at five years old had become Dauphin, remarked to his governess, the Duchesse de Ventadour, that "the journey to Saint Denis was not a pretty one." ${ }^{-}$The little fellow was soon to take it himself. The same malady, whatever it was, which carried off his parents, had already attacked him and his baby brother, the Duc d'Anjou, afterwards Louis XV. The elder boy was bled and physicked, and died March 8th; the younger prince was not yet weaned, and Mme. de Ventadour contrived to save him from medical treatment, otherwise probably he too would have succumbed. He was very ill, though; and when Louis XIV. was told of the elder child's death, he so entirely gave up the baby prince, that he turned to the Duc de Berri, saying, "So no one is left but you!"

The loss was terrible for Louis XIV.; but as a real sorrow of heart probably no one felt it as Fénelon did.

- Mínoires de Mime. de Maintenon, vol. v. p. 158. 
On February I $^{\text {th, he }}$ wrote expressing his exceeding alarm at what he had heard concerning the Dauphin's health; and when the tidings of the Dauphine's death reached him, he wrote to de Beauvilliers as follows :-

$$
\text { "Fib. 18, } 1712 .
$$

"I feel most deeply the loss our P. P. [petit Prince] has undergone, and the keen agony he is bearing. I tremble for his own health, which is fragile and delicate. Nothing can be more precious to the Church, the country, and all our people. I pray and ask prayers for the rest of the Princess's soul, and for the health and consolation of the Prince. You know his temperament-keen, and somewhat melancholy; I dread lest he be overwhelmed with exceeding sorrow, and give way to a grief which might mar his piety with gloom and scrupulosity. We must try to turn these sorrows to account, and stimulate him to a simple, brave devotion, seemly in his position. God is carrying out His own designs; we must follow them. We must sustain, comfort, soothe, and encourage our poor sorrowing Prince."

In the same letter was an inclosure marked "For the Dauphin."

"I pray, and I will pray. I ask prayers for the 3 Correspondence, vol. i. p. 545. 
Princess we have lost, and God knows whether the Prince is forgotten! I fancy that I see him in the state wherein S. Augustine describes himself :- 'Quo dolore contenebratum est cor meum! et quidquid aspiciebam, mors erat. Et erat mihi ... paterna domus mira infelicitas. . . Expetebant eum undique oculi mei, et non dabatur mihi : et oderam omnia quia non haberent eum. Nec mihi jam dicere poterant: ECCE VENIET sicut cum viveret, quando absens erat. . . . Solus fletus erat dulcis mihi, et successerat amico meo in deliciis animi mei. ... Miser eram, et miser est omnis animus vinctus amicitia rerum mortalium; et dilaniatur, cum eas amittit, et tunc sentit miseriam, qua miser est, et antequam amittat eas. . . . Portabam enim conscissam et cruentam animam meam, impatientem a me portari ; et ubi eam ponerem non inveniebam.'

I "At this grief my heart was utterly darkened, and whatever I beheld was death. My native country was a torment to me, and my father's house a strange unhappiness. . . . Mine eyes sought him everywhere, but he was not granted them, and I hated all places, for that they had not him ; nor could they now tell me that 'he is coming,' as when he was alive and absent. . . . Only tears were sweet to me, for they succeeded my friend in the dearest of my affections. ... Wretched I was, and wretched is every soul bound by the friendship of perishable things; he is torn asunder when he loses them, and then he feels the wretchedness which he had ere yet he lost them. ... I bore about a shattered and bleeding soul, impatient of being borne by me, yet where to repose it I found not."-Confessions of $S$. Augustine, Lib. Fath. bk. iv-vii. 
"It is not enough that we love only those whom we may rightly love; our Jealous God will have us love them only for Him and in Him. 'Et ideo,' says S. Augustine, 'non eis amore conglutinetur, neque velut membra animi sui faciat, quod fit amando, ne cum resecari cæperint, eum cruciatu ac tabe fœedent.' All that we love the most lawfully here below does but bring us the keenest grief, inasmuch as it must necessarily be soon taken from us. We cannot love that which is dearest to us more than ourselves, and self may only be loved for God. 'Si ergo teipsum non propter te debes diligere, sed propter illum ubi dilectionis tuæ rectissimus est finis; non succenseat alius homo, si etiam ipsum propter Deum diligis. . . . Nullam vitæ nostræ partem reliquit, quæ vacare debeat, et quasi locum dare ut alia re velit frui ; sed quidquid aliud diligendum venerit in animum, illuc rapiatur, quo totus dilectionis impetus currit. ... Totam sui et illius refert dilectionem, in illam dilectionem Dei, quæ nullum a se rivulum duci extra patitur, cujus derivatione minuatur.' ${ }^{\prime 2}$

s "And, accordingly, let him not be too closely joined to them in love, nor make them as it were members of his own mind, which is the effect of loving, lest, when they begin to be severed from him, they disgrace him with anguish and decline."-De Lib. Arb. lib. i. c. xv.

2 "If then you ought to love yourself, not for your own sake, but for His Sake Who is the most proper object of your love, let 
"God never chastens but in love. $\mathrm{He}$ is the "God of all comfort' (2 Cor. i. 3 ). He dries the tears $\mathrm{He}$ calls forth, and gives back in Himself all that $\mathrm{He}$ seems to take away. He saves her who might have been led astray by worldly prosperity, and loosens his bonds who knew not true detachment. We must give up all to Him in perfect trust, saying, "Thy Will be done on earth, as it is in Heaven.' "'

At the moment these loving lines were written, the young Prince to whom they were addressed was dying; and before they could reach him, he was beyond the power of earthly consolations.

Fénelon's first utterance on receiving the tidings is a wail of intense grief to the Duc de Chevreuse:-

"Feb. 27, 1712.

"Alas! dear Duke, God has cut off all our hopes for our Church and country. He had formed our young

not another man take offence at your loving even him for God's Sake. . . He has left (sc. in 'with all thy heart') no side of our life to be a mere void, and as it were to furnish room to any one to wish for something else; but that whatever else comes into our mind as an object of love should be hurried in that direction whither the entire current of love is impelled. It refers the entire love of self and of another to that love of God which allows no rivulet to be drawn away from itself by the diversion, of which it may suffer diminution."-De Doct. Christ. lib. i. c. xxii.

I Correspondence, vol. i. p. 548 . 
Prince; He trained him, and fitted him for the noblest work. He just let the world see what he was, and now it is over! I am struck down with grief, and the shock has made me ill without any malady. And while weeping sorely for him who is dead, I tremble for the living. My affection alarms me for both you and the dear Duke [de Beauvilliers]. Moreover, I fear for the King, whose preservation is so infinitely important. . . . I hear that the Duchess has been ill, and am very anxious. How closely trial follows upon true affection!"

Not even his private grief could make the Archbishop forget his country's needs, and in the same letter he goes on to say :- " Never was peace so much to be wished for, so necessary. Conceive what it would be if we should be involved in the storms of a minority without any Queen Regent, and with an overwhelming war around. Everything is exhausted and driven to the last extremity. The Huguenots are still formidable, the Jansenists more so than people think. Peace, peace, at any price! Moreover, unfortunately, the King is too old to hope that he will see his successor grow old enough to rule. Even were we so fortunate as to avoid a legal minority,- - that is to say, that the Dauphin were not under fourteen when he succeeded,-there is no hope of escaping

'Correspondence, vol. i. p. 550. 
a practical minority, in which the child's name will be merely a tool to the strongest party. There is no sure remedy for this evil. All that human prudence can hope to do, is without loss of time to establish such a government and plan of education for the little Prince as may be firmly assured should we lose the King. His honour and glory, his love for the royal family and for his people, and moreover his conscience, demand most rigorously that he take every precaution human wisdom can suggest in this matter. It would be exposing the State and the Church alike to the most fearful peril not to give heed to this capital point before all else. You must try to do all that is possible to unite Mme. de Maintenon and all the ministers in making every effort to influence the King. The Father Confessor [Le Tellier] ought to take his full part, in the very obvious interests of religion. I could say a great deal on this subject, but you know it all still better than I do, and I have neither time nor strength. I pray our Lord to inspire you : never were we in so great a need."

The need was great indeed, and Fénelon felt, with the instincts of affection, that those he most trusted in that hour were passing away. The Duc de Beauvilliers was already ill when the Dauphin died, and a letter to the Duc de Chaulnes (formerly the Vidâme d'Amiens, now the eldest surviving son of the 
Duc de Chevreuse), dated March 4, I 7 I $2,{ }^{x}$ shows how much anxiety there was for his health also. But a few days later Fénelon was writing urgently to him about public matters. ". . . I would give my life," he says, " not only for the State, but for the children of our dear Prince, who is still nearer my heart now than when living. . . . I should say that the dear Duke [de Beauvilliers] would do well to go and see Mme. de Maintenon, and speak openly to her, regardless of past coldness between them. $\mathrm{He}$ should make her feel that it is not a question of interest, direct or indirect, but of the security of the State, the peace and preservation of the King, his glory and his conscience, for the sake of all which he ought as far as possible to make provision for the future. He should further tell her his own chief ideas, and in concert with her decide what to lay before the King." 2

It was not unnaturally a subject of some anxiety at this moment to all the late Dauphin's special friends what might become of his papers, and how far any of these might give offence to the King,- not probably from their contents, for assuredly neither the Archbishop nor the Dukes had ever written one disloyal word, nor one of which they could be ashamed, but owing to his own jealousy and unwillingness that his 
grandson should be counselled by any hidden under a cloud from the royal favour. The Dauphin's cassette, or despatch-box, was demanded immediately after his death; but while sending the key to his Majesty, de Beauvilliers determined to trust the precious box to no one, and waited till he was sufficiently well himself to take it to the King. Saint Simon says that the upper part of the cassette was happily filled with a fatras of all manner of mémoires and financial projects, a number of which de Beauvilliers read to the King, until he became so tired, that, assuming all the contents to be equally uninteresting, he bade the Duke burn them all, which was done, save and except certain papers which the Duke dextrously withdrew. ${ }^{x}$ This, however, does not seem consistent with a note to de Beauvilliers from Mme. de Maintenon, dated Saint Cyr, March 15, I 7 12, saying,- "In order to set your mind at rest, Monsieur, I have made copies of all your writings, and send them to you all without exception. Your secret would have been kept, but there are occasions which disclose everything; we have made sad experience of it. I wanted to send you everything that was found of yours or M. de Cambrai's, but the King chose to burn them himself. I confess that I regretted it much, for nothing so good or so admirable will ever be written again; and

- Mémoires, vol. xviii. p. 25 I. 
if the Prince we lament had some failings, it is not owing to his having been timidly counselled or flattered. It may be affirmed that those who go straight forward are never put to confusion."

Among these papers Fénelon supposed one would be found which the King might choose to be offended at, entitled "Directions pour la Conscience d'un Roi," -which, written as it was solely for the spiritual guidance of the Dauphin, could hardly be said to be a representation of his grandfather's conduct; although pomp, display, a disproportionate love of glory and ambition, unjust acquisition, the taste for flattery, and the like, were therein deprecated in a manner which Louis XIV. might have thought personal. But the young Dauphin had guarded against anything of this sort which might have aggravated the injustice already done to his beloved Preceptor; he had burnt or committed to de Beauvilliers' care all such papers as he conceived likely to displease his grandfather should they fall into his hands; and the manuscript in question remained in Mme. de Beauvilliers' hands after her husband's death, until she gave it ultimately to the Marquis de Fénelon, who published it in the year $1734 .^{2}$

These were heavy days to Fénelon : his heart was sad at the prospects which seemed to threaten his

I Correspondenie, vol. i. p. 556.

${ }^{2}$ Euvres, vol. ix. p. 373. 
country, and he was worn with toil, anxiety, and care. A few touching lines written to the late Dauphin's Confessor, the Père Martineau (who had asked him for his recollections of the Prince with a view to a life the Jesuit Father was about to write), set this vividly before us :-

$$
\text { "April 3, } 1712 .
$$

"I will frankly confess my weakness, mon Père ; I do not feel able at present to look up the facts you want put together. I cannot say too much for your zeal and goodness, but I have not courage to carry out a work I so heartily desire to see done. The sorrow which has come upon us has taken such hold upon me that my health has suffered considerably, and whatever revives my grief brings on a certain amount of feverish agitation. I must wait till rest and contemplation of God calm my mind, although I am humbled by my weakness. M. de Beauvilliers can help you much better than I could; his advice will be good, both as to furnishing facts, their selection, and the best way of using them. You will easily perceive that there is much to consider on this score-

$$
\begin{aligned}
& \text { "Periculosæ plenum opus aleæ } \\
& \text { Tractas."-[HoR. Carm. lib. ii. i. 6.] }
\end{aligned}
$$

You know the world, and the malice of its criticism. As soon as my head is somewhat stronger I will try 
to do what you wish. Meanwhile I ask your prayers, and remain," etc. ${ }^{x}$

I have purposely not dwelt upon Fénelon's political papers, but some allusion can hardly be omitted to one which he saw fit to draw up at this period with regard to the Duke of Orléans. Remembering the warnings about poison given to the Dauphin, together with the rapid death of himself, his wife, and child, the second child suffering from the same malady, a malady which baffled the physicians either to treat or to name, it was scarcely strange that early in the eighteenth century such startling events should be attributed to crime rather than to natural disease, and the public voice very generally cried out that the Duke of Orléans was the murderer of his cousins. Fénelon was not prejudiced against the Duke, rather the contrary; yet so strong were the possibilities, that he felt bound to write as though he were guilty, and to consider all the difficulties of a public inquiry into the facts, while he believed it necessary to make private inquiries for the protection of the infant Dauphin, whose fate must probably ere long depend upon the Duke of Orléans as Regent. Fénelon not unnaturally felt that a man who was so notorious an unbeliever, and of so profligate a life,

- Correspondence, vol. iii. p. 5 II. 
laid himself open to any imputations. It is due to the Duke's memory to say that Fénelon ended by believing him entirely innocent of the dark deeds thus attributed to him. It was after this that a lengthy correspondence took place between them, the Duke laying before Fénelon his so-called philosophic doubts respecting the existence of God, the immortality of the soul, free-will, etc. ${ }^{x}$ The substance of Fénelon's arguments will be found in his "Treatise on the Existence of God," 2 only part of which was published during his life, and much of which has been considered by able judges as a masterpiece both of philosophy and literature.

Another call upon Fénelon's powers of teaching was made by a Scotchman named Ramsay, who, sickened by the Protestantism in which he had grown up in his own country, revolted, as he says himself, ${ }^{3}$ against the fanaticism and inconsistency which he met with in "all Christian sects;"-and he wandered over all Holland and Germany, hoping to rest amid the philosophers of those countries. Yet he could not swallow the monstrosities of atheism, and thought to find a refuge in deism. But "it seemed a bold measure to plunge into that, while to stop short in any Christian sect appeared childish weakness. I

× Euvres, vol. ii. p. 317 . 2 Vol. ii.

3 Entretiens de M. de Ramsai.-Euvvres, vol. iii. 
was tossed hither and thither amid the vague ideas of ultra-toleration, unable to find a resting-place, and in this mind I reached Cambrai, where the Archbishop received me with his wonted fatherly, attractive kindness, which at once won my heart, and during the next six months I went with him into a very careful study of religion."

Ramsay (de Ramsai he is generally called) has left an interesting record of his intercourse with Fénelon, which will scarcely bear condensing. Suffice it that the dry Scotchman was wholly won, as much seemingly by the personal holiness and dailywatched beauty of the Archbishop's life, as by his clear and helpful teaching; and one is not surprised to hear that Andrew Ramsay found a refuge from Calvinism, philosophy (so-called), and deism, in the Catholic Faith. He continued much at Cambrai, never weary of studying his host's mind and life, and eventually he wrote the first Life ever published of Fénelon. Subsequently Ramsay became tutor to some of the Pretender's family; and there is an interesting story on record, telling how the friendship of Feénelon stood him in stead at Oxford years after. In 1730 Ramsay came to England under a safeconduct, and was received as a member of the Royal Institution on the strength of his connection with the Archbishop of Cambrai. He further de 
sired to take a doctor's degree at Oxford, and the Earl of Arran, then Chancellor of the University, proposed him for that honour, when an opposition was raised in Convocation on the double ground that Ramsay was a Roman Catholic and had been a servant of the Pretender. Dr. King, Head of S. Mary Hall, then spoke, summing up his defence of Ramsay with the words, "Quod instar omnium est, Fénelonii magni archi-præsulis Cameracensis alumnum præsento vobis," and carried his audience with him so entirely on that ground, that Ramsay was admitted to his degree by a majority of eighty-five to seventeen votes.

Fénelon's large correspondence, many volumes of which are preserved, embraced a number of the eminent men of his day. Père Lami, a learned Benedictine, the controversialist of Malebranche, was one of these ; $^{x}$ Cardinal Quirini ${ }^{2}$ another; while Marshal Munich, who had spent some time at Cambrai as a prisoner of war, and the Chevalier de Saint George (generally called James III. of England in his own circle), were no less devoted to the Archbishop in their respective lines. ${ }^{3}$

${ }^{x}$ See Correspondence, vols. ii. iii. vii. ix. ${ }^{2}$ Ibid. vols. iii. iv.

3 The Marshal never could speak with sufficient admiration and reverence of Fénelon to the end of his days; and at the Court of St. Petersburg, in his Crimean campaigns, during his twenty years' exile in Siberia, or the dignities of his latter days, 
The Cas de conscience, ${ }^{\mathrm{x}}$ which formed so marked a feature in the Jansenist controversy of Fénelon's time, led to his writing at some length on the subject, in the shape of pastoral letters, etc. Louis XIV. hated the Jansenists, and it was at his request that Pope Clement XI. put forth the celebrated Bull of I705, known as "Vineam Domini Sabaoth." " In the disputes which followed this in the Assembly of Clergy, Cardinal de Noailles attacked Fénelon in a way which delicacy might have forbidden after their former passages, both of friendship and opposition. Much of the discussion and contest that went on then turned upon mere verbal and grammatical questions, which are hardly of sufficient general interest to be entered upon here. It was after the assembly that Fénelon put forth a pastoral in the form of dialogues concerning some of the great controversies which had troubled the Church.

he alike loved to dwell upon the long-past time when it had been his privilege to know that venerable man, and to share in the charms of his intercourse. If the immediate ancestors of the Chevalier de Saint George had had as healthy counsel as that which Fénelon gave their descendant when he visited Cambrai, and discussed politics with him, they might not have lost their throne.

"See Bossuet and his Contemporaries, p. 548.

2 The history of this Bull, all that led to it, and the curious manœuvring and mystifications which went on at the time of its publication, will be found in d'Aguesseau's Mémoires sutr les Affaires de l'Egglise de France. - Euvres, vol. viii. p. 223, etc. 
We may be excused for passing over the details concerning Quesnel's Réflexions Morales, and the Cardinal de Noailles' disgrace. Many of Fénelon's letters to de Chevreuse turn on these topics, but they do not sufficiently touch his personal history, anc their chief interest is too much past to make it seem well to enter upon the subject here.

Fénelon's life was drawing to a close, and the many sorrows which fell upon him doubtless told upon a constitution enfeebled by hard work and spare living. Before the Dauphin's death he had lost his dear friend de Langeron, who died at Cambrai, Nov. 10, I 7 10. Fénelon's letters are full of allusions to him during his illness. "Oh, how full of sorrow life is ! God Alone is loving amid His severity," he writes to de Chevreuse, announcing the Abbés illness; and on his death, "I have lost the greatest comfort of my life (la plus grande douceur de ma vie), and the best helper God has given me in the service of His Church."x And to Père Lami: "I have lost a friend who has been the delight of my life for thirty-four years. He died of fever, which at first seemed hardly more than a passing indisposition. . . . He faced death, giving himself up to God with a peace which seemed to flow from the One true Source. He was as obedient as a little child; and even when he wandered, his very

'Corresfondicnce, vol. i. p. 422. 
wanderings were devout-all sprang from the deep root of grace and detachment. The more I was edified, so much the more was I touched, and I must confess that $I$ have been very weak in my sadness. I am now in a state of calm sorrow, with a tender remembrance which often renews my grief, but my health is good." 1

A touching letter, written on the 17 th Jan. I I I , shows how the sorrow was still telling, in spite of Fénelon's submissive heart :-

"I have not the moral strength you imagine. I have felt my irreparable loss with a keenness which shows how weak my heart is. Now my imagination is somewhat quieted, and there only remains some sadness and a kind of interior languor. But the softening of my grief humbles me as much as itself did, for all that I have felt in both conditions has been altogether from imagination and self-love. I confess that it was for myself I mourned in mourning a friend who was the delight of my life, and whose loss I feel at every moment. I am conforted, as I was afflicted, by my weariness of grief and the need of consolation. Imagination, which was overwhelmed by the first unexpected grip of sorrow, has grown used to it, and is calmed. Alas! all in us is vanity, except that death to self which is the work of grace. ${ }^{x}$ Correspondence, vol. iii. p. 283 . 
Moreover, my dear friend died with so simple and trustful a looking to his end as would have delighted you. ... I never saw anything more edifying or loveable. I tell you this that I may not set my sorrow before you without also setting forth that 'joy of faith' of which S. Augustine speaks, and which God has given me to feel on this occasion. God has worked His Will. $\mathrm{He}$ chose to seek my friend's happiness rather than my comfort; and I should be wanting alike to God and to my friend if $I$ did not will what $\mathrm{He}$ wills. In the sharpest moment of my grief I offercd up him I so dreaded to lose. . . . "

These repeated wounds were yet fresh when the Duc de Chevreuse was taken from his family and friends, Nov. 5, $\mathrm{x} 7 \mathrm{x} 2$. "I cannot grow accustomed to our irreparable loss; I shall feel it bitterly as long as I live," he writes on the 28 th Nov. to the Duc de Chaulnes ; ${ }^{2}$ and on Christmas Day Fénelon says to de Beauvilliers, after imploring him to take care of his failing health, to go out riding, and to get what rest he can for his mind:- "May God preserve you, and enlarge your heart through simplicity and selfrenunciation, which will ever promote your health. What would I not give for your preservation! My heart has been sore ever since the irreparable loss of the "petit Prince;" and that of the cher tuteur has

${ }^{*}$ Correspondence, vol. v. p. 385 .

2 1bid. vol. i. p. 57 i. 
opened all my wounds afresh. But God be praised; be it ours to adore His impenetrable purposes." :

"Let us unite our hearts to him we mourn," he writes to the widowed Duchess. " $\mathrm{He}$ is not gone from us, because invisible; he sees us, loves us, feels our needs. Happily in port himself, he prays for us who are still exposed to shipwreck. He is for ever calling us with an inner voice to hasten after him. All pure spirits see, hear, and love their true friends in their common Centre. ${ }^{2}$ Their friendship is as immortal as its Source. Unbelievers love nought save themselves, and they may well be in despair at the loss of friends; but a holy friendship only changes visible companionship for that of faith: it weeps, but

Correspondence, vol. i. p. 575 .

${ }^{2}$ Dr. Newman might have read these words before writing his exquisite poem, the comfort of so many mourners :-

"I still am near;

Watching the smiles I prized on earth,

Your converse mild, your blameless mirth;

Now, too, I hear

Of whispered sounds the tale complete,

Low prayers, and musings sweet.

A sea before

The Throne is spread; its pure, still glass

Pictures all earth-scenes as they pass.

We, on its shore,

Share in the bosom of our rest-

God's knowledge, and are blest."-Lyra Apostolica. 
amid tears it is comforted by the hope of rejoining our beloved ones in the abode of truth, in the very Bosom of Love itself."

Fénelon's letters at this period are full of tender anxiety about Mme. de Chevreuse, who had always been one of his most valued friends; earnest advice that she should not let herself be overpressed and smothered in the secular business which the death of her husband brought upon her, and friendly counsels to her son the Duc de Chaulnes. The measure of Fénelon's friendship with such persons, men of the world, living amid the stir of politics and Court, may be taken by the unhesitating manner in whichevidently certain of being understood and acceptedhe lets drop a few words bearing on their higher spiritual life, amid wonderfully practical and sensible advice as to temporal things. Thus he writes to the Duc de Chaulnes:- “For God's sake, dear Duke, don't drown yourself in details and innumerable letters. Get help, deçide, act promptly, and keep time for yourself in which to learn how you can best act in important matters. Attend to all bienséances, make suitable acquaintances, fulfil the callings of your rank; but nevertheless be recollected, detached, faithful to God. You owe yourself to the public welfare under the conditions which threaten us; prepare for its service by studying the things you 
ought to know, and the connections you ought to make; do all quietly, in a spirit of faith, and without ambition. . . . Reserve free times for prayer, reading, interior nourishment, and also for the claims of your position, the study of history, general affairs, and whatever will make you most useful in your day. A man of your rank is not doing enough, but falls short in his service to God, if he is absorbed only in technicalities, collecting curiosities, arranging papers, details of a regiment or an estate. You owe yourself to your King and your country, and, ambition apart, you ought to fit yourself to promote the public good. ... Detail is your snare, beware of it. Pray, read, and learn. See your fellow-men, and be seen of them; fulfil your vocation,-mine is to torment you! I love you so dearly, and I want to see you moulded by God's Hand to His work." "

In the spirit of the Wise Man's precept for keeping up old friendships, Fénelon extended his warmhearted interest to de Chrevreuse's grandchildren, and in the last summer of his life pressed to have the Duc de Chaulnes' young children with him at Cambrai:-

"Don't forget that you have promised me the dear little ones when the warm weather comes. ... I want your children, who are mine too, about Whitsun× Correspondence, vol. i. pp. $578,580,583$. 
tide, when I shall have returned from my visitation. They will not be in the least in my way; and I shall be head tutor over M. Gallet, and you may rely on it, you will get no compliments from me!"

The children paid their promised visit, and the Archbishop writes to their father with discriminating interest about them:-

"The Vidame ${ }^{\mathrm{x}}$ is forward as to sense, firmness, decision, and clearness, and I think he is acquiring great command over his temper. He is softening, he wishes to please; sees his faults, acknowledges them heartily, and is fond of those who reprove him gently: $\mathrm{He}$ is rough and harsh, but, considering his age, he tries hard to correct that. $\mathrm{He}$ is courageous, practical, feeling, and has a religious mind. $\mathrm{He}$ is a very nice child, and fills one with the best hopes.

"De Piquigny is clever, bold, and chatters readily, but his temper is strong, and he is not yet reasonable enough to control it. $\mathrm{He}$ is vehement, and is not easily called to order, but there is so much character and sense at bottom, that one may look for great things in him. He needs to be managed with gentle,

I The Vidame d'Amiens was the eldest boy, then nine years old, the Comte de Piquigny seven. The Comte de Montfort was a nephew of the Duc de Chevreuse, then eleven. He became Archbishop of Sens in after life, and died a Cardinal in 1788. 
patient, steady firmness. He must be corrected from time to time, or he would behave very badly to his brother, whom he sometimes strikes so as really to hurt him. And it is not easy to make him feel that he is wrong; he hardens himself, and treats correction with contempt: but if he be trained gradually to selfcontrol, the child's fine qualities will develop. It is a very strong character naturally, and the only thing is to temper and soften it. As he grows older, and his reason stronger, instruction, authority, example, will all mould and repress his childish impetuosity. ... De Montfort is good, reasonable, and open to religious feeling, though somewhat frivolous and inattentive through his love of play. But he is full of grace, and I trust God will mould him to an ecclesiastical vocation. If he were a little older, or I younger, I should have designs upon him for the future: I love him dearly. ... I am delighted to have the little troop; they cheer me up, and are not in the least in my way. Even if I have to go away on visitation, they will go on just as if they were at Chaulnes; the house goes on in its usual routine,--I should not be long away, and charmed to find them on my return. If you think I can be of any use to them, make use of me in all sincerity. . . . I am anxious about your health. Do not wear yourself out with petty details and superfluous precision. 
True precision consists in never neglecting important things, but it is a mistake to get behindhand in great matters out of a taste for trifles. If you give yourself up to trivialities from choice and taste, it is a great mistake as regards worldly wisdom; and if you do it to please God, and with a view to your duty, you will fall short by dint of wishing to be lacking in nothing. God does not require a false exactitude which pays such a superstitious reverence to trifles that it quite loses sight of what is essential. Do those important duties which you cannot rightly make over to any inferior, but do not worry yourself with things which you can perfectly intrust to others who will be responsible to you. He who does not know how to relieve himself, by making others work under him, does not really know how to work! The first duty of one in a superior position is to assign everybody's task, to keep the whole thing going, and quietly to direct others' work. . . . You must strive to be as a man who reads God's Will in a book all day long, and goes on pursuing it without harass or anxiety. . . . It is self-will which makes one stiff, confused, and disheartened, which makes one never have time for anything." $x$

The children remained through the autumn at Cambrai, and the Archbishop's letters to their father

${ }^{x}$ Correspondence, vol. i. p. 587. 
and mother and the Duchesse de Chevreuse are full of little remarks about them, which prove the genuine affection and the keen eye with which he watched them, as he had watched their father, to whom a great number of letters were addressed in his earlier life, which will be found among the Spiritual Letters. Almost to his very last days Fénelon wrote such letters of affectionate counsel and warning to the Duc de Chaulnes. "See how your lively old friend writes," he says playfully (Nov. 23, I 7 i4), "of the briefest and most trenchant! He is stingy of words, and cannot pause in his course ! . . . You will say I am a rough customer! Yes indeed, I shall scold on for very love's sake, until I see you in your proper place, doing what God would have you."

It was during this autumn that another, not unexpected blow fell, and Fénelon lost the last of that special group of friends who had "stuck" to him "more closely than brothers." De Beauvilliers died August 3 I, I 7 I 4. It was a heavy trial, and Fénelon felt the separation not the less keenly that they had never met again since he left Versailles so hurriedly in consequence of what was the King's virtual act of banishment. "Our best friends," he wrote under his first grief, "are the source of our greatest sorrow and bitterness. One is tempted to wish that all great Correspondencc, vol. i. p. 597 . 
friends could wait and die on the same day. People who love no one would be content to bury the whole human race with calm satisfaction and dry eyes-they are not worthy to live! Strong friendship costs a heavy price; but those who know its joys would not give it up, they would far rather suffer than be callous."

"I only live on friendship now," he wrote to the Abbé de Beaumont in May, " and friendship will be the cause of my death;" and a little later: "I know how dearly I love you, and that is what frightens me, for God takes away all those I love best. I must love them amiss, since God's Mercy or His Jealousy sees need to deprive me of them." 2

The Duchesse de Beauvilliers had been as devoted a friend as her husband, and whatever tender sympathy and fellow-feeling could do to comfort her in her sorrow Fénelon did. "The hope you give me of being of use to you, madame," he writes (Nov. 16, I 7 I4), " is one of the greatest consolations I can have for the rest of my life. Meanwhile, I pray God daily to comfort you. There is a comfort which our hearts reject, and rightly; for it is hollow, and unworthy the Spirit of Grace. But there is another comfort which comes from God Only: He satisfies the cravings of desolation; He makes us feel that we have really lost nothing, and that we may find again in Him all we

× Correspondence, vol. ii. p. 247 .

2 Ibid. p. 270. 
think to have lost; He brings our lost back to us in faith and love; $\mathrm{He}$ shows us how closely we are following those who have left us; He dries our tears with His own Hand. I trust that $\mathrm{He}$ Who has laid this crushing sorrow on you will still your agony; none save $\mathrm{He}$ can do it. Take care of your health, which must have suffered with all that you have undergone." $x$

Closely indeed the venerable Archbishop was following the dear friends who had left him! The atmosphere of another world was becoming more and more that in which he lived; very gently and imperceptibly the mortal was making ready to put on immortality. His bodily health had for some time caused anxiety to his family, although he was, as he tells the Marquis de Fénelon (May I4, I 7 13), " good and obedient, setting a good example to my children. I began yesterday to take my milk; I go out walking, and I am lessening my work." = And-"I go on with my milk: I amuse myself-it is a sort of second childhood. God grant us the childlikeness Jesus Christ has taught us so earnestly !" 3

In the summer of I 7 I 4 he spoke of himself as passing his days without weariness, and finding time all too short for his occupations; adding, that could he but see

Correspondence, vol. i. p. 595. 2 Ibid. vol. ii. p. 209. 
a few absent dear ones, his desires would be perfectly fulfilled; and concluding, "But I am at rest, and satisfied with my daily bread." " At this time, when his head and heart were both full of private sorrows and public cares, he could take the liveliest interest in a visit paid by his nephew, the young Marquis, to his old home at Fénelon, and in the wellbeing of his old nurse. It was only the day before de Beauvilliers' death that he wrote:- " Do not be anxious about me. I am sad, but at peace, and in full submission to God. Men suffer greatly through imagination. The heavy sorrows which we see coming grow familiar by degrees. Our suffering is protracted, but the actual blow is less severe, because it does not take us by surprise. I suffer now in calm languor, not with violence." ${ }^{2}$ And (Oct. 4, I 7 r 4) :- "My health is not amiss, in spite of the sorrow of mind and toil of body which $I$ have lately undergone."

Public events were still of a vivid interest to him, in so far as they affected his country and the Church, or any of the claims of duty, which he fulfilled as diligently as he pressed them on others; but the matters which really touched Fénelon's heart now, as he drew nearer and nearer the border lands, were connected with his friends and those he loved. Yet not even for them would he in the smallest degree depart

${ }^{2}$ Correspondence, vol. ii. p. 260.

2 Ibid. p. 266. 
from the line he had laid down for himself; and when Mme. de Chevry (the sister of de Beaumont, to whose illness repeated allusions have been made in letters quoted already) was supposed to be dying, and caused an effort to be made with a view to her uncle being permitted to come and see her before she died, he felt it necessary steadily to explain that any such efforts had been made without his consent or knowledge. There is great dignity in the letter which Fénelon wrote on this occasion to the Secretary of State, Voysin :-

"I have just learnt that some one unknown to me wrote lately to you intreating you to intercede with the King that I might be allowed to go to Paris to see a niece who is dangerously ill. I can quite understand that I may not be believed when I say that I knew nothing at all of this request, which I should have endeavoured to prevent had I been told it was going to be made. It may even be supposed that I disavow it now only because it failed : but it matters not what is thought of me. God knows all these manœuvres are not my way of action. And moreover, sir, I may presume to say that my conduct has not borne tokens of such indiscreet eagerness. I know, thank God, how to remain at peace and in silence, without attempting any such ill-advised steps. No one ever felt a livelier gratitude for the King's favours, a deeper 
respect, or more inviolable attachment to his person, or more ardent zeal for his service; but no one could be further than I from worldly anxiety or aspirations. I daily pray to God for his Majesty's precious life; I would willingly sacrifice my own for him. What would I not do to please him! But I have neither inclination nor intention of drawing nearer to the world. I have no object now save to prepare for death, striving meanwhile to serve God's Church so long as I live in the place where I am. Meanwhile, sir, I do not take the liberty of saying thus much to you with any desire that you should of your kindness use it on my behalf at Court. You can altogether suppress it if you think fit. There is nothing in this world which I desire more earnestly than to fulfil my every duty towards his Majesty with unalterable zeal; I have never wavered in this desire, but it is no human interest which kindles it. I rest content with past kindness, without seeking any possible favours from the future, and am, with sincere devotion," etc. etc. ${ }^{\text {I }}$

The Archbishop was conscious of failing powers all through that year; indeed, from the period of the Duc de Bourgogne's death he never regained physical strength or vigour, and, unable to bear that his diocese should suffer, he greatly desired a coadjutor. October 14, I7I4, he writes to de Beaumont:I Correspondience, vol. iv. p. 324 . 
"See Père Le Tellier [the King's Confessor], and discuss the question of a good coadjutor with him. It would be an infinite gain to the diocese, and a relief to me, which I need beyond belief. Moreover, it is a need which will increase daily. Consult also with Pères Germon and Lallemant, under promise of strict silence." \& And, November 26 th following : - ". . . It would be well for you to see Père Le Tellier, and talk to him about my sincere desire for a coadjutor: I really need one. But you must make it clearly understood that I would rather resign and have a successor appointed, than accept a coadjutor whom I did not know thoroughly by the test of his working some time with me. It is a hard test, and necessarily must delay the result for some time. As to resignation, the stormy times we live in now make me unwilling to choose that course, and those which lie before us are scarcely likely to make it easier. I should like to know the names of such men as Père Le Tellier and Lallemant would suggest for the coadjutorship.... If the Archbishop of Sens dies, I should be inclined to try and get the Bishop of Waterford, ${ }^{2}$ who is now helping him, to come and

I Correspondence, vol. ii. p. 268.

2 An Irish Bishop, driven from his country by the evil times. The Archbishop of Sens-Hardouin Fortin de la Hoguettesurvived Fénelon some nine months. 
help me. I am almost killed with my innumerable confirmations. . . The National Council may come to nothing; but if it is held, and I should be regularly summoned, like everybody else, what ought I to do? I should be very much distressed at being called upon to be one of the executioners of a man who executed me as far as he was able. It would seem like taking vengeance, and would put me in a very odious position. On the other hand, I owe everything to the Church in an urgent time of need. If I could be sure that all would go smoothly, I should be very glad to take no part. But if the Council were to be in real danger of division and difficulty, in which I might be not altogether useless, I would sacrifice myself, supposing I were really wished for, and then I should return here by the most direct route. Discuss this with the very few in whom we have perfect confidence. I, for my part, will earnestly ask God's Guidance." x

The coadjutorship never came to pass; but it is characteristic of Fénelon that he never seems to have thought for one moment of choosing any one of his own family or immediate friends for the office. Cardinal de Bausset says he had decided upon a young Abbé de Tavanes, who later on became Bishop of Châlons, and eventually Cardinal Archbishop of × Correspondence, vol. ii. p. 27 I. 
Rouen. ${ }^{x}$ The whole matter was kept in such silence, that de Tavanes himself did not know of the selection so much to his honour until many years after, when he found allusion made to it in a sketch published by the Marquis de Fénelon of his uncle's life (I 734).

The Council, or Assembly of Clergy, to which Fénelon alludes as possibly obliging him in conscience to leave his exile for the first time, was held in connection with the Bull Unigenitus, which was promulgated, September I 7 I3, by Pope Clement XI., condemning one hundred and one propositions taken from Quesnel's book on the New Testament, which Cardinal de Noailles had approved, and he steadily persisted in refusing to recall his approbation. The King called together the National Ecclesiastical Assembly to examine and accept this Bull, which was universally considered as a practical condemnation of the Cardinal Archbishop's action with respect to Quesnel's book. A commission was appointed to examine into the question, consisting of the Cardinal de Rohan, the Archbishops of Bordeaux and Auch, and the Bishops of Soissons, Meaux, and Blois. After three months' close consideration, they unanimously pronounced that the Bull confirmed the Church's true doctrine, and that the National Church could but accept it respectfully. Cardinal de Noailles only, with

'Histoire de Fénelon, vol. iv. p. 244. 
a following of eight Bishops, dissented, and declined to accept the Bull, which was formally accepted by the rest of the Assembly, February 14, 1714, confirmed by the King's letters patent, and registered by Parliament the next day. Those who wish to study the ecclesiastical politics of this period in France, will find them fully and amply discussed in the Chancellor d'Aguesseau's writings (vol. viii.). Suffice it to say here, that it was to the implied condemnation of de Noailles (who had been one of his chief prosecutors) that Fénelon alludes in the letter quoted above, when objecting to appear at the Assembly unless imperatively called by duty. He put forth two mandements on the subject of the Bull, besides several mémoires on the subject, and a voluminous correspondence, which can only be alluded to here. ${ }^{x}$

This was Fénelon's last public exercise of his archiepiscopal office, excepting, indeed, local ministrations, which he continued to the very last, and that far beyond his strength. The Abbé Galet says that in the last visitation Fénelon made he was so exhausted that he entirely lost his voice. Those about him felt that he was injuring himself; but to all remonstrances he would only answer that the shepherd whose own the sheep are is ready to lay down his life for the flock. "Till then I cannot do too much." NeverI See Correspondence, vol. iv. 
theless, he was ready to listen to reason where the flock would not suffer; and in a letter from the Abbé de Fénelon to his cousin de Beaumont (the "Panta" of all this familiar correspondence) he mentions their uncle's health as tolerable, adding, that he is "moderating his work." In a note slipped in by the Archbishop an allusion is made to his stables,he had lost four good horses, and had nothing left but unsteady young horses, which shied and were all but useless. ${ }^{x}$ Probably these horses were the eventual cause of his death, for Saint Simon (to whom the Archbishop's last illness was announced by his nephew the Marquis) says, that while on a short visitation tour just before Christmas, Fénelon's carriage was upset in a dangerous place, ${ }^{2}$ and that although no one was hurt, the Archbishop saw the whole proceeding and the danger of his attendants, and that being already so fragile, he felt the shock of the

- Correspondcnce, vol. ii. p. 277.

2 It must have been of another accident that the Abbé Galet writes as happening in the autumn of $17 \mathrm{I} 4$, three months before Fénelon's death, when he was " nearly killed on a bridge crossing the river Somme. Some hours after, when I was speaking of the terror I had felt, he said, 'Bon, bon / what use am I of in this world? At all events, it is a great warning to be on the watch, since I might have died when least expecting it.' And thenceforward he had a special presentiment of death, and prepared more especially for eternity."-Vol. xi. p. Igo. 
accident very seriously, and returned to Cambrai much shaken. ${ }^{x}$

In the evening of January I, I 7 I 5 , he became seriously ill. Acute fever set in, accompanied by severe internal pain, for which the doctors could not account, but which one would think might easily have been accounted for by the recent upsetting of his carriage. ${ }^{2}$ The illness was short, for he died on the seventh day. Probably from the first Fénelon knew that this was his last illness, and that the journey of life was nearly ended for him, and he was all but "safe Home at last." Indeed, one of those in attendance on him, the Abbé Galet, says that Fénelon told him he felt he should not recover, and had only to prepare for immediate death. ${ }^{3}$

His last letters are full of cheerful, calm brightness. On December 28th he wrote concerning

I Mémoires, vol. xxii. p. 143.

2 De Ramsai says that Fénelon had inflammation of the lungs at this time.

3 Saint Simon, looking at Fénelon's end, as he looked at everything, through his intensely worldly, courtier-like spectacles, seems to wonder whether it was a love of fame, or disgust with the world, or " greatness of soul despising it," or genuine piety, which made the Archbishop "indifferent to all he was leaving, and entirely absorbed in what he was going to find : full of peace and tranquillity, which shut out all anxiety, while leaving ample room for penitence, detachment, and devoted care for the spiritual welfare of his diocese, and finally a trust which rose triumphant over all doubt and fear." 
various business matters to de Beaumont, expressing lovingly his hope soon to see him after his long absence, and quoting Horace :-

"A Abes jam nimium diu." x

A letter written on the same day to Mme. de Beauvilliers strikes one with the impression that Fénelon was already aware that his own end was very near. "I intreat you to let me hear of you," he says. "I am anxious about your health, which has been long and sorely tried. Moreover, when the heart is sick the whole body suffers. I dread the discussion of affairs for you, and all the things which will revive your grief. One must try to enter into God's plans, and help oneself to gain relief. We shall soon find again those whom we have really not lost. Day by day we get nearer and nearer to them by rapid strides. Yet a little while, and there will be no more cause to weep. It is we ourselves who are dying; those we love live to die no more. We all believe this, but our belief is imperfect: if it were thorough, we should feel concerning those dearest to us as Jesus Christ bade $\mathrm{His}$ disciples feel when $\mathrm{He}$ ascended into heaven, "If ye loved $\mathrm{Me}$, ye would rejoice because I go unto the Father.' Dut we mourn for ourselves when we weep for those dear ones we lose. One may well grieve for those who have

${ }^{2}$ Correspondence, vol. ii. p. 283 . 
led a worldly life; but in the case of a true friend of God, who has been faithful and lowly, one can think only of his happiness, and the graces he will win where he is for those he loves and has left behind. Suffer the Hand of God which has wounded you to soothe your grief. I am sure our dear one craves for your consolation, that he asks it of God, and that you will best enter into his mind by striving to control your grief." s

The same post carried one of Fénelon's affectionate letters to the Duc de Chaulnes, full of the fatherly admonitions he would never hear again - a letter which one would think the Duke must have prized beyond most things, and have read and re-read many a time. "Are you using your time as you know God requires you to do, and as you have promised Him you would do over and over again? Would you not be ashamed if you had failed to keep your word to the meanest of mankind as often as you have failed to keep it to God? You say that you love Him;-is it thus that one loves one's earthly friends, mere men like ourselves? Would you go on cheating them with continual, unavailing promises? Is it too much for God to require as much good faith and fulfilment of a promise as you expect your ploughboy to demand? But what will not men prefer to God!

'Correspondence, vol. i. p. $60 \mathrm{I}$. 
Wearisome, irksome details, employments which simply waste health, time spent for which one dare not attempt to give account, a je ne sais quoi which clouds your life, and lowers it in the world's sight,this is what you prefer to God! What a horrid bewitchment! Pray, humble yourself, in order to break the spell; ask God to set you free from the bonds of habit and taste which fetter you. Turn against yourself ; make a persistent, sustained fight ; mistrust the treachery of your natural disposition, the tyranny of custom, and the plausible pretexts with which we so ingeniously deceive ourselves. Listen to none of these-begin a new life; it will be hard at first, but God will help you, and you will soon taste the fruits. Happy he who trusts in God, not in himself. What would I not give to see you a new man! I ask it of God in this holy season, when we seek to be born anew with Jesus Christ. You can, you ought, you will have to answer for it to our Master. Accustom yourself, through recollection, to depend upon His Holy Spirit. With what zeal am I devoted to you !" etc. etc. ${ }^{x}$

But one letter later than this most characteristic note remains, and that in its own way is hardly less characteristic. It consists of a few lines written to the Marquis de Fénelon, and dated, "Saturday

× Correspondence, vol. i. p. 602. 
evening, Dec. 29, I 7 14," full of the endearments with which the Archbishop always addressed that cherished son of adoption, begging him to coax "Panta" to hasten back to Cambrai; and then, as if afraid of being selfish, adding, "Don't tease him; I don't want him for my own sake, but for his own. I know how to be happy alone, thank God." Then comes a request to the Marquis to bring his uncle the best edition of the Caracteres de la Bruyere, a recommendation to have further advice about his injured leg, and ending with "mille amitiés tendres au cher Put, ${ }^{x}$ qu'il me tarde d'embrasser tendrement. O que je t'embrasserai, mon petit Fanfan!" 2

That busy, graceful pen had finished its work. From the moment he had to yield to the pressure of illness on that evening of the Circumcision, Fénelon put aside everything save a calm, happy preparation for the great change he knew was at hand. So many years he had said with Job, "All my appointed days will I wait, until my change come," and now it was very nigh, even at the door.

The Archbishop would have nothing brought to

'M. Dupuy, one of the Duc de Bourgogne's household, who was included amongst Fénelon's friends who lost their offices for his sake. He is generally called Fut in Fénelon's intimate correspondence, as short for Putens, into which his friends had Latinized his name.

${ }^{2}$ Correspondence, vol. ii. p. 284 . 
his mind during those six days of dying but Holy Scripture, which he liked to have read continually to him. There was some idea on the part of his medical attendants that it was too great a strain on his attention (probably on account of the severe pain in his head); but he overruled them all, and found his greatest solace in death from the Book which had been his guide and stay through life. Over and over again, his chaplain tells us, they read S. Paul's words from 2 Cor. iv. and v. to him :-

"For which cause we faint not; but though our outward man perish, yet the inward man is renewed day by day.

"For our light affliction, which is but for a moment, worketh for us a far more exceeding and eternal weight of glory;

"While we look not at the things which are seen, but at the things which are not seen : for the things which are seen are temporal; but the things which are not seen are eternal.

"For we know that if our earthly house of this tabernacle were dissolved, we have a building of God, an house not made with hands, eternal in the heavens.

"For in this we groan, earnestly desiring to be clothed upon with our house which is from heaven:

"If so be that being clothed we shall not be found naked. 
"For we that are in this tabernacle do groan, being burdened: not for that we would be unclothed, but clothed upon, that mortality might be swallowed up of life.

"Now He that. hath wrought us for the selfsame thing is God, Who also hath given unto us the earnest of the Spirit.

"Therefore we are always confident, knowing that, whilst we are at home in the body, we are absent from the Lord:

" (For we walk by faith, not by sight:)

"We are confident, I say, and willing rather to be absent from the body, and to be present with the Lord.

"Wherefore we labour, that, whether present or absent, we may be accepted of Him."

"Repeat that passage again," the Archbishop would say.

From time to time important papers concerning urgent diocesan business were brought to him, and he signed them; and in compliance with a suggestion, he substituted the Abbé de Fénelon's name as an executor of his will for that of de Langeron, who had died since the will was made, and also answered certain questions as to some of his writings then in course of publication; but of his own accord he turned to no subject of worldly interest, and through 
the last two days and nights he was continually asking those around to repeat the special passages of Holy Scripture which were most adapted to his state. "Say those divine words again!" he often exclaimed; and then he would try to repeat them himself with a failing voice, while (so the bystanders said) his eyes and whole countenance were lit up with the bright expression of faith and love which the sacred words inspired. Several times he asked those around to repeat S. Martin's dying words, "Domine, si adhuc populo Tuo sum necessarius, non recuso laborem; fiat Voluntas Tua," and the antiphon which the Church has attached to them: " $\mathrm{O}$ virum ineffabile, nec labore victum, nec morte vincendum, qui nec mori timuit, nec vivere recusavit." s

Once his chaplain ventured to quote the first antiphon for S. Martin, to which these words are the answer, and wherein his disciples say, "Cur nos, Pater, deseris, aut cui nos desolatos relinquis? Invadent enim gregem tuum lupi rapaces." ${ }_{2}$ But the Archbishop only sighed. In his deep foresight he

I "Lord, if I am yet necessary to Thy people, I refuse not labour; Thy Will be done."

"O most worthy man, whom neither toil could weary, nor death vanquish, who neither feared to die, nor refused to live."

2 "Why dost thou forsake us, Father? and to whom dost thou leave us in our desolation? The ravening wolves will in. vade thy flock."-See Office for S. Martin's Day. 
felt that heavy clouds overhung his country and Church, and he knew that while he lay powerless there was One mighty to save.

On the second day of his illness he made his last confession (he had made his confession as usual on Christmas Eve, before saying midnight Mass); and early on the morning of January $4^{\text {th }}$ he asked his chaplain for the Viaticum. An hour later he again asked if everything was ready for that solemn act. The chaplain replied that he was scarcely in sufficient danger to need urgent haste. "In the state in which I feel myself to be nothing can be more urgent," he answered.

The Blessed Sacrament was brought almost immediately after this, Fénelon causing himself to be carried out of the little room (la petite chambre grise) in which he habitually slept, to the large state bedroom mentioned before, where he frequently sat. This was in order to have room for his chapter and others, whom he wished to assist at the last great religious act of his life; and before receiving the Viaticum he spoke a few words of tender exhortation to those around.

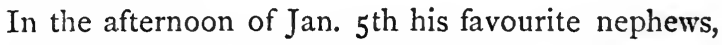
the Abbé de Beaumont and the Marquis de Fénelon, arrived at Cambrai. Saint Simon describes the sudden appearance of the latter at his house, with the 
tidings of his uncle's dangerous illness, asking the Marquis de Saint Simon to get leave from the Duke of Orléans for his physician Chirac, one of the most eminent medical men in France, to go with him at once to Cambrai, and borrowing Saint Simon's travelling carriage, in which they set out within an hour from that time. ${ }^{x}$ The Archbishop showed great satisfaction when he saw his nephews, and asked who had given them the alarm. They could not speak for emotion, and could only point to de Fénelon's younger brother, the Abbé, who was present. Chirac tried the usual strong treatment of that period-more bleeding and emetics, which could not relieve the patient, and probably hastened his end. He submitted to all patiently and cheerfully, and those who knew his tenderness of heart, and how he had suffered in the parting from de Langeron and other friends, were surprised to see him calm and unagitated while witnessing the irrepressible grief of the nephews who were as sons to him.

On the Epiphany he expressed regret that he was too weak to say Mass himself, and bade his chaplain go to say it on his behalf. During that short. interval he grew so much feebler that Extreme Unction was given. Directly afterwards he bade every one save his chaplain leave the room, and then

'Mémoires, vol. xxii. p. 134 . 
dictated to him a few lines addressed to Père Le Tellier, the King's Confessor. These were as follows:-

$$
\text { "CAMrRai, Fan. 6, I7I5. }
$$

"I have just received Extreme Unction, and it is in this condition, reverend Father, when making ready to appear before God, that I earnestly beseech you to lay my true mind before the King. I have never felt aught save docility to the Church, and abhorrence of the novelties attributed to me. I accepted the condemnation of my book with the most absolute unreserve. There never was a moment in my life when I did not entertain the liveliest gratitude and most honest zeal for the King's person, as also the most inviolable respect and attachment.

"I take the liberty of asking of his Majesty two favours, which have no concern with me or mine. First, that he will vouchsafe to appoint a successor ${ }^{x}$ who is pious, worthy, orthodox, and firm against Jansenism, which is very much in vogue on this

' Louis XIV., who survived Fénelon eight months, never appointed any successor. In 1716 the Regent Duke of Orleans appointed the Abbé d'Estrées, who died in 1718 , without having been consecrated. Apropos of this fact, Saint Simon mentions a curious prophecy that he would have three successors who would never take their seat at Cambrai :-“'L'Abbé d'Estrées eut Cambrai. Je me souviens très-bien qu'à la mort du célèbre Fénelon, son prédécesseur, il courut une prophetie de je ne sais qui de ce diocèse, que ses trois premiers successeurs n'y entreraient jamais."-Mémoires, vol. xxvi. p. 27. 
frontier. And next, that he will kindly complete under my successor that which could not be completed under me as to the Community of Saint Sulpice. I owe to his Majesty the help that Community has rendered me. Nothing can be more apostolic or venerable; and if his Majesty will intimate to my successor that he would do well to conclude the arrangement with them which is already so forward the matter will soon be accomplished. I wish long life to his Majesty, of whom both Church and State have so great a need. If it be permitted me to come before the Presence of God, I will continually ask this of Him. You know, reverend Father, with what veneration $\mathrm{I}$ am, etc. etc.

"FN., Archbishop of Cambrai." x

The rest of that day and the night following were very full of pain, but Fénelon was able to soothe his sufferings by uniting them to those of his Dear Lord. "I am on the Cross with Christ" ("Christo confixus sum cruci"), he said. Then those he loved who stood around repeated in his dying ear the assurance, that "the sufferings of the present time are not worthy to be compared with the glory which shall be revealed."

As his agony increased, they reminded him how 'Correspondence, vol. iv. p. 595. 
S. Luke records that in Gethsemane our Lord prayed ever more and more earnestly: "Factus in agonia prolixius orabat."

“Three times He prayed the same prayer," Fénelon said-“"Oravit tertio eumdem sermonem dicens;" . . . but here the pain cut short his words, and the bystanders continued them:- " Father, if it be possible, let this cup pass from Me; nevertheless, not as I will, but as Thou wilt."

"Yes, Lord," the Archbishop murmured, taking up their words with a feeble, broken voice, "Thy Will, not mine."

Between fever and weakness occasional delirium came on, of which Fénelon was conscious, and he seemed distressed lest any unseemly or impatient words should escape him against his will. But nothing of the sort occurred; and as the paroxysms passed away, he would clasp his hands fervently, and lift his eyes upwards, as though in close communion with God.

All through that last night he was surrounded by those who loved him best : his nephews, Pantaléon de Beaumont, (the Abbé) Gabriel, the soldier Marquis, François (Abbé de Fénelon); the young Chevaliers Henri, Alexis, and Jacques; the two brothers l'Eschelle, both dear friends of his Preceptor days, and attached to the Duc de Bourgogne's household; and sundry 
others. All of these profited by the intervals of ease which came to ask a last blessing; as did his whole household, weeping and lamenting the master they could not but love so well. Many persons out of the town who had been under his direction obtained admittance to the death-chamber for the same purpose ; and the Superior of Fénelon's Seminary (a Saint Sulpicien, Le Vayer by name), who remained with him all that night, received his special blessing for the Seminary and the whole diocese. It was this priest who said the last prayers for the dying, and continued to pray and repeat brief passages of Holy Scripture through the last moments; amid which, after about half an hour of seeming unconsciousness, the Archbishop passed gently away, at a quarter-past five on the early morning of January 17,17 I 5 .

So ended a life of unchanging love and union with God; or, should one not rather say, so it was merged into the real life of Love and Union with God for which all here had been but a making ready, - the preparation of the mortal to put on that immortality the thought of which had ever been before Fénelon's eyes and ruled his acts and thoughts.

"The death of this great Bishop at sixty-five, sustained with the Sacraments of the Church, surrounded by his family and clergy, could not but be a great 
lesson to those who survived, and full of hope for him who was called." So says Saint Simon ; ${ }^{x}$ and, after alluding to the sorrow and consternation generally felt through Flanders at Fénelon's death, he goes on to remark, what must have astonished the worldly-wise courtier, that "all M. de Cambrai's affairs were in such perfect order that he neither owed nor left behind him a sou."

Fénelon's will is dated May 5, I705. It begins by saying:- "Though my health is as good as usual, I wish to prepare for death, and with this view I write this present will with my own hand." He then reaffirms his position with respect to his book and the errors imputed to him, and his entire submission in the matter of his condemnation, adding that he had cherished no thought concerning those who attacked him, save in sincere prayer for them, and in desiring to. abide in brotherly love with them. There were certain legacies to his servants, and then he directs:"I wish my burial to be in the metropolitical church of Cambrai, as simple as may be and with the least possible expenditure. This is not a mere conventional expression of humility, but because I think the money laid out on funerals other than simple had better be kept for more useful purposes; and also I think the modesty of a Bishop's funeral should set the example to the × Mémoires, vol. xxii. p. 144 . 
laity, and lead them to diminish the useless outlay in their burial arrangements."

Fénelon goes on to nominate his nephew the Abbé de Beaumont ("who has been to me all his life as the best of sons to a father") as his residuary legatee, giving him no special directions, but leaving to him, with perfect confidence, the disposal of whatever possessions might be found.

He named de Chanterac ("my counsellor in this diocese, whose friendship has been proof against every trial, and for whom I have a great veneration ") and de Langeron ("the precious friend whorn God gave me while we were yet both young, and who has been one of the greatest comforts of my life") as his executors.

The last clause says:-- "While I love my family deeply, and am aware of the needy state of their affairs, I do not think it right to leave anything to them. Ecclesiastical property is not meant to supply family wants, and ought not to pass out of the hands of 'those who minister in the Church. I trust that God will bless the nephews I have educated, and love dearly, by reason of the uprightness and religion in which they seem to me to be confirmed."

According to the Archbishop's express commands, his letter to Père L.e Tellier was sent off immediately that he was dead, and was doubtless speedily laid by 
him before the King. Of what Louis XIV.'s feelings may have been in reading it we have no record. The Marquis de Fénelon, in a brief sketch of his uncle's life, says that on hearing of the Archbishop's death, Louis XIV. exclaimed bitterly, "Il nous manque bien au besoin !" Mme. de Maintenon alludes coldly enough to it in a letter to the Curé de Saint Sulpice. Saint Simon speaks of the Archbishop's letter as dignified and touching in a way which probably indicates the general feeling concerning it at Court. Little enough it signified to him who wrote it what reception his parting words might meet with. To few could S. Paul's words have come home with more force :- "With me it is a very small thing that $I$ should be judged of you, or of man's judgment: yea, I judge not mine own self ... but $\mathrm{He}$ that judgeth me is the Lord ... Who both will bring to light the hidden things of darkness, and will make manifest the counsels of the hearts: and then shall every man have praise of God " ( $r$ Cor. iv. $3-5)$.

Warm and well-deserved regrets for their Archbishop were expressed by the Chapter of Cambrai ; but it is noticeable that they threw on the executors (de Chanterac and the Abbé de Fénelon) the responsibility of deciding whether it were expedient to pronounce the customary oraison funebre over him, a hesitation probably arising from the fear of displeasing 
the King. Those who knew Fénelon's mind best had no hesitation in dispensing at once with a ceremony which they no doubt rightly felt could add no lustre or grace to the memory of one who was'certain to live in the hearts of those of his own time, and in the future history of the Church through his own merits, better than through any oratory, however eloquent or well conceived. So Fénelon was the only Archbishop of Cambrai who was laid in the grave without a funeral oration; and it was also remarked that in the Académie Française, neither Dacier the Directeur, nor de Boze, Fénelon's successor, dared mention Télémaque, albeit in those days considered as one of the greatest chefs-d'cuvre of literature.

Cardinal Quirini stated that Pope Clement XI. wept when he heard that the Archbishop of Cambrai was dead, partly for the Church's loss, and partly for his own weakness in not having carried out his wish to make Fénelon a Cardinal, because of his fe:rr to offend Louis XIV.

The King never made the least expression of interest or sympathy fo: any of Fénelon's family, although one might have thought that when the Archbishop himself and the Duc de Bourgogne had both passed beyond the reach of his jealousy, it would have been a graceful act, reflecting more credit upon the King than any one else, had he made some 
reparation for long years of unkindness and petty revenge.

In 17 16, the Duke of Orléans appointed de Beaumont to the Bishopric of Saintes; Saint Simon says at his suggestion, not from any personal friendship, but because de Beaumont was a worthy man, who had been about the Princes, and a nephew of Fénelon's; above all, out of affection for the Duc de Beauvilliers' memory. ${ }^{x}$

Fénelon was laid to rest, then, as he had desired, in all simplicity and without ostentation, beneath the High Altar of his Cathedral; nor was it till 1724 that his nephew the Marquis placed an inscription to him in the Cathedral of Cambrai, written by a Jesuit Father Sanadon, in the somewhat pompous, ponderous style that was popular at that day, and which we may be excused for repeating here.

In I 793, during the mad fury of the Revolution, the Cathedral was destroyed, and Fénelon's tomb was torn up, and the popular idea is that the body was thrown aside, and the leaden coffin melted into bullets. But this was not the case. There are official documents describing the finding of the body by the Mayor of Cambrai, the leaden coffin being unsoldered and damaged, the wooden one within in a state of decomposition. The skull was found I Mémoires, vol. xxvi. p. 28. 
whole, many of the bones, and a white silk tunicle and cincture much decayed, and near, the broken fragments of a monumental stone bearing the inscription-

\section{"HIC JACET}

Franciscus De Salignac de la Mothe de Fénelon, Archiepiscopus Cameracensis, Defunctus die septima JANUARII 17I5; E PRIORI TUMULO TRANSLATUS Dí 28 MARTII I720."

These remains were reverently sealed up, and replaced in a vault, until in the year $\mathbf{I} 2$ of the Republic (A.D. I 800 ), it being discovered that the coffin was suffering from damp, and there being no proper place on the site of the old Cathedral for the preservation of the body, it was removed by the Mayor and Commissary of Police to the Oratory of the "Maison de Vanderburch" until a fitting resting-place should be prepared. There is an arrêt issued $2 \mathrm{I}$ Thermidor, An 12, by the Préfet of the Department du Nord, in consequence of the Emperor's orders that "a monument or mausoleum be erected to receive the ashes of the immortal Fénelon," to which they were to be transferred in due time.

It does not seem as if this had been carried out, as the existing monument to Fénelon is in the new Cathedral (a poor modern church), of the date of I 825 . 
But the noblest monument to Fénelon's memory will ever be the veneration and affection felt for him by the whole of Christ's Church, and the gratitude of many souls helped on their heavenward journey by his graceful, albeit stringent words.

"How is he numbered among the children of God, and his lot is among the saints!" (Wisd. v. 5.) 


\section{$I N D E X$.}

ACADÉmieFrançaise, Fénelon chosen a member of, 75 .

Aguesseau, D', 14I, 180, 2ro, 240, 247.

Albani, Cardinal, 222, 243.

Albert, Chevalier de, death of, 307 .

Anjou, Duc d', 7 r.

Assembly of Clergy at Saint Germain-en-Laye, 250.

Beaumont, De, 40, r93, 287, 465, 468 ; letters to, $297,362,391-395$, $440,444,45 \mathrm{x}$.

Beauvilliers, Duc de, letters to, 12, r73, $175,179,233,306,320,321$, $350,415,432$; letters from, 152 ; character of, 32,85 ; Duc de, 172 ; death of, 439 .

Beauvilliers, Duchesse de, 433, 440, 451.

Berri, Duc de, 72.

Bossuet, 15, 84, 101, 105, rog, 133, $153,159,170,18 \mathrm{r}, 197,208,25 \mathrm{r}$, 293 ; letters to, $27,13^{8}$; letters from, 35 ; answer to, 203 .

Bossuet, Jacques, 132, 135, 184, 192, 204, 209, 225.

Bouillon, Cardinal de, 182, 208, 225.

Bourdaloue, 75,96 .

Bourgogne, Duc de, childish character, 45; grief at Fénelon's exile, 171 ; letters to Fénelon, 26r, 316, $328,329,330,342,346$; from Fénelon, $263,266,272,336,337$, $344,346,399,415$; meetings at Cambrai, 315, 319, 329 ; recalled from Flanders, 319; character, 321 ; Saint Simon's views of, 324; sent to the German campaign, 327 ; campaign of 1708,331 ; cabal against, at Court, 354 ; succeeds his father as Dauphin, 390 ; credit at Court, 405 ; warned against poison, 400 ; sickens, 412; death, 4r3; papers left, 421.

Bretagne, Duc de, death of, 414 .

Brief of Condemnation issued, 225 ; how received in France, 244.

Brisacier, De, letter from, 143 ; letber to, 169 .

Cambrat, appointment to, 105 ; fire at, 142 ; Fénelon retires to, 170 ; life at, 275, 277, 408 .

Carenac, Priory of, 16 .

Cas de Conscience, 429.

Casanata, Cardinal, $135,225$.

Chanterac, De, 182, 205, 218, 296, 465 ; letters from, $147,188,190$, $196 ; 200,205,207,226$; letters to, 164, 184, 189, 191, 195, 199, $208,220,230,237,248$.

Chaulnes, Duc de, 42x, 434, 439, 452 ; character of his sons, 436 .

Chevremont, De, letter from Fénelon, 249.

Chevreuse, Duc de, 33, $13^{8}, 151$, $307,311,356,396,399,407,408$; letters to, $308,309,318,350,40 x$, $405,406,418,430$; death of, $43^{2}$.

Chevry, Mme. de, 443.

Coadjutor, need of, 444 .

Colloredo, Cardinal, 155.

Combe, Père La, 88

Condé, Grand, 4 .

Congregation, Extraordinary, of Cardinals, 223 .

Consecration, rog.

DAUPhIN, death of, 397 .

Dauphine, the, last illness and death 4 ro.

Death, 463.

Dialogues des Morts, 70 . 
Dialogues sur l'Éloquence, 301.

Directions pour la Conscience d'un Roi, 423.

Education, plan of the Duc de Bourgogne's, 66.

Eugene, Prince, respect for Fénelon, 275.

Fantasque, le, 50 .

Fénelon, Antoine de, 3-6; death of, I9.

Fénelon, Archbishop, portrait by

Saint Simon, 42, 276; by D'Aguesseau, 43; appointed Preceptor to the Duc de Bourgogne, 34; Archbishop of Cambrai, 105; dismissal of friends, 193; appeal to Rome, 153; reply to the Rélation, 204; final dismissal, 217 ; receives tidings of condemnation, 229; letter to Mgr. d'Arras, 235; daily life described by Le-Dieu, 284; dress, etc., 283; habitual temperance, 287 ; unremitting labour, 299; interview with the Duc de Bourgogne, 318 .

Fénelon, Marquis de, 356 ; letters to, $357,359,363,365-383,386$, 387-390, 44I, 453.

Fleury, 15, 25, 40, 193; character of the Duc de Bourgogne, 57.

Fontaine, La, 56.

Gamaches, Mme. de, letter to, 177 .

Godet-des-Marais, Bishop of Chartres, 75, 93, 157, 244, 255 .

Guyon, Mme., 87, 114, I17, 126, 130 ; letters from, 100.

HARLAY, De, Archbishop, 6, 15, 29, 112 ; opposition to Mme. Guyon, 89.

IlLNess, last, 450 .

Innocent XII., 183, 188, 190, 196, 201, 205, 211, 2I7, 218, 242.

Issy Conferences, ro3.

Joseph, Emperor, death of, 397.

KING, the, letters to, $15^{8}$; letters to the Pope, 165, 216; dismissal of Fénelon, 217; menaces the Pope, 224 ; last messages to the, 460 .
Knox, Alexander, criticisms on Fénelon, 384 .

LAMI, Père, 25I, 428, 430.

Langeron, 15, 24, 40, 193, 430.

Languet, Curé of St. Sulpice, 12.

Laval, Marquise de, letters to, 16, $18,35,72,74$.

Le-Dieu, Abbé, 226, 259 ; visit to Cambrai, 281.

Le Tellier, Archbishop of Rheims, ro7.

Le Tellier, Père, last letter to, 460 , 465.

Louis, S., character of, 272.

Maintenon, Mme. de, 33, 75, 14 I, I $48,165,166,197,254$; letters to, $76,124,127,165,212$; letters from, 94, 95, 100, 101, Ir3, Ir4, II6, 140, 151, 422 .

Maisonfort, Mme. de, 90, 94, 152 ; letter to, ro2.

Mandement on his condemnation, 238.

Marlborough, Duke of, generous conduct, 355 .

Martin, S., quotes, 457.

Martineau, Père, letter to, 424 .

Maximes des Saints, $134,138,142$ $147,154,156,210,221$; censure by the Sorbonne Doctors, 216; condemned at Rome, 225.

Miramion, Mme. de, 90.

Missions of Poitou and Saintonge, 24.

Molinos, 86.

Montfort, Duc de, killed, $31 x$.

Moyen Court, the, $96,98,100$.

Munich, Marshal, 428.

Noailles, De, Bishop of Châlons, 96, 104, 207, 254, 429, 430; appointed Archbishop, $\mathbf{1 1 3}_{3}$; letters from Fénelon, 136, 160, 164 ; letters to Mme. de Maintenon, 149; Pastoral Instruction, I92.

Noailles, De, and Quesnel, 447.

Olier, M., 4, ro.

Omer, Saint, Bishop of, 246

Orléans, Duke of, 425,468 .

Oudenarde, battle of, 332 .

PARIS Assembly, 245.

Pastoral work, 305. 
Pirot, Dr., 137, 216.

Pope Innocent XII., appeal to, 153.

Preaching, Fénelon's, 300.

Preceptorship, appointmont to, 34 .

Quietism, 86; false accusation of, in later life, $3^{8} 4$.

RAmSAI, De, 426; reception at Oxford, 428 .

Rancé, De, letter to, 148.

Religious Houses, advice to, 298.

SACRAments, Last, 459.

Salignac, Abbé de, letters to, 362, $390,391$.

Salignac de Fénelon, family, 2.

Sarlat, Bishop of, 7, II.

Seignelai, Marquis de, letters to, $25,27$.

Seminary at Cambrai, 294, 298, 463.
Serry, Père, letters from, 185 .

Sulpice, Saint, 7, 294, 295.

TÉlEMAQUE, 256; treacherously published, 258; not intended as a satire, $26 \mathrm{r}$.

Traité de l'Éducation des Filles, 20; du Ministère des Pasteurs, 23.

Treatise on the Existence of God, 426.

Tronson, 6, 157; letters from, 8, 36 , 294 ; letters to, from Fénelon, I18, 137, I68, 294; from de Beauvilliers, 122.

Vendôme, Duc de, 33r.

Voltaire, remarks on Fénelon, 284.

Voysin, Secretary of State, letter to, 443.

WiLL, altered, 456; substance of, 464 . 



\section{ICtorks by the autbor of " $\mathfrak{a}$ Dominican artist," $\mathfrak{t}$.}

\section{BOSSUET AND HIS CONTEMPORA- RIES. Crown 8vo. I2s.}

\section{OPINIONS OF THE PRESS.}

"In the ten chapters that compose the work we have a rapid yet complete sketch of the life of Bossuet, accompanied by short and generally judicious criticisms of his works, which are arranged in chronological order, and thus play the part they ought to play in the biography of a man whose writings were his deeds."-Athenaum.

"We are always glad to welcome a fresh work from the graceful pen of the author of 'A Dominican Artist.' And the fact that not only is there no popular Life of Bossuet to be found in France, as we are told in the preface, but, so far as we are aware, no Life of him at all in English, gives an additional interest to the present volume."-Saturday Review.

"It contains so many interesting facts, that it may be profitably read even by those who already know the man and the period." - Spectator.

"Bossuet's daily life, his style of preaching, his association with the stirring political, social, and ecclesiastical events of his time, are presented in a simple but picturesque way, which will render the book acceptable far beyond the circle of those who occupy themselves specially with theological studies." -Daily News.

"Here is a clear and good work, the product of thorough industry and of honest mind."-Nonconformist.

"All biography is delightful, and this story of Bossuet is eminently so." - Notes and Queries.

"Should be read widely." $\rightarrow$ scotsman.

"As a chronicle of Church life in France at an eventful period it is invaluable."-Fohn Bull.

"The history of his life is well told in the pages before us. . . . The book may be read with interest and profit by those who wish to study the religious characteristics of the I6th and 17 th centuries, both Roman and Protestant."-Rock.

"The book is in every sense well done, accurate, interesting, and concise, doing full justice to the great merits of its hero, and yet rarely erring on the side of excessive partiality." - Scottish Guardian.

". . . The admirers of the great bishop will find in the new English biography a condensation of all the minutest details which are known about nim, and which are spread in other works through numerous volumes. The tone of the work is agreeable, and not too florid. It is an historical study rather than a panegyric, and, notwithstanding the character of many theo'ogical questions, may be read without fatigue."-The Nation (New York).

"Much useful historical matter is presented in this volume in an effective manner, and it affords striking glimpses of the ecclesiastical 'situation' in France in the reign of Louis XIV."-Literary World (Boston).

"Is complete in all that is necessary to convey a uniform history of the time, and of the character of the subject of the memoir."-New York Times.

"Une biographie générale et complète, puisée aux meilleures sources, et toujours appuyée soit sur les œuvres mếme du grand évêque, soit sur les némoires contemporains, soit sur les jugements des critiques modernes les plus autorisés. ..... C'est là un bon livre longuement méditê, et qui ferait honneur à l'un de nos plus sérieux érudits."-Polybiblion (Paris). 


\section{A CHRISTIAN PAINTER OF THE NINETEENTH CENTURY. Being the Life of Hippolyte Flandrin. Crown 8vo. 7s. 6d.}

\section{OPINIONS OF THE PRESS.}

" A bright and vivid sketch of the painter to whose artistic skill and Christian feeling modern Paris owes exquisite adornments. . . . . It is worth reading as an example of quiet, stedfast heroism in pursuit of a worthy object."-Literary Churchman.

"As charming and interesting as all the author's previous books have been. .... One of the most striking features in this book is the touching insight we gain from its pages into French family life."-Church Herald.

"L'auteur anglais a traduit, avec une profonde connaissance des deux langues, ces lettres intimes du grand artiste que nous connaissions déjà, et a complété sa biographie par des détails nouveaux et curieux sur les années qu'il a passées à Rome. On peut prédire au traducteur, pour son nouveau livre, le succès de ses précédents ouvrages, A Dominican Artist, S. Francis de Sales, etc., dont plusieurs éditions ont été épuisées."-Gazette des BeauxArts (Paris).

"This is a charming addition to biographical literature."-Notes and Queries.

"The life of this admirable artist and true Christian has now been written by a practised and skilful hand; and so graceful a memoir cannot but prove acceptable to all lovers of art."-Scottish Guardian.

"It is a book which any young person may read with equal pleasure and profit."-Church Review.

"Will be pleasant reading to many besides those interested in that school of French art of which Flandrin was one of the most distinguished exponents." -Scotsman.

"A good man and a great artist."-Standard.

"A charming book."-Nationai Church.

\section{THE REVIVAL OF PRIESTLY LIFE IN THE SEVENTEENTH CENTURY IN FRANCE. A Sketch. Crown 8vo. 9 s.}

\section{OPINIONS OF THE PRESS.}

"It serves incidentally to throw a good deak of light on the condition of the Fronch Church in the sixteenth and seventeenth centuries, and the w ty in which it was influenced by the counter Reformation which did so much to change the inward and outward life of Catholicism throughout Europe." -Saturday Review.

"No Christian, to whatever denomination he may belong, can read without quick sympathy and emotion, these touching sketches of the early Oratorians and the Lazarists, whose devọtion we can all admire."-Standard.

"It merits to be read by every Priest and by all who have the care of training souls for the Priesthood; while its attractive style will win for it a much wider class of readers."-Church Times. 


\section{THE HIDDEN LIFE OF THE SOUL. Small 8vo. 2s. $6 d$.}

\section{OPINIONS OF THE PRESS.}

"'The Hidden Life of the Soul,' by the author of 'A Dominican Artist,' is from the writings of Father Grou, a French refugee priest of $\mathrm{r}_{792}$, who died at Lulworth. It well deserves the character given it of being 'earnest and sober,' and not 'sensational.' "-Guardian.

" Between fifty and sixty short readings on spiritual subjects, exquisitely expressed, and not merely exquisite in expression, but presenting a rare combination of spiritual depth, and of strong practical common sense. We have read carefully a large number of them, for, after reading a few as texts, we could not lay it down without going much further than was sufficient for the mere purpose of reporting on the book. The author was one Père Grou, a native of Calais, born in $\mathbf{I 7 3} \mathrm{I}$, who in $\mathbf{1 7 9 2}$ found an asylum from the troubles of the French Revolution at Lulworth Castle, known doubtless to many of our readers as the ancestral home of the old Roman Catholic family of Weld, where he died in 1803 . There is a wonderful charm about these readings - so calm, so true, so thoroughly Christian. We do not know where they would come amiss."-Literary Churchman.

\section{THE LIGHT OF THE CONSCIENCE.}

With an Introduction by the Rev. T. T. CARTER, M.A., Rector of Clewer, Berks. Crown 8vo. $5 s$.

$$
\text { CONTENTS. }
$$

Light is Love-Recollection-Prayer-Meditation-Ejaculatory PrayerParticular Self-Examination - Holy Communion-Confession-Spiritual Reading-Common Faults-Irritability-Calmness-Family Life-Contradiction-Sensitiveness-Decision-A Busy Life-Rule of Life-RetreatsSuggestions for a Retreat-The Privilege of Suffering-Cheerfulness-Order and Quiet in Daily Life-Inward Difficulties-Fretfulness-Faith-The Profitable Use of Faults-Single-Mindedness-The Presence of GodResolution-Common Things-Humility-Self-Renunciation-The Interior Life.

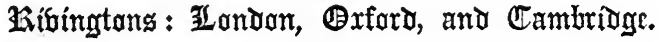




\section{S. FRANCIS DE SALES, BISHOP AND PRINCB of Geneva. Crown 8vo. $6 s$.}

\section{OPINIONS O.F THE PRESS.}

"To those who have read thi previous works by the author of this 'Life of S. Francis de Sales,' it is unnecessary for us to say a word in commendation of the present volume. It is written with the delicacy, freshness, and absence of all affectation which characterised the former works by the same hand, and which render these books such very much more pleasant reading than are religious biographies in general. The character of S. Francis de Sales, Bishop of Geneva, is a charming one; a more simple, pure, and pious life it would be difficult to conceive. His unaffected humility, his freedom from dogmatism in an age when dogma was placed above religion, his freedom from bigotry in an age of persecution, were alike admirable."-Standard.

"We are delighted to receive this charming biography, and still more delighted to learn that it will shortly' be followed by a translation of his 'Spiritual Letters.' What is here given is a portrait of the Saint in hinself rather than of the Bishop in his work, and a most exquisite and winning portrait it is, though of course as it cannot avoid showing at least the principles on which his work was carried out, so neither can it avoid abundant illustrations of them. from his actual labours. And. indeed, it is just in this that we think the great beauty of the book lies; and we must congratulate its readers on the felicity with which the writer has managed the not very easy task of balancing the space given to the inner portraiture with that devoted to illustrations of its several features drawn from outward work and activity. The result is a most enjoyable and readable book, thoroughly natural, with nothing strained or forced about it."-Literary Churchman.

"We can bear our willing testimony to the beautiful picture which is given us in this 'Life of S. Francis de Sales.' The writer has evidently studied carefully the best biographies of the Saint, has visited the Convent of the Visitation at Annecy, seen its precious relics, and conversed with the Sisters who still occupy the cradle of their Order."-Tablet. 


\section{THE SPIRIT OF S. FR ANCIS DE SALES. \\ Translated from the French. Crown 8vo. $6 s$.}

\section{OPINIONS OF THE PRESS.}

"S. Francis de Sales, as shown to us by the Bishop of Belley, was clearly as bright and lively a companion as many a sinner of witty reputation. He was a student of human nature on the highest grounds, but he used his knowledge for amusement as well as edification. Naturally we learn this from one of his male friends rather than from his female adorers. This friend is Jean-Pierre Camus, Bishop of Belley, author, we are told, of two hundred books-one only however still known to fame, the Spirit of S. Francis de Sales, which has fairly earned him the title of the ecclesiastical Boswell." - Saturday Review.

\section{THE SPIRITUAL LETTERS OF $S$. FRANCIS DE SALES. Translated from the French. Crown 8vo. 6s.}

\section{OPINIONS OF THE PRESS.}

" The letters are addressed to people of all sorts : to men and to women, to laity and to ecclesiastics, to people living in the world or at court, and to the inmates of Religious Houses. And what an idea it gives one of the widely ramifying influence of one good man and of the untiring diligence of a man who, in spite of all his external duties, could find or make the time for all these letters. - . For they are not merely wise and true in their general counsels, but are distinguished for the number and variety of sparkling dicta, telling bits of metaphor, parable, or analogy; the very things which in the day of commonplace books would have been seized upon for trarscription, as nuggets of beauty shining out from a mass which is auriferous throughout."-Literary Churchman.

"There are a hundred and fifty-nine letters in all, and there are few, if any, amongst them which will not be found suited to the wants of religious persons at the present day."-Church Times.

"We strongly recommend the book to our readers."-Church Builder.

Laíningtons: Zllandon, Oxford, and Cambrioge. 


\section{BY THE SAME AUTHOR.}

\section{A DOMINICAN ARTIST; A SkETCh OF THE}

Life of the Rev. PÈre Besson, OF the ORder of ST. Dominic. Crown 8vo. $6 s$.

\section{OPINIONS OF THE PRESS.}

"The Author of the life of Père Besson writes with a grace and refinement of devotional feeling peculiarly suited to a subject-matter which suffers beyond most others from any coarseness of touch. It would be difficult to find ' the simplicity and purity of a holy life ' more exquisitely illustrated than in Father Besson's career, both before and after his joining the Dominican Order under the auspices of Lacordaire. - . Certainly we have never come across what could more strictly be termed in the truest sense ' the life of a beautiful soul.' The Author has done well in presenting to English readers this singularly graceful biography, in which all who can appreciate genuine simplicity and nobleness of Christian character, will find much to admire and little or nothing to condemn." Saturday Review.

"It would indeed have been a deplorable omission had so exquisite a biography been by any neglect lost to English readers, and had a character so perfect in its simple and complete devotion been withheld from our admiration. . . . But we have dwelt too long already on this fascinating book, and must now leave it to our readers."-Literary Churchman.

"A beautiful and most interesting sketch of the late Père Besson, an artist who forsook the easel for the Altar."-Church Times.

"A book which is as pleasant for reading as it is profitable for meditation." - Union Review.

"We are indebted to the graceful pen of the translator of Madame Louise de France for another Catholic Life, beautifully written, and full of the spirit of love."-Tablet. 


Mrs Henrietta Louisa

(Farrer)

$P Q$ rnak

Fenelon

. $\mathrm{I}_{4}$. 
